
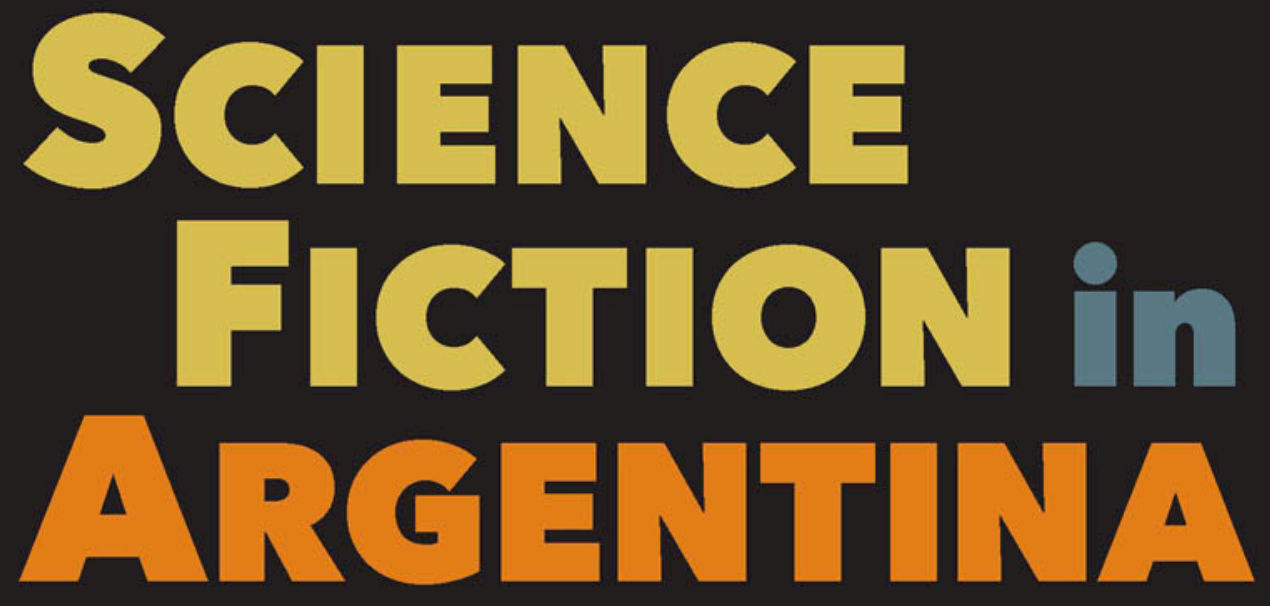

\title{
Technologies of the Text in a Material Multiverse
}

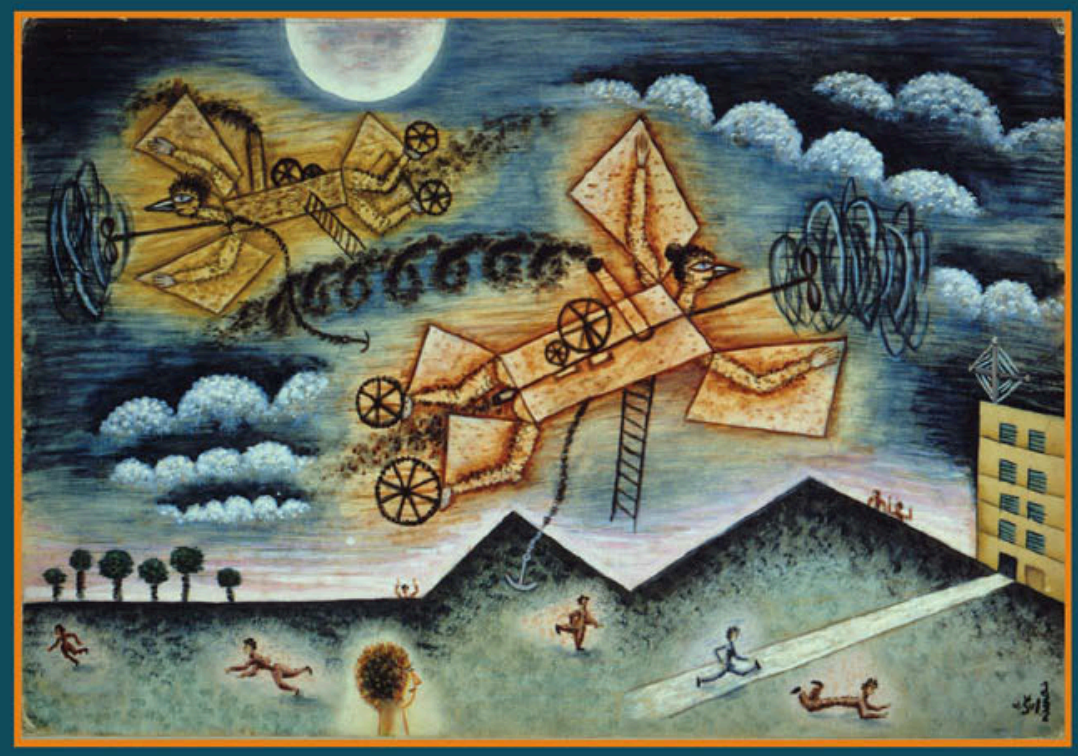

Joanna page 
Science Fiction in Argentina 
digitalculturebooks, an imprint of the University of Michigan Press, is dedicated to publishing work in new media studies and the emerging field of digital humanities. 


\section{Science Fiction in Argentina}

Technologies of the Text in a

Material Multiverse

Joanna Page

University of Michigan Press

Ann Arbor 
Copyright (C) 2016 by Joanna Page

Some rights reserved

\section{ccreative}

This work is licensed under the Creative Commons Attribution-

Noncommercial-No Derivative Works 3.0 United States License. To view a copy of this license, visit http://creativecommons.org/licenses/by-nc-nd/3.0/ or send a letter to Creative Commons, I7I Second Street, Suite 300, San Francisco, California, 94105, USA.

Published in the United States of America by the University of Michigan Press Manufactured in the United States of America

(0) Printed on acid-free paper

$2019 \quad 2018 \quad 2017 \quad 2016 \quad 4 \quad 3 \quad 2 \quad$ I

A CIP catalog record for this book is available from the British Library.

Library of Congress Cataloging-in-Publication Data

Names: Page, Joanna, 1974- author.

Title: Science fiction in Argentina : technologies of the text in a material multiverse / Joanna Page.

Description: Ann Arbor : University of Michigan Press, [20I6] | Includes bibliographical references and index.

Identifiers: LCCN 20I504453I| ISBN 9780472073IO8 (hardback : acid-free paper) | ISBN 9780472053100 (paperback : acid-free paper) | ISBN 9780472121878 (e-book)

Subjects: LCSH: Science fiction, Argentine-History and criticism. | Literature and technology-Argentina. | Fantasy fiction, Argentine-History and criticism. | BISAC: LITERARY CRITICISM / Science Fiction \& Fantasy. | LITERARY CRITICISM / Caribbean \& Latin American.

Classification: LCC PQ7707.S34 P34 2016 | DDC 860.9/35882-dc23

LC record available at http://lccn.loc.gov/2015044531

http://dx.doi.org/10.3998/dcbooks.13607062.0001.001 
To my brother,

who came into this world to disrupt my neat ordering of it, a talent I now admire. 
The entire soul, then, must consist of tiny atoms, strung out through sinews, vitals, veins.

-Lucretius, On the Nature of Things 


\section{Acknowledgments}

Parts of this book were written during a period of extended research leave in 20I2, funded by the British Academy, and I am extremely grateful for the peaceful and productive time this afforded me. Research trips to Argentina were also funded by Robinson College and the Centre of Latin American Studies. While working on this book I benefited enormously from the friendship and helpful advice of many colleagues in Argentina, including Cristina Reigadas, Clara Kriger, Sandra Gasparini, Carlos Gamerro, Federico Lorenz, and Pablo Piedras. Cecilia Gil Marino aided me in tracking down some of the more elusive materials that formed the basis of my research for the first chapter in particular.

Closer to home, a symposium organized by Ian James in 2013 in Cambridge, "Science and Technology in Contemporary French Thought," opened up some fruitful paths of research. Gerald Moore was very generous in sharing his expertise on Stiegler with me, and I am also grateful to Ed King for his feedback on a draft of the second chapter and for the inspiration of his own work on graphic fiction.

Early versions of some of the material contained in this book have been published, or are forthcoming, in journals and edited volumes. The section on Holmberg formed the basis of an article in Spanish to be published with the title "Reflexividad en la obra de Eduardo Holmberg: El rol de la ciencia ficción y la fantasía en la modernización y el control de las masas" in a special issue of the Revista iberoamericana, "La ciencia ficción en América Latina: Aproximaciones teóricas al imaginario de la experimentación cultura." The section on El Eternauta is drawn from an article entitled "Intellectuals, Revolution and Popular Culture: A New Reading of El Eternauta," published 
in Journal of Latin American Cultural Studies 19, no. I (March 2010). Part of chapter 6 appeared in Arizona Journal of Hispanic Cultural Studies I6 (2012) and another part in a compilation of essays edited by Jennifer Feeley and Sarah Wells with the title Simultaneous Worlds: Global Science Fiction Cinema (University of Minnesota Press, 2015). I am grateful to the publishers for their permission to reproduce this material. 


\section{Contents}

Introduction I

I. Fantasy and Science between Intellectuals and the Masses I5

Science, Fantasy, and the Masses in Holmberg's

Narrative Fiction 16

El Eternauta: The Intellectual in War and Revolution $3 \mathrm{I}$

Conclusion: Materialism, between Darwin and Marx 47

2. Mediation and Materiality in Graphic Fiction $5 \mathrm{I}$

Myth and Materiality in the Neoliberal City:

Ricardo Barreiro's Science Fiction Comics 54

Comics, the Archive, and Cognitive Practices 68

Conclusion: (Re)materialization in Graphic Fiction 79

3. Time, Technics, and the Transmission of Culture 8I

Cultural Transmission, Apocalypse, and the End of History in Plop 84

Evolution in Reverse: Post-Darwinism and Mnemotechnics in El año del desierto 88

Cruz diablo: Technics, Psychopower, and the

Cybernetic Gaucho 96

Conclusion: The End of (Universal) History IO4 
4. Projection, Prosthesis, Plasticity: Literature in the Age of the Image 106

Life beyond Death in the Cold Chemistry of

Quiroga's Celluloid Screens Io8

The Magic of Machines: Anthropomorphic and

Cosmomorphic Desire in La invención de Morel II4

El juego de los mundos: From Prosthesis to Plasticity II

Conclusion: Plasticity and the "Dusk of Writing" I28

5. Beyond the Linguistic Turn: Mathematics and New Materialism in Contemporary Literature and Theater I3I

The Mathematics of the Material Universe:

The Science Fiction Theater of Javier Daulte and

Rafael Spregelburd I33

New Subjectivities and New Materialisms in

Marcelo Cohen's Metafictions I42

Conclusion: The "Eternal Dance of Atoms" I52

6. Modernity and Cinematic Time in

Science Fiction Film 154

Polytemporality in Estrellas and Cóndor Crux:

A Critique of the Homogeneous Time of

Historicism and Modernity I55

Retrofuturism and Reflexivity: The Construction of

Cinematic Time in La antena and La sonámbula I7I

Conclusion: (Post)Modernity and Cinematic Time 187

Conclusion 192

Notes $\quad$ I97

Bibliography 215

Index 229 


\section{Introduction}

"Argentine science fiction does not exist." This claim, the opening statement of Elvio E. Gandolfo's chapter on the subject in El libro de los géneros, ${ }^{1}$ has been repeatedly echoed by critics. At best, science fiction in Argentina has been relegated to a minor and poorly defined branch of the nation's more celebrated tradition of fantastic literature. In this vein, Elsa Drucaroff asserts that Argentine texts may have adopted elements of science fiction, but none of them can really be said to belong to the genre. ${ }^{2}$ Pablo Capanna, perhaps the nation's most established science fiction critic, dedicates only a brief epilogue to Argentine examples in the updated (2007) version of his canonical El sentido de la ciencia ficción (1966), and observes the scant presence of technology in the texts he surveys. He suggests that they should really be read as a nontraditional form of fantastic literature that borders on science fiction. ${ }^{3}$

The view that science fiction is insufficiently developed as a genre in Argentina is perhaps an understandable response to the overwhelming dominance of generic models from the United States and Europe. The association of science fiction with foreign, imported literature is reinforced in the categories used by publishers and booksellers in Argentina: the shelves dedicated to science fiction in bookshops are exclusively stocked with literature in translation, while even widely acknowledged Argentine practitioners of the genre, such as Angélica Gorodischer and Carlos Gandini, are relegated to the "literatura nacional" section. If science fiction has still to be recognized as a genre within national literature, this is partly because many of its most distinguished authors-Leopoldo Lugones and Adolfo Bioy Casares, for example-did not exclusively dedicate themselves to the genre, but also because they and other writers have not, unlike in the United States, become 
the target of marketing campaigns that have relied on the strategic labeling (and retro-labeling) of texts as SF.

Critics have followed suit in downplaying the presence of science fiction in Argentina and reinforcing an overly restrictive genre classification. This has led to a dearth of critical work on the subject that might create new and alternative genealogies within Argentine literature; among other omissions, it has also sidelined a very important flourishing of the genre in graphic fiction, for example, of which Oesterheld's El Eternauta may be the most famous but certainly not the only example. I find sufficient the simple definition of science fiction offered by Capanna (borrowing from Judith Merril) as "la literatura de la imaginación disciplinada" (literature of the disciplined imagination), which describes texts that apply a scientific logic to explore even the most fanciful of hypotheses, and scrupulously avoid supernatural explanation. ${ }^{4}$ This broad definition allows us to unshackle science fiction from any particular worldview or developmental context. Drucaroff's unease stems from her observation that Argentine writers appropriate aspects of science fiction to serve a very different project: to address questions of backwardness, barbarism, dependence, and the unfulfilled promises of development. ${ }^{5}$ By suggesting that these questions are somehow out of place in science fiction, however, she seems to ignore the fully fledged critique of modernity and technologization that also exists within mainstream First World science fiction (in which atavism is by no means a rare threat, for example), and to imply that the genre is necessarily tied to a certain ideology and state of development.

It is certainly the case that Argentine science fiction is most often of the "soft" rather than the "hard" variety, bringing social or political issues to the fore rather than adopting a rigorously scientific approach to imagined technologies or advanced theoretical work in physics. There are no equivalents to the detailed expositions of complex mathematics or quantum ontologies in Greg Egan's Diaspora (1997) or Schild's Ladder (2002), or the advanced astronomical knowledge that underpins Alastair Reynolds's Revelation Space Universe. Argentine science fiction is far more likely to engage in speculation concerning posthuman identities or the social or psychological impact of new technologies of simulation and artificial life, along the lines of Philip K. Dick's Ubik (1969); to engage in a critique of colonialism, such as the one that underpins H. G. Wells's The War of the Worlds (I898); to explore alternative social and economic systems, as in Ursula K. Le Guin's The Dispossessed (1974); or to create dystopian visions of the repression of culture, as Ray Bradbury does in Fahrenheit 45I (1953). 
The relative absence of "hard" science entirely befits, of course, a branch of science fiction that often maintains a critical distance from Western modernity and its technological imaginaries. However, although Argentine science fiction boasts fewer examples of futuristic machines than many European and North American variants of the genre, and is less indebted to the intricacies of quantum physics, it is not the case that it cannot be distinguished from the fantastic tradition. I would suggest that a cleavage between the two begins to open up as early as I865, with the publication of Juana Manuela Gorriti's "Quien escucha su mal oye." The story relates a case of hypnosis, and the narrator freely admits that the scenario presented appears to be an entirely fantastical one, in which anyone witnessing the powers of the female hypnotist "habríasele creído una maga celebrando los misterios de un culto desconocido" (would have believed her to be a magician performing the mysteries of an unknown rite) ${ }^{6}$ However, he insists that she is a scientist, drawing attention to the anatomical drawings, cranium models, and books on the chest of drawers, all of which are authored by chemists, naturalists, physiologists, and physicians of the eighteenth and nineteenth centuries: Christoph Wilhelm Friedrich Hufeland (1762-1836), FrançoisVincent Raspail (1794-1878), and Gabriel Andral (I797-I876). In doing so, he postulates a natural, rather than a supernatural, basis for the seemingly fantastic events of the story. Ten years later, this emphasis on the empirical exploration of unknown realms of both the human psyche and the planetary system would be developed in the narratives of Eduardo Ladislao Holmberg (see chapter I) to form the genesis of the SF genre in Argentina.

A central hypothesis of this book is that the science fiction genre in Argentina may be differentiated from the fantastic tradition with respect to its commitment to exploring materialist conceptions of the universe, a characteristic that is notable from the genre's beginnings and has become even more marked in recent decades. Further, I argue that Argentine science fiction typically deploys reflexive and metafictional techniques at the service of a materialist understanding of the text. The use of reflexivity to pursue a materialist agenda will be surprising to anyone versed in standard postmodern theories of metafiction and intertextuality. Patricia Waugh offers a definition of metafiction as "a term given to fictional writing which self-consciously and systematically draws attention to its status as an artefact in order to pose questions about the relationship between fiction and reality"; she argues that such writings also posit the fictionality of the world beyond the text, reflecting "a greater awareness within contemporary culture of the function of language in constructing and maintaining our sense of everyday 'reality.'”' By 
drawing attention to their own methods of composition, then, and creating multiple mise en abyme effects, reflexive texts persuade us that what we take as reality is always mediated through discourse, having no existence beyond our linguistic constructions of it. Metafiction is thus often taken to serve a philosophy underlying the "linguistic turn" in critical theory, which emphasizes the social and linguistic construction of reality, and anchors postmodern thought to an idealist tradition in philosophy.

I wish to argue for an alternative function of metafiction, at work in many of the texts explored in this book, which does not emphasize the fictionality of the world so much as the materiality of the text. Rather than positing a reality made up of texts, these works choose to present the text as sharing in the same substance as the universe beyond it, both caught up in, and shaped by, the same forces; to draw attention to the embodied nature of the experiences of writing, reading, illustrating, performing, and spectating; and to explore how literary and other kinds of texts may enhance, and bring us to a greater understanding of, our sensory contact with the world. If philosophical idealism leads us to believe that what we imagine manifests itself in the material realm, then the world is effectively an illusion constructed by human language and social discourses. A materialist outlook, on the other hand, would find our imagination to be an effect of complex interactions of matter, and seek to explain human culture with reference to material conditions or the evolution of technology.

A framework for a materialist genealogy of Argentine science fiction, offered here as intentionally provisional and provocative, would exclude some of the texts that are already snugly nested within the canon, or at least relegate them to a different line of descent. The work of Angélica Gorodischer, often declared to be the most undisputed practitioner of the genre in Argentina, deploys many of the narrative topoi that distinguish science fiction, such as space travel and first-contact scenarios with alien races. However, her abiding interest in the arbitrary nature of the linguistic sign, and the extent to which language structures perception and interpretation of the world around us, situates her fiction very much within a (post)structuralist paradigm. The tangled narrative hierarchies of "Onomatopeya del ojo silencioso," in which the diegetic narrator's account—ostensibly the story we read-is revealed to be identical to the text recited by the alien race within the story, place it in a much clearer relationship with the fantastic tradition epitomized by Cortázar's "Continuidad de los parques" than with the other incursions into science fiction explored here. In "Los embriones del violeta," words bring material objects into being, just as the false Encyclopaedia of 
Borges's "Tlön, Uqbar, Orbis Tertius" creates a new, fictitious world that begins to invade our own. Gorodischer's stories, parables of linguistic relativism and social constructivism, act as a useful foil against which to measure the materialist thrust that I have found to be characteristic of the greater part of Argentine science fiction.

Unlike several of the European and North American examples mentioned above, much science fiction in Argentina remains resolutely located on our own planet, within a reality that is estranged to differing degrees, rather than in another part of the known, or invented, universe. This has strengthened the already dominant tendency toward historicizing approaches in science fiction criticism. In his Postales del porvenir: La literatura de anticipación en la Argentina neoliberal (1985-1999), for example, Fernando Reati reads his selected corpus as "una ilustración de ciertas obsesiones y temores presentes en el imaginario argentino de esos años" (an illustration of certain obsessions and fears present in the Argentine imaginary in those years). ${ }^{8} \mathrm{He}$ adopts a stance common among science fiction critics when he reminds us that "en toda literatura de anticipación imaginar el futuro es un ejercicio de indagación en los aspectos más dolorosos del presente" (in all speculative fiction, imagining the future is an exercise in probing the most painful aspects of the present). ${ }^{9}$ It is certainly the case that Argentine science fiction, while engaging with themes common to the genre across the industrialized world - from the abuse of technology by authoritarian regimes to new modes of posthuman subjectivity and apocalyptic visions of environmental catastrophe-is also thoroughly grounded in the specific social and political life of the nation. Among other issues, the texts examined here explore the impact of an uneven modernization, mass migration, dictatorships, crises in national identity stretching back to the nineteenth century, the rise and fall of the Left, the question of the nation's indigenous heritage, the impact of neoliberalism, and the economic crisis of $200 \mathrm{I}$.

While clearly rooted in the contexts of its production, however, Argentine science fiction is also highly reflexive, meditating openly on questions of form and genre, and debating within its pages the role of science fiction and fantasy - and literature and art more generally—in the society of its day. As Damien Broderick points out, SF as a genre is characterized by an "enormously ramified intertextuality," as "the coding of each individual sf text depends importantly on access to an unusually concentrated 'encyclopedia'-a mega-text of imaginary worlds, tropes, tools, lexicons, even grammatical innovations borrowed from other textualities." 10 This tendency is magnified in Argentine science fiction, which consciously engages with the 
genre from a peripheral position. Capanna observes that Argentine writers have been influenced not so much by science directly as by reading science fiction, which often arrived in the form of translations published in popular magazines; ${ }^{11}$ this has only heightened a critical reflexivity already typical of the genre. Composing science fiction from the postcolonial periphery often brings an ironic and parodic perspective to bear on familiar stories of alien invasion and conquest, for example, as it does in H. G. Oesterheld's allegory of neocolonialism in his comic series La guerra de los Antartes (1970, 1974), in which Russia and the United States strike a deal with the aliens, offering them total domination over South America in exchange for a cut of the sizable profits to be made from developing the continent's natural resources.

My aim in this study is therefore to balance contextual readings of Argentine science fiction with a sustained focus on the broader theoretical questions these texts raise, through their marked reflexivity, concerning the nature and role of literary, cinematic, and theatrical texts within human culture and society. My corpus is diverse, spanning texts produced in Argentina from 1875 to the present day, and across a range of media and forms of performance: literature, cinema, comics, and theater. I do not pretend to offer a comprehensive overview of Argentine science fiction, however: my particular focus on reflexive practices within the genre has led to the exclusion of certain works and writers that could not be omitted in a more exhaustive survey, such as key texts by Leopoldo Lugones (Las fuerzas extrañas) and Horacio Quiroga ("El hombre artificial," "El mono que asesinó"), as well as the work of Carlos Gandini. I do otherwise, however, include those Argentine SF texts that would be central to a canon if one were recognized: Eduardo Holmberg's Viaje del señor Nic-Nac al planeta Marte, H. G. Oesterheld's El Eternauta, and Adolfo Bioy Casares's La invención de Morel. I place alongside these a number of texts by writers who might be considered to bridge fantasy and SF (Horacio Quiroga, Rafael Pinedo, Eduardo Blaustein, César Aira, Marcelo Cohen), focusing in each case on those texts that engage most clearly with the genre of science fiction. Argentine cinema has produced few SF films, for reasons I give in chapter 6; the four I have selected for discussion all reflect critically on the codes of science fiction and its manipulation of temporality and historicity. They represent a range of approaches, including a semidocumentary film (Estrellas), an animated production (Cóndor Crux, leyenda del futuro), and a highly unusual, mixedaesthetic film that pays homage to early cinema and to comics (La antena), as well as the most well-known and critically acclaimed SF film of recent decades (La sonámbula). Theatrical experiments with science fiction are also 
unusual, but I focus on two key exceptions to the rule, by Javier Daulte and Rafael Spregelburd, in chapter 5. One of my objectives in this book is to highlight Argentina's significant tradition of science fiction comics and graphic fiction, which stretches far beyond the single iconic text (El Eternauta) known to most readers; chapter 2 thus focuses on the work of one of the nation's most significant scriptwriters, Ricardo Barreiro, who was responsible for a flourishing of SF comics series in the I980s and I990s.

One of the abiding reflexive concerns in Argentine science fiction is the relationship between elite and popular culture, or more broadly between intellectuals and the masses, a theme that provides the focus for chapter I. The first part opens with a discussion of the novel widely recognized to represent Argentina's first work of (proto-)science fiction, Eduardo Holmberg's Viaje maravilloso del señor Nic-Nac al planeta Marte (1875), before contrasting it with his later utopian novel Olimpio Pitango de Monalia (I915). Holmberg, a natural scientist who played a key role in disseminating Darwin's ideas in Argentina, chose to explore the potential of fiction, and often fantasy, to stimulate scientific curiosity and to circulate new theories and knowledge beyond the academy. However, his reflexive narratives ultimately betray an equivocal approach to the role of fantasy and literary utopianism in the nation's modernization project, as a potential force for the manipulation of the masses as well as their education. Both science and fantasy, it would seem, lend themselves more readily to shoring up the status of the elite and extending its grip on the masses than to any genuinely democratizing or modernizing agenda.

The second part of the chapter develops the reflexive theme of the relationship between intellectuals and the masses, but winds forward to two more recent periods of Argentine history: the civil unrest of the mid-I950s, and the repression of left-wing militancy in the 1970s, as registered in the two major series of El Eternauta (Oesterheld and Solano López), Argentina's most revered and popular science fiction comic. My reading diverges significantly from previous scholarship on the two series, paying close attention to their self-conscious interventions in debates of their time concerning the role of the intellectual in relation to politics and the pueblo. I argue that key differences in the presentation of the intellectual between the first and second series reflect the seismic change that took place between the Sartrean "intelectual comprometido" (committed intellectual) of the I950s and early I960s, and the anti-intellectualism of left-wing militancy of the I970s in Argentina.

The conclusion to chapter I takes up the theme of materialism in relation 
to the highly reflexive fictions composed by both Holmberg and Oesterheld. In different guises, the conflict between materialism and alternative conceptions of the universe-spiritism in the late nineteenth and early twentieth centuries; later, forms of philosophical idealism and social constructivismshapes many of the science fiction texts discussed in this book. Holmberg's inaugural contributions to the genre are marked by the shifting contrapositions and accommodations between materialist and spiritist conceptions of life that were characteristic of his era, while Oesterheld's texts are anchored to more solidly Darwinist and Marxist forms of materialist thought.

The relationship between metafiction and materiality becomes the focus in chapter 2 of a discussion of several comic series scripted in the I970s and 1980s by Ricardo Barreiro. Examining the use of intertextuality, parody, and mise en abyme in Slot-Barr (1976), Ciudad (1982), Ministerio (1986), and Cain (1988), I argue that these devices do not ultimately lead us to question the text's ability to represent the world beyond it or to posit reality as a mere illusion constructed through language. Against this prevailing (postmodern) understanding of metafiction, I suggest that the deployment of reflexive devices in graphic fiction does not point to the immateriality of the world so much as the materiality of the text. My discussion of Barreiro's work engages critically with key concepts emerging in the relatively new field of comics theory. In particular, I explore the notion of the comic as archive developed in the work of Jared Gardner and Jörn Enns, who draw in very suggestive ways on Walter Benjamin's writings on the modern city. While noting the usefulness of this metaphor to account for the particular mixture of mythology and materiality in comics and their capacity to evoke the forms and textures of urban space, I conclude that it also conceals the more active role of comics in transforming, translating, and remediating the material they appropriate, and does not sufficiently draw out the processes of (re)materialization that are intrinsic to the medium.

Among other reflexive concerns, science fiction in Argentina has often imagined a crisis in cultural transmission, prophesying the demise of literature or the sudden wiping-out of decades or centuries of accumulated knowledge. This dystopian vision unites the novels explored in chapter 3: Cruz diablo (Eduardo Blaustein, 1997), Plop (Rafael Pinedo, 2004), and El año del desierto (Pedro Mairal, 2005). I argue that the particular understanding of literature (and other forms of cultural expression) developed in these texts may be illuminated by exploring revisions to Darwinian theories of evolution that have recently been pursued in anthropological thought and cultural theory. The novels may be read as articulating a shift from a Dar- 
winist model of inheritance based on the transmission of genes to a newer understanding - promoted by André Léroi-Gourhan, Bernard Stiegler, and others, and often termed "gene-culture co-evolution" —of the significant role of technology and tools in human evolution. In addition to individual memory and the genetic memory of species, Stiegler posits a "third memory" that enables the transmission of individual experience from one generation to another, via inscriptions in tools and other technical artifacts, prominent among which is the written text. What Stiegler calls "technics" he finds to be responsible for the accelerated evolution of the human species-which natural selection cannot alone explain - and to be so central to our experience that "humanity cannot even be understood without technics." 12

This understanding of human evolution may loosely be termed "postDarwinist," as it exceeds Darwin's theory that individual experience, in the form of acquired characteristics, cannot be inherited by future generations of the same species. As will be evident from my discussion of Plop, El año del desierto, and Cruz diablo, however, it remains thoroughly materialist in its emphasis on the material supports essential to the transmission of culture. Within a critique of neoliberal capitalism and a fictional meditation on Argentina's fall from prosperity (explicit in the latter two texts), these novels demonstrate how quickly cultural knowledge, the possibility of progress, and even a sense of linear temporality itself dissipate with the demise of the tools and technologies that enable the transmission of culture from one generation to another.

This understanding of literature as a form of prosthesis is further developed in chapter 4 with reference to a selection of science fiction narratives that take as their central theme new or invented technologies of visual recording and projection, ranging from enhanced versions of photography and cinema to forms of virtual reality. In my discussion of a selection of Horacio Quiroga's short stories from the I920s, together with Bioy Casares's La invención de Morel (1940) and César Aira’s El juego de los mundos (2000), I focus on these texts' explorations of the different kinds of perception and subjectivity that are produced as we interact with new technologies, and what role literature might continue to play in an age of the image. A recourse to science fiction thematics allows writers to address in very direct terms the idea of visual technologies as forms of prosthesis, transforming, supplementing, or redistributing subjectivity. The invention of futuristic technologies in these texts becomes a way of reflecting more generally on the prosthetic nature of older forms of inscription. As N. Katherine Hayles observes, "Writing is a way to extend the author's body into the exterior world; in this sense, 
it functions as a technological aid so intimately bound up with his thinking and neural circuits that it acts like a prosthesis." ${ }^{13}$ Like any other prosthetic technology, literature extends our perceptions beyond our immediate physical environment. Marshall McLuhan was unequivocal about the matter: "All media are extensions of some human faculty—psychic or physical. ... The book is an extension of the eye." ${ }^{14}$ In El juego de los mundos, we witness a move from questions of projection and prosthesis to a new paradigm of plasticity, and I explore the consequences of this shift via a discussion of Catherine Malabou's Plasticity at the Dusk of Writing (2010).

Recent theatrical works by Rafael Spregelburd are at the forefront of a new interest among Argentine dramatists and performers in exploiting the capacity of theater to construct forms of material, embodied experience that cannot be reduced to the linguistic. Theater, as Jorge Dubatti suggests,

a diferencia de la literatura escrita, del cine o de la plástica, ofrece por su naturaleza convivial una experiencia que es mucho más que lenguaje. Una experiencia que hunde sus raíces en la misteriosa autopercepción de las presencias corporales, el tiempo y el espacio vivientes. ${ }^{15}$

in contrast to written literature, cinema, or the plastic arts, offers, by virtue of its form as a gathering, an experience that is much more than language, an experience that is rooted in the mysterious selfperception of embodied presences, a living time and space.

Chapter 5 contrasts the recourse to mathematics and post-Newtonian physics in Spregelburd's work with that of Javier Daulte. While Daulte's $4 D O_{p-}$ tico (2003) finds Einstein's theories of relativity to destroy any possibility of an objective, material reality beyond our illusions, Spregelburd's La paranoia (2008) draws on the self-similar patterns of fractal geometry and the complex dynamic systems described by chaos theory to gesture toward a form of material patterning and meaning in the universe that exceeds the order imposed by human language. He constructs a postanthropocentric vision in which human agency is recognized as merely one force among the many, both organic and inorganic, that shape the material world.

Focusing on Cohen's Variedades (1998) and Donde yo no estaba (2006), the second part of the chapter discovers in these novels a similarly postanthropocentric understanding of subjectivity and the materiality of the text, and draws them out with reference to theories that have been recently brought together under the term "new materialism." Exemplified by the work of 
Manuel De Landa, Donna Haraway, and Rosi Braidotti, among others, these theories respond to the dominance of the "linguistic turn" and social constructivism in (post)structuralist and deconstructionist approaches. In its place, they emphasize the processes that embed human experience within the material world and question the central language/reality dualism that has remained unchallenged in postmodern thought. In an analogous manner, Cohen situates human experience and agency within much broader interactions between material forces, including the nonhuman and even the nonorganic. For him, the literary text does not occupy some transcendent position with regard to the material world but is fully part of its continual exchanges and transformations.

Finally, chapter 6 returns to earlier discussions of historicism, temporality, and prosthetic forms of experience (in chapters 3 and 4 ) to develop these ideas further in relation to the representation of modernity in four science fiction films. In different ways, La sonámbula (1998), Cóndor Crux, la leyenda del futuro (2000), Estrellas (2007), and La antena (2007) reflect on the role of cinema, and the cinematic apparatus, in the construction of temporality; this reflexive theme is combined in all cases with a critique of modernity from a postcolonial perspective, with a particular focus on its universalizing pretensions and blind faith in progress. Specifically, these films reject a historicist worldview, understood as a universalizing approach that charts world history as a series of developmental stages, in which one naturally follows another. By contrast, their reflexive exploration of cinematic temporality allows them to unpick the chronology of modernity. My discussion engages with (neo-)Marxist and historical-materialist readings of science fiction but ultimately finds Benjamin's approach more compelling, in its understanding that a critique of modernity and capitalism can only really be made on the basis of a more fundamental critique of the concept of historical progression. These films' reflexive exploration of cinematic time allows us to appreciate the extent to which cinema is able to register and reshape the multiple temporalities that make up the present, to confound the linear narrative of modernity, and to refound utopian visions of a different future.

The fantastical and futuristic elements of science fiction might lead us to read the genre as a hyperbolic instance of the capacity of fiction to construct a world through thought and language, much as the Captain of Eduardo Goligorsky's "La cola de la serpiente" (1967) succeeds in re-creating an entire planet merely by remembering it and expressing a desire in his own mind. As Broderick suggests, in his discussion of SF reflexivity, "To read fiction of any kind is to help create a world, built out of words and memories and 
the fruitfulness of imagination." ${ }^{16}$ This vision of the idealist function of literature, however, is ultimately supplanted in a good number of Argentine science fiction texts by a commitment to a material understanding of the text. Braidotti contends "that science fiction enacts a displacement of our world-view away from the human epicentre and that it manages to establish a continuum with the animal, mineral, vegetable, extra-terrestrial and technological worlds," thereby pointing to a "post-humanist, bio-centred egalitarianism." 17 All the texts discussed here establish such a continuum, but they also undertake a reflexive examination of the role and status of literature, cinema, theater, or graphic fiction within those material and technological worlds. In doing so, they find new uses for metafiction and reflexivity that do not further philosophies of linguistic constructionism but instead challenge the dominance of the linguistic paradigm, turning toward a more materialist view of culture.

That materialist view presents itself in different guises, of course, depending on the historical moment of each text's production and its particular ideological orientation. On a theoretical level, one of the aims of this book is to trace relationships between new materialism and older forms of materialist thought, and to explore ways in which these open up or close off different practices of literary criticism. There are many points of contact between new materialism, Darwinism, and Marxist materialism, for example, as well as significant points of divergence. Darwin's On the Origin of Species (I859) was greeted with immense enthusiasm by Marx and Engels, who found in it a materialist explanation of nature's history that mirrored, and strengthened, their materialist approach to human history. In many ways, however, Marx and Engels went beyond Darwinian evolution to anticipate theories of gene-culture coevolution that were to become widespread in the 1970s and 1980s. ${ }^{18}$ John Bellamy Foster demonstrates that human evolution, for Marx, "had to be traced through the development of tools, much more than fossils," as a reliance on tools as exterior extensions of the body was unique to human, rather than animal, evolution. ${ }^{19}$ We may detect further prefigurings of Stiegler's technics-and materialist, posthuman identities-in Marx's understanding that technology reveals to us "the active relation of man to nature" and thereby how social relations are produced as well as "the mental conceptions that flow from those relations." 20 While allowing for the distinctiveness of human evolution, Marx insisted on material explanations: "The statement that the physical and mental life of man, and nature, are interdependent means simply that nature is interdependent with itself, for man is a part of nature." ${ }^{21}$ As Bellamy Foster explains, Marx was later to use the concept of metabolism to account for the process of labor, "with its 
attendant notions of material exchanges and regulatory action" to explain the human relationship with nature as one that involved both naturally occurring conditions and the human capacity to affect that process. ${ }^{22}$ Marx observes a dialectical process here, in which humans change the environment around them, but such changes lead them in turn to "transform themselves, develop new powers and ideas, new modes of discourse, new needs and new language." ${ }^{23}$ Under capitalism, a "rift" in that metabolic relation with nature opens up, whereby humans are estranged and alienated from the natural conditions on which their existence is founded. ${ }^{24}$

The dynamic relationship of material, metabolic exchange between humans and nature (both organic and inorganic) observed by Marx resonates strongly with the complex interactions witnessed by new materialists. A key difference, however, emerges between new materialist thought and the Marxist critical tradition: for new materialists, commodities do not invariably represent "false consciousness." As Maurizia Boscagli suggests in Stuff Theory, the new materialist understanding of the commodity positions it as environment, "potentially capable of producing, rather than blocking, experience"; as such, it liberates energies that may be used "for emancipatory ends." ${ }^{25}$ Here, perhaps, we detect the greater influence of Benjamin's particular understanding of materiality and the commodity form, which, Boscagli suggests, "is interested in what to do with things and the pleasures they provide, and in what things can do, rather than in how the subject simply consumes and is consumed by the fantasies they circulate." 26 The importance of Benjamin's sense of the emancipatory potential of commodities and technologies is discussed further in the conclusion, and it is this awareness that informs the approach adopted by a number of science fiction films discussed in the final chapter, especially La antena and La sonámbula.

Following in this line, for new materialists, technological mediation and the proliferation of images and simulacra are not necessarily agents of alienation, as they are for many Marxist critics and theorists. For Paul Virilio and (particularly the early) Jean Baudrillard, technology ushers in an ever-greater independence and alienation from the natural world; the increasing integration of humans with technologies essentially challenges what it means to be human. ${ }^{27}$ In new materialist thought, human subjectivity has always coevolved with technology, and both technology and nature belong to a material realm in which we are thoroughly immersed, but which is also exterior and autonomous with respect to human agency. If many theorists and critics have emphasized the dematerializing effects of late capitalism, from the complex system of derivatives that underpins the contemporary financial system to the rise of electronic media, the more contemporary texts I discuss 
here (particularly those by Aira, Cohen, Blaustein, and Mairal) refuse to postulate a human subjectivity that has become in any way divorced from the material conditions of its existence, or to imagine new media technologies as different in essence from older ones.

New materialism thus emerges as a powerful framework for literary and cultural criticism that, while remaining staunchly committed to a materialist understanding of culture, human experience, and textuality, exposes the deficiencies of a continued Marxist reliance on dualisms, symptomatic readings (e.g., Fredric Jameson), and linear models of historical progress. It provides a way of moving beyond these, as well as the linguistic turn enshrined in postmodernism, to focus on the text in a way that does not reduce its materiality to language. In the conclusion, I focus on Mark Hansen's charge of "technesis," laid against a whole genealogy of thinkers who have privileged logocentric thought over "the robust materiality of technology," which exceeds representation. ${ }^{28}$ The theorists on whose work I principally draw in my analyses-Benjamin, Stiegler, Malabou, and Braidotti—do attempt, I argue, to think through the material dimensions of human existence that precede and transcend our capacity to reduce them to language. This endeavor is also evident in the metafictional techniques of the science fiction texts discussed here, which often present literary, cinematic, or other forms of text as technics that shape our experience of temporality and our relationship with the material environment, beyond language or symbolism.

I go on in the conclusion to advance a hypothesis concerning the prevalence of materialist thought in Argentine science fiction, identifying in these texts a sustained critique of capitalism that stretches back to the nineteenth century but acquires a particular urgency under neoliberalism and more recent years of financial crisis. I sketch out ways in which these texts' engagement with the philosophy of capitalism is also, in many ways, a critical response to the influence of models of society and evolution inspired by Darwinian thought. This allows us to understand Argentina's position on the periphery of the modernizing world as a privileged context, perhaps, for a reflexive exploration of the adoption of technics in human culture, as a form of resistance to the central tenet of adaptation within the ideology of capitalism. Inscribing themselves within a genealogy of materialist thought and drawing on the defamiliarizing techniques of the science fiction genre, these texts assume the task of rethinking human subjectivity in a material world of technology in which the human is increasingly displaced—or more accurately, returned to a place within the material world and not above itallowing new forms of experience to become possible. 


\section{1 / Fantasy and Science between Intellectuals and the Masses}

The texts discussed in this chapter include two of Argentina's most iconic science fiction texts: Eduardo Holmberg's Viaje maravilloso del señor Nic-Nac al planeta Marte (1875), often cited as one of Latin America's very first science fiction novels, and the two principal series of El Eternauta, the epochal comic scripted by Héctor Germán Oesterheld and illustrated by Francisco Solano López (1955-57, 1976-77). The danger-real or imagined-of societal collapse, political rupture, and a descent into chaos is acutely present in these texts' staging of a range of encounters between science and popular culture, and intellectuals and the masses. They are written at three different points in history that are united by the experience of social crisis and a serious threat to the continued viability of specific narratives of nationhood. The economic growth and modernization that had begun to gather force in Argentina during the 1870 s were accompanied by a rise in immigration that threatened to undermine a sense of national identity and unity; the specter of civil war overshadows the publication of the first series of El Eternauta in the 1950s; and the worst fears of social disintegration and violence are realized in the militancy and authoritarianism of the r970s.

Although they bridge a century, these texts have much in common in their experimentation with popular genres and media for the dissemination of scientific or political ideas, and their exploration of the relationship between intellectuals and the masses. They open up reflexive spaces in which Holmberg and Oesterheld question their own roles as writers and intellectuals: in Holmberg's case, this leads to a suspicion that fiction and fantasy may 
be tools of oppression and obfuscation as well as liberation and education, and in Oesterheld's, to a profound uneasiness concerning the role of the intellectual in revolutionary political action. Their texts critically examine the capacity of science fiction to disseminate new scientific ideas and to bring together elites and popular classes in noninstitutional spaces. In the work of both writers we may begin to trace the importance of materialist thought in Argentine science fiction, particularly in their shared recourse to a Darwinian framework to explain class struggle, and in Oesterheld's Marxist understanding of the relationship between human labor, nature, and technology.

\section{Science, Fantasy, and the Masses in Holmberg's Narrative Fiction}

Eduardo Ladislao Holmberg (I852-1937) has been universally celebrated as a paragon of progressive thought in late nineteenth-century Argentina. He was a pioneering natural historian, the dynamic director of the new Zoological Gardens in Buenos Aires, the founder of the nation's first journal exclusively dedicated to biology, the scientist chiefly responsible for the dissemination of Darwin's ideas in Argentina, and, following Domingo Faustino Sarmiento, a passionate campaigner for universal education. Holmberg was also a man of letters, publishing a number of novels and even poetry as well as groundbreaking scientific studies and expedition reports. Recent scholarship has paid greater attention to the extraordinary role Holmberg carves out for literature and utopian fantasy at a time of great taxonomic fervor in the natural sciences. It is in Holmberg's fiction that some of the modernizing zeal of his work as a scientist and educator is subjected to irony and doubt, providing insight into the complexity of discourses of science and progress in Argentina during this period. While he was a prominent adherent of the positivism so enthusiastically embraced by his generation, in his novels and short stories Holmberg repeatedly suggests that the hidden truths of the universe may not always yield to empirical testing.

Holmberg's eccentric fictions are a wild mixture of gothic mystery, occult sciences, and unorthodox uses of natural history, anthropology, and phrenology. They were so disconcerting to contemporary readers that they did not find a place within the literary canon for many years. ${ }^{1}$ Viaje maravilloso del señor Nic-Nac al planeta Marte was published as a folletín in El Nacional in 1875 and again as a book in that same year, but a new edition was not released until 2006; Olimpio Pitango de Monalia, Holmberg's most thoroughly utopian work, was written in I9I5 but published for the first 
time almost eighty years later. It is only in recent years that Holmberg has attracted significant attention as a writer of fiction, particularly as the result of a growing interest among critics in tracing literary genres back to their nineteenth-century roots. This has resulted in a number of excellent studies of his work, including those published in Adriana Rodríguez Pérsico's Relatos de época: Una cartografía de América Latina, I880-1920 (2010), Paula Bruno's Pioneros culturales de la Argentina: Biografías de una época, I860-I9Io (20II), and Sandra Gasparini's Espectros de la ciencia: Fantasías cientificas de la Argentina del siglo XIX (2012). These texts cast light on feverish, turbulent exchanges that bring together science, speculation, the literary press, and the modernizing policies of the state in a context of profound social and cultural change, driven by mass immigration.

My aim is to extend the work of these scholars by delving more deeply into the reflexive exploration of the fantastic genre in Holmberg's texts. The intersections between science, fantasy, and utopia in these texts reveal a good deal about the fluid relationship between science and esoteric forms of knowledge at the end of the nineteenth century. However, points of tension also arise between science and fantasy that bear witness to Holmberg's equivocal presentation of the role of fantasy and utopianism in the modernizing project of the Generation of I880. Holmberg questions his own use of fantasy in stimulating the imagination of the masses, and more broadly the role of fiction and literary uses of language in Argentina's educating and modernizing project. Viaje maravilloso reflects critically on its own use of popular genres and the popular press to disseminate scientific ideas, while Olimpio Pitango de Monalia reveals with even greater clarity Holmberg's ambivalence toward the use of fiction and mystery as a potential force for the manipulation of the masses as well as their education.

If, for some critics, Viaje maravilloso represents the first work of science fiction in Argentina, others have more cautiously described it as "protoscience fiction." Nic-Nac's journey to Mars is not undertaken with the aid of advanced technology, such as a spaceship; it takes place under the influence of a medium, Seele, and following the protagonists' transformation into "spirit-images," a kind of spiritual matter that is not bounded by time or space but nevertheless preserves individuals' identities and their sensory perceptions. Pressing questions of science and technology are articulated in the novel alongside those of a more esoteric or spiritual nature, with no sense of disjuncture: “¿Qué es la vida? no sé; ¿qué es la muerte? no sé; ¿qué es el éter? ¿Qué es la electricidad? no sé, no sê" (What is life? I don't know; what is death? I don't know; what is ether? What is electricity? I don't know, 
I don't know). ${ }^{2}$ The spiritist Seele is described as extremely well versed in all the physical and moral sciences, and his power as a medium rests on the fact that "le era igualmente familiar la interpretación de un fenómeno cósmico, como la explicación de un fenómeno psíquico" (the interpretation of a cosmic phenomenon came as easily to him as the explanation of a psychic phenomenon). ${ }^{3}$ The novel's most important point of engagement with scientific speculation of the time lies in its advance of the theory of the plurality of inhabited worlds, explored in the works (literary and nonliterary) of the French author and astronomer Camille Flammarion, which were circulating widely in Spanish translation at the time that Holmberg wrote Viaje maravilloso. ${ }^{4}$ However, as Gasparini notes, Viaje maravilloso differs from early European science fiction, such as that of Jules Verne, as it does not contain a "novum" and seems concerned less with the future possibilities of scientific and technological development than with passing sociological comment on the conditions of its own production. ${ }^{5}$

The delirious visions of Viaje maravilloso seem at first sight entirely discordant with Holmberg's meticulous work as a collector of botanical samples. As a scientist, Holmberg might have been expected to write one of the many naturalist novels of the period, often authored by literary-minded medics. ${ }^{6}$ In fact, far from displaying a clear pedagogical intent, the novel's seriousness is continually undermined by the mischievous humor that plays across its pages. The relative absence of "hard" science in the novel has been explained in various ways. It is often observed, for example, that science had yet to cleave definitively from spiritism at this point. Holmberg's choice of a nontechnological vehicle for his interplanetary journey pays homage to the great influence of spiritist beliefs in late nineteenth-century Buenos Aires, where Allan Kardec's writings enjoyed a wide circulation. It was undoubtedly influenced, too, by Flammarion's choice of cosmic travel for the protagonist of his Lumen (I872), as a disembodied spirit. ${ }^{7}$ It has also been suggested that, while Verne's journeys were made in vehicles readily at hand in the industrial cities of Europe, Holmberg's choice of a "nontechnological" vehicle-transmigration-reflected the relative absence of technology, not only in everyday life but also in public discourses in Argentina at the time. As Carlos Pérez Rasetti argues, the discourses of the Generation of I880 were not constructed by engineers but by lawyers and medics, and the principal preoccupation of their political and economic programs was not to develop industrial technology but to form a unified and ordered workforce of immigrants who would propel the nation's progress by exploiting its abundant natural resources. ${ }^{8}$

Although Holmberg's choice of fantasy was unusual for a scientist of his 
time, in many ways his approach was not so far removed from the realist, naturalist, or costumbrista modes widely adopted by writers of his generation. As Pablo Crash Solomonoff remarks, "Mientras Martín Fierro cruzaba los límites de la frontera de indios, Nic-Nac cruzaba los de la atmósfera" (While Martín Fierro was crossing the frontiers of Indian territory, Nic-Nac was crossing those of the atmosphere): ${ }^{9}$ both José Hernández’s classic poem and Holmberg's fantasy novel are marked with the same spirit of exploration in a pursuit of national integration and modernization (and after all, to the nineteenth-century mind-set, Indians might as well have been aliens). Holmberg applies a costumbrista attention to the local flora and fauna of Mars and scrutinizes with an anthropological eye the everyday life of its inhabitants. His detailed descriptions of Martian geography, right down to its distance in leagues from the sun at various points in its elliptical path, make for incongruously precise interventions in this fantasy journey of the spirit. A Romantic sensitivity to the power of the imagination and the life of the spirit is partnered with an exactitude in geological description that would have befitted one of Holmberg's scientific expedition reports. The classifying zeal of the nineteenth-century natural historian is evident in his account of Mars, on which "Cada ave tiene su nido, cada flor su perfume, cada insecto su matiz, cada pueblo sus costumbres, cada secta sus preocupaciones" (every bird has its nest, every flower its scent, every insect its hue, every people its customs, every sect its fears). ${ }^{10}$

How should we then read Holmberg's resort to fantasy? Does it serve his scientific vision, complement it, or compensate for it in some way? For Antonio Pagés Larraya, fantasy and science remain in irreducible conflict in Holmberg's work. He warns us not to give in to the temptation to find correlations between the naturalist and the writer of fantasy stories: Holmberg simply laid aside the methodical approach, patience, and order required for laboratory research when he invented his fictions, and "El hombre de ciencia y el escritor se regían por imperativos diferentes" (The man of science and the writer were governed by different imperatives). ${ }^{11}$ These fantasy worlds are, Pagés Larraya claims, just a kind of psychological safety valve for the pressures of complex intellectual work. Bonnie Frederick places fiction in a similar compensatory role in relation to science when she argues that Holmberg, together with Carlos Bunge and Eduardo Wilde, "construct a scientific discourse of power and authority. But they turn to literary discourse for the language of failure and anguish: failure to live their goal of objective science, failure to know the world well enough to use knowledge only for good, and anguish at the human suffering that their science cannot cure." ${ }^{12}$

Other critics have found fiction to play a more active role in relation to 
the divulgation of science in Holmberg's hybrid texts: not as compensation for science or light relief from its demands, but as a vital means of disseminating new theories and concepts. At a moment at which many disciplines were still in formation, Holmberg's fiction becomes a crucial space for the exploration of esoteric, dissident, eccentric, or improbable ideas that were not (yet) accepted in mainstream science. Gasparini writes: "Estas ficciones experimentan, efectivamente, con esas hipótesis descartadas, consideradas erróneas o imposibles por el ámbito académico" (These fictions effectively experiment with those hypotheses that the academic sphere has discarded or considered erroneous or impossible). ${ }^{13}$ In this way, Gasparini suggests (as Frederick does) that writers like Holmberg found in literature an appropriate space for the surreptitious questioning of the role of science in modern society, but also for the discussion of other forms of knowledge that aspired to enter the circle of academic approbation. ${ }^{14}$

The majority of the novel's critics, however, largely echo, without subjecting to any great scrutiny, Holmberg's own stated views on the role of fantastic literature in the divulgation of scientific ideas. Pablo Crash Solomonoff, for example, finds a harmonious unity in Holmberg's scientific and fictional activities, both of which are essentially forms of education: "Su proyecto pedagógico, así como literario, consistió en enseñar divirtiendo y en divertir(se) enseñando el amor al conocimiento" (His project, both pedagogical and literary, consisted in teaching by entertaining, and in entertaining [himself] by teaching a love of knowledge). ${ }^{15}$ Rachel Ferreira Haywood observes that Holmberg saw literature and science as "natural partners" in the process of developing a modern, scientifically informed nation. ${ }^{16}$ She concludes that Holmberg's choice of fantasy and science fiction as a form of address to his audience is fully justified as, borrowing the words of the novel's fictional editor, "Todos aquellos elementos que constituyen el conjunto, no habrían podido expresarse, tal vez, de otra manera" (All those elements that make up the whole could not, perhaps, have been expressed in any other way). ${ }^{17}$

There is another perspective, however, from which we may approach the surprising mixture of fantasy and science in Holmberg's work. My reading of the novel will place emphasis on its reflexive exploration of the power of fiction and fantasy in extending scientific knowledge to the masses and awakening their curiosity. This allows us to appreciate the ambivalence at the heart of Holmberg's fictional narratives, which ascribe a central role to fiction in the modernization and education of society, while simultaneously reflecting on its use to further the interests of those in power. Fiction might 
appear to play a key part in the extension of new ideas beyond scientific institutions, but Holmberg suspects that it may also, ultimately, buttress the nation's governing elite through the mystification of science and the pacification of the masses.

The failings of current-day Argentina that science-and fiction-must remedy are dramatized in Nic-Nac's visits to three cities on Mars: a utopian one, a dystopian one, and one that looks uncannily similar to the Buenos Aires of Holmberg's day. The utopian Sophopolis is a place of light and festivity, and its citizens are generous, egalitarian, and paragons of beauty and intelligence. Everyone is a student in Sophopolis, regardless of age or gender, and intellectuals from all nations are attracted to the city, working together to unravel nature's secrets. However, Sophopolis is tragically shackled to its dystopian sister city, Theopolis, a lugubrious and silent place, full of miserable religious hypocrites.

Sophopolis is governed by men of science and wisdom, whose leadership is not tainted by mercantilism, religious dogmatism, or political factionism. At the heart of the city is the Academy, a place of brilliant light, irradiated by "el magnífico resplandor de su ciencia" (the magnificent radiance of its science). ${ }^{18}$ As well as a forum for scholarly debate on scientific matters, it is also the supreme advisory body to the government and - we are told laterits primary legislative body. Membership of the Academy is open to anyone who desires to work for the happiness and well-being of all. The men of the Academy are fulfilled, obeying their human "mission" to study the harmony of the universe. This is not to say that the Academy is a place of perfect harmony itself, however: dissension and rivalry are common within its walls. Such are the necessary conditions of rigorous debate, and intelligent, just motions are always carried with unanimity.

When Nic-Nac and Seele move on to the capital city of the Nation of Aureliana (Argentina by another name), Holmberg switches from utopian to satirical mode. In place of Sophopolis's self-governance by rational debate and consensus, Nic-Nac is warned to expect "un pueblo siempre agitado y turbulento, a la vez que generoso" (a perpetually agitated and turbulent, if generous, people).$^{19}$ This quarrelsome city owes its divisiveness, we are told, to the heterogeneous mixture of nationalities and cultures among its immigrants. From this chaos wells up an in-fighting spirit that often leads to the eruption of violence and to those scenes of social protest that are "tan comunes en los pueblos que no han cimentado aún su organización interna” (so common in societies that have not consolidated their internal organization). ${ }^{20} \mathrm{~A}$ fast-dwindling national sentiment is powerless to check their "pa- 
siones mezquinas" (small-minded passions). ${ }^{21}$ We are far from the reign of reason in Sophopolis: here, the loudest voices are the least informed and the most stubborn. This generation, so different-Holmberg reminds us-from those that lived through Argentina's glorious history, can only find a source of inspiration and revitalization in a state of constant turmoil, in civil wars or international conflicts.

Holmberg repeatedly insists that the city's foreign inhabitants make up the greater part of the population, and observes that "en los semblantes de la aglomerada población no se podrían señalar los rasgos del tipo nacional, absorbido, devorado por el torbellino de un cosmopolitismo inexplicable" (in the faces of this amassed population one could not detect any recognizable national features, swallowed up, devoured by the whirlwind of an inexplicable cosmopolitanism). ${ }^{22}$ It is this heterogeneity that is quietly and effectively erased in the utopian Sophopolis. The city's distinctively academic culture and the harmony of its citizens are threatened by intruders from outside, however, who seek to stir up dissent and do not share its wholesome respect for life. Eventually, its tolerance of such intruders is its downfall, and a war provoked by Theopolis leaves both cities in flames.

Should we read Holmberg's text allegorically as the expression of hostility toward mass immigration? Holmberg does not employ the same invective against the new arrivals issued by many of his time, including Juan Bautista Alberdi, who complains in a letter appended to his Bases in I879-just four years after the publication of Viaje maravilloso - that his dictum of "gobernar es poblar" (to govern is to populate) would only hold force if immigrants were educated and civilized, and that otherwise, "poblar es apestar, corromper, degenerar, envenenar un país cuando en vez de poblarlo con la flor de la población trabajadora de la Europa, se le puebla con la basura de la Europa atrasada o menos culta" (to populate is to infect, to corrupt, to degenerate, to poison a country when instead of populating it with the cream of Europe's working population, it is populated with the trash of a backward and less cultured Europe). ${ }^{23}$ Holmberg's primary concern is not racial mixture but a lack of unity at the heart of the Argentine nation, which has no shared language, race, culture, or history on which to erect a national sensibility. Holmberg's concept of nationhood-like that of Sarmiento and Alberdi-rests on shared values of democracy, liberty, and education rather than on notions of territory. Thus not only social order but also the very concept of the nation is sorely threatened, in Holmberg's vision, by the massive influx of less educated immigrants and the concomitant problems of linguistic and cultural difference and social inequality. The nation is unable 
to function, as it should, as a space for reasoned debate, the exchange of views among equals, and the education of all.

Holmberg's publishing initiatives may be understood as a bid to reestablish a discursive community. His commitment to the public divulgation of scientific ideas led, among other projects, to the founding in 1878 (with Enrique Lynch Arribálzaga) of El naturalista argentino: Revista de historia natural (The Argentine Naturalist: Journal of Natural History). As Bruno explains, the publication represented a clear departure from the styles and concerns of other scientific journals of the period. It replaced the official lists and the publication of detailed studies, often written in foreign languages, with articles on a wider range of topics, "escritos en un registro ameno y didáctico que, en algunos casos, rozaba el relato de aventuras" (written in a readable, educational register that, in some cases, verged on the style of an adventure tale). ${ }^{24}$ The publication met some of the concerns of a new generation of Argentine natural scientists who were not content with the ways in which their discipline was developing; it made clear its intent to generate a space for the diffusion of scientific ideas beyond the closed world of academic specialists. $^{25}$

In many ways, Holmberg's fiction can be read as part of this broader mission to disseminate knowledge beyond the restricted spheres of the educated elites and to create an informed reading public. In the second issue of El naturalista argentino, Holmberg criticizes the lack of interest in public engagement shown by most of his fellow scientists (many of them brought over from Europe), and argues that

el pueblo, curioso por naturaleza, pero cuya curiosidad ha sido mal encaminada, necesita la forma animadísima de un Julio Verne, para poder escalar paso a paso las maravillas que la Naturaleza despliega en todas sus creaciones. ${ }^{26}$

the people, whose natural curiosity has been poorly directed, have need of the lively style of a Jules Verne, in order to approach, step by step, the marvels that Nature unfurls in all her creations.

Diana Cazaux argues that the divulgation of scientific ideas in Argentina in the second half of the nineteenth century and first half of the twentieth (1962-1942) closely corresponds to the "Anglo-Saxon tradition" identified by Sergi Cortiñas; this tradition, unlike the "Italian-Renaissance," "French," or "Prussian-German" models of scientific dissemination, is marked by the 
multiplication and diversification of channels of divulgation, including essays, novels, poetry, lectures, children's literature, press articles, and audiovisual texts. ${ }^{27}$ The periodical press was the most prominent site of literary and critical activity in late nineteenth-century Argentina, bringing together many of these different forms and genres. As Alejandra Laera observes, at this moment of vertiginous expansion, the sharing of this single space by high and popular literary texts has the effect of blurring differentiations between these two kinds of production and creating a diverse reading public. ${ }^{28}$

Most of the fictional works Holmberg published first appeared as folletines. In Viaje maravilloso, however, the framing narrative betrays Holmberg's ambivalence toward the use of the popular press for the dissemination of scientific ideas. In the prologue to Nic-Nac's account, Holmberg's fictional editor parodies the frivolity and sensationalism of the press, in which a much more serious political event (the discovery of a conspiracy to incite riots among workers ${ }^{29}$ is suddenly forgotten in the rush to publicize the story of Nic-Nac's journey to Mars. There is barely time to correct the ludicrous errors of its first hasty version of events before the entire story is dropped and forgotten within the space of two days, "lo que prueba una vez más cuán pasajeras son las grandezas humanas" (which proves yet again how fleeting are the glorious deeds of humankind)..$^{30}$ Against the odds, we are told, one press in the city decides to publish Nic-Nac's story. The text we are reading thus announces itself to be an attempt to counter the fickle interests of journalism and its reading public. Satirical and pragmatic at the same time, the narrator reflects that "en nuestros tiempos, las ideas serias no cumplen su destino sino envueltas en el manto de la fantasía" (in our time, serious ideas only accomplish their destiny if they are cloaked in the mantle of fantasy). ${ }^{31}$ The folletin's writer has got away with it: a little cloak-and-dagger work has slipped in a text of greater substance that might just challenge the superficial ideas of yellow-press readers.

Holmberg's mistrust of his own generic experiment-using serialized fiction to disseminate scientific ideas-becomes fully apparent in the epilogue, as the (fictional) editor of Nic-Nac's narrative steps in explicitly to tell its readers which parts of the narrative may be considered educational and which are mere flights of fantasy. The editor's hope that Nic-Nac's account may resolve "alguna cuestión importante" (some important issue") has ended in a most "iHorrible desengaño!" (horrible disillusionment). ${ }^{32}$ In many respects, the editor now appears to be somewhat skeptical about the version of events offered by Nic-Nac, who has now been diagnosed with 
"manía planetaria" (planetary mania) and thrown into a lunatic asylum. ${ }^{33}$ Reason, he concludes, cannot accept the story of Nic-Nac's journey: it was only the fantasy of a madman, whose feverish imagination it would be a kindness to relieve with a good cold shower.

Unlike most science fiction writers, Holmberg does not try to persuade the reader of the plausibility of the new worlds he imagines, and their credible basis in an extrapolation of today's science. Casting heavy doubt on Nic-Nac's story, the editor even criticizes its narrational style and sneers at "esa vaguedad indefinible de los conceptos" (the undefinable vagueness of its concepts)..$^{34}$ The deauthorizing framing narrative of Viaje maravilloso is highly unusual in the genre. It allows Holmberg to point to the unreceptive response of the institutions of his day to the paranormal and to potential new discoveries. Significantly, it also reveals Holmberg's concerns about the popular means of divulgation he has chosen: how are his readers to decide what is fantasy and what is science? Does the story of Nic-Nac really provide a counterpoint to the frivolity of the yellow press he criticizes, or does it simply fall into its own cheap sensationalism? Can the press be used as a tool for education if it is, like the press in Aureliana, "el eco nato de las opiniones del pueblo" (the true echo of the opinions of the people), ${ }^{35}$ simply perpetuating ignorant disputes rather than throwing greater light on them? Indeed, public and periodicals seem to be trapped in a circle of ignorance in Viaje maravilloso: when Seele is rejected as a charlatan, the narrator reminds us that the public always repeats the calumny of the popular press, and for this reason, "el pueblo no tiene, ni puede, ni debe tener opinión" (the people do not have an opinion, nor can they or should they). ${ }^{36}$ This hardly amounts to an endorsement, either of the capacity of the press or its readers, for the accurate reporting and reception of scientific ideas.

The relationship between fiction and science in Holmberg's novel marks a crucial point at which his work differs from that of both Verne and $\mathrm{H}$. G. Wells, his most significant European contemporaries. ${ }^{37}$ Arthur B. Evans contrasts Verne's use of fiction to teach science, on the one hand, with Wells's use of science to develop fiction, on the other. Verne's science fiction "presumes a predominantly pedagogical function" for scientific discourse, while in Wells, its aim is "more expositional: to facilitate plot progression, to help create special effects and reader estrangement, and to build verisimilitude ... allowing readers to focus more fully on the human ramifications of the story." 38 Holmberg's Viaje maravilloso has little, in the end, of the directly pedagogical spirit that informs Verne's fictional journeys. Neither does it use 
science to render his story more plausible or human. His novel carves out a third, more reflexive path, enquiring into the very nature of the relationship between fantasy and the divulgation of science.

This relationship is far from straightforward, as Holmberg's use of fantasy often sits uncomfortably with his pedagogical purpose. Enshrouding science in fantasy might arouse a sense of wonder and awe in the reader, but it also distances him or her from genuine scientific knowledge. On occasion, Holmberg arguably betrays a lesser interest in opening the doors of the scientific laboratory to the man on the street, and a greater one in preserving the pedagogical role of the scientific elite. In Viaje maravilloso, the religious ceremonies of Theopolis are cynically described as an effective attempt to hold the population in thrall: if no one understands the sacred music of the choirs, it is because otherwise "perderían su carácter eminentemente místico" (they would lose their eminently mystical nature). ${ }^{39}$ At times, however, Holmberg uses the same obfuscatory techniques, enveloping science in fantasy. This is one-less sympathetic-way in which we may read his recourse to the spirit-image: as Nic-Nac's journey is not reproducible through any technological means, his discoveries remain the preserve of the esoteric. When we are assured, in typical Romantic vein, that "el sueño es el eslabón que liga el espíritu humano con los grandes misterios de la Naturaleza" (the dream is the link that binds the human spirit to the great mysteries of $\mathrm{Na}$ ture),$^{40}$ this gives the ordinary reader little incentive or means to access those mysteries through methodical scientific observation. The use of fantasy to mystify the rational processes of scientific exploration is more evident in Holmberg's Dos partidos en lucha, given this novel's much greater focus on "hard" science. As Gasparini notes, the episode in which the mimosa specimen is "resurrected," brought back to life from a dried sample, "combina los pasos del método experimental con la iluminación de la magia, de lo revelado a unos pocos" (combines the procedures of experimental method with the illumination of magic, of that which is revealed only to a few). ${ }^{41}$

As the major Argentine newspapers of the period took it upon themselves to explain the latest scientific discoveries to their readers, Diana Cazaux suggests, the process of "translating" science actually reinforced the distance between scientists and the general public. Science took place in magical laboratories, with newspaper reporters invited in by the scientistmagician as special guests to appreciate his latest invention. ${ }^{42}$ As she notes,

Eso no hizo más que agregarle una capa de mágica y distancia a todo el asunto científico: en la medida en que el lector sentía que para 
llegar a la ciencia necesitaba un intermediario (y uno de peso, como un diario), la ciencia se hacía inaccesible, remota, imposible de transformar en propia. ${ }^{43}$

This only worked to add a layer of magic and distance to the scientific subject: to the extent that the reader felt that an intermediary (and an important one, like a newspaper) was needed to reach science, science became inaccessible, remote, impossible to make one's own.

This mystifying operation was reflected in the abandonment of a neutral, clear, and concise language to describe technological advances in favor of words such as "startling" or "surprising." ${ }^{44}$ This may have inspired awe and fascination in readers, but it also distanced them, requiring a magician (or in the case of Viaje maravilloso, a medium) to work the magic and explain it. Scientists became the priests of a new religion, holding the masses in thrall but denying them access to the holy of holies. Immediately after the quasi-magical resurrection of the sensitiva in Dos partidos en lucha, the scientist Grifitz explains: "Sirvo una doctrina científica: el darwinismo. Tarde o temprano llegará a ser una doctrina política y necesito cierto misterio en mi conducta" (I serve a scientific doctrine: Darwinism. Sooner or later it will become a political doctrine and I will need to reserve some mystery about my conduct). ${ }^{45}$ When science plays a role in political power, this cryptic statement suggests, a dose of mystification is highly effective.

Holmberg's ambivalence toward the use of fiction in educating the masses reaches new heights when he returns to novel-writing thirty years later with Olimpio Pitango de Monalia. Monalia is an earthly paradise whose intelligent citizens rule themselves with a universal respect for justice, leaving no need for political conflict. It is a meritocracy in which aptitude is the only criterion for taking on particular responsibilities. The nation has embraced progress, and the absence of a bureaucratic and convoluted legal system has allowed them to apply their collective brainpower to more useful ends. The utopia crumbles, however, when the political orator Olimpio Pitango persuades the people of Monalia that they cannot claim to be a modern nation as they lack political parties, institutions, and all the trappings of nineteenth-century Latin American nationalism: anthems, national heroes, committees, constitutions, parades, and official holidays. Fortunately for Olimpio Pitango, as Monalia is located somewhere off the coast of South America, there are numerous republics nearby that can provide excellent models of such things, and he travels to Buenos Aires to learn what he can. 
With the birth of political parties, Monalia loses all the benefits of its prior existence: peace, unity, well-being, and good relations with other nations. Its citizens become the unthinking, easily misled masses described in well-known studies of the time by Gustave Le Bon in France and José María Ramos Mejía in Argentina. Rendered with enough eloquence and brio, any nonsense spoken by their new masters of political rhetoric is sufficient to electrify the crowds of Monalia. They take on the characteristics of the masses analyzed by Le Bon (on whom Ramos Mejía drew heavily), for whom "No son, pues, los hechos mismos, en sí, los que afectan a la imaginación popular, sino más bien el modo como se presentan" (It is not the facts in themselves that impress the popular imagination, but the way in which they are presented). Instead, the masses respond to strong images that stir the spirit rather than the mind, Le Bon suggests, to the extent that "conocer el arte de impresionar la imaginación de las masas equivale a conocer el arte de gobernarlas" (to know how to act upon the imagination of the masses is to know how to govern them). ${ }^{46}$ Olimpio takes it upon himself to invent an entire past of venerable ruins for Monalia and somehow manages to convince the people of the truth of his wild fantasies, kindling in them a brash and unthinking nationalism.

And yet, while Holmberg mistrusts the vulnerability of the imagination to the wiles of political demagoguery, he insists that it remains the most crucial element in human intellectual development. If Monalia was a utopia, we are informed at the end of the novel that it was not a complete one: something had been neglected, and that was the art of storytelling. When news of the entrancing power of a particular storyteller reaches the government, Olimpio Pitango is anxious to know her secret. As she reminds him, "La facultad más necesaria para el hombre intelectual es la imaginación” (Imagination is the most necessary faculty in an intellectual). ${ }^{47}$ Without imagination, the storyteller argues, neither mathematicians, nor chemists, nor physicists could discover the marvels of the universe or tackle the problems of their disciplines; neither musicians, nor poets, nor painters could spread their creative wings; even history and philosophy find in the imagination what is lacking in the best archives and workshops. Imagination is the bedrock, not just of artistic creativity, but of all scientific and intellectual discovery.

Against the overwhelming positivism of his age, Holmberg asserts repeatedly in his fiction that reason will never extinguish the power of the imagination. As Olimpio Pitango eloquently explains,

Hay algo, Señora, Señores, que la Razón más poderosa no puede jamás destruir. Se derrumban las monarquías porque las repúblicas 
son la encarnación del más alto progreso político; se extinguen los pueblos porque la lucha por la vida los desaloja; se debilitan y mueren las religiones porque la razón las excluye; pero el sentimiento humano es la flor inmarcesible de la civilización y del progreso, porque está servido por la imaginación y la fantasía que son las energías motrices de la ciencia y de los descubrimientos. ${ }^{48}$

There is something, Madam, Gentlemen, that the most powerful Reason can never destroy. Monarchies fall because republics are the incarnation of the most advanced political progress; peoples vanish because the struggle for life evicts them; religions weaken and die because Reason rejects them; but human sentiment is the unfading flower of civilization and progress, because it is served by fantasy and the imagination, which are the motors of science and discovery.

Indeed, science and reason conspicuously fail in Olimpio Pitango. In an overzealous attempt to come up with some suitable ruins and relics of the past on which to found a nationalistic historical narrative-requisite, it would seem, for the construction of a modern nation - teams of paleographers triumphantly announce the discovery of ancient documents and are only later revealed to be completely mistaken. As Adriana Rodríguez Pérsico suggests in her analysis of the novel, literature and the imagination are afforded greater power than science in explaining reality: "Si la ciencia se equivoca, la literatura retiene la capacidad de actuar sobre la realidad, transformándola y aún inventándola" (If science is wrong, literature retains the capacity to act upon reality, transforming it and even inventing it). ${ }^{49}$

Thus while the recourse to fantasy and adventure genres—as in Verne's novels - certainly helped to popularize science in the late nineteenth century, Holmberg sounds a note of warning: fantasy may liberate the imagination of the masses and inspire a love of discovery and learning, but it may also be used to control and manipulate them. Fantasy lends itself to creating dazzling and obfuscating spectacles, working to shore up the power of the political and scientific elite at the same time as it purports to democratize science and expand knowledge among the masses. Science in Argentina after I 880 became increasingly about the regulation of the masses, with many advances in new technologies—such as fingerprinting — designed to contain and control. ${ }^{50}$ In Holmberg's Viaje maravilloso we glimpse an alternative view of science as imaginative discovery open to all, but it is clear that this vision was already under threat. In his early fiction the regulatory function 
of Argentina's new institutions is already stifling scientific curiosity and investigation; by the time we reach Olimpio Pitango de Monalia, scientists are falling over themselves in their attempts to serve a political program of rapid modernization and a nationalist manipulation of the masses.

In some ways, the ambivalence of Holmberg toward the transforming role of science in society makes him typical of his generation. As Oscar Terán observes, what was unusual about the modernizing process in Argentina is that its most zealous promoters were also those who expressed the deepest doubts about the consequences of their reforms. He argues that

en el seno de este sector que apuesta a la modernización y al progreso se desplieguen una serie de discursos complejos y correctivos que desearían cumplir el papel de la lanza mítica capaz de curar las heridas que ella misma produce. ${ }^{51}$

at the core of this social group that wagered everything on modernization and progress a series of complex and corrective discourses unfold, playing the role of the mythical lance, able to cure the wounds that it has itself inflicted.

It was this spirit, Terán suggests, that made Vicente Quesada lament the disappearance of the old farms and tall cypresses to make room for the railway, but at the same time to envision a future society that was enriched by European goods and customs..$^{52}$ Unlike Quesada or Miguel Cané, however, Holmberg expresses doubts not about the benefits of scientific progress, but about the receptivity of Argentina's new regulatory institutions toward the radically new and unorthodox ideas that fuel scientific advance. The central question that emerges in his fiction is how to disseminate such ideas. Fantasy, as we have seen, becomes for him the best and the worst of tools in this mission: powerful in stirring the imagination and inspiring a love of discovery and a fascination for the unknown, but potentially complicit in the subjugation of the masses to political demagoguery and the self-preserving interests of the elite. Holmberg conducts a self-critique of his own resort to fiction within the very pages of his scientific fantasies.

Rather than the education of the masses, it is perhaps the question of their governance that emerges as the most perturbing in Holmberg's fiction. Its reflexive exploration of fantastic literature reveals a darker side to this generation's utopian drive toward modernization and progress, suggesting that these projects were sometimes less about egalitarianism than about 
maintaining the status quo of the elite in the face of the increasing threat of Argentina’s burgeoning masses.

\section{El Eternauta: The Intellectual in War and Revolution}

Héctor Germán Oesterheld (1919-1978) studied Geology at the Universidad de Buenos Aires and went on to work in a mining laboratory. Meanwhile, he began to publish in the fields of children's literature and popular science, before starting to write scripts for comics in 1950. A number of his historietas—Rolo, el marciano adoptivo (1957), Sherlock Time (1958), and La guerra de los Antartes (1970, 1974) - are written with reference to the codes and conventions of the science fiction genre. It is El Eternauta, however, that was to become Argentina's most famous and well-loved science fiction comic series. Illustrated by Francisco Solano López, the first series ran from 1957 to I959 and tells the story of the extraterrestrial invasion of Earth and the efforts of a group of Argentines to repel the aliens and save the world. It has often been read as an allegory of imperialism, especially since the version released in 1969 , which was more overtly politicized. ${ }^{53}$ The second full series, another collaboration between Oesterheld and Solano López, began publication in 1976. Oesterheld, a member of Montoneros, a militant Peronist left-wing organization, produced the final installments in hiding during the dictatorship until his disappearance at the hands of the armed forces in $1977 .{ }^{54} \mathrm{By}$ that point, all four of Oesterheld's daughters and their husbands had also been abducted and killed or disappeared.

A graffiti mural at the Rivadavia railway station in Buenos Aires testifies to the extent to which Oesterheld's militant socialism and the tragic fate of his family have become inextricably bound up with the ways in which $E l$ Eternauta has been read. It draws a clear parallel between the fictional resistance mounted against the alien invasion and the failed left-wing struggle of the I970s, with the caption: "Tu lucha, lo mismo que la lucha de tus compańeros y de todos los hombres que combatieron contra la invasión, no ha sido en vano, aunque así te lo parezca" (Your battle, as well as the battle fought by your comrades and everyone who resisted the invasion, has not been in vain, although it may seem so to you).

Such readings are encouraged by the many autobiographical resonances of the second series. Oesterheld, who appears as himself in the story, joins the quest to overthrow the evil alien oppressors, putting down his pen to take up arms alongside his comrades, just as the scriptwriter himself did in 
reality. The various parallels evident between Oesterheld's life and work have severely circumscribed critical approaches, however, to the extent that they have coalesced around a single political interpretation of the text. Critics have even asserted that Oesterheld, who also wrote scripts for the Montoneros, so was immersed in political activity by the time of the second series that he simply turned it into a socialist manifesto. Juan Sasturain laments the programmatic qualities of El Eternauta II, suggesting that "el Oesterheld BURGUÉs escribe mejor que el comprometido" (the bourgeois Oesterheld writes better than the [politically] committed one). Pablo de Santis, for his part, complains that

la progresiva y extrema ideologización de sus historietas debilitó las ficciones de Oesterheld, cuyo textos eran objeto de una lectura política no sólo en términos generales, sino precisos, minuciosos. Los lectores buscaban, a modo de mensajes cifrados, retazos de información a través de los que se pudieran adivinar estrategias, discusiones, pasos futuros de la organización. ${ }^{55}$

the increasingly extreme incursion of ideology into his comics weakened Oesterheld's fictions, making his texts the object of political readings, not just of a general kind, but of a precise, painstaking sort. Readers were searching for coded messages, snippets of information that might lead them to guess at the organization's strategies, debates, and future steps.

In line with this approach, the first series has also been treated as a political allegory, retrospectively read as a premonition of authoritarian abuses to come in the form of the military regime it predated by some twenty years. ${ }^{56}$ Other analyses, more attentive to the text, have discovered in the bloodthirsty alien invasion of the first series an allegorical critique of Latin America's colonial past and neocolonial present.

As I will argue, these attempts to historicize Oesterheld's work generally anchor it to the wrong historical moment or fail to grasp the complexities of its ideological reflection. Different readings emerge when we place the two series within their specific political contexts-first, the years immediately following the fall of the first Peronist regime in 1955, and second, the most intense period of guerrilla activity and military repression in the "Dirty War" of 1976-77-and if we treat them as interventions in cultural debates within each period over the role of the intellectual in relation to politics and 
the masses. The texts that become visible under this lens are full of doubts and uncertainties, less a manifesto for socialist revolt than an exercise in self-critique, haunted by the prospect, not of authoritarian oppression, but of a destructive and bloody civil war. If Oesterheld's narratives of the clash between two cultures have been exclusively read as allegories for political struggle, we can also understand the battles they stage as interventions in the cultural politics of the relationship between the intellectual and the popular. As a highly reflexive and performative set of texts, El Eternauta stages its own appropriations of the popular. It does so in a way that challenges some of the paradigms we often use to theorize the relationship between elite and popular cultures, and brings into focus something of how this relationship is specifically worked out in Argentina and Latin America.

Turning first to the original series, the anti-imperialist reading is certainly given credence by the text's construction of urban space and its treatment of technology. Buenos Aires is first represented at the center of the alien invasion, but very quickly returns to its more usual position on the periphery of a battle being played out on a global scale. The survivors fight their way through the city to the alien headquarters, symbolically located in the Plaza del Congreso, the constitutional center of the Argentine Republic. A point of arrival in the drama, the image of the plaza under invasion (fig. I) is lent prominence by an oversized panel, and it is drawn with unusual detail. The careful use of radial lines and shadowing emphasizes the brightness of the globe installed by the aliens in the center of the Plaza and the mysterious nature of the power that emanates from it. An inset frame showing Juan's face-with furrowed brow and steely compressed lips-keeps at the fore the human response to the invasion, which is the primary concern of $E l$ Eternauta. The futuristic domes and transmitters contrast sharply with the realism with which the central monument is rendered, audaciously mapping science fiction topoi from the First World onto a clearly identifiable local space, far from the genre's metropolitan center. Throughout the first series, the city's most iconic squares and monuments, and even its bus routes, are traced with a startling cartographical accuracy. As Benjamin Fraser and Claudia Méndez argue, in agreement with Alfredo V. E. Rubione, it is this systematic indexing of emblematic spaces in Buenos Aires that made El Eternauta such a successful bid to found science fiction within a thoroughly national imaginary, rather than an imported one. ${ }^{57}$

However, this image of Buenos Aires, center stage in a global extraterrestrial invasion, soon gives way to another, more familiar scenario, in which the survivors realize they are simply onlookers—or worse, collateral victims—of 


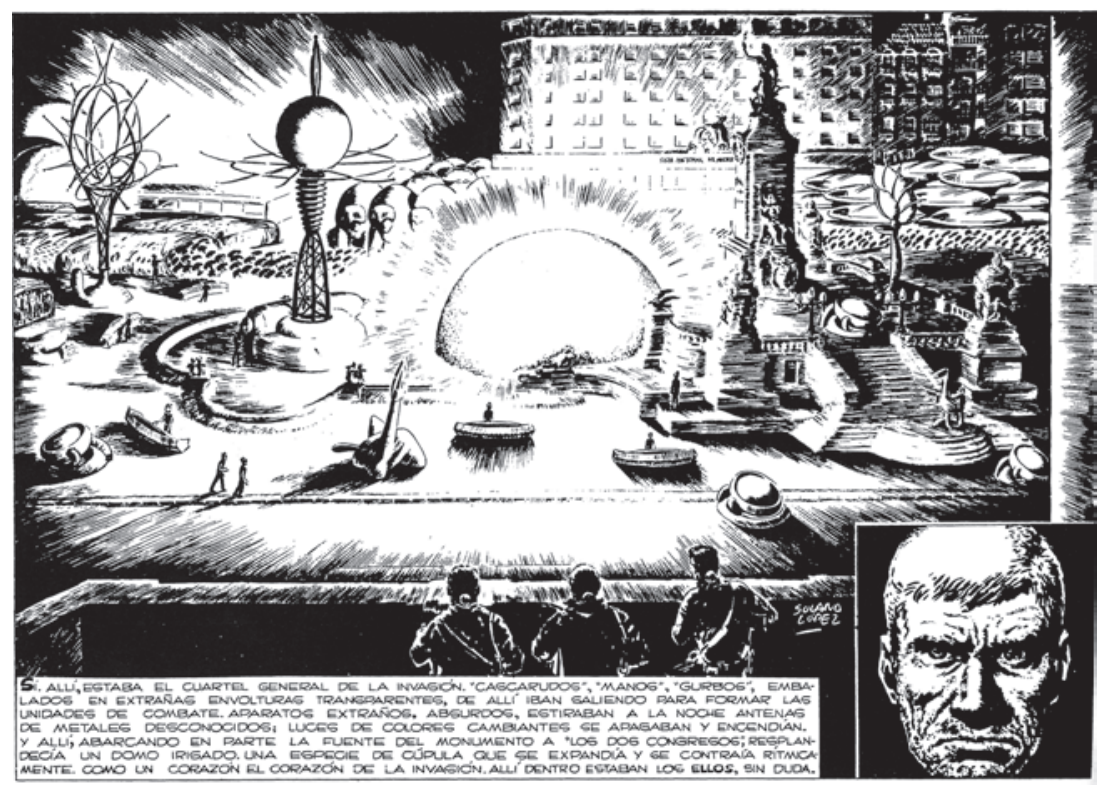

Fig. I. El Eternauta (Héctor Germán Oesterheld and Francisco Solano López, I955-57), 256

a much larger battle being fought over their heads, and in which the Argentines risk being blown up along with the aliens. In the 1969 version, First World indifference becomes downright betrayal, as the superpowers do a deal with the aliens, offering them total domination over South America in exchange for world peace.

El Eternauta represents science and technology as weapons that may be used with devastating effect against the powerless, but also turned to advantage against a more powerful enemy. The survivors are electronics enthusiasts, and Juan's workshop provides all the materials they need to improvise weapons and defenses. The practical, autodidactic, noninstitutional know-how of the Argentines is gleaned haphazardly from technical manuals and science fiction rather than studied systematically in advanced research laboratories, but it eventually proves more than a match for the colonizers' superior technology and organization. In the words of one critic, these Argentines could put a spaceship together with two screws and a piece of wire. ${ }^{58}$ Such representations clearly extol the tactics of the colonized as the arts of the bricoleur. But they also construct science and technology as a means of social mobility and interaction between classes. 
For Beatriz Sarlo, the new confidence in the opportunities provided by technology arising in 1920 B Buenos Aires receives its greatest fictional expression in the novels of Roberto Arlt. Like Arlt's, many of Oesterheld's characters are inventors and amateur scientists who, excluded from the "saberes prestigiosos" (prestigious forms of knowledge) of traditional, lettered culture, make use instead of "los saberes callejeros" (forms of street knowledge) listed by Sarlo, including literature in cheap editions and pirated translations, technology learned from manuals or technical magazines, catalogs of instruments and machines, informal institutes, and centers of the occult. As Sarlo comments, technology is the literature of the poor and a path to success that does not have to pass through higher education. ${ }^{59}$ Alongside practical uses of technology, science fiction itself is reflexively presented in El Eternauta as a common culture, a discursive space in which intellectuals and popular sectors can exchange ideas. It is a space in which the informal autodidacticism of the popular classes can often compete on an equal footing with institutional, elite forms of education. It is explained to us at several points that the reading of science fiction may compensate for a lack of formal training in science. The foundry worker, without the benefit of Juan's workshop or Favalli's scientific training, manages to construct the best isolation suit of them all, with the help of knowledge gained from futuristic novels and comics. ${ }^{60}$ The many correspondence courses and informal institutes offering such hobbistas the chance to improve their knowledge and skills were often advertised alongside science fiction comic series in the same magazines, ${ }^{61}$ highlighting the didactic aspect of science fiction.

At other points, however, El Eternauta acknowledges the divide that separates the intellectual from the man of action. Mosca, the historian who accompanies the impromptu resistance movement into battle with the aliens, is a comic and cowardly figure. He excuses his disappearance from the front line by explaining that "no se puede ser a la vez historiador y combatiente" (one can't be a historian and a soldier at the same time) ${ }^{62}$ and delights in his position of safety on the railway embankment, from where he is able to witness the battle taking place below. Juan, on the other hand, prides himself that he is "viviendo la historia, no escribiéndola" (living history, not writing it). ${ }^{63}$ Favalli, the text's clearest representative of a traditional intellectual-he is a physics teacher-wears spectacles and is quite portly, at risk of getting stuck in a subway tunnel during a dramatic escape.

The text's overall vision, however, is one in which "institutional" intellectuals, self-taught bricoleurs, and men of action work together to demonstrate the truth of Oesterheld's famous pronouncement in the prologue 
to the first series: that the real hero of the story is "un héroe colectivo, un grupo humano" (a collective hero, a group of humans). ${ }^{64}$ The characters, clearly differentiated by the illustrator with respect to their class origins, unite to save the nation. As has been noted, this vision is closely aligned with the cross-class alliance proposed by Arturo Frondizi to heal the deep rifts in Argentine society at the demise of the first Peronist regime in $1955 .{ }^{65}$ Perón's populism had left what Terán describes as an "abismo abierto" (gaping abyss) between the world of students and intellectuals on one hand and that of the workers on the other. ${ }^{66}$ Frondizi's proposal, had it been successful, would have united scientists, businessmen, and factory workers in a national front, providing a viable alternative to Peronism and giving a role to the intellectual elite without excluding the masses. As Silvia Sigal argues, Frondizi "encarnaba la posibilidad de establecer una pasarela viable entre intelectuales y política de masas" (embodied the possibility of building a viable passageway between intellectuals and mass politics), channeling both left-wing and nationalist thought, intellectuals and pueblo, into a single project of national unity. ${ }^{67}$ El Eternauta imagines a new world in which "doctores y pueblo" (PhDs and the populace) unite together with a common goal. Rather surprisingly, given the events of the period in question, the alliance even includes the military, who fight side by side with civilians to repel the invaders.

Nevertheless, some important roles are reserved in El Eternauta for the writer and intellectual. The industry workers owe their survival to the isolation suits constructed for them by the factory technician, explaining that "era un hombre leído: gracias a él estamos con vida" (he was a well-read man: thanks to him we are still alive). ${ }^{68}$ The intellectual possesses a knowledge of history, and at a crucial moment this delivers the survivors from a complacency that might have been fatal. If Mosca's position as a spectator perched above the action is mocked, Oesterheld's own is not: as the audience for Juan's tale from the future, he is the only person who can communicate the impending disaster to the world. To read the signs of the times, warn of danger, and denounce political repression: this is the contribution of the intellectual that is sketched out in the text's reflexive presentation of its author-narrator. In Oesterheld's version of the "intelectual comprometido" (politically committed intellectual) we can see a close engagement with prevailing discourses of the I950s and early I960s in Latin America. Heavily influenced by Sartre, these articulated a widespread conviction that the intellectual could, and should, become a principal agent for the transformation of society, and that discourses circulating in intellectual spheres held a 
profound significance for popular spheres. Crucially, this model allowed the intellectual to participate in politics while remaining within the intellectual sphere. ${ }^{69}$ By the time of the publication of the second series of El Eternauta in the mid-I970s, this was no longer a viable option.

The second series picks up the story exactly where the first left off, but we are soon catapulted via a time warp into a very different world. An unexplained extreme event-a natural disaster or the consequences of alien colonization?- - has returned Buenos Aires to the pampas, with the topography of the city now barely visible under the prodigious vegetation that has erased all traces of previous civilization. The human tribes have regressed to living in caves with little access to culture or technology and only a dim collective memory of previous civilization, as we are shown in the playful depiction of airplanes and tower blocks in their cave paintings. The nature of the struggle has changed: it is no longer a question of repelling invaders but of mounting resistance to an authoritarian regime that has kept the humans of the future in slavery, perhaps for centuries.

A shift is also evident in the role of the intellectual in relation to popular revolution. Oesterheld, again a character in his own fiction, is this time not simply a listener and storyteller but an active participant in the events: not a spectator watching from afar but both chronicler and guerrilla. The intellectual takes up the position of apprentice rather than teacher, learning new and more relevant skills in a radically altered world, including how to shoot with a bow and arrow. Oesterheld also learns the benefits of community and solidarity, which he begins to compare favorably with his previous, solitary existence as a writer. El Eternauta II can be seen to enact the increasing proximity of the intellectual to the masses he or she was previously seen as "representing" from afar. This move is closely documented in post-I968 France by Michel Foucault and Gilles Deleuze, among others. Foucault charts the replacement of the old model of the committed intellectual as "the spokesman of the universal" and the "conscience of us all" with a new understanding of the connections between theory and practice arising from the work of the "specific" rather than the "universal" intellectual. ${ }^{70}$ Similarly, Deleuze refutes the idea of a "theorising intellectual" as "a representing or representative consciousness": "Representation no longer exists; there's only action-theoretical action and practical action which serve as relays and form networks." 71

A movement from narration to action is clearly visible in the composition of the El Eternauta's panels. The first series makes much greater use of captions, and entire panels are often given over to the first-person narrative 


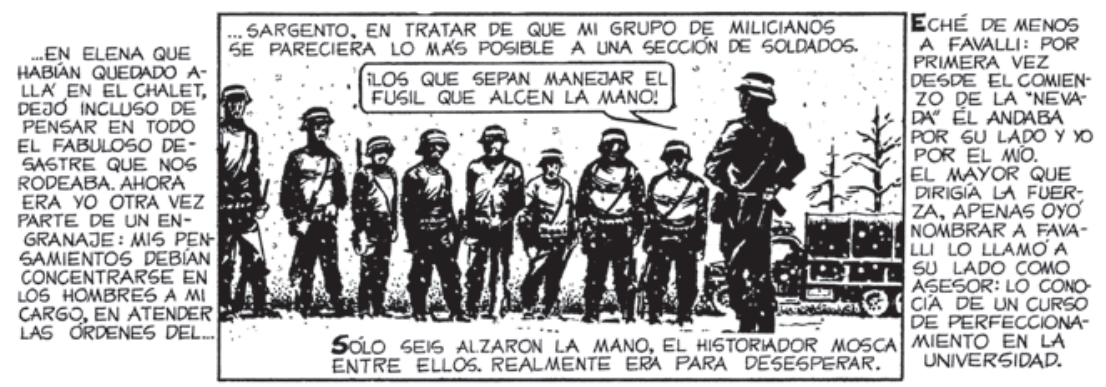

Fig. 2. El Eternauta (Héctor Germán Oesterheld and Francisco Solano López, I955-57), 75

voice (see fig. 2). We rarely lose sight of the fact that this is a story being recounted by Juan and mediated for us by Oesterheld, the scriptwriter, whose wrestings-back of the narration increase as El Eternauta reaches its climax and Oesterheld realizes that he is the only one able to warn the world of the impending invasion. The second series, with far fewer and briefer captions, often dissolves action and narration into one. As Oesterheld is both narrator and protagonist, there is no splitting of the narrative voice; this allows the illustrator to reproduce his thoughts and speech at many points within the panels themselves as thought-bubbles and speech-bubbles rather than captions beneath the action, creating a more fluid style with a faster reading pace. In comparison with the first series, words are accorded less space, crowded out by an action that does not permit room for logical analysis or explanation. This time there is only an arbitrary distinction between the narrative voice of the captions and the presentation of Oesterheld's thought within the panels: both are now always in the present tense, unlike in the first series (fig. 3). Again, the emphasis is on immediacy and action, rather than on mediation, reflection, and narrative coherence.

Terán points to a significant shift occurring toward the end of the I96os and the beginning of the 1970s, such that it is no longer the knowledge of the intellectual that legitimates his or her interventions in the political field, but the intellectual's political practice that legitimates his or her role as an intellectual. For Terán this constitutes "una especie de invasión, de canibalización de la política hacia el campo intelectual" (a kind of invasion, a cannibalization of the intellectual field by politics). ${ }^{72}$ The proximity between theory and practice observed by Foucault and Deleuze becomes in Argentina more of a subsumption of one by the other, given the intensity of the period's anti-intellectualism. This is fueled by Peronist populism and by the 

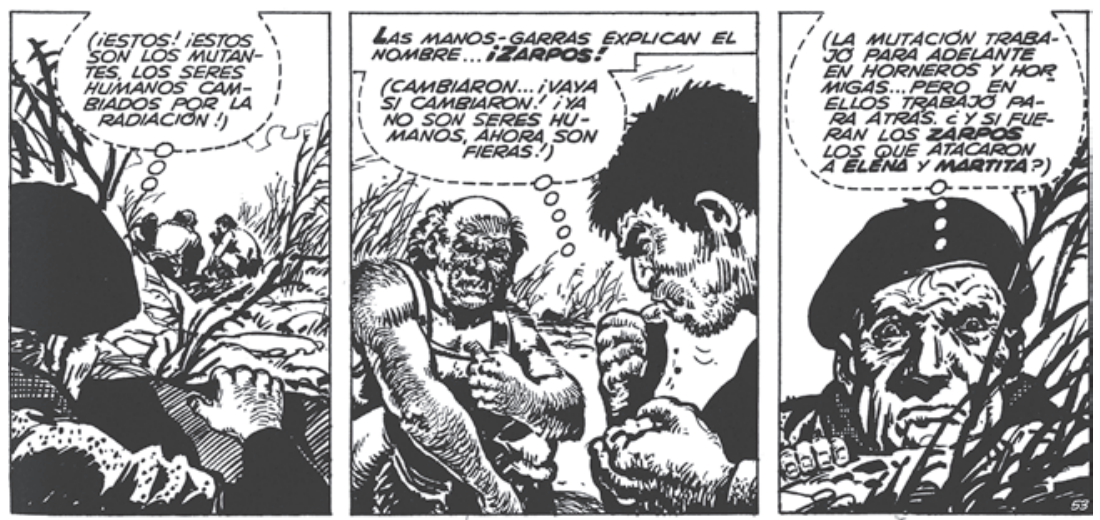

Fig. 3. El Eternauta II (Héctor Germán Oesterheld and Francisco Solano López, 1976-77), 57

crucial precedent of the 1959 Cuban Revolution, which appeared to have been conceived and executed without the need for theory. ${ }^{73}$ But it is also fed by a set of left-wing discourses that attempt to account for the deep and lasting appeal of Peronism to the masses by criticizing intellectuals for turning their back on the people. As Terán suggests, "En un período donde el antiintelectualismo alcanzaba estatura mundial, se vio nacer al más terrible de los antiintelectualismos: el de los intelectuales" (At a time at which antiintellectualism was gaining ground across the world, the most terrible of anti-intellectualisms was born: that of intellectuals themselves).$^{74}$ The emergence of such a marked polarization between elite culture and revolutionary action meant, as Claudia Gilman explains, that the badge of the "revolutionary intellectual" could be worn only by those who became directly involved in militancy or those who carved out a contradictory role for themselves by remaining in the intellectual field to censure the bourgeois complacency of other writers. ${ }^{75}$ To take an example from the pages of Crisis, the journal that perhaps more than any other charted the debates surrounding this new relationship, in 1974 Haroldo Conti (another writer disappeared by the military regime) explicitly questions the model of the revolutionary writer that had held sway since the i950s:

Ser revolucionario es una forma de vida, no una manera de escribir. No sé si un escritor por el hecho de que se lo proponga puede ser además un escritor revolucionario, es decir, puede producir una 
literatura revolucionaria. ... No sé qué sentido tiene que yo me proponga escribir una novela revolucionaria si ante todo no soy un revolucionario. ... no sé si basta con la decisión para lograr una literatura revolucionaria. En todo caso, si no lo consigue, al escritor le queda la oportunidad de ser un revolucionario a secas. Y esto, insisto, supone una conducta que implique toda su vida. Una conducta que en determinado momento incluso lo puede llevar a renunciar a la literatura, por lo menos como expresión individual. Entre nosotros hay compañeros que están en eso, lo cual redime nuestra tradición de teóricos y oportunistas. Compañeros que hacen y padecen la revolución, no que la utilizan. ${ }^{76}$

Being a revolutionary is a life-choice, not a writing style. I don't know if a writer can be a revolutionary writer, can write revolutionary literature, just by deciding to do so. . . . I don't know what writing a revolutionary novel would mean if I am not first and foremost a revolutionary. . . . I don't know if the mere decision to write revolutionary literature is enough. In any case, if it doesn't work, the writer is always left with the choice of becoming a revolutionary, plain and simple. And that, I must insist, is a decision that involves the whole of life, a decision that at some point might even lead him to give up literature, at least as an individual form of expression. There are comrades among us who have taken that decision, and their act redeems our lineage of theorists and opportunists. Comrades who work and suffer for the revolution, rather than using it.

Oesterheld chose the path of militancy. However, El Eternauta II hardly presents the ringing endorsement of this choice that we might expect, and that critics have tried to find. There is certainly no role for the intellectual as spokesman or teacher in the second series. This series makes none of the references common in the first to the importance of gaining knowledge through reading or applying technological know-how to forge practical solutions. Yet neither does it constitute a clear call to arms for intellectuals, expressing instead a profound disquiet over the mismatch between the intellectual and the new skills required of him. The decidedly paunchy Oesterheld is wholly unsuited to the physical rigors of survival in a changed world, struggling to keep pace with the others and to adapt to drastically altered circumstances. He is fully dependent on Juan and terrified when he finds himself alone, "como un niño pequeño sin la mano del padre" (like a small child without 
his parent's hand)..$^{77}$ Indeed, civilization and learning represent a distinct disadvantage in the business of survival in the regressive and brutal postinvasion world. Oesterheld comments with admiration on the atavistic instincts of Juan, "menos intelectual que yo" (less intellectual than I), which help him to spot enemies and find food. ${ }^{78}$

The end of the second series sees Oesterheld and Juan meeting again, this time in December 1976. Juan greets him with the words: "Sabía que vendrías, Germán. Te necesito" (I knew you’d come, Germán. I need you). ${ }^{79}$ What might initially be read as a vindication of Oesterheld's role- he is needed, after all-is an inescapably enigmatic statement: in what sense could Juan, with his exceptional powers, ideally equipped for militant action, possibly have a need for the bumbling writer whose inadequacies have often put the whole group in danger? This surprising vote of confidence has a hollow ring to it, conflicting with everything we have witnessed in the text. El Eternauta II paints a poignant picture of the emasculated intellectual adrift in a world of violence and barbarism in which his own skills are irrelevant. He is at best dependent on his more practical comrades, and at worst an obstacle to them. No amount of reading or thinking would have prepared the survivors to fight more effectively against the enemy: the only tools of use are physical prowess, clear leadership, solidarity, and a willingness to sacrifice everything for the cause. Interestingly, from the imagined communion of saberes populares and saberes cultos of series I we move to the saberes ocultos (occult forms of knowledge) Juan develops in the course of series II. There was nothing supernatural about the very ordinary heroes of the first series: their successes could have been repeated by any of the comic's readers with sufficient practical knowledge and a head for crises. Against the regime in El Eternauta II, however, Juan can only win by deploying a range of new skills to outwit the enemy: a superhuman level of fitness, an ability to predict the future, and a magical power to understand the workings of any machine in an instant.

Does this new role accorded to the supernatural betray a tacit disbelief in the possibility of revolutionary success within the realm of reality, or say something at least about the unattainability of the ideal of the revolutionary leader? Certainly, the recourse to saberes ocultos comes to fill the gap left by any guiding theory of revolution or book-learned knowledge. We are not presented with a marriage of theory and action but the subsumption of theory into an action that cannot afford to pause to examine the ethics of its decisions and lurches from one crisis to another. Far from a straightforward manifesto for militancy, the text becomes an expression of the pain of loss and of real doubt concerning the nature of armed struggle. If, as Roberto 
Von Sprecher observes, both Juan and the character Oesterheld echo at various points the Montonero doctrine of the sacrifice of the individual for the greater goal of collective freedom, ${ }^{80}$ such pronouncements take on a hollow ring within the narrative. Freedom and peace come at a great price: even the unwavering Juan reflects at the end that "costó mucho . . . demasiado" (it cost a great deal . . . too much), ${ }^{81}$ leaving the jury still out on whether the gains were worth it, in what is surely a reference not to alien battles but to the ethical uncertainties of a struggle much closer to home.

Even more surprisingly, perhaps, both series of El Eternauta refuse to construct the enemy as completely "other." The barbarism of the invaders is closely mirrored by that of the Argentines. For both, it is only the presence of a common enemy that stops them devouring each other and the Argentines are often described in bestial terms as wolves or wild beasts. The "Manos"-physiologically the closest alien species to humans-are treated with particular sympathy. Their death always brings a moment of sadness and regret to the Argentines, who realize how much they could have learned from them if they could only have become allies. In a more sinister vein, parallels are repeatedly drawn in the second series between Juan and the aliens, particularly at his moments of greatest ruthlessness. Oesterheld recoils from the same "mirada de trasmundo" (transworldly gaze) he observes in the eyes of both Juan and the "Mano"; when Juan dismisses the loss of human combatants—asking, "¿Qué importan unas cuantas vidas?" (What do a few lives matter?) — he becomes something less than human in our eyes. As Oesterheld reflects, sadly, for Juan "Los únicos iguales son los enemigos, los 'Ellos" (The only equals are the enemies, "Them"). ${ }^{82}$

How can we account for these expressions of sympathy and similarity across such a clear ideological divide if-according to most critical readings - the alien invaders are intended to represent either foreign imperialist regimes or the military dictatorship? It is my view that we can only do this by shifting our perception of the text's political imaginary, so that we understand the apocalyptic vision of El Eternauta to relate not primarily to a battle against foreign powers or a repressive government, but to the specter of civil war that haunts both periods of the text's production. We might detect, barely concealed beneath the fictional bombardment of the Plaza del Congreso, the impact of a real bombing, just a couple of years before and a few blocks away, carried out by the Argentine air force on civilians in the Plaza de Mayo on 16 June $1955 .{ }^{83}$ Repressed and displaced, this event and the instability that provoked and followed Perón's fall from power that year constitute the true scenario of fear in the text. 
This interpretation gains strength when we consider that the crisis with which the first series opens is not the threat of atomic radiation or of alien invasion but the absence of a functioning state. Favalli prioritizes the construction of weapons above all other survival tasks, saying: “¿Qué sabemos hasta dónde pueden llegar las ambiciones, los apetitos de otros, en una situación como ésta, donde no habrá policía ni autoridad que sirva de freno?” (Who knows how far the ambitions and appetites of others might lead them, in a situation like this, where there are neither police nor authorities to hold them back?). He predicts that "muy pronto esto será como la jungla . . . todos contra todos" (very soon this will be like a jungle ... everyone against everyone else). ${ }^{84}$ Modern civilization is but a delicate veneer held in place by the institutions of law enforcement: without these, man would quickly regress to the barbarism of his ancestors. In the struggle of the first series to imagine how and if citizens might cooperate in the absence of the state as a constraining force, we can read one of the pressing questions of the period immediately following Perón's defeat: what kinds of sociability and social organization will survive a crisis of such dimensions? The vision of a lawless barbarism destroying the fabric of society, that a friend might suddenly become an enemy, is far more terrifying in this text than the prospect of extinction at the hands of extraterrestrials. The first series, then, is more accurately read, not as a premonition of the cruelty of an authoritarian regime to come, but as a testament to the contemporary precariousness of the state and social relations at a time of great unrest.

In this context, Oesterheld's text performs a desire to bridge the gap, to intervene in order to reconnect estranged sectors of society. The desire for a genuine encounter with the Other ultimately dissolves, however, into a desire for the Other's recognition of the self: to hear that all-important "Te necesito." The fear of a descent into barbarism and the possibility of regression goes some way to explaining Oesterheld's insistent use of Darwinian paradigms, particularly in El Eternauta II. The most powerful of these paradigms, adaptation, also serves another purpose: that of staging the text's own relationship with popular culture. Adaptation is always the key to success for the Argentine survivors. And adaptability, just like the desire to bridge the gap, is central to how this text conceives of the relationship of the intellectual with popular culture. This particular conception provides the focus for the final part of my analysis.

Although we would unhesitatingly classify El Eternauta as a kind of textual production belonging to "popular culture," we have seen that it is overwhelmingly concerned, not with the experience of popular sectors of soci- 
ety, but with the role of the intellectual and political leader. Positioning the humans of the second series as genetically disadvantaged adds more glory to their eventual triumph, which is won by their solidarity and commitment to certain forms of social organization. However, it is abundantly clear that the pueblo of El Eternauta II does not have the capacity to lead the revolution on its own. It needs Juan, the only human who has mutated and thus acquired enhanced powers, to lead them in a successful revolt. The emphasis falls on the leader rather than the masses, in a way that moves us away from Oesterheld's clear formulation of the "héroe grupal" in the first series. What powers does the revolutionary leader need to bring the masses out of slavery? How will he be able to handle the loneliness of having to make difficult decisions? El Eternauta II is not narrated from the perspective of the masses, who remain largely undifferentiated and only capable of fighting their oppressors when organized by a leader who is of a different biological order.

The contrast is startling if we draw comparisons with another series written by Oesterheld in $1973-74$ for the Montonero publication El descamisado, a historical narrative of colonization and exploitation with a clear didactic purpose, published under the title Latinoamérica y el imperialismo: 450 años de guerra (Latin America and Imperialism: 450 Years of War). In the many battles fought by Latin Americans against colonizers and neocolonialists in this series, the pueblo is explicitly the protagonist of its own destiny and the victor in successful campaigns. In "El pueblo echa al invasor inglés" (The People Throw Out the English Invader), for example, Juan Paisano and Juan Esclavo fight "codo a codo con tantos otros Juanes" (side by side with so many other Juans) to defeat the foreign aggressors. ${ }^{85}$ Leaders, with or without extraordinary powers, are remarkable by their absence in this historieta. Surprisingly, perhaps, it is in the science fiction narrative of El Eternauta, rather than the historical accounts of Latinoamérica y el imperialismo, that Oesterheld confronts in a more realistic manner the complexities of leadership and mobilization for armed struggle.

The use of a popular genre in order to work through issues relating to the role of the intellectual fits comfortably within the central paradox of Argentine anti-intellectualism. Sarlo reminds us that the fervent antiintellectualism of the I960s and 1970s was birthed in heated intellectual debate and disseminated through written texts. Far from confining itself to spheres of action, the revolution was imagined and lived "bajo formas discursivas, textuales, librescas; . . . el imaginario político, lejos de configurarse contra lo letrado, recurría a una cultural ilustrada para articular impulsos, 
necesidades y creencias" (in discursive, textual, bookish forms; . . . the political imaginary, far from being configured against the learned, resorted to an erudite culture to articulate impulses, needs, and beliefs). ${ }^{86}$

Pierre Bourdieu provides us with a model for understanding this kind of usage of "the popular" to shore up the position of the intellectual, by moving away from a simplistic dichotomy between the intellectual sphere and that of the masses to show how hegemony may be exercised within those different spheres as well as across them. The "ambiguity" of the position writers and artists adopt with regard to bourgeois and popular sectors is a function, according to Bourdieu, of their contradictory status as "a dominated fraction of the dominant class." ${ }^{87}$ In 1970 Argentina, a considerable amount of prestige was to be gained by those intellectuals positioning themselves closest to the popular sphere, with the greatest and most notorious success gained here by Arturo Jauretche.

Terán argues that the politicization of intellectual and artistic spheres during the 1960 led to a reduction in their autonomy. ${ }^{88}$ It might be just as accurate to reverse the cause-and-effect relationship here and to see the politicization of intellectual and artistic spheres in this period as an expression of their weakness and relative lack of autonomy. This again is suggested by Bourdieu who, after reminding us that the "people" or the "popular" "is first of all one of the things at stake in the struggle between intellectuals," gives reasons for the aloof distance that the artistic sphere has generally maintained with respect to the popular (including self-help, popular medicine, spontaneity in different forms), which might threaten the professionalism of artists. He claims that "most of the types of discourse which have been or are produced in support of the 'people' come from producers occupying dominated positions in the field of production," and that "the moreor-less idealized 'people' is often a refuge against failure or exclusion." ${ }^{89} \mathrm{El}$ Eternauta's wholehearted embrace of the amateur, of self-help, and even of popular medicine could be seen to bear witness to the relative weakness of the artistic and intellectual spheres and their subsumption into the political sphere, where, as Bourdieu claims, speaking about or for the people is much more common. ${ }^{90}$

The question remains, however, of who is really invading whom. Sigal argues that we should not conclude that the autonomy of the intellectual field was destroyed in this period or that the figure of the intellectual becomes entirely reduced to a political function, because "la voluntad de someter lo cultural a lo político constituyó un ejemplo extremo de capacidad 
de elaboración cultural autónoma, erigiendo e imponiendo criterios políticos forjados por los agentes culturales mismos" (the will to subordinate the cultural to the political became an extreme example of the capacity of the cultural for autonomous development, constructing and imposing political rules and codes forged by cultural practitioners themselves). ${ }^{91}$ This period demonstrates the capacity of the cultural sphere to adapt to changed circumstances and to make use of them to forge new identities and discourses. The use of the "popular" becomes a survival strategy serving an intellectual end, combining theory and practice in a way that would allow intellectuals to play a significant part in the dissemination of political ideas, as long as they continued to subject themselves to abasement and self-critique. Returning to El Eternauta's endorsement of adaptability as the key to survival, if anything it is intellectuals who have proved themselves more adaptable than the masses to changing political circumstances, acquiring greater resources and skills through the appropriation of popular genres and discourses. With respect to cultural production at least, it is clear that elite culture came out on top, borrowing successfully from popular cultural forms from the r970s onward in particular, in order to revitalize its own art forms.

However, claims of the disingenuousness of the intellectual's use of the popular, within an ongoing exercise of hegemony, mark the point at which Bourdieu's theorizations of this relationship may obscure, rather than illuminate, the dynamics of this particular moment in Argentine cultural and political history. Bourdieu's terms lead us to suspect something cynical and premeditated in the intellectual's use of "the people," a kind of bad faith, or at least an unknowing and complacent self-seeking. El Eternauta gives us instead a glimpse of what it is like to be caught up in this struggle: the pain of loss, of being forced to adapt to a new world, of doing battle in the context of almost certain failure. Even Bourdieu's theorizations of the fractured operation of hegemony within, as well as across, different spheres is still not fully adequate to account for what happens when speaking for becomes militating alongside, when the search for a common culture involves not selfinterest but self-sacrifice, and when appropriating the popular also means disappropriating the intellectual.

In El Eternauta's reflexivity we may perhaps appreciate a different role for the intellectual, one of greater integrity and humility, but one that does not make the mistake of undervaluing the importance of the part the intellectual may play in challenging dogmas, complicating the dangerously oversimplified and refusing to allow thought to settle into rigid paradigms. This kind of role is sketched out by Foucault: 
The role of the intellectual is not to tell others what they have to do. By what right would he do so? .. . The work of an intellectual is not to shape others' political will; it is, through the analyses that he carries out in his own field, to question over and over again what is postulated as self-evident, to disturb people's mental habits, the way they do and think things, to dissipate what is familiar and accepted, to reexamine rules and institutions and on the basis of this re-problematization (in which he carries out his specific task as an intellectual) to participate in the formation of a political will (in which he has his role as citizen to play). ${ }^{92}$

Operating in this way, El Eternauta effectively answers back to those critics who have sought too eagerly to harness it to a particular political vision. Its reflexivity does not (or does not simply) lead to a narcissistic performance, but bears poignant witness to the difficult encounter between intellectuals and the masses even at a time of apparent rapprochement, an encounter so fraught with misapprehensions and false projections that it would find a ready analogue in a science fiction narrative of interplanetary invasion.

\section{Conclusion: Materialism, between Darwin and Marx}

The iconic image of Juan Salvo in spacesuit striding through the snow to fight off an alien invasion affords a rich form of symbolic capital that has been exploited in different ways since the publication of Oesterheld's El Eternauta. In 20IO, a modified "Nestornauta" illustration, with Néstor Kirchner's visage replacing Juan's, was used to promote a Kirchnerist youth convention in Luna Park. The hero's image has come to evoke a range of popularist struggles against authoritarianism and neocolonial interests, here making a powerful contribution to the Kirchners' active mobilization of left-wing Peronist discourses of the 1970s. ${ }^{93}$ The story of Holmberg's Viaje maravilloso del señor Nic-Nac al planeta Marte has also been recently revived in the form of a graphic novel, by Leonardo Kuntscher and Santiago Miret. Interestingly, Kuntscher takes the decision to set the story five years later, in I880, during the civil war that marked the last armed struggle against the federalization of the nation. He expands the framing story and brings it back on repeated occasions into the main narrative of Nic-Nac's journey, turning Holmberg's brief initial sketch of a turbulent society into a more sustained 
treatment of a nation at war. The close relationship between science and political power is also enhanced, as Nic-Nac complains that a research trip abroad would never be financed: "El gobierno sólo gasta en expediciones de conquista, para marcar territorio" (The government only funds conquest expeditions, to mark out territory). ${ }^{94}$

These texts, both in their original incarnations and in their extended lives in other media, have become sites for working through a series of questions concerning the relationship between elite and popular sectors in Argentine society: the perceived need to unite new masses of immigrant workers around a sense of national identity so that they did not endanger bourgeois social and cultural values, the threat of civil war along class lines, and the problematic role of the intellectual in popular revolution. Both Holmberg and Oesterheld chose to confront these issues reflexively within their work and to use the popular press - in the form of serialized novels and comics - as a vehicle for their political views. Science emerges as an important catalyst for these debates: as a burgeoning new field of knowledge in late nineteenth-century Argentina, with the power to propel the whole nation into modernity or to fragment society still further along educational and class divides (Holmberg), or to provide a materialist framework for understanding human evolution and class struggle (Oesterheld).

In Holmberg's literary prose we may detect a materialist worldview that would go on to be dominant in twentieth-century science fiction in Argentina. In these early science fiction texts, however, a scientific-materialist (Darwinian) understanding of nature and of the role of humans within it struggles to establish its credibility against spiritist interpretations, and shared discourses often reveal the overlaps between two approaches that had yet to become fully distinct from each other. As Soledad Quereilhac observes, many narratives of the time were focused on what she terms a "curious oxymoron," namely, the attempt to conceive of the spiritual in materialist terms. ${ }^{95}$ Holmberg's fiction frequently dramatizes the debate between materialism and spiritism, espousing opposing views or imagining new ways to reconcile them. His story "Horacio Kalibang o los autómatas" (I879) affords us perhaps the clearest example of the tendency Quereilhac notes. The solidly materialist Burgermeister cannot but agree with the vision set out before him, in which the mind and the soul are the sum of physical forces and chemical elements, made of the same stuff as the rest of nature:

¿Qué es el cerebro sino una gran máquina, cuyos exquisitos resortes se mueven en virtud de impulsos mil y mil veces transformados? ¿Qué 
es el alma sino el conjunto de esas funciones mecánicas? La acción físicoquímica del estímulo sanguíneo, la transmisión nerviosa, la idea, en su carácter imponderable e intangible, no son sino estados diversos de una misma materia, una y simple en sustancia, inmortal y eternamente indiferente, al obedecer a la fatalidad de sus permutaciones, que producen un infusorio, un hongo, un reptil, un árbol, un hombre, un pensamiento, en fin. ${ }^{96}$

What is the brain if not a great machine, whose exquisite springs move by virtue of impulses that have undergone a thousand transformations? What is the soul if not the ensemble of those mechanical functions? The physicochemical action deriving from the stimulus of the blood, nervous transmission, the idea, in its imponderable and intangible form, are only diverse states of the same matter, one and simple in substance, immortal and eternally indifferent, obeying the destiny of its permutations, which produce an amoeba, a fungus, a reptile, a tree, a man, a thought, in short.

This understanding has much in common, as we will see, with the posthuman discourses mobilized by more contemporary writers such as Marcelo Cohen (see chapter 5). In Viaje maravilloso, however, Holmberg insists that human intelligence transcends the material, and that "hay un más allá de las necesidades vegetativas, un más allá que nos abre las puertas de la eternidad y del espacio" (there lies a realm beyond vegetative necessities, a beyond that opens up for us the gates of eternity and of space)..$^{97}$ In Holmberg's hands, literature becomes both an instrument for the divulgation of modern (positivist) scientific ideas, and a space in which the mysteries of art and nature are preserved. "Hay cosas que no se explican, porque no se puede ni se debe explicarlas" (There are things that are not explained, because one cannot and should not explain them), we are reminded in "El ruiseñor y el artista" (I876). ${ }^{98}$

As science fiction began a process of consolidation as a genre, both in Argentina and elsewhere, it was the materialist thrust of its explanations that was to define the genre. In Oesterheld's El Eternauta II, for example, the superhuman powers acquired by Juan, including telepathic insights, are carefully attributed to a genetic mutation suffered as a result of an enormous dose of radiation. Oesterheld's vision is one that embeds the human thoroughly within nature: all species, human and animal, are subject to a similar genetic mutation; the cave-dwellers enter the futuristic fortress of their oppressors encouraged by a number of natural omens, such as an owl escaping 
from a bat; and the postrevolutionary, utopian society is characterized by a close, productive relationship with the land. Importantly, however-and this is fully consonant with Oesterheld's Marxist understanding of the history of human labor-technology is not opposed to nature: this new society is eager to (re)develop new machines, such as a steam-powered plow, in order to make their labor more productive. It is not technology that is responsible for human alienation from the land but exploitative forms of labor. As Marx wrote,

Technology reveals the active relation of man to nature, the direct process of the production of his life, and thereby it also lays bare the process of the production of the social relations of his life, and the mental conceptions that flow from those relations. ${ }^{99}$

This understanding of the relationships among humans, technology, and nature, in which humans are involved in active, material transactions with the natural environment, and the evolution of tool-use determines the evolution of human society, becomes central to the more recent forms of materialist thought developed by Bernard Stiegler and others, the focus of discussion in chapters 3 and 4 . While remaining committed to Darwin's materialist approach, these newer expressions also move beyond the model of natural selection proposed by Darwin to explore forms of what has become known as gene-culture coevolution. As we will see, this dual emphasis on genetic and cultural inheritance consolidates a line of science fiction that employs metafictional techniques at the service of materialist thought. 


\section{2 / Mediation and Materiality in Graphic Fiction}

With the world's population decimated by nuclear war and all but extinguished by a mutated AIDS virus, the survivors have taken refuge in a colossal skyscraper built in the remote Tierra del Fuego. Inside, they are so rigidly segregated that they have no opportunity to discover the terrifying truth: that the lower classes of society are being recycled as food for the higher ones. After being drained of their life forces, they are mashed to a pulp in a huge machine before emerging on a conveyor belt, reformed into neat cubes and ready for packaging. The machine's quite unnecessary number of ducts and grinders, together with the sound effects of gory squelches (fig. 4), point with a self-parodying humor to the common use of visual hyperbole in comics. Excess and exaggeration are often evident in Ministerio (Ricardo Barreiro and Francisco Solano López, 1986), contrasting powerfully with the comic's more somber exploration of state repression and memory within postdictatorship Argentina. ${ }^{1}$

Such self-parody has been typical of graphic fiction since the emergence of underground comix in the 1960s, such as Wimmen's Comix and Robert Crumb's $Z a p$ (1968), and has taken on a particular force in Argentine comics since the r980s. ${ }^{2}$ Indeed, the comics medium is often strongly characterized by reflexivity and a ludic interrogation of its own conventions. As HansChristian Christiansen suggests, "Comics have inherently unique features which would tend to promote formal play of a potentially disruptive kind: for instance the anti-naturalistic iconography and the deconstructive or conflictual play between word and picture and picture-sequence." ${ }^{3}$ While 


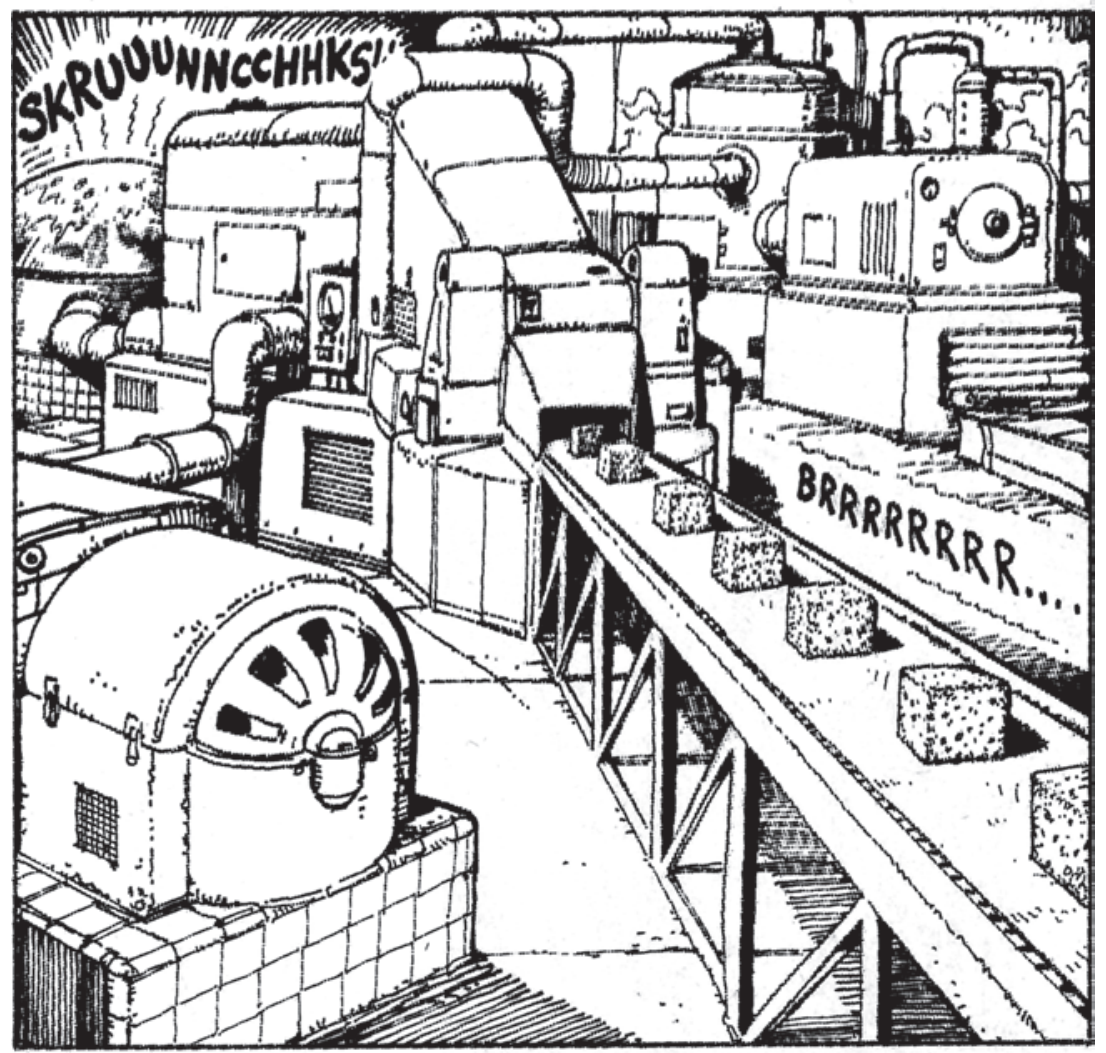

Fig. 4. Ministerio (Ricardo Barreiro and Francisco Solano López, I986), 6I

an important number of comics, especially in Argentina, have dedicated themselves to the task of adapting literary or cinematic texts, ${ }^{4}$ or to the recreation of classic comics for another market or generation, intertextual and intermedial play are by no means limited to such enterprises. The recurrent citations, resignifications, and remediations of graphic fiction become even more prevalent in science fiction and fantasy genres, given their frequent use of common narrative topoi and "shared universes," in which more than one writer contributes to the construction of a fictional world.

Many would agree with Manfred Pfister that intertextuality is the "central constructional principle" of postmodernism. ${ }^{5}$ Deployed as an antimimetic device, it works to blur the boundary between text and world, suggesting that reality is simply a linguistic construction and that texts refer 
only to other texts in a giddy mise en abyme of self-reference. In this chapter I will test out the hypothesis that comic-book reflexivity does not primarily engage in intertextual and reflexive play in order to point to the illusory nature of what we take for reality, but instead to draw attention to the material qualities of its medium. In other words, the kind of reflexivity we encounter in graphic fiction ultimately reveals not the immateriality of the world so much as the materiality of the text, and of drawing, writing, and reading as embodied practices that situate us within the material world. This reflexivity does not necessarily, therefore, lead to a postmodern crisis in representation of the kind Hans Bertens describes as "a deeply felt loss of faith in our ability to represent the real."' Instead, as I will argue, it acts to recuperate mediation and translation as defining features of graphic fiction and crucial to its self-positioning as a map, manual, compendium, or digest to aid its readers in their negotiation of the material world beyond the text.

My discussion will focus on the use of reflexivity in a selection of science fiction comics by the scriptwriter Ricardo Barreiro (1949-1999), serialized in magazines between the late 1970 and the late 1980 and later collated in book form. Barreiro was one of Argentina's premier scriptwriters, eclipsed only by Oesterheld, and he worked in partnership with many of the country's most talented illustrators, including Francisco Solano López, Juan Zanotto, Eduardo Risso, and Juan Giménez. The first part of this chapter will investigate how the comic medium is exploited in Barreiro's work to give form to the experience of time and space within the modern city, and to evoke the comic's particular capacity to blend myth and materiality. Here I will draw on recent work by Jens Balzer and André Suhr, among others, who take inspiration from Walter Benjamin's urban writings to ask whether the comic medium has "special competences for capturing urban space and city life," Latin American city.

The second part of the chapter will engage in a more critical fashion with the Benjaminian orientation of recent comics theory and criticism, and specifically with a line of enquiry I find very suggestive, at least in part because it highlights the materialist impetus of comic-book reflexivity. I refer to Jared Gardner's work on comics as a form of (Benjaminian) archive. His insights have been extended by Jörn Enns, again with recourse to Benjamin, who argues that if graphic fiction takes on the form of the archive, it is "also because it reflects the experience of the modern city, which is itself also an archive." With reference to Barreiro's texts, I will explore what the metaphor of the archive might reveal or conceal about the construction of 
knowledge in graphic fiction. I will propose some alternative figures thattaken together-might account more fully for the reflexive practices of these comics, as well as the strategies employed more generally by graphic fiction to define and differentiate itself in relation to other forms of literary and visual media.

My analysis throughout will draw attention to the tension between mythology and materialism in these comics' representation of the city. Although they appear in some ways to inscribe themselves within the literary tradition of fantasy, self-reflexivity, and philosophical idealism epitomized by Borges's fiction, their commitment to the material dimensions of both urban experience and the text itself points to an alternative way in which we might read their metafictionality: not as evidence of a postmodern flight into textuality but primarily as a exploration of the materiality of graphic fiction as a medium, and its particular capacity to reflect the city's own fusion of the mythical and the material.

\section{Myth and Materiality in the Neoliberal City: Ricardo Barreiro's Science Fiction Comics}

In their introduction to an excellent compilation of essays, Comics and the City: Urban Space in Print, Picture, and Sequence, Jörn Ahrens and Arno Meteling describe the "fundamental connection" between the rise of comics and the emergence of mass societies and mass cultures at the turn of the twentieth century, as comics flourished in tandem with modern newspapers. ${ }^{9}$ This relationship is not merely historical or commercial, but also aesthetic, they argue: comics have a particular facility for capturing urban space and city life, producing similar modes of perception and promoting "the loose and moving gaze of the urban flaneur." ${ }^{10}$ The structural similarities between comics and the city have inspired a recent wave of scholarship on comic form that has succeeded in uniting formalist and semiotic approaches (such as those developed in foundational works by Scott McCloud and Thierry Groensteen in the 1990s) ${ }^{11}$ with the social and economic critique of modernity.

Although there is emphatic agreement among scholars that the spatial and narrative fragmentation of comics powerfully conjures up the experience of urban life, contradictions begin to emerge in the detail. André Suhr directs his attention to how comic form may mimic the fragmentary, fleeting, and finite nature of our perception as we walk through the streets of a city, proposing that the frames of comics mimic those frames that feature 
prominently along our way through the city: "Windows, openings, doorways, street entrances - they all frame our view, putting things into the picture and others out of it, just as comics' frames do."12 Similarly, Jens Balzer suggests that "comics are part of an aesthetics that can consume the image of the 'whole' only in its disharmony." Ahrens and Meteling, on the other hand, ask: "Does the spatial inertia of the sequences in contrast to film, video, or television result in retardation in order to ease the saturation that has been attributed to the big city since 1900?" 13 In other words, do the static images of comics actually provide relief from the speed and tumultuous disorder with which texts and images bombard us in the city, allowing the reader to absorb them at their own pace?

This contradiction is, of course, at the root of art's defamiliarization of perception, through which it simultaneously registers experience and encourages us to reflect critically upon it. It is a contradiction Graeme Gilloch finds to be particularly marked in Benjamin's texts on the city, which are "symptomatic of, yet resistant to, modernity. The Passagenarbeit incorporates the experiences of modern life in order to negate them. Writing the city breaks its spell." ${ }^{14}$ Benjamin—like many others of his time, including Laszló Moholy-Nagy and Jean Epstein—grasped the vast potential in film to defamiliarize temporal and spatial experience, drawing on the camera's resources "for swooping and rising, disrupting and isolating, stretching or compressing a sequence, enlarging or reducing an object." The use of slowmotion sequences and close-up shots brings to light "entirely new structures of matter," thereby altering our perception of the city. ${ }^{15}$ For Benjamin, however, the revolutionary potential of photography would not be fully realized until the writer took it up to recast conventional literary form, breaking down "the barrier between writing and image."16 This new medium would tap into the energy with which advertising had begun to flood the streets of the modern city with new constellations of texts and images, in its own recastings of the relationship between art and technology. ${ }^{17}$ "Without ever knowing its name," Gardner suggests, "the writing Benjamin is calling for in the 1930 is clearly the comic." 18 It is with this conviction that scholars working on comics have recently returned to Benjamin's writings on the city. The sketches, aphorisms, and brief commentaries that comprise his Arcades Project (1927-40) evince the ceaseless flux, the assault on the senses, and the dissolution of fixed perspectives that characterize urban experience, and that may also be powerfully expressed in the temporal and spatial discontinuities of graphic fiction.

In the discussion that follows of two science fiction comics scripted by 
Barreiro, I will supplement Benjamin's observations with those of the urban theorist Néstor García Canclini to consider how graphic fiction may capture the specific characteristics of the modern Latin American city. Both theorists share an understanding of the tensions between the mythological and the material in the city, which is composed of images, dreams, and memories as much as of bricks and concrete. This vision permeates the representation of the city in Ciudad (Barreiro and Juan Giménez, I982), ${ }^{19}$ in which characters are trapped within an infinite labyrinth that is implacably solid in its physical dimensions but also subject to the constant metamorphoses proper to myth. In Ciudad and a later comic, Cain (with Eduardo Risso, 1988), ${ }^{20}$ Barreiro also brings into focus other tensions that have come to define urban experience in Latin America: the conflict between rationalist planning and unplanned growth on a vast scale, the coexistence of multiple temporalities, and the extremes of totalitarianism and a decentered, weakened power of the state under neoliberalism. Barreiro and his illustrators consistently exploit the material and formal resources of graphic fiction to construct the comic as an exemplary medium through which to explore late twentieth-century urban experience in Latin America.

In Ciudad, the protagonists have slipped into another universe from which they cannot escape: a perilous, precarious place that, although presented in a fantastical key, bears many of the hallmarks of the modern (Latin American) city. The comic's unforgiving perpendiculars and outsized facades portray a city that has not been built on a human scale. It is "una metrópolis monstruosa, infinita y sin nombre" (a monstrous metropolis, infinite and nameless) and "un laberinto infernal" (an infernal labyrinth). ${ }^{21}$ Alternating long shots and close-ups, bird's-eye and worm's-eye perspectives emphasize the vulnerability of its inhabitants, lost in the monumental architecture of its streets. This effect is heightened at times by the use of three-point perspective (see fig. 5), coupled here with a curved horizontal line mimicking the distortion of a fish-eye lens to lend a delirious tilt and reel to the towers stretching upward above. Both Ciudad and Ministerio give voice, at least in part, to modern anxieties about the development of the ultrarational, bureaucratic city, often figured as a prison or a labyrinth. Ministerio in particular echoes the fears expressed by Georg Simmel in The Metropolis and Mental Life (1903), in which he laments the risk to the individual of "being levelled, swallowed up in the social-technological mechanism." ${ }^{22}$ Quite literally, here, citizens are sucked into Solano López's infernal machine and spewed out as anonymized cubes of biological material that provide the nutrition necessary to maintain society's strict hierarchies (see fig. 4 above). 


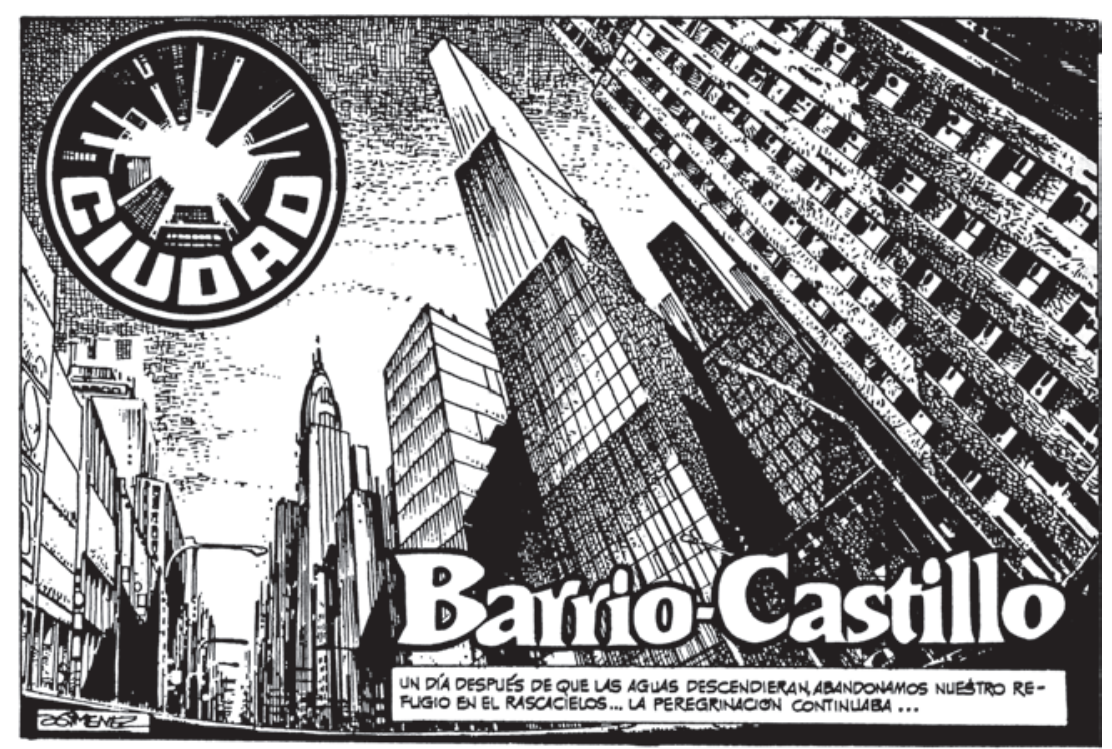

Fig. 5. Ciudad (Ricardo Barreiro and Juan Giménez, 1982), 96

While Ciudad bears witness in a similar manner to the danger that the rational city represents to individual safety and liberty, it also immerses us in a city that continually transgresses its bounds and threatens to dissolve order and form into anarchy and excess. It highlights the tension between the rigid, prison-like grid of the planned metropolis and our much more subjective experience of time and space in the city. Through repeated transgressions of the comic's own conventional grid format (its separation into panels and gutters), Barreiro and Giménez evoke an experience of moving through the city that confounds any strict topography. Figure 6 illustrates Jean's long walk home, which stretches out impossibly until he finds himself in the parallel universe of the infinite city. The page encourages a reading that is both simultaneous and linear, which grasps the whole theme (walking), represented by the dominating central figure of Jean, as well as following the narratives of the individual frames. It therefore pulls us out of time, mimicking Jean's own separation from objective time. This is reinforced by the repeated superimposition of his figure in different sizes on some of the panels, suggesting a splitting of consciousness as he begins to enter a different dimension.

The spatial coordinates of the city itself are never defined in Ciudad: it 


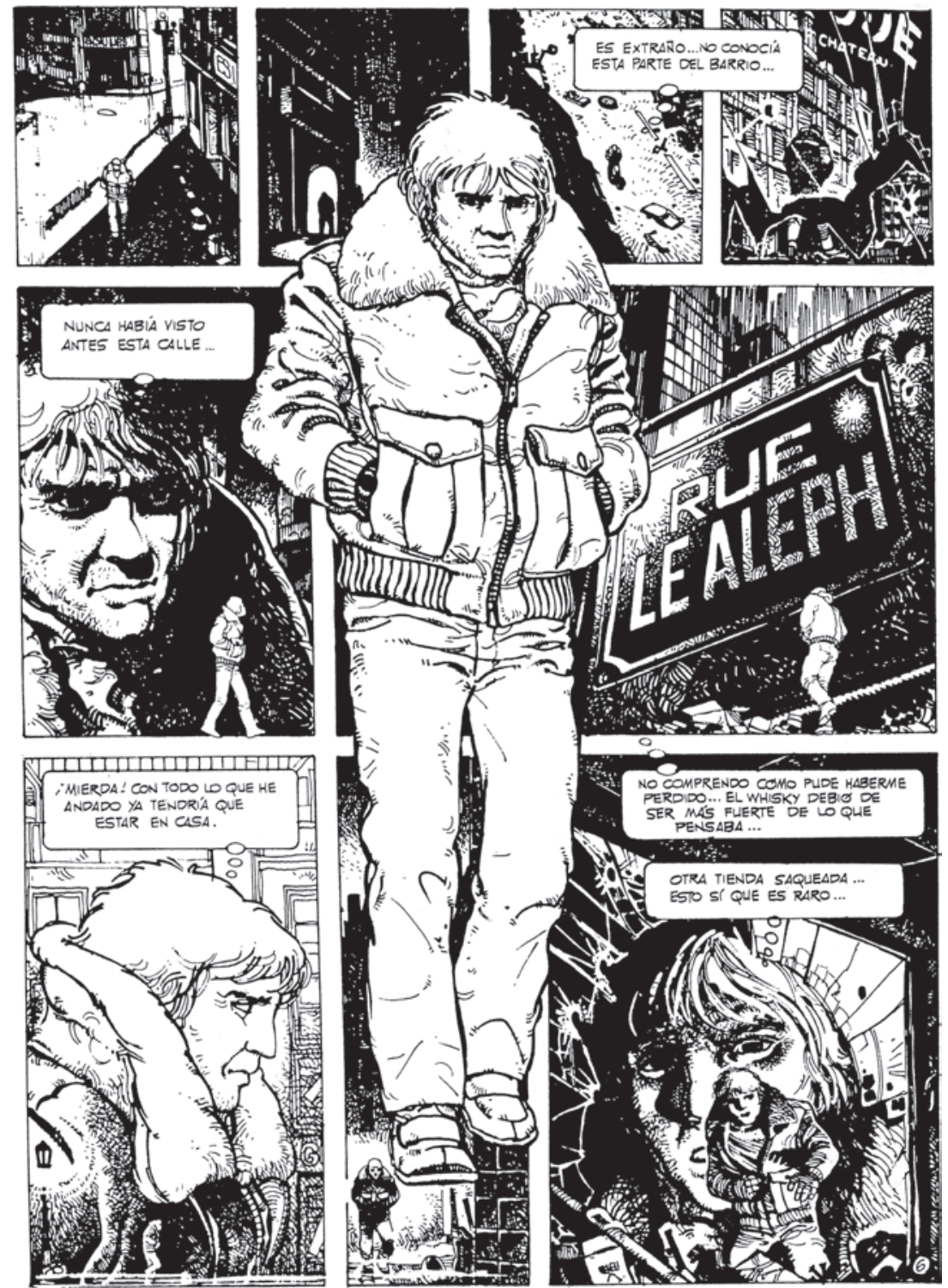

Fig. 6. Ciudad (Ricardo Barreiro and Juan Giménez, 1982), 5 
appears to represent a conglomerate of different cities from Europe and the Americas. Without warning, street signs change language from Spanish to French or English, and we slip imperceptibly between Paris and Buenos Aires with the same ease as Cortázar's protagonist in "El otro cielo" (Todos los fuegos el fuego, 1966). The city cannot be located in any specific time: some architectural designs seem to place us in the past and others in the future, while the people condemned to wander its streets also belong to different moments in history, stretching back to the eighteenth century. We are told that

la ciudad es un lugar fantástico. Quizá la intersección en un punto infinito de todos los continums [sic] espacio temporales de la tierra. . . . Aquí no existe lo imposible. No hay ni lógica ni reglas; estamos en el infierno y el paraíso, al mismo tiempo en el Aleph de Borges o la infundiblula $[$ sic $]$ cronosinclástica de Voneguth $[$ sic $] .{ }^{23}$

the city is a fantastical place. Perhaps the point of intersection in one infinite point of every space-time continuum on earth. . . . The impossible doesn't exist here. There is no logic and no rules; we're in heaven and hell, simultaneously in Borges's Aleph and Vonnegut's chrono-synclastic infundibulum.

The eponymous Aleph of Borges's short story (1945; also cited in fig. 6) is a point in space that contains all other points. In Kurt Vonnegut's novel The Sirens of Titan (1959), by entering a kind of wormhole, matter becomes scattered across time and space, existing simultaneously in different worlds and time zones. The "chrono-synclastic infundibulum" is a place where multiple truths coexist, fitting together although they would be logically incompatible in any single world.

From the I970s onward, literary quotation of this kind is extremely common in Argentine comics, which frequently cite Borges, Cortázar, or other writers of the fantastic tradition; a (more politically committed) version of Borges even becomes a character in Perramus (Juan Sasturain and Alberto Breccia, 1985-). Intertextual citation plays a key role in Ciudad's exploration of alternative temporal and spatial regimes, as the comic series establishes portals of its own between texts from different times and places. This technique is reinforced by the introduction into the story, toward the end of the first series, of Juan Salvo, the famed protagonist of El Eternauta, whose visage would be instantly recognizable to Argentine readers. As he recaps his story for them and describes his experiences traveling through parallel uni- 
verses, the panels and gutters that usually divide up time give way to three interior splash pages, presenting a collage of events from El Eternauta. While conveying the sense that all times are simultaneous to the time-traveling hero, these pages also demonstrate the effortlessness with which fictions may transgress the bounds of a book or comic panel to intermingle with other stories, creating a sense of a shared literary universe that both subtends and transcends the material one.

Ciudad's intertextual references thus do more than simply establish literary predecessors for its particular exploration of distortions in time and space: they also present the city as overlaid and underpinned by myths and legends, which have a determining force. The tales of Noah's Ark and the Pied Piper of Hamelin hijack an episode each, playing themselves out within the story-world of the comic. Vampires and sea monsters lend a historical density to the more modern threat of an automated hypermarket defended by punitive robots. The portrayal of the material city shot through with mythologies old and new echoes the vision of the city that emerges in Benjamin's writing, which aimed, as Gilloch suggests, to "unmask the modern metropolis as the site of the phantasmagoric and the mythic." 24 The material architecture of the city is interwoven with "the residues of a dream world," such as the arcades, exhibition halls, and panoramas of Benjamin's Paris, ${ }^{25}$ and becomes a space in which "the past constantly collides with the present and the real constantly merges with the mythological." ${ }^{26}$ This is a view of the city that is shared by García Canclini, for whom

Las ciudades se construyen con casas y parques, calles, autopistas y señales de tránsito. Pero las ciudades se configuran también con imágenes. Pueden ser las de los planos que las inventan y las ordenan. Pero también imaginan el sentido de la vida urbana las novelas, canciones y películas, los relatos de la prensa, la radio y televisión. La ciudad se vuelve densa al cargarse con fantasías heterogéneas. La urbe programada para funcionar, diseñada en cuadrícula, se desborda y se multiplica en ficciones individuales y colectivas. ${ }^{27}$

Cities are built with houses and parks, streets, motorways, and traffic lights. But cities are also shaped by images. These may be those of the plans that invent and order them. But the meaning of urban life is also imagined by novels, songs, and films, stories in the press, on radio and television. The city becomes dense under the weight of heterogeneous fantasies. The metropolis programmed to function, 
designed as a grid, bursts through and multiplies itself in individual and collective fictions.

The imaginary and the fantastic very much shape the fabric of the city in Ciudad: the buildings and parks the protagonists come across are often illusions or projections of some kind, and they soon learn that nothing in the city is what it seems: as we are told, "La ciudad es siempre la trampa, la apariencia engañosa, el doble juego" (the city is always the snare, the deceptive appearance, the double bluff). ${ }^{28}$

Might we then be tempted to situate Ciudad within the fantastic tradition in Argentine literature, given its emphasis on the city as constructed by texts and illusions? This reading would be complicated by the comic's commitment to bringing embodied practices to the fore and to pursuing a mimetic relationship with the irreducibly material dimensions of the city. The materiality of the city is continually emphasized in the characters' long journeys through an inhospitable environment, wearied by the discomfort of trudging along streets with the unbearable heat of the sun bouncing off the concrete. If the comic medium-with its temporal and spatial disjunctions and its frequent recourse to intertextual citation-may evoke the imaginary dimensions of the city with particular clarity, it may also accentuate its materiality. Ciudad's artwork repeatedly takes on the architectural forms of the city as the characters move through it. Narrow gauge, page-width horizontal panels mimic the shape of the metro tunnel as the train races between stations, and at one point the sketch of a train stands in for one strip, with its open doors imitating the shape of a panel (fig. 7). The steep-angled verticals of the cathedral are echoed in other panels on the same page, which trace lines of similar weight and slant, integrating the cathedral's lineaments into the broader visual design of the comic itself. ${ }^{29}$

In other ways, too, Ciudad points to the physical fabric and the material conditions of the Latin American city, which continually seep through the comic's fantastical images and tales. The comic's depiction of the city faithfully reflects the changes experienced in Latin American cities in the latter half of the twentieth century, which became increasingly polycentric as new urbanizations sprang up around huge out-of-town shopping malls and the middle classes moved out in search of safer, greener suburbs. As García Canclini explains, we now find ourselves in "una ciudad diseminada, una ciudad de la que cada vez tenemos menos idea dónde termina, dónde empieza, en qué lugar estamos" (a dispersed city, a city about which we have less and less idea where it ends, where it begins, and where we are within it). ${ }^{30}$ Ciudad is 


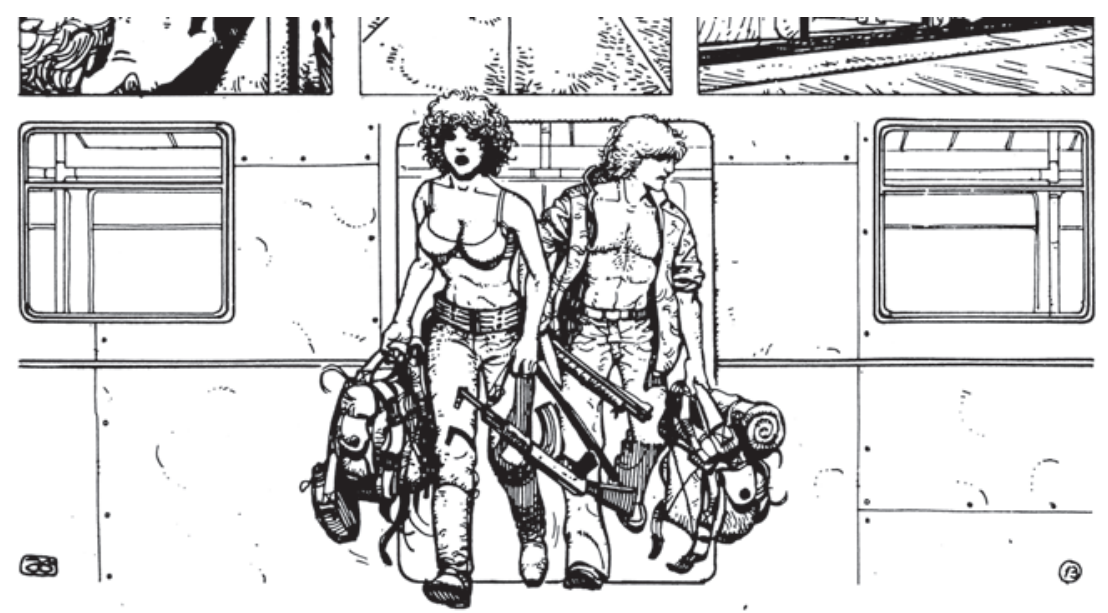

Fig. 7. Ciudad (Ricardo Barreiro and Juan Giménez, 1982), 66

remarkably prescient of these changes, which would gather pace in the years following its first publication. One of the most remarkable features of the city it depicts is the utter lack of integration of its different spaces. Any civic center or seat of government is noticeably absent, and the city is carved up instead into segregated barrios differentiated by their relative state of social and economic development.

Other features of the city in Ciudad also map out the particular configurations of urban space in late twentieth-century Latin America. The vast and futuristic "Auto Supermarket" that provides the setting for the third episode calls to mind the Americanized shopping malls that would multiply in and around large Latin American cities during the late 1980s and 1990s, following the first North American-style commercial centers that appeared in Brazil and Mexico toward the end of the I970s. The self-defended neighborhood of the "Barrio Castillo" episode strongly evokes the privatization of urban space and security in the barrios privados (gated communities) that were to become extremely popular among the middle classes in Buenos Aires and other capitals from the I990s onward.

If it is the disciplinary function of the city-state in Ministerio that endangers the lives of its characters, it is the absence of governance that is often the greatest threat to the protagonists of Ciudad. The city becomes both the site of terrifying power, exercised though technologies of surveillance and con- 
trol, and a lawless jungle of uncontrolled violence and barbarism. Drawing on Lewis Mumford and Theodore Rozniak, Gary K. Wolfe finds that the modern city, especially as represented in science fiction, is

an unmanageable, cacophonous, barely conceivable environment that has long since shifted from the communal imperative to the survival imperative: cities that were once social organizations to promote the protection of the individual from a hostile and chaotic environment must now devote more and more of their resources to the protection of the individual from the hostile and chaotic environment that the city itself has become. ${ }^{31}$

This observation is particularly apt with respect to the Latin American city, in which the original rationalist plan, marked out on a grid, has overflowed into informal, unregulated, unpredictable spaces, which often exist in a state of lawlessness or are effectively governed by forces beyond state control. Against this backdrop, however, plays the phantasm of large-scale state repression of the kind experienced in the Southern Cone dictatorships during the 1970s and 1980s. In a similar manner, the city in Barreiro's comics is a space that is always characterized by too much or too little centralized power and order.

The notion of the city as the intersection of space-time continuums is of course one drawn from science fiction, but it is perhaps not so far removed from the disorienting jumble of conflicting temporalities that make up the Latin American cityscape, and that often provoke what García Canclini describes as "esta sensación de vivir a la vez en varios siglos" (the sensation of living in different centuries at the same time) ${ }^{32}$ In a way that is particularly marked in the Latin American megalopolis, the archaic remains visible within the cracks of an uneven modernization. Traditional forms of social organization and cultural practices are juxtaposed with high-tech communications that connect elite sectors of the city to a high-speed, globalized, postmodern world. As García Canclini suggests,

Vivimos la tensión entre tradiciones que todavía no se van (tradiciones barriales, de formas de organización y estilos de comunicación urbana) y una modernidad que no acaba de llegar a los países latinoamericanos, cuya precariedad no impide, sin embargo, que también lo posmoderno ya esté entre nosotros. ${ }^{33}$ 
We live at a point of tension between traditions that have not yet disappeared (local customs and forms of organization and urban communication) and a modernity that has not fully arrived in Latin American countries, the frailty of which does not, however, impede the postmodern from taking its place among us.

In this context, Ciudad's fantastical conjunction of ultramodern edifices with decaying neighborhoods trapped in the past effectively recalls the inequalities that were to shape the use of urban space in Latin American cities during the latter decades of the twentieth century. This is one of many ways in which the comic's apparently fantastical treatment of time and space may be understood to be firmly rooted within the specific and material realities of urban experience in Latin America.

Social inequality and the weakness of the state also become central themes in a later series, Cain. Barreiro constructs a vision of a deeply divided Buenos Aires in which the rich neighborhoods "vampirize" the poverty-ridden periphery, ${ }^{34}$ while the state, big business, and the media are caught up in webs of corruption and crime. Like Ciudad, Cain showed uncanny clairvoyance in respect of the profound impact of neoliberal policies that would transform the cityscape of Buenos Aires during the 1990s, as multinational companies charged into the capital.

In his essay "One-Way Street," written in 1928, Benjamin describes a significant change in the place of writing in the modern city. Having previously enjoyed an independent existence in the printed book, writing has become an integral part of the cityscape, "ruthlessly dragged out into the street by advertisements and subjected to the brutal heteronomies of economic chaos." ${ }^{35}$ From the stillness of reading a book, we are now exposed to different kinds of reading, "a flurry of changeable, brightly coloured, clashing characters" and "locust swarms of lettering" that rise vertically, drawing our eyes upward to the neon signs and advertising billboards of the city. ${ }^{36}$ It has been pointed out, by Balzer among others, that the comic evokes this modern use of writing in the city with admirable precision, with its insertion of texts within images and its exploitation of vertical as well as horizontal planes of reading. ${ }^{37}$

Cain illustrates with great clarity this penetration of writing into the cityscape in the form of advertising and the "locust swarms" of neon lights. However, the texts woven into this city's fabric tell a specific story, of the power of multinational business and the weakness of the state: the "brutal heteronomies of economic chaos" of Benjamin's phrase, perhaps, which ges- 


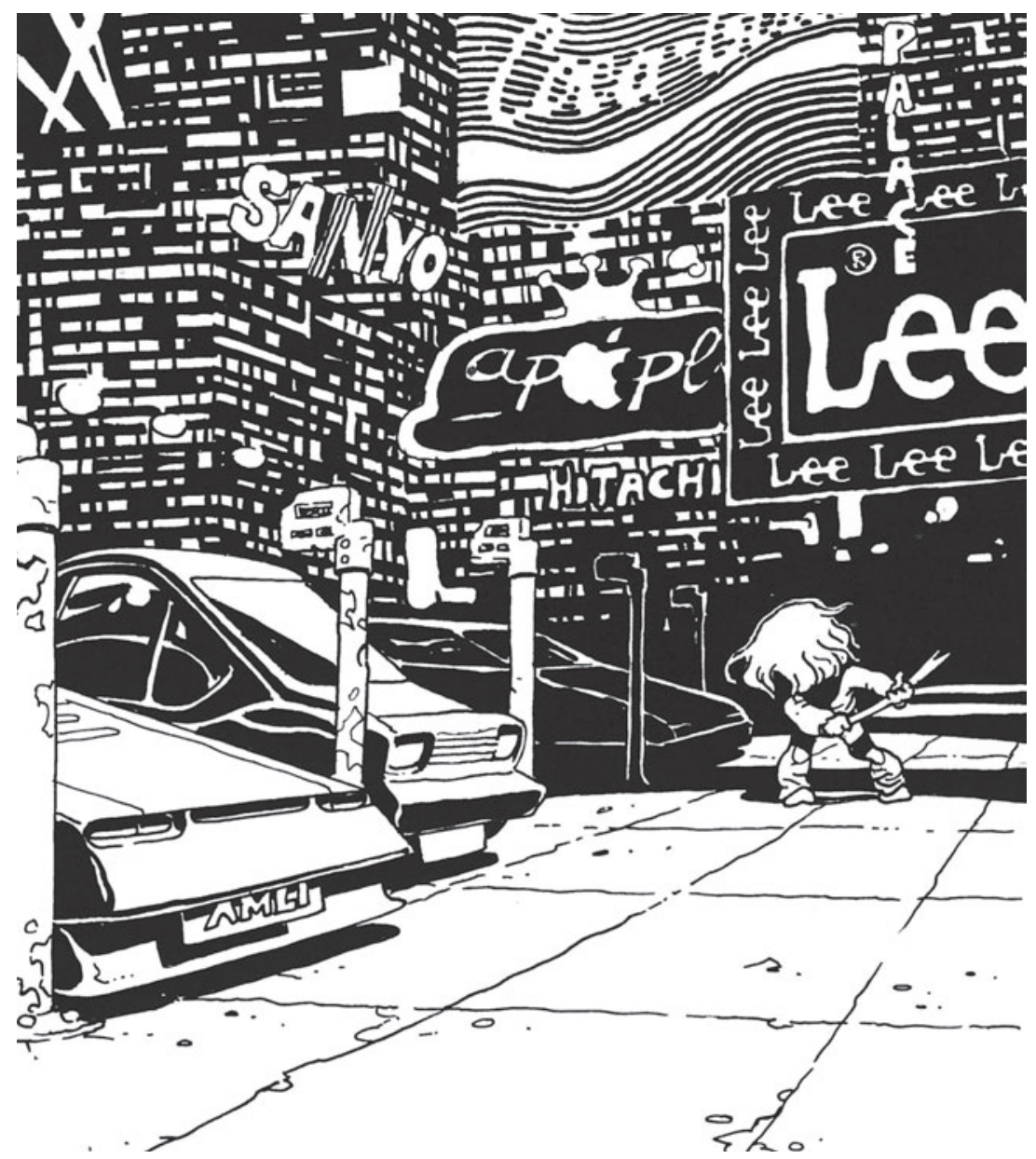

Fig. 8. Cain (Ricardo Barreiro and Eduardo Risso, 1988), 9 (detail)

tures toward the state's subjection to external forces. The oversized, neon-lit words in Cain (fig. 8) are rendered in stark black and white, plastered across tower blocks whose tiny illuminated windows, forming horizontal rectangles of differing length against a black background, also take on the appearance of block type seen from afar. We are urged to read the cityscape, both literally and metaphorically: the signs all refer to well-known global brands rather than Argentine ones, brands that flooded the market in Argentina under the neoliberal regime of the I990s and often drove local companies out of business. In Cain, multinationals are also suspiciously involved in 
the state's discipline of its citizens. A sign forbidding entry to a juvenile reform institution carries the surprising strap line: "Auspicia esta norma legal Siemens" (This regulation is sponsored by Siemens)..$^{38}$ Caín, the hero of the comic, is left for dead after the brutal police repression of a riot at the reformatory, and sold in a vegetative state to a medical company experimenting with prosthetic brains. We are told that the Ronald Reagan Medical Foundation is just one of many multinational corporations that, because of the lack of control exercised by the Argentine state, is able to carry out experiments on human guinea pigs that would be banned anywhere else in the world.

One of the comic's grandest signs (fig. 9) encodes a biting critique of the relationship between the state and big business in Argentina. Caín's evil stepbrother has robbed him of his inheritance, ownership of his father's huge company. Its headquarters fill the panel here, with the company's imposing status and influence clearly magnified by the use of a low-angle perspective. Throughout Cain, hard angles and geometric shapes are associated with city-center spaces and sites of power, while more softly traced, sinuous, and untidy lines are, by contrast, reserved for the impoverished ruins of the city's periphery, Caín's home. The company's name emblazoned on the tower, "Bunge De Hoz," is a combination of two names with a particular resonance for Argentine readers. "Bunge" refers to Bunge and Born, a giant agricultural conglomerate started by European immigrants to Argentina in the late nineteenth century, while "De Hoz" represents José Alfredo Martínez de Hoz, who was minister of the economy during the $1976-83$ dictatorship. He was responsible for setting in train a dramatic reshaping of the nation's economy through his pursuit of neoliberal policies. While these brought some initial success in fighting inflation, they ultimately benefited the four or five largest and most powerful companies in Argentina, including Bunge and Born, at the expense of smaller, local businesses. These companies were given special access to the government and enjoyed a series of privileges, including the ability to fix prices, while smaller companies were given little or no protection, and many went bankrupt. ${ }^{39}$

Unlike Ciudad, Cain does not often indulge in overt intertextual play; ${ }^{40}$ however, it does introduce a form of reflexivity in its adoption of the modes of perception of a range of different visual technologies and its experimentation with unusual "camera" angles. Cinematographic zooms take us closer to the action, while at other points our vision is directed through binocular lenses or Caín's infra-red, target-seeking prosthetic eye. Unexpected "shots" from behind a televisual image or beneath a parrilla (a metal-wired bed used in electric shock torture) insistently draw our attention to the unusual use of 


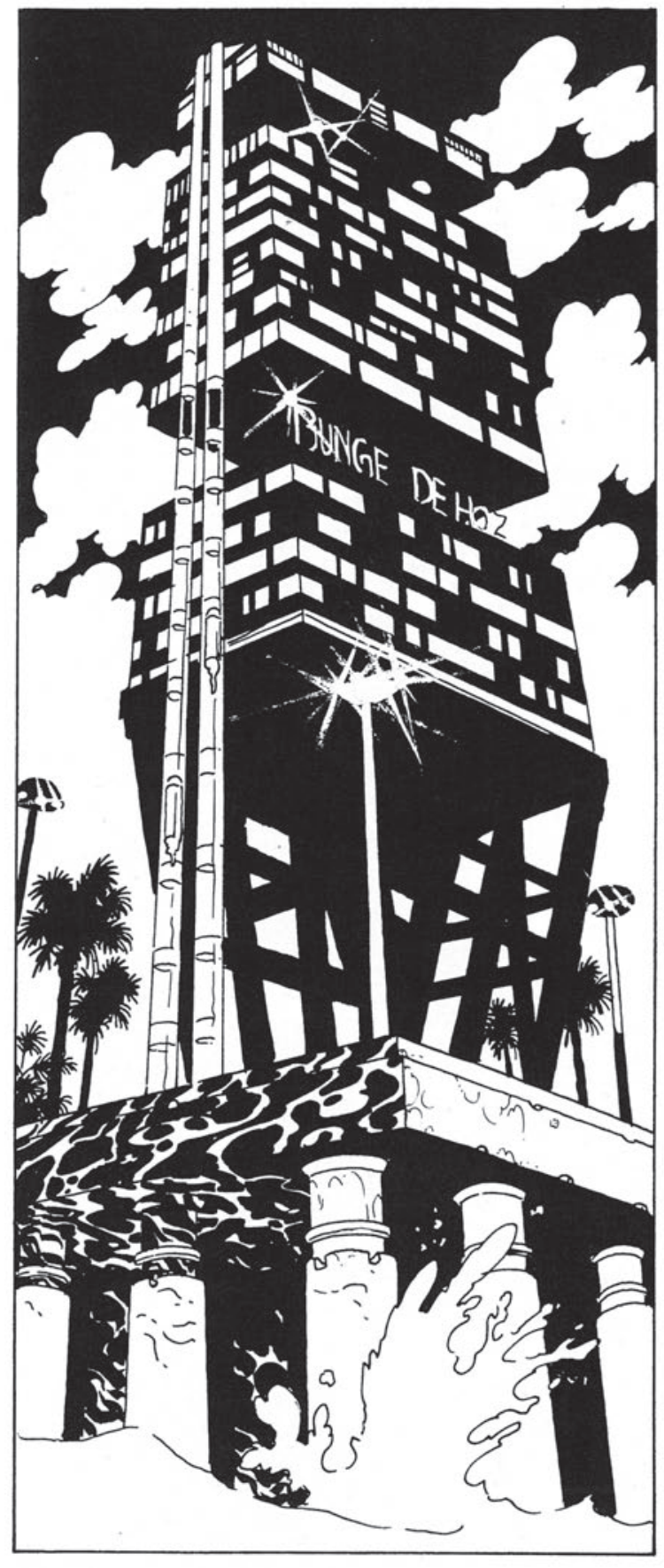

Fig. 9. Cain (Ricardo Barreiro and Eduardo Risso, I988), 57 
perspective in panel composition. The comic's square, grid-like arrangement of panels receives repeated visual echoes within the frames, in the tiled backgrounds of a great number of scenes, in a checked blazer, brick walls, the square geometry of fitted kitchen cupboards, the glass panels of an atrium roof, and the multiple screens of a television studio. Often set at a violent angle, the checked patterns and grids within the panels immerse us in austere and alarming cage-like structures. This is a city made in the image of a comic, an effect heightened by Risso's use of stark solid blacks and an unflinching, cutout style to emphasize two-dimensionality.

If Ciudad's panels were molded to take on the forms of the city's architecture, then, Cain reverses the relationship, actively constructing the city with the forms and dimensions of a comic. Both series, however, play on formal analogies between the comic medium and the city, and position themselves in a clear mimetic relationship with a broader materiality that embraces a world beyond the comic's pages. Risso's nonnaturalistic, hard angles and flat surfaces in Cain enhance the brutality of the cityscape and throw into relief the softer curves of human features. Illustrated in a contrasting style, Giménez's Ciudad also evokes a sense of materiality through highly textured facades and shadows filled with dense and irregular crosshatching. This draws particular attention to the material tools of the comic's production and the physical activity of drawing. This emphasis is entirely consonant with the rise of the auteur comic during the I980s. It also suggests ways in which graphic fiction does not simply establish a mimetic relationship with the material world but may even be understood, as a product crafted from ink and paper, to participate in that materiality. The unique combination of text and image in graphic fiction allows for a complex form of mediation that does not translate the city's physical dimensions into a dematerialized form of discourse. Instead, it closely reproduces the forms and textures of urban space and insists on its own reliance on textual practices that are embodied and material in nature.

\section{Comics, the Archive, and Cognitive Practices}

Gardner notes an "archival turn" in contemporary graphic fiction, finding the superheroes of yore to have been replaced by "tales of collectors, the compulsive combers of archives, warehouses, and dumpsters." ${ }^{41}$ The comic is "closer to the archive than to traditional narrative forms," he claims: "Like the archive, the comics form retains that which cannot be reconciled to 
linear narrative." ${ }^{\not 2}$ It is this excess of signs, texts, and images, continually threatening to dissolve the ordered frames of a neat, linear narrative, that often makes the comic form so suited to representing the complexity of urban experience. Both Gardner and Enns draw on the highly suggestive figure of the archive developed in Benjamin's writing, as a conglomeration of texts and images in which the ruins of the past are interwoven with dreams of the yet-to-come. They propose that the comic medium is ideally suited to the task of 'making the present aware of its own 'archive,' the past that it is always in the process of becoming," 43 particularly given its use of montage, the form preferred by Benjamin for its capacity to bring images of the past and present into a dialectical relationship. ${ }^{44}$

This line of investigation opens up very fruitful ways of understanding the self-representation of comics as a space for collecting and reflecting on heterogeneous fragments of the everyday, altering our perception of the relationship between past and present very much in the way that Benjamin envisaged. While the figure of the comic-as-archive may illuminate a great deal about reflexivity in graphic fiction, however, it may also conceal the more active role of comics in transforming and translating its texts and images, and in giving material form to the invisible and the intangible. While the arrangement and classification of artifacts within an archive always suggest new constellations of meaning, the comic's use of existing material involves a far more active reappropriation. This is particularly the case in science fiction comics, given the overlaying of additional meanings that results from the genre's typically parodic mode, particularly in Argentina.

In the discussion that follows of an earlier comic series scripted by Barreiro, Slot-Barr (with Solano López, 1976) ${ }^{45}$ I will suggest that the "archival drive" that Gardner equates with comic form and production ${ }^{46}$ may be understood as part of a much larger toolbox of cognitive practices. Additional figures such as the map, the encyclopedia, and the compendium allow us to gain a fuller sense of graphic fiction's reflexive self-positioning. These figures are placed under erasure within comic discourse and form, often subjected to parody but nevertheless revealing an underlying didactic aspiration to orientate readers within an ever more complex environment, as well as a desire to create a way for comics to take their place in the "archive," that space of cultural legitimation, alongside other forms of literary and visual media. Again, this ambition may be read within the context of the nascent development of the auteur comic, both in Argentina and beyond.

Gardner and Enns produce cogent readings of the comics they present as examples of the comic-as-archive (the work of Ben Katchor and Kim Deitch 
in the case of the former, and Jason Lutes's Berlin in the latter), detailing ways in which they respond to a desire to capture "the forgotten traces of the past." ${ }^{37}$ However, this kind of chronicling is rarely in evidence in science fiction comics. While these may, indeed, construct futuristic worlds in order to address historical themes or contemporary concerns, they do not respond in any straightforward manner to the kind of archival impulse that Pierre Nora brands the "imperative of our epoch"; ${ }^{48}$ nor do they usually participate in the rise of memory discourses and musealization that, for Andreas Huyssen, "together are called upon to provide a bulwark against obsolescence and disappearance, to counter our deep anxiety about the speed of change and the ever-shrinking horizons of time and space." ${ }^{29}$ Science fiction comics more typically celebrate the universality and mutability of myth in a way that is deliberately dehistoricizing, and the frequent use of pseudoscience and imaginary science parodies the pursuit of knowledge and the preservation of the past.

Barreiro's comics often pay ironic homage to the dual function of entertainment and education in the tradition of science fiction comics. These have often taken the opportunity to introduce readers to relevant scientific discoveries or facts-such as the principles of nuclear physics or the rudiments of space rocket design —or to frame social messages about the impact of scientific advance within their narratives, in the manner of the ecologically orientated stories of the I970s U.S. magazine Slow Death. Closer to home, Raúl Roux's Más allá (1938) peppered its narrative with explanations of planetary orbits and Newton's law of gravity. In an ironic replay of this relationship between entertainment and knowledge, the action of Ministerio is unsubtly interrupted by asides addressed to the reader, giving spurious information about the precise biological makeup of the particular (fictional) species currently attacking the protagonist. The example in figure Io lays out classic longitudinal and cross-section presentations of a mutant spider, the giant polyphagous multipede. The use of labels and arrows mimics the meticulous diagrams of a zoology textbook, while the continuing narration-which, as it is confined to a box matching the other labels, appears to adopt the authoritative voice of science-hybridizes the language of scientific description with that of the horror genre in its reference to the "gigantesco" (gigantic) specimen of a species known to be "devoradores insaciables" (insatiable devourers). At another point, an editorial interjection cuts into the narrative at a moment of maximum suspense, leaving the protagonist literally dangling from an elevator cable, in order to appeal to us as readers to forgive a forthcoming digression in the name of the advancement 


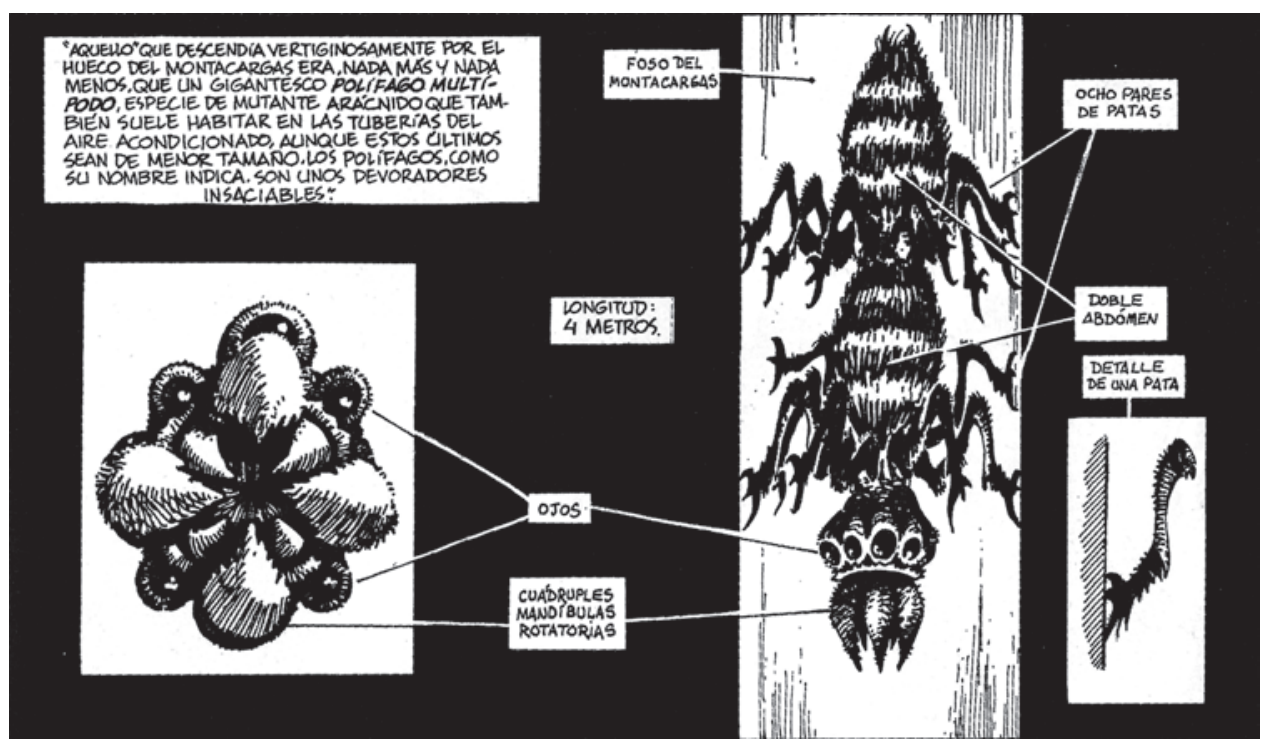

Fig. Io. Ministerio (Ricardo Barreiro and Francisco Solano López, I986), 39

of knowledge. A page of background information ensues on the "Ese Ese," the protagonist's android pursuers, before we rejoin our hero, still clinging valiantly to the cable.

In other works by Barreiro, the archive becomes an object of critique, fully imbricated with acts of ideological manipulation and the abuse of power. The science fiction genre is characteristically suspicious of the relationship between colonial power and knowledge, a collusion that takes on a particular resonance in the Latin American context. This suspicion of the archive is a central theme in Barreiro's I970s series, Slot-Barr. Slot's heroic, galaxy-tripping adventures are prefaced and punctuated by texts of an overtly didactic nature, including a chronology and a historical report, attributed to a historian who appears later as a character in the narrative. The report advances a dependency-theory explanation for the economic inequalities of the future (which, naturally, bear a marked resemblance to those of the present). Later, interspersed fragments from the fictional Enciclopedia galáctica abreviada give "scientific" accounts of the technical operations of different spacecraft and the anatomy of predatory space creatures (fig. II).

Barreiro's Enciclopedia galáctica is a reference to the fictional Encyclopaedia Galactica of the future civilization created in Isaac Asimov's Foundation trilogy (195I-53). Written in the neutral tone proper to the genre, the oc- 


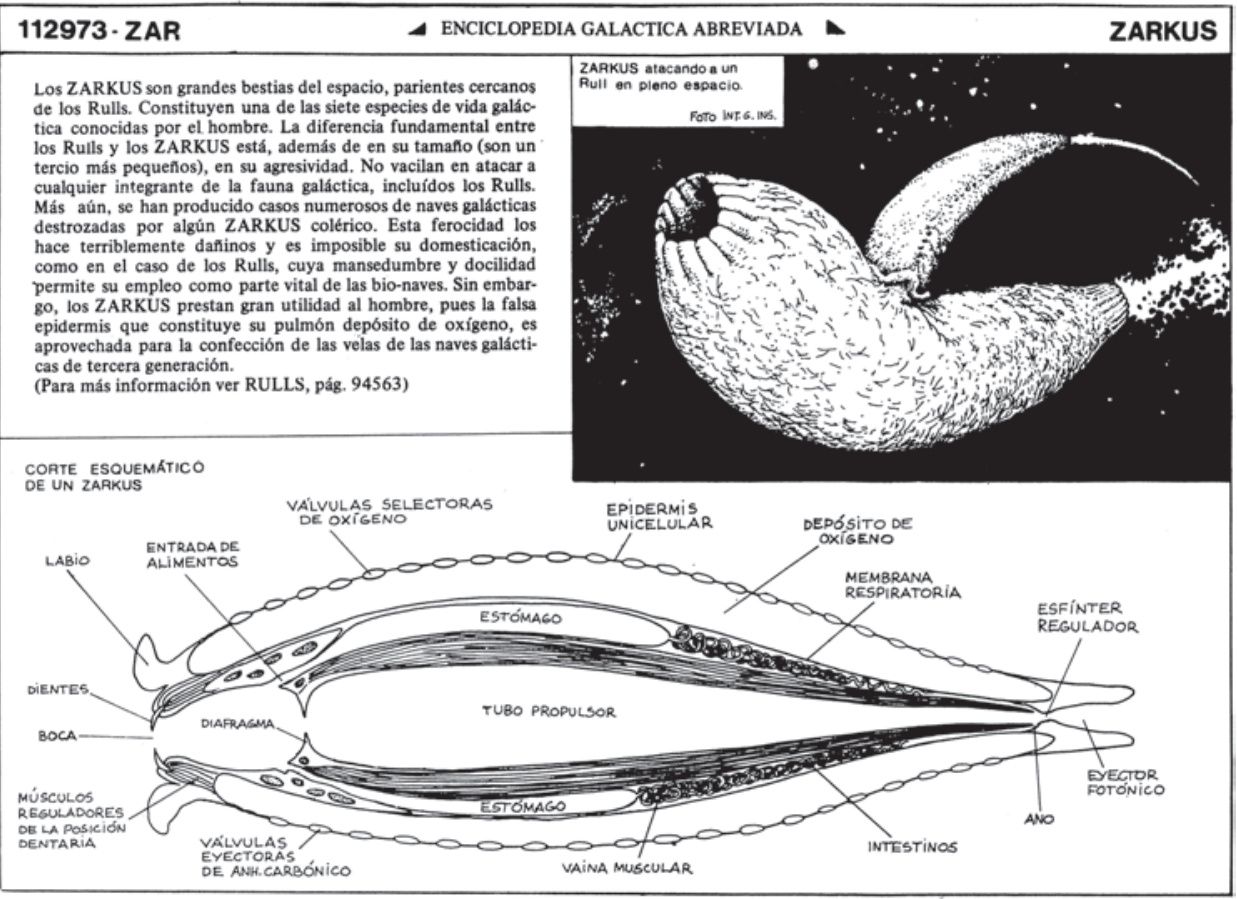

Fig. II. Slot-Barr (Ricardo Barreiro and Solano López, 1976), I68

casional excerpts Asimov places at the beginning of his chapters lend a sense of historical depth and verisimilitude to his invented universe. We later discover, however, the extent to which the Encyclopaedia's data-gathering and data-preserving project is fundamental to a bid for power on the part of its compilers. A similarly sinister intent governs the promotion of the Enciclopedia galáctica in Slot-Barr. At first sight, the insertion of encyclopedia entries adds gravity and scientific credibility to the comic's fantastical inventions. Building on Asimov's technique, Barreiro and Solano López exploit the comic's capacity for visual collage, composing mocked-up pages of short entries and explanatory diagrams, rendered in scholastic small type. The addition of spurious entry numbers and cross-references (see fig. II) create the illusion of a totalizing work of monumental proportions, while the level of detail employed, completely unnecessary to the development of the plot, points to SF's commitment to worldbuilding. However, it becomes clear in Slot-Barr that the encyclopedia is also a tool of mystification, used by the ruling Confederation to propagate a lie, to hide the true origins of humanity 
and position itself at the center of human history. The encyclopedia is "otra de sus tantas falsedades" (one of its many falsehoods) ${ }^{50}$ wielded in the name of power.

Indeed, the recourse to archives throughout Slot-Barr yields only deception and decayed remnants. In the sixth episode, Slot travels to Earth to search for a book that contains the secret prehistory of humanity and the origins of the Confederación Empire. It is this book, "el libro de los libros" (the book of books), that contains the key to liberating the citizens of the beleaguered planet Guewar 2 from the imperial forces of the Confederation. ${ }^{51} \mathrm{~A}$ knowledge of the origins of humanity and how the Confederation was able to establish its power is crucial to the success of the revolutionaries. Sadly, Slot discovers that time has taken its toll on the book, and only a fragment remains legible. It reads: "La historia del hombre no es sino la de la lucha entre el débil y el poderoso, entre el pobre y el rico" (The history of humankind is nothing but the battle between the weak and the powerful, between the poor and the rich). ${ }^{52}$ Although he and his fellow travelers are cast into gloom at the demise of the book, which cannot now ensure the salvation of the plucky rebels of Guewar 2, in Slot-Barr's historical-materialist vision this scrap of text is of course the true key to liberation, bringing a proper understanding of the role of class war in the evolution of human history. Unlike the "book of books" in Borges's fictions, which lies forever out of our grasp ("La biblioteca de Babel") or leads us only into a textual labyrinth from which there is no escape ("El jardín de senderos que se bifurcan"), Barreiro's "book of books" bears clear witness to the material conditions of existence that shape life beyond the text.

Borges's stories are canonical examples of the fantastic tradition in River Plate literature, in which texts invariably lead us only to other texts, and what we see around us is revealed to be a complex illusion created by and embedded in acts of language and of the imagination. Self-reference in Barreiro's graphic fiction and the comic medium more generally, I suggest, is rarely of this kind: it does not destroy the mimetic relationship between text and world but often enhances it, countering the antimaterialist, narcissistic thrust of postmodern reflexivity. Ole Frahm reminds us of a common reflexive device in comics, in which a character is presented to us as reading the same pages of the comic in which he is depicted. For Frahm, this destroys the illusion that the comic refers to an external world and effectively parodies "the very notion of an original." As a classic example, he cites Al Williamson's "The Aliens" (1953), in which the aliens come across a copy of the same comic that we are reading ourselves. The story becomes so self- 
referential that by the end, it refers only to itself, referring to itself, referring to itself ad infinitum (fig. I2). A similar panel is included toward the end of Ciudad, when Juan Salvo conjectures that they may all be characters in a novel, a film, or even a comic (fig. 13). However, both of these examples are arguably much less hermetic than Frahm would suggest. While "The Aliens" ends with a dizzying mise en abyme, it is one that insists on the material dimensions of the comic. The final caption returns us to the physical copy we are holding, reminding us that it will have a role to play in the future events narrated in the comic: "This may be the very magazine those creatures will find when they land on the exploded fragment of earth!" In a similar way, the mise en abyme panel in Ciudad, which duplicates our own hands holding the comic, leaves us acutely aware of reading, not just as a mental activity but also as one that involves the visual and tactile senses and the physical act of holding a magazine or book and turning its pages. Ciudad does not, moreover, end with this image, but with Juan Salvo's decision to take the only possible route out of the city, even if it may be a trap. Indeed, reflexivity in Barreiro's comics often leads outward rather than inward, directing the reader to the real world beyond the comic.

Ministerio also ends with a reflexive reframing of its own story, but one that points us beyond its pages to its political context. We discover that the comic we are reading has been written by the main character: as we turn the last page, we see him writing "THE END" on the panel we have just seen at the foot of the previous page (fig. I4). In that panel, his joy at the liberation from the evil regime is subdued as he recollects his two friends who lost their lives in the struggle. The comic continues for another page, relating his excitement at finishing the comic we have been reading. But this too is tempered by the sobering sight of police violence on the street outside. The final panel of the book we read, in which the protagonist repeats the names of the absent friends of the comic-book story as he witnesses civilians being thrown into the back of a van at gunpoint, establishes a clear link between the apocalyptic terrors of the fictional regime of Ministerio and the brutal abuses of state power in Argentina.

In contrast to the kind of self-reference Frahm theorizes, reflexivity here does not parody "the recurrent notion that, in some cases, a proximity between object and sign actually exists that can be called truth." ${ }^{53}$ It does the opposite: it insists on its relevance to what is taking place beyond the comic and constructs the comic as a form of truth telling. It is not a textual labyrinth in which we are trapped, but a much broader and stickier web of violence and impunity. Barreiro and Solano López make use of the mate- 


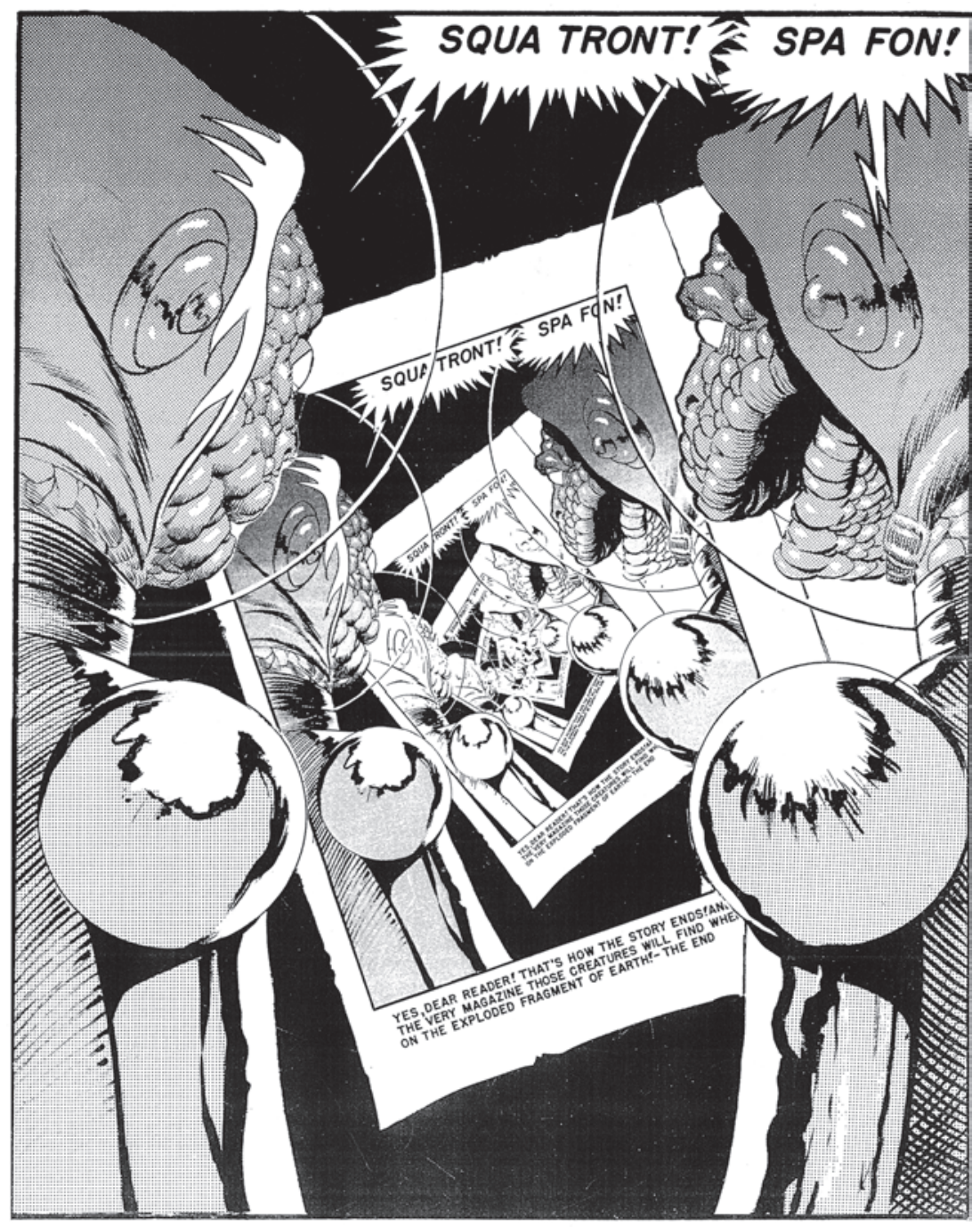

YES, DEAR READER! THAT'S HOW THE STORY ENDS!AND THIS MAY BE THE VERY MAGAZINE THOSE GREATURES WILL FIND WHEN THEY LAND ON THE EXPLODED FRAGMENT OF EARTH?- THE END

Fig. I2. "The Aliens" (Al Williamson), Weird Fantasy I. no. I7 (January-February 1953) 


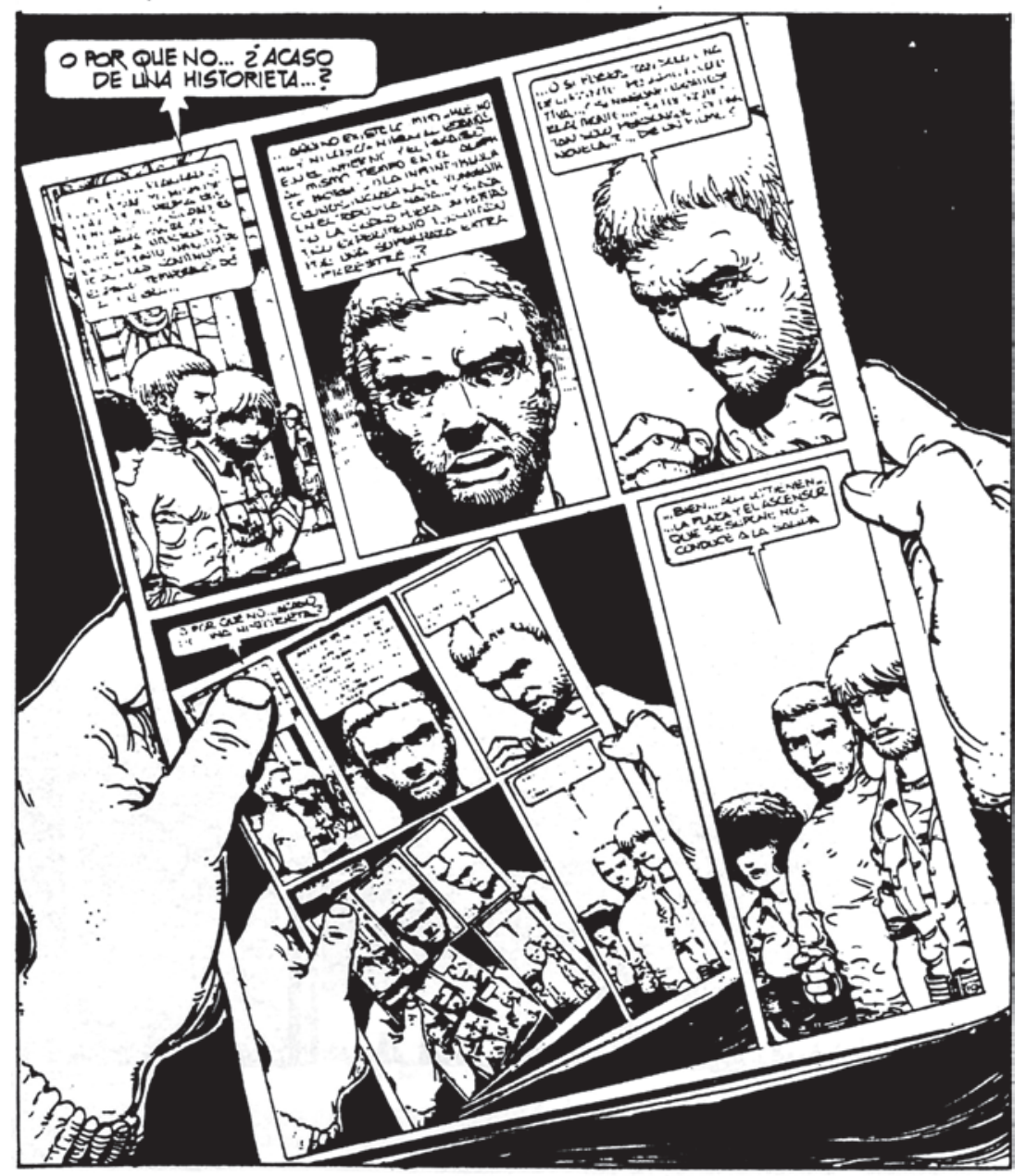

Fig. 13. Ciudad (Ricardo Barreiro and Juan Giménez, I982), I59

rial form of the comic — the "mise en page" - to render the physical act of page-turning significant to the narrative and to highlight the insertion of the comic's pages within the social and political realities of its context.

The montage form of the comic, together with its use of heterogeneous texts and images to capture the complex relationship between memory and reality, suggests an affinity with the archive as Benjamin both imagined it and created it: as a space in which new meanings may arise from shuffling or reordering of texts and visual documents. However, while the archive is 


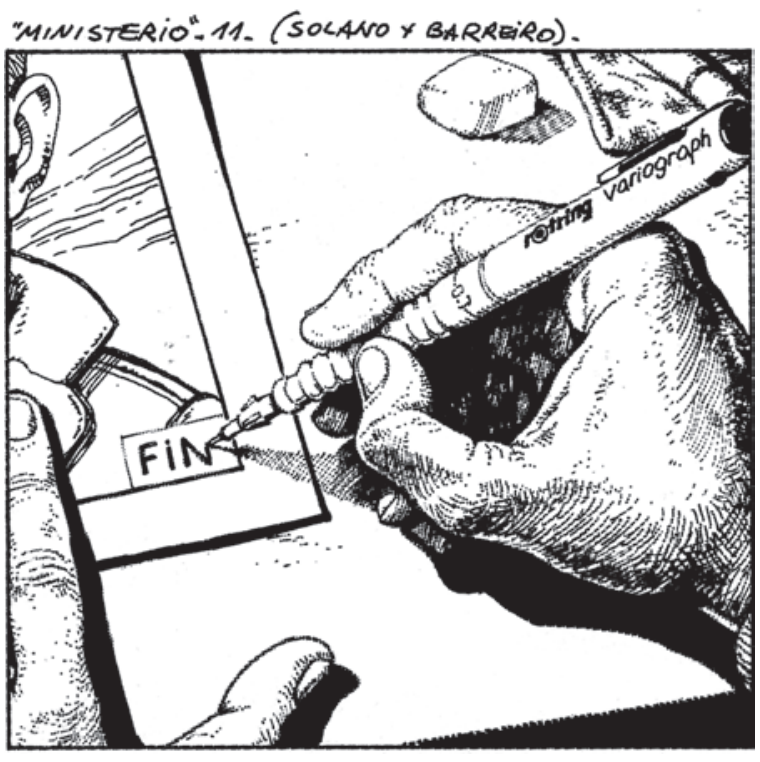

Fig. I4. Ministerio

(Ricardo Barreiro and Francisco Solano López, 1986), 96

always in need of an archivist to create meanings by ordering and classifying the material gathered in it, science fiction comics often take a much more active role in providing an aid to exploration, styling themselves as a map or a manual to orientate readers in their created worlds. It is in the nature of science fiction, of course, that such maps relate as much to the present world as any future one. While Slot-Barr's didactic impulse appears to be directed toward alien forms (here's how to recognize a Zarkus if you are unlucky enough to come across one in outer space), it really aims to persuade its readers to adopt a historical-materialist view of economic inequality (here's how to demystify imperial discourses of power and fight for liberation). It is here that a tension emerges between the parodic mode of many science fiction comics and the desire to retain an instructive role for the comic itself in training its readers to "read" political and social realities, in a manner more reminiscent of earlier revolutionary comics such as those scripted by Oesterheld.

Rather than the montage work associated with the archive, it may be more relevant to think of the comic's operations in terms of the digest. The well-known Classics Illustrated, which began in 194I, was responsible for abridging and illustrating nearly 170 works of world literature in comic form. ${ }^{54}$ However, the technique of literary adaptation is to be found everywhere in comics, and particularly in science fiction. Barreiro's Slot is a 
composite figure, taking on the travels and the travails of his literary forebears. Barreiro dedicates an entire chapter to the retelling of a version of Herman Melville's Moby Dick (I85I), with Slot adopting the role of Ishmael; other characters whose stories overlap with Slot's are Homer's Ulysses and Hugo Pratt's cult hero El Corto Maltés (Corto Maltese), created in 1967 and the protagonist of multiple comics series. What links Slot-Barr's intertextual citations is the motif of a journey across the seas, and these three literary sailors-Ishmael, Ulysses, El Corto Maltés—are united and updated in Slot, who cruises in a similar way across the galaxies in his "nave-vela" (sail-ship), a spacecraft boasting a giant parabolic membrane that allows travel near the speed of light.

The comic becomes a site for the embedding, articulation, and revision of literary classics, both ancient and modern, and—crucially—a space in which high culture may meet popular culture on mutual ground. The figure of the archive takes insufficient account of the active transformations and transmediations to which comics subject their material. The acts of collecting and ordering, however meaningful the resulting constellations of texts and images may be, do not fully describe the work commonly undertaken by comics of translating or abridging texts, or restyling images for different markets. Direct citations are rare: everything is revoiced, retold, redrawn, rewritten. This is emphasized within the text of Slot-Barr itself, as the narrative is continually taken up by new voices or told from the perspective of different world histories. Unlike an archive, this is not a work of salvage but of plunder; not an exercise in preservation but one of conscious adaptation and transformation.

The comic becomes in this way a compendium of world literature in its historical and geographical sweep. An encyclopedic reach is common to much of Barreiro's graphic fiction, in which writers and characters of the Western literary canon also appear alongside more contemporary, local, and popular figures. In the first series of Parque Chas (Barreiro and Risso, 1987), ${ }^{55}$ Melville, El Corto Maltés, and El Eternauta are joined by Giuseppe Bergman, a character created in 1978 by the Italian graphic novelist Milo Manara, and Alejandro Ricardo Dolina, an Argentine broadcaster and popular writer of the time, with other representatives of the nation including Diego Maradona and Borges. Barreiro consciously popularizes the canon and celebrates the comic's versatility in assembling and transforming images and texts of all kinds. Such acts also point to graphic fiction's uneasy relationship to that canon, particularly prior to the auteur movement in comics, which gathered force in the 1980 as as the graphic novel found greater acceptance within elite 
culture. If Slot-Barr and Ciudad present themselves more as paraliterature than literature, however, they do so in order to claim a particular role for the comic in incorporating, adapting, and popularizing a vast breadth of other texts and perspectives.

\section{Conclusion: (Re)materialization in Graphic Fiction}

The figure of the Benjaminian archive therefore illuminates but does not fully account for the work of comics, drawing useful attention to the particular ease with which the comic brings together the material and the mythological but understating the extent to which the comic - in science fiction, especially_styles itself as a didactic tool and a digest of world culture, while simultaneously subjecting such pedagogical pretensions to parody. Importantly, it does not encourage us to consider the materializing operations of graphic fiction, which does not simply gather together existing remnants but purposefully translates sounds into printed letters, and time and movement into spatial forms. As Lucas Berone suggests, "La historieta provoca así una cierta materialización de lo incorpóreo, la caída en la materia de lo que había permanecido ajeno a las cosas: el lenguaje" (In this way, the comic brings about a certain materialization of the intangible, the lapse into material substance of what had remained aloof from things: language). ${ }^{56}$ The comic stands apart from other literary texts in which the printed word and the compagination of the book are mere vehicles for sense and carry little or no significance in themselves. It does not only or primarily take the material world and translate it into the abstract realm of language; it also takes the invisible — speech, the sound of objects in movement or collision —and turns it into material, graphic form: ink on paper. Human speech, writing, and the onomatopoeic "language" of objects share the same frame, eroding differences between the animate and the inanimate.

Making the inanimate "speak" alongside human language in this way, and rendering visible the invisible energies that govern relationships between humans and objects, graphic fiction immerses us in a material world that is heterogeneous in nature and full of unexpected agentic forces. Its vision has therefore much in common with the new materialist perspectives explored in later chapters of this book, and particularly in chapter 5. The heavy use of onomatopoeia in comics (particularly heightened in Japanese manga) points to a specific kind of mimesis. Collapsing the distance between text and world crucial to the Aristotelian theory of mimesis, the comic mani- 
festly participates in material processes as well as representing them. Instead of converting material experience into discourse (as a literary text would), the particular combination of text and image in graphic fiction allows for specific kinds of rematerialization.

Herein lies, perhaps, its power to evoke the experience of walking through a modern city. In Benjamin's Arcades Project, as Gilloch claims, "Not only does one encounter the city-as-text but, more important, the text-as-city." The text becomes "the site of shock and ambiguity, of the heterogeneous and paradoxical," a montage of "diverse, eccentric figures," presenting the unknown at every turn of the page. ${ }^{57}$ Barreiro's comics likewise confront us with the "shock" of modernity in their predilection for montage, excess, and the unexpected. They also, like Benjamin's work, prepare us for that experience and help us to assimilate it. If postmodern reflexivity is "an untiring reminder to the reader that he or she is reading a text, a language, a fiction, and not viewing the world without mediation," ${ }^{58}$ graphic fiction triumphantly recuperates the work of mediation as its defining feature and one that is crucial to its cognitive operations. As a self-appointed mediator between the reader and the world beyond the text, the comic maps out points of orientation in fields as diverse as ecology, space exploration, class war, dictatorship memory, popular culture, and the classic texts of world literature. Crucially, however, its acts of translation and transmediation are also ones of (re)materialization, returning language to its place in a world of things and inscribing reading, writing, and illustrating as embodied, sensorimotor practices. 


\section{3 / Time, Technics, and the Transmission of Culture}

Alberto Vanasco's "Post-Bombum" (1967) is a prime example of the recurrent and reflexive concern in Argentine science fiction with questions of cultural transmission and the role of literature and the arts in future societies. In a postnuclear world, three men realize the importance of writing down everything they can remember and teaching the few surviving children the basics of human history and scientific knowledge. With the aim of creating a kind of encyclopedia to help a new generation condemned to start everything from scratch, they rack their brains for facts about Roman emperors, Pythagoras's theorem, and Newton's law of universal gravitation. When one of them suggests including an entry on literature, the idea is quickly dismissed: "No, literatura no. Tenemos que poner cosas fundamentales. Por ejemplo, ¿qué es una bomba atómica? ¿Cómo se hace? Eso sería muy importante" (No, not literature. We have to put essential things in. For example, what is an atomic bomb? How is it made? That would be very important). ${ }^{1}$ Without the moral and ideological matrix of literature, and its role in cultural transmission from one generation to the next, we are led to suspect that this new society will charge even faster into the errors of the old.

Vanasco's apocalyptic scenario would seem to reinforce Francis Fukuyama's claim that, for good or for ill, the development of modern science follows an irreversible path. Fukuyama argues that even a global nuclear catastrophe would not prevent science from reasserting itself as a crucial and determining element of human civilization. Given the relationship between science and war, humanity would quickly reinvent the technology that had 
brought about the catastrophe in the first place, for "even if one could destroy modern weapons and the specific knowledge of how to produce them, one could not eliminate the memory of the method that made their production possible." 2 This argument concerning the irreversibility of modern scientific advance becomes the primary defense for Fukuyama's main thesis in The End of History and the Last Man, justifying his argument for the existence of a universal, directional history that brings about uniform social changes, in time, across different nations and cultures. ${ }^{3}$

This chapter explores three Argentine novels, written around the turn of the twenty-first century, each of which constructs an apocalyptic or postapocalyptic scenario in order to propose the dramatic reversal or fragmentation of this apparently irreversible path of science. At the same time, they challenge the broader implications of Fukuyama's theory, its Hegelian optimism, and particularly its central claim that all the world's states are bound, by the forces of history, eventually to become liberal democracies and to embrace capitalism as a natural consequence of an inevitable scientific evolution. If these novels reject the notion of a universal history, however, they do not abandon the historicity that many critics have found to be a defining feature of the science fiction genre. By disrupting, superimposing, and reversing temporalities, the writers denaturalize the course of history, showing it not to be governed by some kind of universal and inevitable directionality, but by a series of decisions that are political in nature.

The three texts discussed here are linked by a central theme: the question of the transmission of culture in a society descending rapidly into chaos and brutality. Rafael Pinedo's Plop (2004) presents a desolate vision of the triumph of barbarism in a postapocalyptic wasteland, as the last book owned by the tribe, the sole vestige of textual and scientific culture, is cast into the mud. In Pedro Mairal's El año del desierto (2005), Argentina regresses at vertiginous and ignominious speed back through its history, with books and learning quickly jettisoned as the difficult business of survival takes over in an increasingly dangerous world. Eduardo Blaustein sets his Cruz diablo (1997) in a nation that is fatally bound to the conflicts of the past but that has lost contact with its cultural heritage: even the artificial implants citizens use to enhance their skills, knowledge, or moods cannot prevent the art of singing from dying out altogether. All three novels investigate the codependence of culture and technology, a relationship that will be traced with reference to Bernard Stiegler's work on the role of technics in the transmission of culture. Their understanding of the evolution of human society moves decidedly away from the social-Darwinist paradigm that dominated 
the greater part of nineteenth- and early twentieth-century science fiction, both in Argentina and elsewhere. The alternative conception that emerges in these texts coincides instead with recent work in the philosophy and anthropology of evolution that - taking issue with the nativist theory that behavior is hard-wired into our genes-emphasizes the role of social learning and cultural transmission in the development of human society.

The fear of social and cultural degeneration, a common theme in many nineteenth-century literatures, has persisted as a significant narrative topos in Argentine science fiction throughout the twentieth century and beyond. El año del desierto and Cruz diablo draw on, and interrogate, the enduring power of nineteenth-century discourses of civilization and barbarism in Argentina. In their depictions of apocalypse and endings, they return insistently to the nation's beginnings. They do so in order to reflect on the nation's dramatic decline during the twentieth century from the apogee of its affluence, political stability, and industrial advance around I880-1910, as well as to focus on the violence of the military dictatorship of $1976-83$ and the more recent financial collapse of 200I. The future society envisioned in these novels, and in Plop, is one that is deeply segregated in class terms, brutal in its repression of rebellion and difference, and that has atomized into warring tribes. Its members are entirely bereft of the social or economic protection that might be afforded by a responsible and effective central government. In other words, the nation these novels project into the future clearly bears the legacies of the political and economic crises of the past and present.

Plop, El año del desierto, and Cruz diablo might be classed as a kind of "antiscience fiction": while set in the future and written in an apocalyptic key, these novels imagine the loss of scientific culture or the reversal of technological advance. I maintain, however, that these novels are best approached as a specific branch of the science fiction genre. They clearly differ from fantastic literature in the attention they pay to causality and the historicist and materialist explanations they offer for the social changes they present. Furthermore, in all three cases, the principal focus remains on the decisive impact of technology and scientific knowledge on the evolution of culture and society: the difference is merely that these writers do not explore the consequences of new advances in science-as in most science fictionbut of their sudden reversal. By historicizing book culture as just one (albeit lengthy and significant) stage in human evolution, these texts place less emphasis on the discursive constructs of literature than on its material qualities as a technical support for cultural transmission. They subject the linear temporality of modernity to a consistent displacement and defamiliarization 
and encourage us to adopt an alternative perspective on the evolution of human society that challenges the idea of progress at the heart of modernity and capitalism. They suggest that it is not that the advent and obsolescence of different technologies become markers for social and cultural development, but that—as Stiegler argues—our sense of time itself is structured by the use of technics.

\section{Cultural Transmission, Apocalypse, and the End of History in Plop}

It rains constantly on the vast plain inhabited by a few nomadic tribes, who are well practiced in the cruel and degrading art of survival in a postapocalyptic world. An unspecified catastrophe-ecological, military, or both-has laid the countryside to waste, with contaminated rivers running through mounds of the remnants of civilization: fetid rags and rusting tin cans. Virtually everything that can be eaten or recycled has already been gathered. With a quasi-anthropological rigor, the narrator records the rites and taboos of these new societies. Sexual acts, performed at a whim and in public, are not subject to taboo but a very important part of group relationships. Indeed, the verb "to use" reserved for this practice- "lo usó" (she used him), "se dejó usar" (he allowed himself to be used), "fueron usados" (they were used) - is denaturalized, stripped of any association with abuse: rather, it is perhaps the highest form of honor accorded to another person in a society of scarce resources, only sustained by the painful eking-out of all goods. "Reciclar" (recycling) is the euphemistic description given to the use of human body parts upon death: hair, skin, teeth, flesh; even the femur can be made into a flute and bartered.

The tribes have little use for anything that cannot be eaten or exchanged for food, and Pinedo charts the total decline of literacy skills and the eclipse of the knowledge economy. On one memorable occasion in Plop's childhood, the oldest woman in the tribe gives a public reading from the last remaining book, which sketches out what we would recognize as the "Big Bang" theory of the origin of the universe. The young protagonist doesn't understand a single word, but is mesmerized, like the rest of the crowd gathered to listen, by the sound of old Goro's voice, which, "sonora, clara" (resonant, clear), sends the audience into a trance-like state. ${ }^{4}$ Despite his boredom, Plop notices the startling effect of Goro's performance on the crowd and observes that the old woman seems much taller than usual. Reading has fallen into disuse, and the skill is learned by very few; Goro, selecting Plop 
as her disciple, takes him to another tribe to be taught to read and entrusts the Big Bang text to him on her deathbed.

Plop is not a good choice to carry the burden of cultural transmission for the tribe's future generations. His descent into power-crazed cruelty and evil is shocking even by the tribe's own standards. Toward the end of the novel, in a final attempt to regain his waning authority, Plop tries to repeat Goro's trick. He flourishes the papers he has kept and announces, "Voy a leer" (I'm going to read) to the gathered audience, just as Goro had done many years previously. Yet despite his attempt to reproduce the exact conditions of the miracle, the people are unimpressed at the sight of the papers; he reads with difficulty, tongue-tied, and no one listens. Plop's reign of terror has brutalized his people, who have long since lost all interest in history, myth, science, or any ideas that do not immediately serve the task of survival. As Plop, the last reader of the tribe, throws the only remaining written text into the mud, he effects the total erasure of literary culture and casts into oblivion one of the most powerful scientific models to date to explain the origins of the universe. He will soon meet the same fate as the book. Human culture appears destined for certain distinction: the tribe has been decimated through violence and starvation, the radiated landscape is completely infertile, and little remains from which to fashion tools. This is the scenario that Fukuyama could not envision: a society that has entirely lost contact with its past, and has no means of reconstructing the methods by which it arrived at a knowledge of the natural world. ${ }^{5}$

If human culture and memory in Plop is entirely erased, to the point that "nunca existió otra cosa que barro" (nothing had ever existed apart from mud), ${ }^{6}$ it is clear that this is the consequence of a crisis in social learning and cultural transmission. In his recent work on what makes human evolution unique, Kim Sterelny emphasizes the "special role" of cultural learning, which ensures the intergenerational transfer of social and ecological knowledge and explains why the human trajectory differs so remarkably from that of our nearest ape relatives. "Apprentice learning," which Sterelny observes to be a particularly powerful way to acquire complex skills, is evidently dying out in Plop's world: the groups learning to read quickly dwindle, as do the henchmen Plop trains: given the scarcity of resources and the violence within and between tribes, there is simply no one else left to train. The fate of human society in Plop resonates strongly with Sterelny's account of the extinction of the Neanderthals. Forced by environmental changes into small groups of decreasing size, the Neanderthals, whose relatively sophisticated methods of hunting depended on "extensive cognitive capital," were increas- 
ingly unable to preserve their skills and transmit them to future generations. ${ }^{8}$ As Sterelny claims,

If survival depends on the cultural transmission of large amounts of information and expertise, the chance of survival goes down as group size declines. Such transmission is less robust, more fragile and noisy, as groups become small and isolated. ${ }^{?}$

This is precisely the scenario that leads to the destruction of human culture in Plop.

Sterelny's principal claim in The Evolved Apprentice, that "the distinctive character of human social life depends on the accumulation, preservation and intergenerational transmission of cognitive capital," ${ }^{10}$ broadly complements Stiegler's argument for the central role of technics in human culture. Drawing on the earlier work of the archaeologist and anthropologist André Leroi-Gourhan, Stiegler asserts the primordial importance of tool use in the formation of the human, countering the view that human uniqueness may be principally located in the size of the human brain, in language, or in consciousness. He argues that human consciousness is made possible by technics, which has nevertheless been "repressed" in Western philosophy from its very origins and remains "unthought." ${ }^{11}$ It is through a process of exteriorization, in which memory is inscribed in tools or objects that outlast the individual, that we are able to draw on a collective repository of skills and experiences, "to adopt an experience, to make it part of one's own past even if one did not live it oneself." 12

Plop demonstrates the crucial role of technics in the development of human culture and emphasizes that we do not approach technology as alreadyformed human subjects; instead, technology and the human coemerge and remain codependent. If technics has made possible the prodigious advance of human culture, Plop reminds us that the latter is also, by that same token, vulnerable to collapse and even erasure, with the loss of the material supports used to transmit knowledge from one individual or generation to another. Given the exactitude of its recordings, writing represents for Stiegler a particularly powerful form of technics, permitting "a new possibility of access to the past." ${ }^{13}$ In Plop, the book-the repository par excellence of cultural memory and learning - is obliterated, and along with it all knowledge of recent advances in human culture, as the tribes descend with an almost unthinkable swiftness into ignorance and indifference.

Reading Plop continually reminds us of our own access to a repository 
of cultural and scientific knowledge that is now unavailable to the novel's characters. We become involved in conscious acts of (re)cognition: when we learn, for example, that the ubiquitous mud is faintly luminescent in the dark, we infer that it must be radioactive and therefore highly likely to be the source of the cancers suffered by many inhabitants. We become acutely aware that our reading of the novel relies heavily on a preexisting knowledge of science and postapocalyptic science fiction, which includes representations of nuclear holocaust and environmental catastrophe. What makes Plop a particularly unusual contribution to the apocalyptic strain of science fiction is that the paucity of its vocabulary and the limitations placed on narrative observation (the narrator restricts himself to the relating of bald facts) do not allow for the kind of scientific or pseudoscientific excurses, the speculative reasoning or the moral treatises usually associated with the genre. One of Pinedo's triumphs in Plop is to develop a pared-down language that bears the ravages of the tribe's own regressions, acting as witness to the impoverishment of culture and science. Brief sentences of very simple syntactical composition are arranged in short paragraphs, often of a single sentence, and the repetition of certain words, phrases, and structures mimics the poverty of resources in Pinedo's imagined society. The carcinogenic effect of postnuclear waste is observed in the text in the most unscientific of terms: "había que alejarse, para que las mujeres no empezaran a parir hijos deformes y a la gente no le crecieran bolas de carne desde adentro" (you had to keep away, so that the women didn't start giving birth to deformed babies and lumps of flesh didn't grow inside people). ${ }^{14}$ Describing cancer as "lumps of flesh" that grow inside the body estranges us from contemporary science, returning us to a state of knowledge that predates advances in molecular biology that can now explain more precisely the relationship between ionizing radiation, DNA mutation, and cancerous tumors.

Plop certainly taps into twentieth-century fears of ecological disaster and the exhaustion of the world's resources, themes common in science fiction as well as other genres of literature. It may also-at more of a stretch, perhaps-encode a specifically post-200I rejection of the moral bankruptcy of neoliberalism, as Zac Zimmer suggests in his analysis of the novel. ${ }^{15}$ However, the novel's stark narrative, stripped of virtually all historical and geographical markers, acquires the universality and the moral framing of a fable; it encourages reflection on the evolution of human society in the broadest possible sense. Its overriding, reflexive concern is with the destruction of the printed book itself, as the pinnacle and greatest motor of human knowledge and civilization. Just as they have flourished in tandem, scientific 
and literary culture meet their end together. As Patrick Parrinder reminds us, "Galileo's discoveries consist of what he is able to write down, not of what he literally sees through his telescope."16 Significant scientific advancement is inconceivable in the absence of a text-based culture. Plop imagines a scenario that Fukuyama found unthinkable: the total erasure of scientific knowledge and culture and the bestialization of the human race. As a work of what I have referred to as "antiscience fiction," Plop adds nothing to our knowledge of science or its potential future developments, but much to our understanding of the conditions and material supports that are indispensable for the transmission of scientific ideas and cultural memory.

\section{Evolution in Reverse: Post-Darwinism and} Mnemotechnics in El año del desierto

Pedro Mairal's El año del desierto also stages the rapid degeneration of society into barbarism, but maps it very precisely with reference to the local and national. At the novel's opening, the decline in technology in Buenos Aires has already begun: mobile phones are no longer in use, television broadcasts are curtailed, and although the protagonist María still has a computer on her office desk, the system stopped working several months ago. This decline accelerates to a bewildering speed as the unexplained phenomenon of "la intemperie" (the battering elements) ${ }^{17}$ sweeps in a destructive wave toward central Buenos Aires, razing buildings to the ground. The affluent Barrio Norte is transformed into a slum, besieged by the homeless who are camping out in doorways, in tents, or under sheets of cardboard or corrugated iron. It becomes clear that this is just the first stage in a much broader, apocalyptic transformation in which the nation is beginning to cycle backward through its history. The capital shrinks, reversing its process of expansion: as the mighty Avenida del Libertador withers to a tree-lined lane and whole neighborhoods are reduced to scrubland, María observes that "el campo se estaba comiendo la ciudad" (the country was swallowing up the city). ${ }^{18}$ We are transported back to the power struggles of the nineteenth century, as the frontier with indigenous tribes rolls backward toward Buenos Aires and competing armies battle for ascendance in a yet-to-be-unified nation.

Unlike Plop, then, El año del desierto is firmly rooted in the political and economic history of Argentina. Critics writing on the text have traced some of the numerous ways in which Mairal's apocalyptic vision is stoked by the experience of the Argentine Crisis of 200I, in which the collapse of the peso 
and a run on banks provoked widespread social unrest and political instability, while plunging a large proportion of the country into poverty. ${ }^{19}$ Mairal's novel clearly references what have become iconic images of the Crisis and its aftermath, such as the sudden increased presence of the homeless on the streets of Buenos Aires, and the appearance of horses and carts in the city center, driven in from the city's peripheries by cartoneros to collect recyclable goods from domestic waste. More than this, however, it effectively evokes the sense of helplessness and the loss of state protection that characterized the experience of so many during the Crisis, and envisages a swift descent into utter chaos that was all too imaginable during its worst weeks and months.

Like many Argentine novels and films of the late I990s and early 2000s, El año del desierto incorporates an acerbic critique of capitalism and the blood-sucking finance industry. The only building left standing in Buenos Aires at the end of the narrative is the tower block owned by the investment company Suárez \& Baitos, whose executives have turned to cannibalism to preserve themselves at the expense of the rest of society. It is perhaps no coincidence that the tower block in question, Torre Garay, shares its name with Juan de Garay, Spanish conquistador and one of the founders of the city of Buenos Aires. ${ }^{20}$ According to the account of another conquistador and chronicler, the German Ulrich Schmídel, the early Spanish settlers of Buenos Aires were indeed driven to cannibalism as a means of survival. ${ }^{21}$ Here and elsewhere, Mairal constructs an unbroken line of economic exploitation and mutual self-destruction linking present-day Argentina to its nineteenth-century conflicts and back to the Spanish colonizers. While the novel advances forward through a twelve-month period of María's life, it simultaneously rewinds backward through Argentine history, racing back through the turbulent nineteenth century to the pre-Independence viceroyalty of Spain. As María A. Semilla Durán observes, this interweaving of time frames allows Mairal to create a series of displacements that "indican los mismos brotes de barbarie a lo largo de toda la historia" (point to the same outbreaks of barbarism throughout history). ${ }^{22}$ The effect is to place recent events, including the brutal treatment of the disappeared by the military regime, within a broader historical narrative of violence and exclusion. Zimmer likewise finds that novel's unusual chronology permits a critique of the present to be combined with a historicizing perception that "the beginning already carried the seeds of the end." ${ }^{23}$

This narrative compression of history is heightened by the novel's inclusion of a wealth of literary allusions. As the narrative retreats further into the past, Mairal's story of outlaws and deserters in the pampas of Argentina takes 
on the themes and modes of nineteenth-century literatura gauchesca. His narration of the descent of Argentina into barbarism is insistently framed by references to, and rewritings of, texts by a number of the nation's foundational or most iconic authors. María comes across a slaughterhouse clearly intended to evoke the brutal scene of animal and human butchery in Esteban Echeverría's El matadero (1838) and, like her namesake in that author's narrative poem La cautiva (I837), she is captured and enslaved by Indians. Like Echeverría, Mairal finds something of dignity and value in the "savagery" of these indigenous societies and tempers his critique with a partial rearticulation of the Romantic exaltation of nature and traditions associated with the land. When María reflects that "debajo de la ciudad, siempre había estado latente el descampado" (beneath the city, the waste ground has always lain latent"), ${ }^{24}$ she calls to mind the conflict between city and country dramatized in seminal novels and essays by Domingo Faustino Sarmiento and Ezequiel Martínez Estrada, and the persistent depiction in Argentine discourse of civilization as something precarious and always subject to threat from an underlying barbarism. Julio Cortázar's famous short story "Casa tomada" (1946) is appropriated as a means of heightening the cultural and political resonance of the imagined incursion of the homeless into the middleclass dwellings of the affluent Barrio Norte. Cortázar's protagonists-the endlessly knitting Irene and her brother-reappear in El año del desierto, dislodged from their house by squatters, a fate now replicated across the whole neighborhood.

The role of such densely woven literary references in deepening the novel's compression of history is particularly evident in the rewriting of a stanza taken from Borges's poem "Fundación mítica de Buenos Aires." The opening lines of the original poem read as follows:

¿Y fue por este río de sueñera y de barro que las proas vinieron a fundarme la patria? Irían a los tumbos los barquitos pintados entre los camalotes de la corriente zaina.

And was it along this drowsy, muddy river that the prows came to found my country? They would have lurched and reeled, those little painted boats, among the water plants in the dark brown current.

María discovers the following verses scribbled in a neighbor's notebook, a parodic version of Borges's own: 
¿Y fue por este río de sueñera y de sangre que las vuelos vinieron a arruinarme la patria? Irían con sus chumbos los milicos pintados arrojando los cuerpos a la corriente zaina.

And was it along this drowsy, bloodied river that the flights came to ruin my country?

They would have had their revolvers with them, those painted soldiers,

throwing the bodies into the dark brown current.

The altered phrases, rendered in italics above, unmistakably refer to the ruinous violence of the dictatorship of 1976-83, and specifically its favored method of "disappearing" the bodies of dissidents: throwing them from airplanes into the sea. The confidence expressed in the last line of Borges's poem, in which he states of Buenos Aires that "la juzgo tan eterna como el agua y el aire" (I judge it to be as eternal as water and air) has turned out, in Mairal's imagined future, to be horribly misplaced. The appropriation of Borges's poem thus throws into relief the role of the military's crimes in undoing the nation and shattering its dreams and ambitions, contrasting the ruin of the present with the hope of the past.

The foundering of the nation's prosperity is made all the more poignant in Mairal's interweaving of an inversion of James Joyce's "Eveline" into the narrative. Like Joyce's Eveline, Mairal's María is courted by a sailor called Frank, who asks her to leave with him and settle down with him in a new country. Neither Eveline nor María can bring herself to leave; they therefore lose the opportunity they are given to escape oppression, and both abandon their Franks at the docks. But the new life Frank offers Eveline in Joyce's story was to be spent in Buenos Aires, which in 1904-the year in which "Eveline" was written-represented a land of promise and freedom. Mairal reverses the trajectory, having María stay in a poverty-stricken, repressive Buenos Aires rather than travel with Frank to start a new life in Dublin. In doing so he mimics the shift from immigration to reverse migration that takes us from the first heady decades of Argentine economic strength in the twentieth century to years following the Crisis of 200I, which saw the grandchildren and great-grandchildren of European immigrants flee the country in search for jobs and a better life in Europe. ${ }^{25}$

As Semilla Durán observes, this is "un apocalipsis criollo, hecho de retazos de sueños o de cuerpos deshechos" (a Latin American apocalypse, made from fragments of dreams or broken bodies). ${ }^{26}$ The literary haunt- 
ings of $E l$ año del desierto consistently show us the shattered dreams at the heart of this apocalypse, presenting the city and the nation as mythological constructs as well as material ones. They do so in ways that resonate with Benjamin's approach to Paris in The Arcades Project (1927-40): like Benjamin, Mairal cannot approach the real city without first immersing himself in the mythopoetic power of its literature. The material city is always overlaid and interwoven with the imaginative visions it has inspired. As she walks through the city, María's journey is one that does not merely take her through its many spaces, and backward through its history, but also through the pages of the many works of literature it has prompted. The city is composed of these texts as much as it is by streets, blocks, and gardens. On the first night that she spends in the city center, María hears the three shots that kill El Rufián Melancólico in Roberto Arlt's Los lanzallamas (193I) and sees his body lying on the street. The underworld setting and slang of Arlt's novels are perfectly evoked in the (invented) phrase that Mairal gives to one of the killers: "Andá a saber qué inmundicia venía pensando el muy cafisho" (Who knows what filth that pimp was thinking about). ${ }^{27}$ In an interview, Mairal acknowledges that

a mí me interesaba mostrar una Buenos Aires sintáctica, donde si el personaje atravesaba Diagonal Norte y Suipacha, pasaba por el lugar donde lo mataron al rufián melancólico de Arlt en ese momento, como si existiera una Buenos Aires hecha de párrafos de la literatura argentina. ${ }^{28}$

I wanted to present a syntactic Buenos Aires, where a character crossing the junction of Diagonal Norte and Suipacha would pass through the place where Arlt's Rufián Melancólico was killed at that moment in time, as if there existed a Buenos Aires made up of paragraphs from Argentine literature.

Semilla Durán suggests that Mairal's citations, inversions, and transpositions of literary narratives dismantle the national canon, producing unorthodox meanings as they are transplanted into different contexts. ${ }^{29}$ Mairal certainly demonstrates that literature, so key to the establishment of Argentina's founding discourses, is also heavily implicated in its disintegration, as a space in which the nation's contradictions, conflicts, prejudices, and exclusions are given voice. From the racial stereotyping of nineteenth-century fiction and its polarizing of city and countryside, to the dangerous streets 
of Arlt's novels or the middle-class anxieties of Cortázar's "Casa tomada," Argentine literature has played an important role in constructing and magnifying the exclusionary discourses that have shaped the nation's evolution to the present day.

Semilla Durán's acute observation that Mairal's recognizably Latin American apocalypse is constructed from "broken bodies" as well as shattered dreams points to another possible reading of the novel, however, which places much greater emphasis on the material and on direct sensory experience rather than the sublimations of literature. On this reading, Buenos Aires is not set up for - or even hastened toward — ruination by the nationalist fantasies or the exclusionary rhetoric of its literary discourse; this comes instead as an inevitable consequence of the demise of cultural technologies, of which the literary text is one.

Mairal's emphasis on the frailty of Argentina's nation-building and civilizing projects might be seen to resurrect and reinforce the nation's founding literary myth of civilization and barbarism, presenting the twenty-first century's advances as nothing more than a veneer that is quickly erased in the nation's regression back to its barbaric origins. However, his understanding of progress and evolution does not entirely fit within the Darwinian framework that informed so many nineteenth- and twentieth-century literary and political texts in Argentina, from Sarmiento to Lugones, Quiroga, and Arlt. These writers sought to understand human evolution as a function of genetics, to emphasize the shared biological heritage of humans and monkeys, or to apply the dynamics of natural selection to human advancement. One might think, for example, of Sarmiento's racialized narratives, the disturbing human-ape fusions and regressions of Quiroga's "El mono que asesinó" (1909) or Lugones's "Yzur" (Las fuerzas extrañas, 1906), or Arlt's emplotment of Darwin's "struggle for life" in El juguete rabioso (1926). By contrast, Mairal demonstrates the extent to which human culture does not simply evolve according to Darwinian natural selection, but is artificially accelerated by means of technics. His vision corresponds much more closely to that of Stiegler, for whom technics supports a transmission of culture from one generation to the next, "a new form of memory that can no longer be inscribed in Darwinian terminology." ${ }^{30}$ While individual memory is erased at the moment of death, "Inheriting and adopting a tool means inheriting a part of the experience of the one(s) who bequeathed it: it is to adopt an experience, to make it part of one's own past even if one did not live it oneself." ${ }^{11}$ This is why Stiegler emphasizes the importance of adoption, rather than adaptation, in the evolution of human culture. 
Mairal's choice to chart the evolution of society in reverse in his novel has an important estranging effect, heightening an awareness of the relationship between the development of technics and the evolution of human society and culture. The sheer speed with which Argentina's progress is unraveled is, of course, fantastical and hyperbolic, but it does draw attention to the pace of historical development from the nineteenth century to the present day, a speed that cannot easily be explained with reference to the extremely slow pace of gene-based evolution. For Stiegler, and for Mairal, it is technics that comes first, giving rise to changing forms of human culture. In $E l$ año del desierto, as supplies of antibiotics and surgical instruments start to run out, the hospitals of Buenos Aires have to resort to premodern practices such as bloodletting, homemade poultices, and the use of cupping glasses. Such desperate measures have an immediate effect on beliefs and practices more widely: in the provinces, science is replaced by superstitious practices and spiritual healers, while the village priest preaches against technology and progress and calls his congregation to return to laboring on the land.

It is at this point that Mairal's novel definitively parts company with Echeverría's more Romantic vision of premodern culture. Mairal shows us beyond a doubt that antitechnological idylls are rooted in slavery and the oppression of women, and that, bereft of certain specific scientific and technological objects, we would quickly lose the social advances that accompanied their introduction. The loss of IT systems initially enhances sociability among workers and neighbors in Buenos Aires, but feudal instincts soon take over as the nation careers backward through history toward an evergreater state of dissolution and repression. Women lose the vote and the provinces fall again under the power of caudillos. The rapid erasure of technological supports reveals the extent to which social and cultural evolution is dependent on the history of technology.

The written book, we are led to understand, is only one stage in the development of human culture, and as transient as any other technology. In fact, books are among the first objects to be jettisoned in the battle against the "intemperie" and the fleeing hordes. With deep irony, Mairal describes the confiscation of all books in Buenos Aires, commandeered for the purpose of building barricades designed to keep the encroaching provincial masses out of the city proper, in a last and ultimately futile attempt to shore up the privileges of the social and cultural elite, who are perfectly ready to sacrifice their accumulated wealth of knowledge and learning in order to defend their private property. However, Mairal's depiction of the primitive Ú tribe, with whom María enjoys relative peace and equality, suggests that-unlike 
in Plop-the loss of literate culture does not mean the loss of human civilization. As María reflects, "Yo abandoné mis ideas de alfabetizarlos. No le encontraba sentido. ... ¿ Para qué enseñarles a fosilizar su conocimiento, si les iba cayendo como el agua de generación en generación?" (I abandoned my idea of teaching them to read and write. I couldn't find any reason for it. ... Why teach them to fossilize their knowledge, if it drips like water from one generation to the next?). ${ }^{32}$ The tribe may not be literate, but its members are not lacking in the kind of ceremonies and collective practices that-along with archives, maps, and all forms of prosthetic memory-make up what Roger Bartra refers to as the "exocerebral networks" that complete the neuronal circuits of our brains and that allow for intergenerational transmission. ${ }^{33}$

With the Ú tribe, María finds that "el tiempo se dejaba habitar" (time allowed one to inhabit it): ${ }^{34}$ there is a harmony between the state of technical evolution and social evolution that Stiegler finds to be especially elusive in our own era, given its increased rate of innovation and change. ${ }^{35}$ Mairal's representation of the tribe cannot be dismissed as a nostalgia for a preindustrial era, however: he leaves us in no doubt concerning the tribe's suffering through lack of medical treatment, for example. Instead, the key purpose of this episode within the narrative of El año del desierto is to demonstrate the fact that what makes us human is the capacity and desire to use tools to shape the environment around us rather than merely to adapt to it, and to preserve and transmit culture beyond the span of our own lives, through whatever technical objects may be fashioned from the materials around us. Literary culture, Mairal suggests, is just one way that we have experienced and shaped the world, and not necessarily the most sensuous or immediate.

Carl Freedman argues that "science fiction and the novel of historical realism both involve a Lukácsian dialectic of historical identity and historical difference," as both draw attention to what separates or unites the present with the future or the past. ${ }^{36}$ Mairal's novel, as we have seen, can certainly be placed within this historicizing matrix, providing a robust demonstration of the historical and realist grounding of science fiction. However, it goes further to suggest the extent to which technical developments are not simply markers of historical time, but-as in Stiegler—responsible for creating an awareness of time itself. It is the memory preserved in the tools and artifacts that precede and survive us as individuals that, as Ian James explains, "constitutes us, at a fundamental level, as temporal beings who are aware of a past, experience a present and anticipate a future." ${ }^{37}$ Within this same logic, in Mairal's novel, as in Pinedo's Plop, it is the disappearance of such material supports that erases both the past and the future. The apocalypse it imagines 
is therefore not so much the end of the world (or Argentina, at any rate) and the advent of a new one, so much as the end of time through the loss of the cultural and technical memory that has underpinned human evolution. The last few humans in Argentina are destined to die out quickly as they turn to cannibalism, while salvation and regeneration is to be found only on the other side of the Atlantic, in a silent library where María is eventually able to recover, surrounded by books and old maps.

\section{Cruz diablo: Technics, Psychopower, and the Cybernetic Gaucho}

Eduardo Blaustein's Cruz diablo plunges the reader into an alternative temporality, in which certain aspects of Argentine society have progressed into the future while others have regressed into the past. The country is strewn with the relics of old machines and screens, many of which surpass our own technological achievements but are now obsolete or beyond repair in the novel's narrative world, like the three-dimensional hologram on the city bus that flickers and cracks up. The Central City, the seat of the country's weakened military government, stands adjacent to the old Buenos Aires. If Buenos Aires now boasts more shire horses and carts than cars, things are not a great deal better next door: even the Central City has no budget for repairs to its lighting system. Outside of the cities, most of the country's population lives in "villas virtuales," slum enclaves whose pacified inhabitants are permanently connected to an image generator, while others live in a land of frontier towns, strongholds, and Indian camps.

The novel appears to take place in the future, and there is mention of the aftermath of a large-scale napalm attack in one region of the country. On the other hand, aspects of the novel immerse us in a recognizably nineteenthcentury scenario of indigenous uprisings, warring regional governors, and territorial disputes with neighboring Chile and Brazil. Still other references place us in the more recent past, with continual references to the armed revolts of the Montoneros in the I970s and the repressive military response. Fascinated by the uniquely perverse trajectory of Argentine history, some Germans arrive to make a documentary about the nation. They explain that the country is now the product of divergent temporalities: "Hay algunos pedazos de Argentina y otros que eran Argentina que es como si hubieran dado una vuelta de campana en el tiempo" (There are some bits of Argentina and others that are Argentina as if it had somersaulted backward in time). ${ }^{38}$ Time has not simply flowed forward, they claim; at a moment of crisis, it 
also began to move backward. The tangled temporalities of Cruz diablo allow Blaustein to conflate several historical periods into one in order to mark essential continuities between them, in an even more radical fashion than in El año del desierto.

Cruz diablo offers several potential explanations of the crisis it depicts, many of which paint a satirical picture of an Argentine modernization that turns out to be nothing more than a veneer of progress. It is clear that social change has not kept pace with technological advance: instead, national identity continues to be defined by unresolved conflicts from the recent and more distant past. We might read this as a hyperbolic instance of the relationship Stiegler observes between the technical system and the social system, in which the former is always in advance of the latter, meaning that "the transformations of the technical system regularly bring in their wake upheavals of the social system, which can completely destabilize it," ${ }^{39}$ and "the adjustment between technical evolution and social tradition always encounters moments of resistance, since technical change, to a greater or lesser extent, disrupts the familiar reference points of which all culture consists." ${ }^{\prime 0}$ Cruz diablo implies that Argentina is characterized by the persistence of precisely such disjunctures between technological advance and social and cultural backwardness.

Moreira, the novel's protagonist, is fascinated by the theory of the "Hombre Aturdido" (Bewildered Man), widely held in a previous generation. The theory proposes that man, unlike other animals, reached a limit in his capacity to adapt to his environment and began to show the following symptoms: "atrofia de los sentidos, anulación de las percepciones espaciales más simples, completa anulación de la facultad de enfrentar y superar las situaciones nuevas que él mismo había desencadenado" (atrophy of the senses, suppression of the most simple spatial perceptions, complete eradication of the capacity to confront and overcome the new situations that he himself had triggered). ${ }^{41}$ The rate of innovation simply outstripped man's capacity to adapt to his new circumstances:

Demasiado vértigo—se decía — para un cerebro limitado y un cuerpo fofo. Excesivos cambios y sobrecarga de estímulos y mucha aceleración y todo demasiado complejo, demasiado olvidable. ${ }^{42}$

Too much vertigo - it was said-for a limited brain and a flabby body. Excessive changes and an overload of stimuli and a lot of acceleration and everything too complicated, too forgettable. 
Having gained currency, this alarming theory led to a flight to the countryside by some of the nation's citizens, searching for their roots in the land, to a revolt by others against the state as an artificial construction, and to the rise of sects gathering to seek a solution.

The advent of cerebral implants succeeded in pacifying the majority and returning them to a state of general contentment. Implants are now available for foreign languages, or for the quick assimilation of whole degree courses; they can also cure depression or alcohol dependence, guarantee popularity or simulate journeys to Jupiter's moons. The entertainment systems of the "villas virtuales" (virtual shantytowns) keep most of the country's population in such thrall that they would forget to eat if mealtimes were not regulated. Blaustein presents a terrifying vision of the pacifying effect of mass culture within a society of control. It is one that lends support to Stiegler's view that forms of biopower are now being replaced by psychopower, exerted over citizens with the aid of the burgeoning mnemotechnical industry. While Foucault's "biopower" describes the "explosion of numerous and diverse techniques for achieving the subjugations of bodies and the control of populations," ${ }^{43}$ Stiegler's "psychopower" gains control through a manipulation of consciousness:

Psycho-power is the systematic organisation of the capture of attention made possible by the psycho-technologies that have developed with the radio (1920), with television (1950) and with digital technologies (I990), spreading all over the planet through various forms of networks, and resulting in a constant industrial canalization of attention. ${ }^{44}$

Hooked up to image generators in the "villas virtuales," the great majority of Argentine citizens in Cruz diablo are subjected to this "canalization of attention" that Stiegler describes elsewhere as a growing synchronization of consciousnesses as thousands or even millions of viewers consume the same programs at the same time across the world, ${ }^{45}$ a phenomenon that militates against individuation. ${ }^{46}$ Moreira is disturbed by such synchronization, saying of the villa inhabitants:

No sé bien qué les pasa, les hacen ver cosas, a veces las ven de a varios, de a muchos, como si todos estuvieran en una sola cabeza. Y le digo que es una cabeza muy grande, cacique, porque pueden estar miles de tipos, de distintas villas, alejadas, mirando juntos, dándole vueltas a la misma cosa. ${ }^{47}$ 
I'm not sure what the matter is with them. They are made to see things; sometimes several or even many of them see the same thing, as if they were all inside one brain. And it has to be a huge brain, chief, because there can be thousands of guys, from different villas, a long way away from each other, seeing things together, mulling over the same thing.

Technology is, then, for Stiegler, a "pharmakon," a term he borrows from Derrida to refer to its nature as both poison and remedy. Contemporary technics "reveals itself at one and the same time as human power [puissance] and as the power for the self-destruction of humanity." 48 As he explains, "Technicization is what produces loss of memory, as was already the case in Plato's Phaedrus." ${ }^{\prime 9}$ It can extend the capacity of the mind to retain information, perform complex calculations, and develop new skills, but it may also control the mind, taming it into placidity. This paradox is fundamental in the narrative of Cruz diablo, which-like Plop and El año del desierto-is centrally concerned with the question of the role of technics in the intergenerational transmission of culture.

Stiegler suggests that "the development of industries of memory, imagination, and information engender[s] the fact and the feeling of a gigantic memory hole, a loss of connection with the past." ${ }^{50}$ This is patently the scenario of Cruz diablo, in which the expansion of the mnemotechnical industry only throws into relief the rapid loss of the nation's history and cultural heritage. Moreira, a kind of cyber-gaucho, travels the length and breadth of the territory to gather diverse songs, stories, tools, machines, and other repositories of social and cultural knowledge that have fallen into disuse or been entirely forgotten. These are rare vestiges of past traditions within a population that has decided to content itself with artificial implants and virtual experiences. Moreira has been made the recipient of a neural implant transferred to him on the death of Carfi, one of the few inhabitants of the country who still has the ability to sing, an art that is inexplicably dying out. Society's reliance on technics for the transmission of culture between generations is poignantly highlighted, as the external supports carrying the memory of a nation and its evolution over time are left in rusting heaps, to be rescued and repaired only by Moreira and a few like him.

The novel's own self-conscious embedding within past literary models demonstrates their enduring power in the present, for better or for worse. As Edward King observes, Blaustein's Moreira harks back to Eduardo Gutiérrez's novel of the same name, based on a real story and published in serial 
form in $1879-80$, and inherits his predecessor's character as a nomadic outlaw and "frontier figure," wheeling and dealing with groups on opposing sides. ${ }^{51}$ Although the many rewritings inspired by the novel often cast Moreira as an icon of popular resistance and the archetypal victim of state violence, the original character-as Juan Pablo Dabove suggests-was a much more ambiguous figure. Like Blaustein's Moreira, he was prone to making pragmatic allegiances with individuals in power or to switching sides when such a move might bring economic advantage. ${ }^{52}$

Cruz diablo is also an ironic and cybernetic rewriting of Sarmiento's foundational text Facundo (1845), and particularly those passages within it that study the figure of the gaucho: the disaffected horseman who roamed the Argentine pampas and whose power-in Sarmiento's eyes — was an impediment to progress. The gaucho, living at the margins of the law and resistant to assimilation into the nation's civilizing project, nevertheless seemed to epitomize the national character, and Sarmiento betrays a clear admiration for his skills. Like the gaucho in Facundo, Moreira is reserved and serious by nature, a loner, and a man who lives with the constant presence of death. In Sarmiento's nomenclature, he resembles both the "rastreador" (tracker), who can follow the scents and trails of any animal, and the "baqueano" (expert guide), who knows, like the back of his hand, "veinte mil leguas cuadradas de llanuras, bosques y montańas" (twenty thousand square leagues of plains, woods, and mountains). ${ }^{53}$

Moreira is often described in ways that recall the gaucho way of life and the particular skills needed for surviving in the pampas. He knows how to travel around the country, "haya ruta, camino, rastrillada, huella, lo que sea" (whether by road, path, trail, animal track, whatever). ${ }^{54}$ However, repeated epithets combine the folkloric with the cybernetic: he is a "rastreador por pantalla" (on-screen tracker) ${ }^{55}$ and a "rastreador de software" (software tracker), ${ }^{56}$ who now, as a cyber-gaucho, embodies tradition in the form of Carfi's singing implant. He is described more than once as an "hombre de habilidades cambiantes" (man of changeable skills), ${ }^{57}$ and the introduction of the implant makes this more true than ever. Again like the gauchos in Facundo, Moreira's skills and knowledge are highly prized by those in power, who may learn to use them to control the populace: he has contacts in all tribes and groups and an understanding of local power struggles that is second to none. But here he is most valued, it seems, for his knowledge of arts and cultures that are fast disappearing. He is a "viajero, traficante y negociador de frontera, recopilador de artes perdidas" (traveler, trafficker, and frontier negotiator, a compiler of lost arts), ${ }^{58}$ a "viajador y recopilador de fábulas ajenas" (traveler and compiler of other's tales), ${ }^{59}$ and a "recopilador 
de datos perdidos" (compiler of lost information) ${ }^{60}$ His fascination with old machinery is likened on many occasions to his equal interest in old stories and songs that are falling into disuse.

Indeed, one of Sarmiento's gaucho types was the "gaucho cantor" (singer gaucho), whom he likens to a medieval troubadour, and who, in Sarmiento's words-much like Moreira in Cruz diablo — "se mueve en la misma escena, entre las luchas de las ciudades y del feudalismo de los campos, entre la vida que se va y la vida que se acerca" (moves on the same stage, between the battles of the cities and the feudalism of the countryside, between the life that is disappearing and the life that is approaching) ${ }^{61}$ His role as chronicler, Sarmiento claims, would be of huge benefit to a future historian, but only if there were not a more cultured society at hand, with superior knowledge of events, that is eminently more qualified to write the history of the nation. ${ }^{62}$ In Blaustein's novel, that more cultured society does not exist, or it has long since lost interest in old stories and customs, leaving Moreira one of the few remaining individuals with access to the nation's past: its folklore, legends, and forms of life.

In other respects, however, Blaustein paints a picture of a nation in which the transmission of traditions and conflicts of the past has had a radically paralyzing effect, as cultural memory serves only to entrap its citizens even more deeply in unresolvable tensions. With the help of the German documentary-makers, Julio comes to see that

es que hubo tanto revisionismo histórico, tanto revolvimos en la memoria a medida que nos hundíamos, tanto necesitábamos agarrarnos de algo, tanta provincia odiando primero a Buenos Aires y después a Ciudad Central, tanto montonerismo, indigenismo y tanto no sé qué, que al final nos descolgamos del mundo, volvimos para atrás. ${ }^{63}$

there has been so much historical revisionism, so much rummaging around in memory while we sank deeper and deeper, we had such a need to grab onto something, so many provinces hating first Buenos Aires and then the Central City, so much Montonerism, indigenism and so much this, that, and the other, that in the end we left the world behind, we moved backward.

In Blaustein's world, these internal conflicts have provided such a sense of identity through crisis that the nation is unable to move beyond them to embrace the future.

Old discourses and ideologies in Cruz diablo are either stultifying or su- 
premely ironic in their optimism concerning the nation's future. Nineteenthcentury dreams and divisions echo hollowly through the text. Descriptions of the Indians as disinclined to engage in work or commerce could have been lifted from the pages of Facundo or José Hernández’s Martín Fierro (I872, 1879). ${ }^{64}$ Moreira is presented with the gift of a miniature bust of Sarmiento with a button that causes his eyes to light up and his chin to move up and down, "como una máquina parlante de circo" (like a talking machine from the circus), as he pronounces the phrase: "Cuando haya un gobierno culto $y$ ocupado de los intereses de la Nación, ¡qué de empresas, qué de movimiento industrial!" (When there is a civilized government with the interests of the Nation at heart, what enterprises there will be, what industrial activity!). ${ }^{65}$ His words take on a grotesque irony in the context of the novel's industrial failure and the weakness and self-interest of its central government. The bust is a gift from a schoolteacher whose computer system Moreira has managed to coax into functioning again. As Fernando Reati observes, this episode presents a particularly acerbic critique of the demise of the public school system that had once been the pride of the nation; even when operational again, the school's digital library is full of outdated texts containing visions of the nation's glory that have long since been proved false. ${ }^{66}$

Cultural tradition in Cruz diablo has become a meaningless label. We discover that many of the Indians that populate the novel are not actually members of indigenous tribes or their descendents: it has become a lifestyle choice of rebellious living for those who do not wish to enter the "villas virtuales." The "Indians" speak a strange mixture of porteño slang ${ }^{67}$ inflected with an overuse of gerunds that is supposed to evoke the speech patterns of indigenous people: "Ché, boludo, contestá. . . . Así que no teniendo armas Moreira pelotudo?" (Hey, jerk, answer. . . So not having weapons Moreira dumb-ass?) ${ }^{68}$ When Moreira challenges their affected style of speech, one replies that he is

hablando como los padres de mis padres, como los antiguos. Muchos hermanos hablando así. Yo reconstruyendo memoria. Yo no siendo sometido. [ . . . ] Ramoncito, en hablando como los padres de sus padres, mostrando respeto a los caídos en la lucha. ${ }^{69}$

speaking like the fathers of my fathers, like the ancient ones. Many brothers speaking like this. I reconstructing memory. I not being subjugated. . . Ramoncito, in speaking like the fathers of his fathers, showing respect to the fallen in battle. 
Nothing of indigenous culture remains except for these empty signs and slogans, circulating in a society that has forgotten most of its true heritage but retained its age-old penchant for violence and internal divisions.

Singing, and listening to singing, are presented as a more authentic and profound way of connecting with the past, a way of recalling what would otherwise be lost but that enlightens rather than oppresses, regenerating an affective experience in a people wearied by ideological strife and depersonalized by the homogenizing effects of consumer culture. When Carfi sang,

Era ponerse a escucharlo y sentir que uno iba cambiando por adentro, como si una luz se le metiera y encontrara cosas que uno no conocía que tenía, o que sí sabía pero las había perdido, se había olvidado. Pedazos que se van perdiendo en tantos ańos, por ahí de personas o paisajes de cuando se es chico, sensaciones. ${ }^{70}$

If you started to listen you felt that you were changing inside, as if a light shone there and found things you didn't know you had, or you did know but you had lost them, you had forgotten. Bits of things that get lost over so many years, perhaps people or landscapes from when you were small, feelings.

Singing thus counters the deindividuating, synchronizing effect of mass culture, restoring a memory of an individual past.

The chief executives of the Gobierno Central, sniffing potential profits, stop at little in their quest to assume control of the Carfi implantnow stored in Moreira's brain - to test its marketability. Unfortunately, the singing implant significantly underperforms, providing a poor substitute for the original. Having survived an intensely traumatic psychic experience in which his self struggles to assimilate the other voices that entered his head along with the implant, Moreira can only manage to squeeze out three scratchy notes. The novel laments the loss of "las fuentes de creación" ("sources of creation") like Carf: ${ }^{71}$ the only music now available is a bland, formulaic, programmed variety. At the end of the novel Moreira rejects an offer to become the source of a program of stories and songs for the benefit of the bedridden inhabitants of the "villas virtuales." The corporation in Ciudad Central offers to "convertirlo en experiencia, diseñar un programa de consumo masivo con centro en Moreira" (convert him into an experience, design a program for mass consumption with its center in Moreira). ${ }^{72}$ He escapes to Brazil, having lost interest in the world, which he suspects of 
having become monotonous and uniform, there being "nada nuevo bajo el sol" (nothing new under the sun). ${ }^{73}$

Cruz diablo thus powerfully illustrates Stiegler's understanding of technics as pharmakon. In Nathan Van Camp's summary, which can be read as an apt description of the dilemma at the heart of Blaustein's novel,

On the one hand, mnemotechnics constitutes nothing less than the condition of possibility of tradition and collective memorization as such, but on the other, the industrial exploitation of the mnemotechnical system which we are currently experiencing tends toward the destruction of both psychic and collective individuation processes. ${ }^{74}$

If prostheses - the use of which is the defining feature of human cultureprovide a liberating and enabling source of knowledge and skills, they may also be co-opted by the state (or another power) for the purposes of social and psychic control. In Blaustein's very Argentine tale, another paradox is overlaid on the first: if technics connect us to the past and expand our experience beyond the individual, accumulating skills and knowledge over the generations, technological advance may fatally outstrip the evolution of social systems, or even mire us even more deeply within unresolved conflicts from the past.

\section{Conclusion: The End of (Universal) History}

Although Plop, El año del desierto, and Cruz diablo imagine unfamiliar, apocalyptic worlds, they make a significant contribution to an understanding of the role of technics in our own. They do so by historicizing literary and artistic culture, charting the rise and fall of the book, examining questions of cultural transmission and exploring the cultural and social impact of mnemotechnics. If Fukuyama's theories of universal history express a desire for, and an anticipation of, a better (more liberal, more egalitarian) future, Stiegler's work on technics explores what it is that enables us to project ourselves into the future at all. His answer is that it is technics that allows us to understand ourselves within time and to construct a horizon of temporality, as it is what frees us from the daily battle for survival and enables us to create a future for ourselves that is not determined by our adaptive capacity. These three novels share this insight, observing the tightly coevolved relationship between human culture and its material tools and inscriptions, and by dem- 
onstrating how quickly our sense of progress, and even temporality itself, dissipates in their absence.

The dramatic reversal of Argentina's fortunes over the twentieth century provides a powerful backdrop for experiments in alternative, nonlinear temporalities that challenge a belief in a homogeneous line of evolution that all nations are destined to follow, toward greater rationality and development. These novels cannot endorse a version of history as "a single, coherent, evolutionary process" in the way that Fukuyama proposes, a belief that even he acknowledges to be difficult to maintain after the political disasters of the twentieth century. ${ }^{75}$ Any belief in the inevitability of progress-scientific, social, or moral-has been badly shaken by the events of Argentina's recent history. As Elsa Drucaroff writes, with reference to Mairal's evocation of the Crisis of 200I, "Es horrendamente fácil para los lectores imaginar, en este tiempo, un final, un desastre irreversible. No hay que leer ciencia-ficción, basta con el Clarin" (It is horrendously easy for readers to imagine, at this point in time, an ending, an irreversible disaster. You don't need to read science fiction, just read Clarin). ${ }^{76}$ In the hyperbolic temporal reversals of $\mathrm{Cruz}$ diablo and El año del desierto - and also, perhaps, of Plop —it is not difficult to detect the expression of a common anxiety concerning a nation that has dropped out of the global race and confounded linear models of historical development. The specter of scarcity hovers over the two post-Crisis novels, Plop and El año del desierto, which trace a rapid transition from a capitalist economy based on money and accumulation to one based on barter, subsistence, and feudalism.

In their emphasis on technics and cultural transmission, however, these novels move beyond their local context to explore the nature of human evolution in much broader terms. The relationship between temporality and technics will be taken up in chapter 6 , with a discussion of four films that also mount a critique of the historicist, universalizing discourses of modernity, but in which the utopian potential of technics is more clearly expressed. 


\section{4 / Projection, Prosthesis, Plasticity Literature in the Age of the Image}

Science fiction, especially since the 1950s, has typically presented a dystopian vision of the mass media as a narcotizing force of control and containment. It has underscored the passivity of the audience in the age of the spectacle and demonstrated the potential for authoritarian abuses of mass televisual practices. Ray Bradbury's Fahrenheit 45I (1953) would seem to epitomize this anxiety. ${ }^{1}$ Bradbury depicts a society in which books have been outlawed in favor of television, more suited to the shorter attention spans and the intellectual and political lethargy of a consumer society in thrall to the image. Scott Bukatman claims that in the book burnings of Fahrenheit 45I, "the overthrow of the Word is presented as tantamount to the overthrow of Reason itself, leaving an infantilized—if not barbaric — citizenry poised passively before the pseudo-satisfactions of the spectacle, bereft of the ability to think, judge, and know."2

Bukatman reads this strain of science fiction as an attempt to protect the power of the civilizing Word against the barbarizing forces of image culture. Ultimately, he claims, it expresses a fear concerning the erosion of representational truth, in the context of the increasing manipulation of digital images and electronic data. ${ }^{3}$ However, I would suggest that Bradbury's treatment of book culture in Fahrenheit $45 I$ is rather more complex: it is not presented nostalgically as the apogee of civilization, or opposed in its essence to image culture. As Faber tells Montag, books are simply receptacles for a kind of consciousness that can easily be deposited in other forms, including cinema, radio, or television: 
It's not books you need, it's some of the things that once were in books.... The same infinite detail and awareness could be projected through the radios and televisors, but are not. No, no, it's not books at all you're looking for! Take it where you can find it, in old phonograph records, old motion pictures, and in old friends; look for it in nature and look for it in yourself. Books were only one type of receptacle where we stored a lot of things we were afraid we might forget. There is nothing magical in them at all. The magic is only in what books say, how they stitched the patches of the universe together into one garment for us. ${ }^{4}$

Bradbury thus finds nothing unique about the form of the printed book that should mark it out as a privileged vehicle for this kind of cognitive mapping or for the preservation and transmission of culture. Literature is merely one tool developed by human society for these ends, and other forms of media could perform a similar role.

This chapter explores the treatment of cinematic, televisual, and other visual regimes within a selection of literary texts in Argentina, published in the 1920s, in 1940, and in 2000. It finds, surprisingly perhaps, that the relationships constructed between literature and new (or imagined) technologies of the image are not always ones of contrast or rupture, but often of similarity and continuity. Where we might expect to see a desire to shore up the status of the literary text in the face of the increasing threat of the rise of image culture, we often find instead a recognition that books are, as Bradbury suggests, "only one type of receptacle where we stored a lot of things we were afraid we might forget," or an acknowledgment that we invest both literary texts and images with similar desires, most often to immortalize our transient lives, or to reflect back to us a coherence of self or world that can only be illusory. These texts reveal an abiding interest in the apparatuses of photography, cinema, and virtual reality both as material artifacts and as technologies of materialization. Far from being understood merely as regimes of representation of a greater or lesser realism, they are presented here as intervening directly in sensual experience. Through the relationships they establish between these technologies and those of the literary text, the writers explored in this chapter emphasize their shared nature as prostheses for human thought and memory, and their determining influence on modes of human engagement with the material environment.

In Horacio Quiroga's short stories of the I920s and Bioy Casares's wellknown novel La invención de Morel (1940), new or invented technologies of 
photographic recording and the projection of moving images may arouse hitherto unimaginable desires and fears, but in many ways they simply bring into sharper focus the kind of imaginary and subjective investments that have always characterized representations of ourselves and our societies. At the same time, these texts begin to explore the changing forms of perception and subjectivity that arise from our interaction with new forms of visual technology. This is also a central aim in César Aira’s El juego de los mundos (2000), a novel that explicitly compares and contrasts traditional literary culture with a futuristic vision of a culture based entirely around images and virtual reality. This comparison does not give cause, however, for any simple lament at the passing of the age of literature, at risk of being superseded by a more powerful and image-based mass culture. In Aira's novel, literature's operations have not been rendered obsolete so much as displaced onto other forms of media and virtual reality. This enables us to grasp their shared characteristics as technologies of prosthesis. Aira's key interest is in imagining the effect this shift might have on our modes of perception and understanding.

My discussion will develop the Stieglerian perspective developed in the last chapter, according to which written texts become just one form (albeit a very effective one) of technics, or tools designed to carry cultural memory from one generation to the next. However, the literary narratives I discuss here do not ultimately, or solely, present image culture or the mass media as damaging to human processes of individuation in the way that Stiegler often does, whose work on mass culture may in some ways be read as a continuation of Theodor W. Adorno and Max Horkheimer's analysis of the detrimental effects of the culture industry. Instead, the primary concern of these texts is to demonstrate the plasticity of human perception, in ways that echo some of the insights of Catherine Malabou's work, written at the intersection of philosophy and neuroscience. My reading of these texts will prepare the ground for a consideration, at the close of this chapter, of Malabou's claim that plasticity is now replacing writing as an organizing paradigm in contemporary thought.

\section{Life beyond Death in the Cold Chemistry of Quiroga's Celluloid Screens}

Cinema arrived early in Argentina: the first of the Lumières' films was shown in July 1896 in Buenos Aires, a mere six months after the inaugural public screening in Paris; the first short films depicting the Argentine capital were 
screened there later that same year. ${ }^{5}$ Cinema's rapidly growing popularity during the early decades of the twentieth century, principally in the form of imported Hollywood films, met with a mixed response from the country's lettered elite. Fascinated by the fictional and aesthetic potential of the "seventh art," intellectuals in this period were also deeply troubled by the unchecked flow of U.S. cultural products into the country, and critical of the low quality of many of these films. ${ }^{6}$ Cinema was widely perceived as a serious threat to intellectual culture; Jason Borge suggests that, for many of its critics, it represented "una especie de erosión de su propio espacio mediático" (a kind of erosion of their own space within the media) and a loss of their monopoly over the public sphere.

Debates over the relative qualities of cinema and theater, in particular, filled the pages of newspapers and magazines. Many acknowledged, with admiration and mistrust in varying degrees, the considerable power of cinema's direct appeal to the masses. For the novelist and cronista Roberto Arlt, critical of many imported films but more open than most to the subversive potential of cinema, it may be true that cinema "idealiza la vulgaridad" (glamorizes vulgarity), but a film is far more effective than any book in arousing discontent with the social status quo. ${ }^{8} \mathrm{He}$ finds that "el cine ha suplantado al teatro en su función de Escuela Práctica de Vida" (cinema has supplanted theater in its role as the Practical School for Life); ${ }^{9}$ in an article written in 1933, he speculates about the particular power of cinema over the imagination in the sleepy, impoverished towns of Argentina's provinces, where it is performing "una tarea revolucionaria" (a revolutionary role). Here, where a bookseller would die of hunger, Hollywood's intoxicating images provide a glimpse of a life out of reach for members of the audience, trapped in poverty and the conservative customs of provincial life. ${ }^{10}$ What consequences might such discontent lead to? Arlt is not sure, but he ventures the view that "de lo que no me queda ninguna duda es que el cine está creando las modalidades de una nueva psicología en el interior" (what I have no doubt about is that cinema is creating the forms of a new psychology in the provinces). ${ }^{11}$

Horacio Quiroga, a Uruguayan-born writer who spent his adult life in Argentina, was a key figure in the development of film criticism, publishing extensively in journals such as Caras y caretas, Atlántida, and El Hogar from I9I8 to the end of the I920s. Unlike many of his contemporaries, Quiroga did not find cinema to be inferior to literature in its aesthetic qualities. Mediocre books are as plentiful as films, he pointed out, ${ }^{12}$ and he considered film to benefit from a narrative economy that is often lost in overwordy plays and novels. ${ }^{13}$ His writings on cinema consistently praise its realism over the 
exaggerated gestures, verbosity, and embellishments of theater. ${ }^{14}$ If his fellow intellectuals regarded cinema with animosity, he claimed, this was rooted in a class snobbishness that led them to dismiss it as "un simple espectáculo populachero" (a mere vulgar spectacle) rather than to appreciate its qualities as a form of dramatic art with poetic potential and psychological depth. ${ }^{15}$

Despite the impassioned defense of cinema Quiroga mounts in his critical and journalistic writings, however, it is generally the sinister side of new visual and imaging technologies that is explored in the short stories he wrote on the theme. "El espectro" (I92I), "El puritano" (I926), and "El vampiro" (I927) make incursions into the genres of science fiction and fantasy, dramatizing the capacity of visual technologies to blur the boundaries between life and death, presence and absence, and subject and object. In these narratives, the power of x-rays, photography, and the cinema stretches beyond that of recording life: these new techniques completely reorganize perception. If Arlt understood the potential of cinema to produce new forms of consumer desire, and perhaps even to provoke thoughts of social revolution, Quiroga finds in cinema a much more fundamental challenge to the categories that underpin our understanding and experience of subjectivity.

Edgar Morin notes, with respect to cinema: "Is it not astounding that the 'legendary,' 'surrealizing,' 'supernatural' quality should spring directly from the most objective image that can possibly be conceived of?" 16 Paradoxically, it is the intense realism of cinema that inspires Quiroga to write some of his most fantastical stories. Penning a critical note on D. W. Griffith's True Heart Susie (1919), he finds that the protagonists "corren por la eléctrica pantalla, tan vivas, tan del momento, que por poco que extendieran los labios o las manos, alcanzarían a tocarnos" (move across the electric screen, so alive, so in the present, that if they were just to extend their lips or hands, they would touch us). ${ }^{17}$ This notion is the stimulus for many of Quiroga's stories on cinema, in which actors and actresses leave the confines of the screen, invested with an agency that outstrips the simple mechanical capture and projection of their image. Quiroga plays with the fictional potential suggested by cinema's apparent granting of life beyond the grave to its actors, who continue to dazzle and dance across the screen even when their natural lives have come to an end. If the impression this causes in viewers who do not know the actors personally is already strong, Quiroga suspects that it must become a kind of "alucinación torturante" (tormenting hallucination) for those who know them well. ${ }^{18}$ This provides the nucleus of the plots of "El espectro," "El puritano," and "El vampiro," which weave a series of highly emotional entanglements between their pro- 
tagonists and the spectral images of lost loved ones on-screen, transgressing the boundaries between life and death.

The screen, therefore, is not a mere canvas onto which recorded images are projected. It becomes a threshold between life and death, past and present, fantasy and reality. The actors of "El puritano," now deceased, continue in a kind of somnambulant half-life in a cloakroom, disappearing for a short period when their films are screened again in Hollywood. They are caught in a contradiction, representing an "instant" but one that is also, at the same time, "imperecedero" (everlasting). The screen in "El espectro" is described as a "curtain" or a "corridor" through which the narrator and his lover, now dead, hope eventually to escape back to life. ${ }^{19}$ In "El vampiro," Rosales is encouraged by the devotion of cinema audiences to believe that "debe de haber allí más vida que la que simulan un haz de luces y una cortina metalizada" (there must be more life there than the kind simulated by a beam of light and a galvanized curtain). ${ }^{20}$ His experiments with $\mathrm{N}_{\mathrm{I}}$ rays ${ }^{21}$ succeed in animating the image of an actress, whose ghostly presence remains with him in his apartment even while her films are shown in Hollywood and whose soul seems to be transferred to her image upon her death.

It is this emphasis on cinema's power to conquer death that leads Beatriz Sarlo to identify Quiroga's stories as a cross between "mitología tardorromántica y tecnología sofisticada" (late-Romantic mythology and sophisticated technology). ${ }^{22}$ As Sarlo observes,

El invento por excelencia de la modernidad se convierte en condición de posibilidad de una imaginación narrativa exaltadamente romántica cuyo eje es el tópico de "un amor más allá de la muerte."23

The invention par excellence of modernity becomes the condition of possibility of an exaggeratedly Romantic narrative imagination, revolving around the topic of "love beyond death."

Quiroga delights in the incongruity that results from the conjunction of the Romantic with modern technology, repeatedly describing the apparatus of cinematography as cold or chemical, in contrast with the heat and turbulence of the emotions it arouses. Crucially, too, he insists that the cinematographic image may be animated, may cross into life, only through the emotions invested in it by both spectator and actor, whether of desire, fear, anger, or vengeance. If, as we are told in "El espectro," there are "leyes naturales, principios físicos que nos enseñan cuán fría magia es ésa de los 
espectros fotográficos danzando en la pantalla" (laws of nature, principles of physics that explain how cold the magic is that sets photographic ghosts dancing across the screen), ${ }^{24}$ these are insufficient to account for the forces of desire and destruction that transgress such laws.

In Sarlo's account of Quiroga's fiction, the ghosts and vampires of nineteenth-century literature breathe again by means of new technologies of the moving image. ${ }^{25}$ While she credits him with bringing a new interest in the material and the technological to lettered culture in the region, she finds that his is "una literatura que recicla tópicos del pasado" (a literature that recycles themes from the past). ${ }^{26}$ The question of what kind of innovation, if any, is effected or evoked by Quiroga's cinematographic fantasies is a significant one in the tracing of an imagined relationship between literature and new technologies of the image, the central theme of this chapter. On the one hand, then, there is a considerable continuity suggested with the themes and narrative modes of nineteenth-century literature, both in Quiroga's own stories and in the films that form a key element of their plots. Indeed, Pablo Rocca points out that Quiroga's discovery of cinema did not lead to the kind of radical experimentation with literary form that it did in the case of his Brazilian counterpart, João do Rio. ${ }^{27}$ On the other hand, I would argue, it did usher in a clear departure from realism. In particular, it inspired a reorientation of perception and perspective that begins to challenge the division between subject and object, a reorganization of the sensible that defines cinema for Quiroga and marks it as qualitatively new.

The cinematic apparatus in Quiroga's fiction allows for constant reversals in perspective. The screen does not erect a barrier between the viewing subject and the object of that viewing. It is a transparent membrane through which both actors and spectators may view the other, each the objects of the other's gaze; it is also a frontier across which desire and revenge are transacted, in both directions. The actors that characters watch on-screen (or create through their own projections) become invested with the power to act, often vengefully, on the watching subject. The resurrected Hollywood actress of "El vampiro" leaves her animator drained of his lifeblood, surrounded by fragments of burned film, while in "El espectro," the spectator, pointing his gun at the projection of his rival on the screen, somehow becomes the recipient of the gunshot himself.

Quiroga's stories attest to the power of cinema to reorganize perception and subjective experience, far beyond the simple recording or projection of images. That power is life changing; it is also ultimately devastating, even for those characters for whom it does not bring death. Cinema gives life, 
and it takes it away. The intensity and vibrancy of its images and stories cast everyday life into shadow, robbing reality of its vitality. "El vampiro" delivers a hyperbolic example of this operation: as soon as the film starts to roll, energized by light, electricity, and experimental Ni rays, "Toda ella se transforma en un vibrante trazo de vida, más vivo que la realidad fugitiva y que los más vivos recuerdos que guían hasta la muerte misma nuestra carrera terrenal" (It all transforms into a vibrating sketch of life, more alive than fleeting reality and the sharpest memories that guide our earthly journey to its death). ${ }^{28}$ As a technology for recording the transient, cinema delivers images that insert themselves into our sensory experience, becoming fully part of the material environment that presents itself to our senses. Indeed, they may seem even more lifelike, gaining a degree of vigor and consistency that outstrips that of our comparatively fleeting and vague impressions and memories. In the company of the reanimated actress, the narrator of "El vampiro" feels his real existence beginning to slip away. His daily life is nothing but "una alucinación" (a hallucination), and he is nothing but a ghost created to act a role: ${ }^{29}$ in the presence of cinema's heightened sensory and dramatic appeal, reality takes on the ephemerality of the spectral.

For Quiroga, then, cinema and photography provide new dramatic possibilities for literature's exploration of subjectivity. As the narrator comments in "El puritano,"

Nunca hasta hoy la literatura ha sacado todo el partido posible de la tremenda situación entablada cuando un esposo, un hijo, una madre, tornan a ver en la pantalla, palpitante de vida, al ser querido que perdieron. ${ }^{30}$

Never before now has literature taken full advantage of the terrible situation that arises when a husband, a son, a mother, turn to see onscreen, throbbing with life, the loved one they have lost.

Quiroga's fascination with the apparatus of cinematography also brings something new, as Sarlo suggests, to lettered culture of the region: "la cercanía efectiva con la materia y la herramienta" (an effective proximity to materials and tools). ${ }^{31}$ An emphasis on the material, the sensual, and the corporeal is omnipresent in these stories. In "El espectro," for example, the narrator reflects that he and Enid can still feel the brush of Duncan's hair as he emerges from the screen and moves toward them; mental impressions and emotions take on tangible form, just as anger and vengeance become 
alive in Duncan's "rastro químico" (chemical face). ${ }^{32}$ In myriad transmutations between human emotion, imaginary projection, and material inscription, Quiroga demonstrates the extent to which, as Morin suggests, "The cinema allows us to see the process of the penetration of man in the world and the inseparable process of the penetration of the world in man." ${ }^{33}$ The screen in Quiroga's stories is not a barrier separating representation from the represented world: it leads us to a greater understanding of the role of cinema and other visual technologies, in transporting us to a realm of the imaginary but also in immersing us in the material world.

The Magic of Machines: Anthropomorphic and Cosmomorphic Desire in La invención de Morel

As some critics have already noted, Bioy Casares's novel La invención de Morel (1940) revisits some of the principal themes of Quiroga's narratives on cinema, in its exploration of the ambiguous frontier between life and death, and the fatal attraction of the image. The novel has frequently been read as an exposition of the postmodern simulacrum, which erodes any distinction between reality and its simulation. ${ }^{34}$ Here, however, I will emphasize its contribution to the materialist current in Argentine science fiction. I read the novel in the light of Morin's theory of anthropomorphic projection and cosmomorphic identification, in order to tease out the relationship between the imaginary and the material in cinematic spectatorship. In La invención de Morel we also begin to see a more explicit alignment of literature with other technological regimes of representation, as the expression of a desire for transcendence and permanence beyond a human life-span, and to appreciate how such technologies shape our perception of time.

Watching scenes repeatedly played out before his eyes on the island on which he is stranded, Bioy Casares's narrator makes the startling discovery that it is peopled by hologram-like figures, captured and projected by a giant machine of Morel's invention. These extraordinary holograms are not simply three-dimensional projections in space; they also respond to the five senses, including touch and smell. Morel's machine was intended to improve on the work of a cinematographer, capturing its subjects through a complex system of radio waves and mirrors. The abhorrent design of the machine becomes apparent when the narrator realizes that, once captured on film, the original bodies die within days; their consciousnesses are transferred to their projected images, destined to repeat the events of a single 
week. For both Quiroga and Bioy Casares, it is desire that puts in motion the sinister mechanism that will lead to death: both a desire for immortality, and the voyeuristic desire for a woman. Morel admits that he invented the machine in order to perpetuate the dream of being with Faustine, with whom he is in love; for precisely the same reason, the narrator eventually takes the unconscionable decision to record himself and thereby enter Faustine's simulated world.

The central paradox here relates closely to Quiroga's: that while granting immortality, the recording and projection of the moving image simultaneously brings about death. Something of human life enters the image. In La invención de Morel, the narrator recalls the superstitious beliefs held by certain cultures about cameras, according to which capturing the image of a person causes the soul to pass into that image, and the person dies. Jean Baudrillard reflects in a similar manner on the "disquieting" nature of image reproduction, which involves "a kind of black magic":

Reproduction is diabolical in its very essence; it makes something fundamental vacillate. This has hardly changed for us: simulation ... is still and always the place of a gigantic enterprise of manipulation, of control and of death, just like the imitative object (primitive statuette, image of photo) always had as objective an operation of black magic. ${ }^{35}$

While the science of Morel's machine in Bioy Casares's novel is speculative-we know of no form of holographic projection that may respond to all five senses-it is, however, clearly presented as science, and not as black magic. Indeed, La invención de Morel is a crucial text in the genealogy of Argentine science fiction because it marks a clear affiliation with a materialist understanding of textual illusion, moving away from the idealist philosophical underpinnings of the greater part of fantastic narratives in Argentina and prefiguring the much greater dominance of materialist thought in more recent science fiction.

The difference may easily be grasped if we compare the novel with another text by Bioy Casares, the short story "En memoria de Paulina" (I948), in which the figure of Paulina reappears to the narrator in a fully embodied form after her death. He discovers that she is nothing but the projection of his rival's jealous fantasy, much in the same way as Borges's wizard dreams up every detail of a son in "Las ruinas circulares" and sends him out into the world. Both "En memoria de Paulina" and "Las ruinas circulares" playfully 
take to an extreme the tenets of philosophical idealism, according to which what we imagine takes form in the world around us, manifesting itself in the material realm, and the world is therefore an illusion. In La invención de Morel, however, Bioy Casares insists on the materiality of the machinery that generates the illusion of life or, more accurately, generates the form of existence that has come to replace what we understand as life. At the end of the novel, we are not left wondering_as we are with "Las ruinas circulares" whether our lives are merely dreamed up by another, but whether there is some infernal machine at work that manipulates our every movement, and whether our apparently free actions "dependen de botones que seres desconocidos pueden apretar" (depend on buttons pressed by unknown beings). ${ }^{36}$ The effect of both, of course, is to introduce a radical determinism. But while in the first, illusion is sustained by the life of the mind, in the second, the mind, the soul, and selfhood have all become an effect of the operation of mirrors, motors, and the energy generated by an island's tides.

For Quiroga, new technologies of image projection provide a source of new perceptions and dramatic scenarios for literature; for Bioy Casares, similarly, they add another dimension to the human drama of transience and the desire for immortality. However, Bioy Casares goes further to imagine a crucial continuity between literature and Morel's villainous invention. Rather than being repulsed by Morel's monstrous act, or moved to pity by his subjects' eternal imprisonment, the narrator ultimately feels envy for the kind of transcendence and permanence such repetitions seem to suggest, and which he finds lacking in his own life:

Acostumbrado a ver una vida que se repite, encuentro la mía irreparablemente casual. Los propósitos de enmienda son vanos: yo no tengo próxima vez, cada momento es único, distinto, y muchos se pierden en los descuidos. ${ }^{37}$

Accustomed to seeing a life that repeats itself, I find my own to be the irreparable product of chance. The idea of mending my ways is futile: I do not have a next time; each moment is unique, distinct, and many are lost from being overlooked.

The difference between the predetermined repetitions of the weeklong lives of the island's inhabitants, captured forever by Morel's machine, and the comparatively arbitrary and meaningless nature of the narrator's existence is heightened by Bioy Casares's recourse to the diary form in La invención de 
Morel. The diary conjures up the vagaries of daily experience: the contingent nature of events; misunderstandings that are later corrected; inconsistencies in behavior or motives; moods and desires that are at the mercy of changes in the weather. The narrator is thus immersed in the present, struggling to understand the wider meaning of a thousand daily mundanities and unable to construct the kind of broader, more coherent picture that hindsight might permit.

Wolfram Nitsch's perceptive analysis of the representation of writing in La invención de Morel finds that the old technology of the text is repeatedly set at a disadvantage in relation to the newer technology of Morel's machine. ${ }^{38}$ The power of literature appears to pale in the light of Morel's invention, and the narrator admits that "un hombre solitario no puede hacer máquinas ni fijar visiones, salvo en la forma trunca de escribirlas o dibujarlas" (a solitary man cannot construct machines or bind visions, except in an incomplete way to write them or draw them). ${ }^{39}$ As Nitsch observes, writing also fails in its task of seduction: the words of love laboriously formed out of flowers do not (cannot) attract Faustine's attention. When he reflects on his obsession with Faustine, the narrator notes "lo escribo para fijarle límites" (I write about it to set limits on it),,$^{40}$ but this endeavor also clearly fails, and Nitsch reads his eventual abandonment of the diary and his surrender to the machine as a recognition of its superior power. ${ }^{41}$ On the other hand, what restores writing to a position of partial transcendence for Nitsch is the fact that it provides Morel with the keys — set out in Morel's manuscript- to modify the machine, that in the form of the narrator's diary it is able to stage a reflexive return to reinterpret earlier observations with the greater accuracy of hindsight, and also, of course, that it survives as a testimony of what has taken place, communicating the truth of the island's machine to future readers. ${ }^{42}$

While Nitsch's discussion thus explores a conflict staged between "el viejo medio de la escritura" (the old medium of writing) and the fantastical new possibilities for reproduction and simulation evoked by Morel's machine, ${ }^{43}$ in what follows I emphasize instead the repeated parallels drawn in the novel between Morel's machine and the narrator's diary. These relate in greater part to the desire for transcendence and immortality encoded within them. When Morel is overheard saying to someone that all his actions and words have been recorded, for example, referring to the machine, the narrator mistakenly jumps to the conclusion that they have discovered his diary. Once he discovers that the machine's images may be subject to destruction, he declares that "mi propósito es salvarlas, con este informe" (my purpose is 
to save them, with this report), articulating a desire to rescue them from oblivion and render their memory immortal in much the same way as Morel's machine does. ${ }^{44}$ That his account does survive him and is somehow rescued from the island is made clear by the insertion of a fictional editor's footnotes. As the narrator hopes, "Estas líneas permanecerán invariables, a pesar de la flojedad de mis convicciones" (these lines will remain unchanging, in spite of the weakness of my convictions). ${ }^{45}$ It is suggested that the same desire for immortality that drives the construction of the machine also lies behind literature, in its attempts to bestow meaning upon life by lending it permanence and transcendence, eradicating the fleeting quality, the missed chances, and the senselessness of everyday existence. We look to the literary text, as to the cinematographic projections of Morel's machine, to rescue us from the vacillations and accidents of human time.

It can do no such thing, of course, and indeed the simulations of Morel's machine ultimately allow Bioy Casares to persuade us that the human is thoroughly embedded in a natural, material world, in relation to which it enjoys no position of transcendence. La invención de Morel invokes the power of cinematic projection to highlight the imaginary and material transactions that immerse humans within their environment. Humans, animals, and inanimate objects are caught up in exactly the same machinery of reproduction: Morel's machine captures and projects landscapes, plants, insects, books, walls, and humans, with indifference, and when the narrator records his own hand, he reflects that "ahora es como otro objeto o casi animal que hay en el museo" (now it is like another object or almost-animal in the museum). ${ }^{46}$ For Morin, cinema stages "the interchangeability of men and things, faces and objects," ${ }^{\prime 7}$ as film appears to energize and mobilize the material world alongside human actors. Morel's machine animates the world of things in a similar manner, as objects in the museum disappear and reappear in such a way that they seem to acquire a life of their own.

Bioy Casares's narrator clearly demonstrates the dual movements of "projection" and "identification" through which Morin finds the spectator to be caught up within the film, and which mirror the way we imagine our relationship with the world beyond ourselves. As Morin suggests, "Our needs, our aspirations, our desires, our obsessions, our fears, project themselves not only into the void as dreams and imaginings, but onto all things and all beings." ${ }^{48}$ Much of the novel's irony derives from the fear of persecution consistently projected by the narrator onto an entirely unconnected series of events: in every action he witnesses he finds allusions to his situation and the threat of conspiracy, suffering the delusion that everything he sees is 
"una máquina para capturarme" (a machine to capture me).$^{49}$ In the process of identification, which operates alongside projection, Morin claims that "the subject, instead of projecting himself into the world, absorbs the world into himself. Identification incorporates the environment into the self and integrates it affectively." ${ }^{\circ 0}$ This process can also clearly be seen at work in $\mathrm{La}$ invención de Morel, not least in the narrator's fateful affective identification with Faustine. For Morin, the dual processes of projection and identification correspond to forces of "anthropomorphism and cosmomorphism" that, respectively, "inject humanity into the external world and the external world into the inner man." ${ }^{51}$ The desire of Bioy Casares's narrator to enter the recording and realize his fantasy to gaze eternally upon Faustine, playing his part alongside her, is effectively a cosmomorphic desire to become integrated into a world of which he is merely a spectator.

For Morin, the cinematic apparatus binds the imaginary and the material in human experience. In films, he argues, "The fantastic transformation and the material transformation of nature and man intersect and replace one another. Dream and tool meet and fertilize one another." And again, "The imaginary and the technical rely on one another, help one another. They always meet not only as negatives of each other but as mutual fermenting agents." ${ }^{2}$ La invención de Morel stages this "dialectical unity," ${ }^{33}$ demonstrating not only the mutual penetration of human subject and world but also the simultaneously imaginary and material qualities of the cinematic image. Crucially, though, it also finds the literary text to be an expression of the same anthropomorphic and cosmomorphic desires, the same projections and affective identifications, through which we seek to incorporate and integrate ourselves within the material environment and thereby, paradoxically perhaps, to secure for ourselves a coherence and a transcendence we are otherwise denied.

\section{El juego de los mundos: From Prosthesis to Plasticity}

If literature in La invención de Morel becomes an expression of our (often fatal) desire for immortality, in Aira's El juego de los mundos (2000) the immortality now enjoyed by the citizens of an imagined futuristic society has rendered literature a useless and anachronistic artifact. The disappearance of books as we know them, eclipsed by forms of visual and virtual media, brings radical changes to modes of perception, thought, and social relations. However, this does not provide a cause for simple lament. In Aira's often 
ironic fable, literary culture is rarely held up as the fount and pinnacle of human civilization: indeed, we find, it was the narcissism and vanity of writers that ultimately brought about the demise of literature. Neither does Aira uniformly denounce the new visual regimes that have supplanted literature as narcotizing agents of consumerism. He holds no truck with more reactionary assertions that pit literature against the passive consumption of images, and explores the idea that-from a philosophical point of viewliterature has, logically, few roles to play in a Leibnizian best of all possible worlds in which man has now discovered the long-elusive secret of immortality. Aira's searching enquiry into what might be lost, gained, or sustained in the replacement of words with images, and the wider transition from literary culture to virtual systems of intelligence, reveals an interest in the shared prosthetic nature of books and images, as well as in the plasticity of human intelligence. It thereby advances a materialist understanding of the operations of mind and language, which are extensively shaped by technical supports and specific environmental conditions.

Set in the far future, Aira's novel describes an era in which the "worlds game" has become the most popular way of passing time. The game is played using the Total Reality system and consists of traveling to another world inhabited by an intelligent species, declaring war, and annihilating them. Lest we assume that this is some new advance in virtual reality, it is clearly explained to us that these worlds are as real as our own. Success in the "game" is guaranteed, however, given the superiority of this world's weapons and tactics. El juego de los mundos is narrated from the viewpoint of a member of the older generation, who views with suspicion the "game" his son plays with such gusto. He finds it deplorable that his "civilized" world should treat other worlds as disposable in this manner, placing them at the mercy of the entertainment industry. His son, an active player of the "game," argues in response that it is only players such as he who take other worlds seriously, studying their features carefully, while those who do not play the game have no interest in other worlds whatsoever. It is the conflict between the perspectives of father and son that allows Aira to develop a sustained and intriguing comparison of the differing roles of literary and visual culture within society and the evolution of human thought.

Literature as we know it no longer exists in the world of El juego de los mundos. In the distant past, all texts were transcribed by an automated system into images: word by word, or often even syllable by syllable. The result is a flow of rebus-like images that strips words of their original meaning. Thus the beginning of the phrase "un día, de madrugada" (one day, in the 
early morning) might be rendered with an image of a vertical index finger, followed by an astronomical figure to express "day"; alternatively, the system might combine "día" with "de ma-" (diadem) and insert a crown of dazzling diamonds. ${ }^{54}$ The arbitrary way in which syllables are divided up, together with the use of images to transcribe literal meaning, results in a string of images from which the original meaning of the text cannot possibly be deciphered. We are told that the transition from the era of print culture to that of the image was effected in a single step, with the instant destruction of the original books, leaving only these enormous and enigmatic image-strings. This act of transcribing literature has eradicated differences between works and authors: the transcriptions flatten out style and all variation in language, dialect, or register. "Reading" has been reduced to watching these images as they pass before one's eyes, at a rate of at least ten images per second. Not surprisingly, it has become almost entirely obsolete as a practice. The narrator is unusual in choosing to dedicate at least an hour or two every day to what has become, in the eyes of the majority, an antiquated exercise.

Does this translation of literature into images represent an impoverishment of the act of "reading"? Aira is characteristically ambivalent on this score. The narrator reflects that literature has been reduced to "cadenas incoherentes de imágenes" (incoherent chains of images) ${ }^{55}$ and "un vértigo de rebus insensatos" (a dizzying string of senseless rebuses). ${ }^{56}$ On the other hand, he is told that he has misunderstood the very essence of the literary, which consists in the invention of new stories from a given sequence of images, which would then in turn be translated into images and give rise to ever more stories, and so on, in an endless deferral of meaning. Aira certainly avoids descending into a diatribe against the passivity of mass culture consumption of the kind that one would find in Adorno or Baudrillard. If the translated strings of images are a mere shadow of print culture, he presents the "worlds game" as a more worthy successor. Indeed, the narrator's son considers "reading" to be "pasivo, sin compromiso, sin vida . . . sin emoción" (passive, without commitment, lifeless ... emotionless) ${ }^{57}$ in comparison with the "worlds game," which requires an active curiosity on the part of the player, an engagement with the real world, and (theoretically, at least) a willingness to take risks. If literature was, in times past, a route into knowledge of worlds beyond our own, rescuing us from insularity or ignorance, it is clear that this function has been taken on by the "worlds game." Such knowledge is hardly innocent, of course: it clearly goes hand in hand with the destruction and domination of other worlds.

In Bradbury's Fahrenheit 45I, discussed above, Montag fears that the 
burning of books will wipe out messages they might contain that would help to save society from repeating its mistakes and destroying itself. In Aira's best of all possible worlds, there are no longer any problems to solve. It is not the ascendancy of mass society, consumerism, the image or virtual reality that has put paid to the traditional form of literature, but the discovery of immortality. This, the narrator considers, completely devalues literature. The story once took its place as the account of a survivor of an adventure, but if everyone always survives, wherein lies the value of a survivor's tale? As a result, "Ya no sucedían aventuras, no se improvisaba, no había espontaneidad" (There were no adventures any more, no one improvised, there was no spontaneity), ${ }^{58}$ and as the adventure and its story are two sides of the same coin, both have been eclipsed.

In suggesting that literature has no viable role to play in an infinite world of immortals, Aira draws on some recognizably Borgesian conceits. In Borges's "El inmortal," man's knowledge of his immortality dissolves all individuality, ethics, and creativity: the city of immortals is inhabited by troglodytes who can barely rouse themselves to stammer a few words. The Leibnizian best of all possible worlds, Aira decides, could not possibly contain literature. Literature arises out of man's loneliness and his struggle with forces beyond his grasp. As the narrator states, "En el ser humano, la soledad nació con la captación de lo universal" (In human beings, loneliness is born with the apprehension of the universal). ${ }^{59}$ The literary is fully associated with the new in experience, a concept that is logically impossible in a world of immortals: as Borges explained, the only impossibility is for an individual not to compose the Odyssey, at least once, in his lifetime.

The narrator of El juego de los mundos sets out in search of the unique and - in one of Aira's most ludic passages - manages to discover God, hidden somewhere in the system. Surprised to find that the deity is about forty centimeters tall and made of cardboard, with a spider's legs and a blond wig, the narrator becomes embroiled in an unholy scuffle with Him, grabbing His wig to play football with it, and running across the galaxies with the Supreme Being in hot pursuit. While recognizing that the turn of events has necessarily become somewhat "extravagant" and even "ridiculous," the narrator succeeds in disrupting the wearisome predictability of his world with a unique event, and now has a story to tell. ${ }^{60}$ The passage can be read as a metafictional, tongue-in-cheek defense of Aira's own predilection for exploiting the utterly fantastical as a means of throwing conventional modes of realism into disarray. It is, nevertheless, wholly in keeping with one of the novel's overarching themes, the relationship of literature with newness. 
In other respects, however, Aira prefers to focus on the continuities between traditional literature and the visual and virtual systems of information and communication that he presents as having superseded it, in a way that demonstrates their common status as prostheses in human thought and social relations. In El juego de los mundos, meeting face-to-face, without the means of telepresence, has become unusual and rather old-fashioned; instead, most encounters between people and worlds take place within the "Realidad Total" (Total Reality) system. This system, somewhat akin to the matrix of Gibson's Neuromancer (1984), allows for the storage and retrieval of all known facts about the universe. Most people use a "Rectificador de discurso" (Speech Corrector) to help them communicate with others: this is a technology that improves the flow and efficiency of speech, editing it in real time. The narrator observes that these devices automatically adapt to the personality of the speaker. By creating a sense of authorial style in this way, "Coincidían, por casualidad, con la vieja práctica de la literatura" (They just so happened to coincide with the old practice of literature). ${ }^{61}$

Other vestiges of literary modes of representation are also detectable in the $\mathrm{RD}$ system. At one point, a friend regales the narrator with an anecdote, telling him about an occasion on which he demonstrated unusual perceptiveness. The narrator is thrown to discover that the character and the event of the anecdote have been invented by his friend: it is not a real story, but an "example." The narrator struggles to understand the meaning of "example," a new word for him. He is told that it is a particular case that has the characteristics of all the different cases of its kind, but he still doesn't understand the concept: “¿Cómo puede ser un caso particular no real?" (How can a particular case not be real?). ${ }^{62} \mathrm{He}$ is particularly bemused by the detail with which the friend had related his story, even going as far as to mention the way his invented character puts his hands in his pockets when he is puzzled. It is explained to him that this is "una verosimilización" (a technique to enhance verisimilitude). ${ }^{63}$ The RD system, which contains an "ejemplificador" (exemplifier), acts in many ways as an analogy for the workings of (realist) literature, which narrates a particular case that is representative of its type but is not real, and which embellishes its story with details with the aim of increasing verisimilitude.

The analogies drawn throughout El juego de los mundos encourage us to see the relationship between traditional literature and the novel's futuristic systems of information and communication as essentially one of continuity rather than rupture. Literature's operations have not been superseded so much as displaced onto other forms of media and virtual reality. This allows 
us to perceive the properties they share as technologies of prosthesis. All prosthetic technologies organize perception and subjectivity in particular ways, and the difference between these becomes Aira's principal interest in the novel.

El juego de los mundos makes continual references to certain categories according to which rational thought is organized, such as the particular and the general, the partial and the total, the relative and the absolute. Just as the narrator cannot understand the concept of an invented example-a case that is not a true case but has all the characteristics of one-so other characters have difficulty thinking in abstract or universal terms beyond the concrete nature of particularities, or in linking theory with practice. The narrator, miserably out of sync with this new, textless society, complains that his son's generation has grown accustomed to thinking in "concrete terms," and that only his son is still able to translate these occasionally into "la universalidad en que se movía mi mente" (the universality that my mind moved in). ${ }^{64}$ It is clear that this difficulty in translating between the universal and the particular, and the abstract and the concrete, has come as a result of the decline of textuality. The narrator reflects that the reduction of texts to meaningless strings of images has limited generalizing thought, as "Las singularidades lo habían invadido todo" (Singularities had invaded everything). ${ }^{65}$

Rather than deploring the decline of literature and textuality, however, Aira shows much greater interest in using the shift from reading to playing the "worlds game" to explore the plasticity of human intelligence, which is continually shaped in different ways by the particular tools and prostheses it uses to extend its perceptions and abilities and interact with a changing environment. In this way, El juego de los mundos echoes the insights of a number of theorists of cyborg identities, including Andy Clark, for whom the essence of human intelligence is precisely its ability "to enter into deep and complex relationships with nonbiological constructs, props, and aids."66 Clark argues that different kinds of "human-machine symbiosis" expand and alter psychological processes at a fundamental level, whether these are new experiments with virtual reality or "old technologies of pen and paper." 67 In consonance with other philosophers of the science of human evolution, including Sterelny and Stiegler, Clark emphasizes crucial aspects of brain development that are not genetically determined but shaped by individual experience. As Sterelny suggests,

If our minds are (mostly) ensembles of (largely) prewired modules, then human nature is largely the same everywhere and when. But 
we are pervasively and profoundly phenotypically plastic: our minds develop differently in different environments. ${ }^{68}$

El juego de los mundos clearly shows us how the human mind responds to changing environments and different kinds of technological prosthesis, which enable certain modes of thought while disabling others. This understanding traverses many of Aira's novels, including La guerra de los gimnasios (1992), La villa (200I), and Embalse (1992), in which televised images merge almost imperceptibly with characters' perceptions of real landscapes, projected continually even in the absence of a television set.

In What Should We Do with Our Brain?, a work that mediates between philosophy and contemporary neuroscience, Catherine Malabou discovers an uncanny similarity between new models of how the brain works developed in neuroscience and the dominant model of capitalism as a dynamic, decentered, and highly adaptable system, in which flexibility and participation in multiple networks is demanded of the worker who wishes to succeed. If a previous understanding of how the brain works typically traced a series of hierarchical relationships, in which the brain was pictured as the central or controlling organ, the new neuronal paradigm emphasizes "a plurality of mobile and atomistic centers, deployed according to a connectionist model." ${ }^{69}$ As Malabou argues:

In the same way that neuronal connections are supple and do not obey a centralized or even truly hierarchized system, political and economic power displays an organizational suppleness in which the center also appears to have disappeared. The biological and the social mirror in each other this new figure of command..$^{70}$

Aira’s El juego de los mundos depicts a similar mirroring between the processes of human thought and the broader operations of power, raising exactly this question of how a particular "figure of command" might come to govern a whole society. If Malabou fears that the new understanding of the brain acts to naturalize the dominant socioeconomic system of our time, neoliberal capitalism, the danger Aira dramatizes in his novel is that the changes in human thought processes that result from the "worlds game" may reintroduce a much more hierarchical structure of authority in a world that currently benefits from the moral and philosophical freedom of liberalism.

What the narrator is able to grasp-and the younger generation cannot - is that the popularity of the "worlds game" is effectively preparing the 
minds of the younger generation for the reintroduction of the idea of God. In the novel, it is explained that God had (unwittingly) been destroyed by the narcissism of writers such as Aira, whose desperation to discover what place their work might have in the new order produced an overload of the system, which subsequently short-circuited. The narrator, anxious to protect the liberalism of the new era, is horrified by the prospect of the return of God and fears that the idea of God is implicit in the worlds game. He reasons that

los mundos, por ser reales, son particularidades que ocupan cada vez el campo entero de la realidad, y no dejan espacio más para un ser ultraparticular, una generalidad singular, que sería justamente la vieja y archipodrida idea de Dios. ${ }^{71}$

the worlds, because they are real, are particularities, each of which occupies the entire field of reality, and only allows space for an ultraparticular being, a singular generality, which would be precisely the old and totally noxious idea of God.

If the fates of the worlds, representing "partial totalities" within the system of the universe, are subject to a throw of the dice, this opens up a path that might lead back to theology, allowing for the possibility of a supreme being, a "singular generality," who might decide those fates. The narrator is forced to acknowledge that the idea of God is embedded within his antecedent Aira's work. "Al parecer mi antepasado escritor había puesto las bases para una superación del saber a partir de las singularidades de la literatura" (It appears that my writer-predecessor had laid the ground for an improvement in knowledge on the basis of literature's singularities), ${ }^{72}$ he realizes, in a probable self-reference to Aira's construction of his novels as singularities that are gathered together to form a kind of encyclopedia. ${ }^{73}$ The existence of plural worlds (or texts), and the contact between them, points back to God, or a higher system of knowledge that embraces these worlds and the relationship between them (the Creator-Writer). The narrator fears that his world is about to be led, unknowingly, back to the subjugation of life under a divine authority.

In the context of the parallels she observes between recent neuroscientific paradigms and the dominance of certain structures of command in society, Malabou reasserts the resistance that may be offered by the brain's plasticity. Crucially, the brain is not merely flexible and impressionable, but "plastic" 
in the full sense she describes. She reminds us that the word "plasticity"which comes from the Greek plassein, to mold-has two senses: first, "the capacity to receive form," like clay, and second, "the capacity to give form," as in the plastic arts, or plastic surgery. If the brain is "plastic," it is because it both receives form and is formative. ${ }^{74}$ In many ways, Aira’s El juego de los mundos reflects on an ethical question that becomes central to Malabou's work: how should we then use our brain? By becoming more conscious of the plasticity of those mechanisms that form our sense of self, Malabou suggests, we may acquire the ability to give form to the world around us rather than simply submit to the influences of our environment:

To ask "What should we do with our brain?" is above all to visualize the possibility of saying no to an afflicting economic, political and mediatic culture that celebrates only the triumph of flexibility, blessing obedient individuals who have no greater merit than that of knowing how to bow their heads with a smile. ${ }^{75}$

Becoming aware of the kind of transformations our brains undergo potentially enables us to create resistance to certain systems rather than simply adapting flexibly to them. This is also the premise of El juego de los mundos, whose narrator gains an insight into the relationship between thought patterns and the broader mechanisms of societal control and is therefore able to act to challenge the threat of a resurgent God.

With characteristic irony, Aira presents literature as both the source of the problem and its potential overcoming. El juego de los mundos presents Aira's own narcissism as the possible cause of the destruction of literature and, it is feared, the return of an oppressive supreme being. And he has certainly not learned his lesson: the novel is full of precisely the same reflexive and intertextual references that lead us straight back to himself and his work. The narrator adopts the "sonrisa seria" (serious smile), a repeated reference in Aira's novels, as facial gesture of his own. ${ }^{76}$ As José Mariano García points out, the example the narrator chooses to demonstrate how literary texts were translated into images is not, as he claims, "una frase cualquiera" (a random phrase) $)^{77}$ but the first phrase of Moreira (1975), the first of Aira's novels to be published. ${ }^{78}$ For such reasons, García suggests that we read El juego de los mundos as "una especie de metáfora de su escritura" (a kind of metaphor for his writing). ${ }^{79}$ Importantly, however, it is the narrator's familiarity with the phenomenon of literature in its traditional printed form, now extinct, that makes him the only one able to grasp the impending disaster awaiting a 
society that complacently assumes it has done away with its divine dictator. Literary culture, like new technologies of the image or new forms of virtual experience, produces unique transformations of processes of human thought and perception. Aira's novel never laments the passing of literature as we know it, but points to the importance, both epistemological and ethical, of gaining insight into those transformations as a means of shaping our own destiny.

\section{Conclusion: Plasticity and the "Dusk of Writing"}

The screens, projections, and enhanced cinematographic technologies that are ubiquitous in science fiction novels, from the multisensory "feelies" of Aldous Huxley's Brave New World (1932) to the bidirectional telescreens of George Orwell's 1984 (1949), have presented insidious new forms of social control as well as a threat to traditional cultural values. Science fiction has typically fallen into step with many of the twentieth century's most prominent theorists in their ardent indictments of the increasing incursions of a mass culture organized around images. In Adorno's critique of the culture industry, a formulaic cinema prescribes behaviors and attitudes for the passive consumer; the primary role of the "dream industry" is to indoctrinate the spectator, perpetuating the socioeconomic hierarchies of society. ${ }^{80} \mathrm{Bau}-$ drillard constructs a similarly negative scenario, assigning cinema to the domain of the hyperreal, in a world of simulations and simulacra in which the image has lost any connection with reality. ${ }^{81}$

The texts discussed in this chapter tell a different story. While they often narrate the partial or total eclipse of literature in the face of powerful new visual modes of drama, they do not find in this a simple cause for regret. Rather than depicting new modes of (audio)visual communication and entertainment as forms of pacification and vehicles for bourgeois capitalist ideology, as both the Frankfurt School and more recent theorists of the postmodern have tended to do, Quiroga, Bioy Casares, and Aira have imagined the relationship between literature and new technologies of the image in different, and rather more creative, ways. All three writers certainly attest to the sinister potential of such technologies to entrap individuals in fantasies and obsessions to the extent that they often become blind, or indifferent, to their own self-destruction. Quiroga's cinephiles, driven to meddle with the forces of life and death by the intensity and vibrancy of cinema's illusions, become the victims of vampirism or other forces beyond the grave. The narrator of 
Bioy Casares's La invención de Morel is so deeply entranced by the projected image of a woman that he willingly gives up his life to enter a world of fantasy. The young players of Aira's El juego de los mundos become so absorbed in the pursuit of other worlds that they are oblivious to the philosophical and social consequences of the game for their own.

However, these writers primarily seek to incorporate the visual or virtual technologies they imagine within the literary tradition, or to understand in a broader sense the profound shifts in subjectivity and even socioeconomic systems that may result from the dominance of different media technologies. A rhetorical appropriation of the image belongs to a rich tradition within Argentine and Latin American literature, and one that is deftly traced by Valeria de los Ríos in Espectros de luz: Tecnologías visuales en la literatura latinoamericana. In the work of writers as diverse as Lugones, Quiroga, Arlt, Cabrera Infante, Cortázar, and Bolaño, De los Ríos finds that "la escritura se convierte en un espacio que integra la influencia de los nuevos medios" (writing is transformed into a space that incorporates the influence of new forms of media) presenting itself as "un lugar privilegiado para analizar la impronta de la visualidad en la cultura" (a privileged site for analyzing how visuality has made a mark on culture) ${ }^{82}$

In a similar way, the texts I have discussed here ironically resort to literature to narrate the eclipse of that particular textual technology: not as a motive for protest or nostalgia, but as a way to approach broader questions concerning the interplay between subjectivity and different regimes of communication or expression, or how human thought is shaped by the technologies it has brought into being. In this manner, their fiction can be brought into dialogue with Malabou's argument concerning the elevation of "plasticity" as the most productive paradigm for our time, marking the decline of writing, which has hitherto held that position of dominance.

Malabou draws on Derrida's Of Grammatology in her account of how writing came to constitute itself as the prevailing "motor scheme," in a movement that begins with structuralism and is grounded in linguistics, genetics, and cybernetics. ${ }^{83}$ Derrida finds the notion of writing to embrace concepts of trace, inscription, code, and program, all of which became organizing principles in accounts of cell biology and the theory of cybernetics. ${ }^{84}$ Malabou contends, however, that "we must acknowledge that the power of the linguistic-graphic scheme is diminishing and that it has entered a twilight for some time already." In its place, "Plasticity is slowly but surely establishing itself as the paradigmatic figure of organization in general." 85 This gradual revolution accompanies a growing understanding of the limits 
of genetic determination and the importance of neuronal plasticity, or in other words the ability of the brain to modify itself as a result of experience. Neuronal traces do not proceed as writing traces do, argues Malabou: they do not leave a trace, but take place as a change in form, ${ }^{86}$ such that "we can therefore make the claim that plasticity forms where DNA no longer writes." ${ }^{87}$

Aira's novel, in particular, is concerned with such shifts in conceptual understanding that might attend the decline of writing, not just in the form of literary culture, but as a paradigm with much broader power in the organization of philosophical beliefs and social relations. It is in his novel that the notion of plasticity is most thoroughly explored, in a way that casts into shadow the rise or fall of any one cultural form of expression. But the fictions of Quiroga and Bioy Casares discussed here also provide important intimations of the emergence of plasticity as a paradigm, highly attentive as they are to ways in which imagined technologies may open up new forms of being, and to how subjectivity may be profoundly shaped by a complex and shifting relationship with new representational regimes. If, as Ian James observes, Malabou's claim relating to the coincidence of neuronal function and sociopolitical organization is "perhaps rather speculative, but certainly provocative," 88 for that reason it provides highly fertile ground for literary exploration. Paradoxically, literature emerges as a privileged locus for discussions of its own decline, drawing on its others-photography, cinematography, mass culture, even new paradigms of plasticity—in order to extend and diversify its own praxis. 


\section{5 / Beyond the Linguistic Turn \\ Mathematics and New Materialism in \\ Contemporary Literature and Theater}

In the conclusion to the last chapter, I suggested —-with reference to the work of Catherine Malabou - that science fiction texts by Quiroga, Bioy Casares, and Aira may point toward a decline of the regime of writing and the rise of an alternative organizational paradigm, that of plasticity. For Malabou, graphic-linguistic models of inscription, programming, and coding, which are reliant on images of "gap or difference," provided powerful interpretative tools that were key to the dominance of structuralist, poststructuralist, and deconstructive approaches. ${ }^{1}$ The paradigm of writing is now, she suggests, being replaced by plasticity, which "characterizes a regime of systematic selforganization that is based on the ability of an organism to integrate the modifications that it experiences and to modify them in return."2 Ian James observes that Malabou's commitment to plasticity is "first and foremost a commitment to a radical materialism,"3 and this is certainly evident in Malabou's emphasis on processes of transformation and on complex exchanges between human experience and the environment.

In this chapter I explore a number of contemporary science fiction texts that register a move away from the linguistic paradigm and toward one that may best be described as "new materialist." As a body of thought associated with the work of Manuel De Landa, Rosi Braidotti, and Donna Haraway, among others, new materialism is a critical response to the dom- 
inance of the "linguistic turn" and social constructivism under structuralism. Instead of understanding language as constitutive of reality, new materialism emphasizes, as Braidotti puts it, "the concrete yet complex materiality of bodies immersed in social relations of power." ${ }^{\text {"4 }}$ It attempts to rethink the dualisms (mind/body, nature/culture, human/inhuman, language/reality) that have remained intact in postmodern thought, and to give greater attention to what has been neglected in postmodernism, principally matter and the processes of material transformation. ${ }^{5}$ This does not imply a naive rejection of the role of cultural mediation: as Diana Coole and Samantha Frost put it, "Our material lives are always culturally mediated, but they are not only cultural." "They are also embedded in, and formed by, complex exchanges between the organic and the inorganic, in which the material world is not a passive partner.

As scriptwriters, directors, translators, and theorists, Javier Daulte and Rafael Spregelburd (who is, in addition, an actor) are prime examples of the "teatrista," a term that has become popular in porteño theater circles in recent years to encompass multiple roles within the creation, staging, and critique of theater. They are part of a new generation of dramatists who have experimented with different modes of theatricality since the mid-199os, seeking to challenge the predominance of text and discourse in theater by exploring extralinguistic and nonsymbolic forms of meaning. In the wake of the Teatro Abierto movement, which began in 198I as a cultural response to the dictatorship, much Argentine drama has pursued realist approaches with respect to national history and contemporary politics. The work of Spregelburd in particular exemplifies a recent interest in Argentine theater in positing realms of experience that cannot be reduced to the linguistic, and in constructing a postanthropocentric vision in which the agency of the material world is brought to the fore. While many of his dramatic pieces borrow elements from science fiction, La paranoia (2008) is his most explicit engagement with the genre, and also one of his most sustained metafictional excursions. The first part of this chapter contrasts La paranoia with Javier Daulte's $4 D$ Óptico (2003) in order to set into relief Spregelburd's turn away from a linguistic, constructivist paradigm and toward a new materialist one. The second part presents a reading of two novels by Marcelo Cohen, Variedades (1998) and Donde yo no estaba (2006), which develop a new materialist understanding of subjectivity and also move on to explore how we might conceive the role of literature and writing differently within a materialist paradigm. 
The Mathematics of the Material Universe: The Science Fiction Theater of Javier Daulte and Rafael Spregelburd

A team of laboratory scientists in the employ of a huge Japanese company is at work on a new version of the Hyperdeep, a high-tech optical device designed to detect ever-decreasing stocks of fish in the ocean. An accident during testing has the effect of creating a portal to an alternative world. With the help of a software program that unfolds the folds of Einsteinian spacetime, the scientists detect a parallel plot taking place in a mansion elsewhere. There, a singer is about to perform her last concert before being assassinated. The conspirators' passions and rivalries mirror those of the scientists back in the first world, who realize that they must derail the assassination plot if the collision of the two alternative realities is not to produce an implosion of the universe.

In Javier Daulte's comedy $4 \mathrm{D}$ Optico, ${ }^{7}$ science does not serve the disinterested pursuit of knowledge. It is entirely funded by businesses seeking a greater competitive edge: North American insurance companies have invested millions in predictive technologies to minimize their losses, while the tourism sector funds research into chaos theory in the hope of more accurate weather forecasts. However, Daulte's conception of theater as a game, committed only to the rules of that game and opposed to a "teatro responsable y tal vez didáctico, o en definitiva, por qué no, dictatorial" (theater that is responsible and likely to be didactic, or ultimately—why not? — dictatorial) leaves little room for solemn social comment on the dubious operations of scientific or commercial institutions. ${ }^{8}$ His use of science in $4 D$ Optico is primarily placed at the service of developing a metatheatrical approach, and the science fiction genre is thoroughly parodied. The scientists are not interested in saving the world so much as seeking personal fame by publishing their alternative-reality hypothesis and pursuing their various amorous adventures. Moreover, while the play draws on real science, such as the curvature of space-time and heterotic string theory, its characters' explanations swing between deliberately opaque scientific mumbo-jumbo and oversimplifying, banal images, such as a "flexible banana," used to describe folds in space-time. ${ }^{9}$

More broadly, the parallel-universes plot allows Daulte to expose the devices and illusions of theater. Our attention is drawn to the play's extremely deft choreography, which takes us seamlessly from one world to the other, and charts the increasing transgression of objects and people across the 
threshold that supposedly separates them. The fact that the actors playing the scientists in the laboratory are the same as those playing the gangsters in the mansion highlights the practice of doubling up in casting: it is only later that we realize that this is not the usual convention of reducing cast members to a more manageable number, but a crucial element of the play's poetics. As María Florencia Heredia observes in her study of the play, metatheatricality is also developed through scenes such as the one in which the scientist Paulina, in an effort to thwart the assassination plot, consciously takes on the role of Angie in the mansion and is manipulated by another of the scientists with a kind of joystick. ${ }^{10}$ A metatheatrical intent also lies, of course, behind the scientists' discovering that what they experience as reality is only an illusion, as their experiments prove that "el mundo material no existe" (the material world does not exist). ${ }^{11}$

Daulte's flirtations with science fiction draw closely on the River Plate tradition of fantastic literature. The mannequins in his Automáticos (2005) ${ }^{12}$ gradually take on human gestures and emotions, recalling the increasingly lifelike dolls of Felisberto Hernández's Las Hortensias (1949), while the inclusion of Borges's poem "El Golem" (from El otro, el mismo, 1964) in the text of ${ }_{4} D$ Óptico clearly acknowledges the influence of Borges's fictional forays into philosophical idealism. Rafael Spregelburd's La paranoia (2008), the principal focus of the discussion that follows, also appears to emerge from this tradition: Spregelburd himself ventures a comparison with Julio Cortázar's "La noche boca arriba," in which the relationship between the real world and a dream world is suddenly inverted at the end of the story. ${ }^{13}$

Both Daulte and Spregelburd find in mathematics a commitment to observing and developing forms, systems, and procedures that provides an ideal model for a theater that wishes to question the prevalent mode of social realism. Daulte explains that, as a system of relations, mathematics is "indiferente a los contenidos" (indifferent to content); its rules are arbitrary in the sense that they are not allegorical of something else, and they are a rich source of narrative possibilities when combined with other rules to form what Daulte calls a "procedimiento" (procedure). ${ }^{14}$ Spregelburd also draws on mathematics and science-fractals, Gödel's theorems of incompleteness, chaos theory-in his search for new forms and systems that suggest the complexity of the universe, beyond its possible constructions in human language.

A crucial difference emerges between Spregelburd and Daulte, however, in the appeal they make to mathematical and scientific models in their work. Daulte-as we have seen in the case of $4 D$ Optico—often points to the impact of the subjective (emotions and human relationships) on the supposedly 
objective (scientific advances), and draws on Einsteinian physics to suggest the ultimate unreality of the material world. Spregelburd, on the other hand, turns to mathematics and scientific theories to explore a realm of reality that exists beyond the human: a materiality that subtends the universe and resists our attempts to reduce its complexity. It is not mathematics as an abstract, content-free series of forms that motivates his work, but the glimpse it affords us of a complex patterning that traverses the physical world and links all phenomena in dynamic and aleatory associations.

Spregelburd's La paranoia is set in the distant future, when time is measured according to the Mayan calendar, and humanoid robots and teletransporters are old technology. The universe is governed by the "Intelligences," supreme beings that maintain the cosmos in a state of equilibrium and have guaranteed peace for the world. There is, however, a condition placed on their protection: that humans continue to supply them with a raw material for which they have an insatiable need, and which is unobtainable on any other planet. Their desire is for fiction, humanity being, it seems, "la única especie capaz de imaginar lo que no pasa" (the only species capable of imagining what doesn't happen). ${ }^{15}$ The Intelligences first ransacked the world for its books, and then proceeded (with decreasing levels of satisfaction) to plunder its films, television programs, documentaries, cartoons, and reality shows. Then, fortuitously, they were transfixed for 253 seasons by a small artificial plant, before even that eventually lost its appeal.

Such is the crisis that brings together three specialists in Piriápolis, charged with the task of inventing an original fiction that will please the Intelligences and ensure the survival of the planet. They comprise a mathematician who has trouble with natural numbers, an astronaut who "doesn't practice," having been psychologically scarred by a traumatic encounter with gamma rays, and a writer whose plagiarists are more successful than she is. They are assisted by an obsolete model of a robot who refuses to countenance the idea that she is not human. The action of La paranoia is split between the stage and a large screen placed toward the back of the stage, on which we view sequences that appear to belong to a number of different fictional narratives, including a speech given by a (probably Lithuanian) submarine captain to his crew members, an exchange between two Japanese soldiers after the invasion of China, a transvestite performance in a Venezuelan cabaret, and the tragic story of Brenda, a young girl chosen by a powerful corporation to undergo intensive training and plastic surgery with the aim of turning her into Miss Venezuela, and eventually Miss World.

As spectators, our initial hypothesis is that at least some of these filmed 
sequences represent fictions invented by the Piriápolis team: it is they who come up with the Brenda story, and an investigation into the case provides the motor for the comically clichéd scenes from the Venezuelan crime drama. Moreover, the scenes often appear to respond to the twists and turns of the onstage narrative, as the team tries desperately to comply with the impossible rules issued by the Intelligences concerning the kind of fiction they require. The rules are as follows. First, as the Intelligences think as one, they cannot accept the development of individual characters. Second, they will not accept what they refer to as "estilo" (style), being the creation of similarities between one thing and another. ${ }^{16}$ Third, they reject hierarchies: "Odian la división racional en figura y fondo" (They hate the rational division between figure and background). ${ }^{17}$ The narrative must not direct the perception toward a single person or event, casting the others into the background, but allow for greater freedom and diversity of perceptions. In fourth place, the fiction must not attempt to activate processes of identification: the Intelligences do not wish to see something they already understand, and have no interest in participating in some kind of shared emotion. And last, if that were not enough, the fiction must appeal to many, not just a few. These rules act as a playful metacommentary on La paranoia's exploration of human perception and language, and the power of fiction to gesture toward what lies beyond the order they impose on the world, allowing us to glimpse another order: one that is chaotic, complex, and transcends the human.

Jorge Dubatti divides Spregelburd's oeuvre into two periods. He identifies the first as "metalinguistic" and deconstructive in orientation, centrally concerned with presenting "reality" as a linguistic construction and pointing to the arbitrary nature of signifiers. ${ }^{18}$ From the mid-I990s onward, however, Dubatti perceives a shift away from paradigms of language and textuality to affirm the existence of realities "que se cuelan entre las redes del lenguaje" (that seep through the nets of language).$^{19}$ Other principles of organization gain prominence in Spregelburd's work, drawn from the fields of logic, mathematics, and science, including theories of chaos and complexity. ${ }^{20}$ It comes to be characterized by a search for the existence of a principle of organization that is "extra-humano, que excede la escala del hombre, que es inaprensible desde criterios antropocéntricos" (extrahuman, that exceeds the scale of man, that cannot be grasped from an anthropocentric viewpoint). ${ }^{21}$ Dubatti argues that this shift mirrors a broader one away from the "linguistic turn" of the twentieth century. While he rather vaguely denominates this new direction a turn toward "lo real metafísico,"22 however, I will argue that it is more productively understood within the context of theories of new materialism. 
This perspective, which reconsiders the human within a broader, nonhuman set of ontologies, is evoked in the conflict of perspectives between humans and Intelligences in La paranoia. The latter, unconstrained by the human desire to derive symbolic meaning from matter, are able to perceive broader forces in the universe that cannot be captured in human language, such that "lo que para nosotros es religión para ellas es polvo, materia, y matemática elemental" (what for us is religion, for them is dust, material, and elemental mathematics). ${ }^{23}$ The Intelligences' proscription against individual character and style displaces and disperses agency across multiple beings and forms of matter. It is in fractals and chaos theory that Spregelburd discovers a patterning that is not reducible to human categories of perception and thought, a syntax of the material universe that is entirely alien to our own attempts to impose order on it. Coole and Frost observe that theories of nonlinear dynamic systems developed in physics since the I970s have drawn attention to their self-organizing properties in a way that resonates strongly with "a posthumanist sense of material agency." ${ }^{24}$

The dynamics of chaos provide inspiration for a number of formal innovations in La paranoia, as they do for many of Spregelburd's theatrical works, often allowing him to create a poetics that raises questions of meaning and order without embedding them within language. Drawing on the insights of the writer and painter Eduardo del Estal, a frequent inspiration, Spregelburd submits that "la realidad es la resistencia de las cosas a todo orden simbólico" (reality is the resistance of things to any symbolic order); ${ }^{25}$ for Spregelburd, this does not mean that reality is absurd or meaningless, but that its complex patternings do not easily yield to human observation. In Fractal (2000), the arbitrary nature of the link between the first act and the second (the sending and receiving of a videotape) simultaneously suggests and problematizes the existence of a deeper meaning that might lend coherence to the piece as a whole, encouraging us to reflect on the possibility of regimes of meaning that cannot be reduced to the linguistic or the symbolic. Spregelburd's stated preference for expressing ideas through the design of a theatrical situation rather than offloading them onto dialogues ${ }^{26}$ is often accommodated by means of experimenting with fractal-like designs for his works, in which forms are repeated, on a reduced scale, within the work itself, or through the evocation of the kind of chaotic resonances that disturb conventional causality.

In La paranoia, a wealth of such resonances is created by the juxtaposition and partial merging of the narrative spaces of the screen and the stage. Apparently unconnected scenes are linked by small but suspiciously signifi- 
cant details, provoking the spectator to consider the possibility of relationships between them that go beyond those of simple causality. For example, stage directions for the second scene call for the hanging of "curiosos tapices chinos" (strange Chinese tapestries) in the Piriápolis hotel $;{ }^{27}$ these might evoke the setting of the first scene, which narrates an episode from the Japanese invasion of China, but no explanation of any relationship between the scenes is yet forthcoming. Julia is the first to perceive links between the different narrative worlds, although the only logic she can find to explain them is one of phonetic resemblance:

JULIA: ¿"Maracatel”? . . ¡ ¡Hay un patrón! Laboratorios "Maracay,” "Maracaibo," "maracucho," "maraca" ...

HAGEN: Las maracas que le dieron a Claus ...

JULIA: "Marico," tres maricos venezolanos en La Guaira . . . Las palabras que usamos son variaciones de lo mismo.... Debe haber un patrón en lo que estamos diciendo. ${ }^{28}$

JULIA: ¿"Maracatel"? . . There's a pattern! "Maracay" Laboratories, "Maracaibo," "Maracaibans," "maraca” ...

HAGEN: The maracas Claus was given ...

JULIA: "Marico" [gay], three Venezuelan gays in La Guaira . . . The words we use are variations of the same.... There must be a logic in what we are saying.

We discover that mise en abyme and fractal-like recursion often provide the governing logic linking the different sequences: for example, both the Japanese soldier scene and the transvestite cabaret are the waking dreams of Lázaro, the Venezuelan police officer. Many of these resonances—such as the mention Julia makes of a conference in Norway, which is echoed moments later by Barragán on-screen-initially lead us to the reasonable hypothesis that the Piriápolis team is constructing fiction out of the material of their own lives. However, this belief becomes increasingly difficult to sustain, as many of the props, motifs (and even people) that cross the boundary between the world of the stage and the world of the screen are cut loose from any narrative function, taking on instead a decidedly metafictional role.

Such is the case with the "Hilandera China" (Chinese spinner), the name of a character in the Japanese soldier scene and a tarot card in the Venezuelan drama, "la que teje los destinos, y los enmaraña" (the one who weaves destinies, and tangles them up), ${ }^{29}$ and with the tiny pieces of plastic rescued 
by Hagen from the gamma disaster (and shown onstage), which are patently the same as those found by Lázaro on the floor of the laboratory (and shown on-screen). According to Hagen's explanation, the tiny colored pyramids are given names and numbers strictly on the basis of the relations between them, or more precisely, the capacity of any one pyramid to land close to another when they are thrown across the floor. Julia realizes that the "Sefaratón," as it is called, is a kind of literature that is powered by multiple possible combinations and relations, rather than an alphabet in which each sign refers to a concrete referent: "Es decir, una literatura que se redujo a valores de relaciones matemáticas" (That is to say, a literature reduced to the values of mathematical relations)..$^{30}$ Like Spregelburd's play, this "alphabet" suggests a literature that is governed by topology and material relations, rather than language, meaning, or symbolism.

Our understanding that the Piriápolis drama is the primary narrative level, to which all the others are subordinated, is completely overturned at the end of the play when it is revealed that Claus and Hagen are the names of two of Brenda's childhood teddy bears and that the entire Piriápolis team is a figment of Brenda's imagination. As in Borges's "Las ruinas circulares," the dreamer is finally revealed to be the subject of another's dream. ${ }^{31}$ However, if Borges's fiction is designed to provoke ontological uncertainty by exploring the consequences of philosophical idealism, in which "being is perception" (Berkeley), Spregelburd's dream ultimately sidelines the creative power of human perception and imagination and points instead to a patterning and a creation of forms that exceeds the human. The narratives of La paranoia are not contingent upon character or the unfolding of a drama, but on forms and processes that transcend them, and that point to the selforganizing principles of a chaotic universe. The Piriápolis team, Brenda, the Japanese soldiers, and the Venezuelan transvestites serve only to articulate the logic that produces and organizes them. It is a logic proper to chaos, of unexpected associations, unpredictable causalities, and the magnification of the insignificant.

For Spregelburd, fiction has the potential to reveal the simplifications we impose on the universe and to point beyond itself to a reality that may not be captured in language. The Intelligences' rejection of hierarchies and orders of perception is clearly absurd: it would be impossible to create a fiction that dissolved the categories of figure and background on which human perception and the construction of meaning relies, and Spregelburd readily admits that "todo acto de creación es una búsqueda de forma, un intento de dar forma a aquello que es todavía mero caos" (every act of creation is 
a search for a form, an attempt to give form to that which is, as yet, mere chaos). ${ }^{32}$ However, there are ways in which fiction may move beyond the world without meaning of the theater of the absurd, as well as the poststructuralist relegation of all meaning and reality to linguistic constructions, by gesturing toward a reality that does exist beyond our simplifications of it, and that is not cut to the measure of human perception or language. For Spregelburd, the best fiction "huye de lo general, ahonda en lo particular" (flees from the general, delves into the particular), producing examples and events that do not respond to general laws. ${ }^{33}$ It replaces linearity and causality with multiplicity, uncertainty, and complexity, and rejects psychologically coherent characters in favor of the exploration of an organizing principle that transcends the human.

La paranoia is in many ways, then, Spregelburd's own response to the challenge laid down by the Intelligences to produce a fiction in accordance with the five rules given. It undermines individuality in characters by questioning their autonomy_Lázaro is not the only character of whom it is true, as he suspects, that "alguien manipula mi vida" (someone is manipulating my life $)^{34}$ - and by merging aspects of their life stories with those of other characters, as well as subjecting human destinies to the movement of material objects and the patterns they create. It rejects "estilo" (style), defined here as the construction of similarities, by opening theater up to different disciplines and spectatorial regimes (the physics of chaos, the mathematics of fractals, and the dialogue established with the cinematographic form). It also attempts to complicate the viewer's perception of figure against background and to disrupt processes of identification. La paranoia forms part of a series of plays written and directed by Spregelburd, the Heptalogia de Hieronymus Bosch, all of which are inspired by Bosch's painting of The Seven Deadly Sins and the Four Last Things (ca. I500). As Spregelburd explains, each of his plays captures something of the spirit of Bosch's work: its infinite detail, the lack of a center, the way it encourages the eye to rove, and its nostalgia for a former order, now absent. As for the fifth rule, that the fiction should appeal to many, not just a few, it could certainly be argued that Spregelburd's play, in its use of humor and its obvious play with theatrical and generic conventions, avoids some of the pitfalls of more elitist instances of avant-garde theater.

Spregelburd's materialist approach also responds, of course, to the distinctiveness of theater in relation to literature, cinema, or visual art. In particular, it carves out a role for theater beyond the linguistic. Spregelburd prefers to consider theater a form of "contagion" rather than "communication": 
No hay para mí comunicación en el arte, ni en el teatro, en sentido estricto. Lo que hay son otras formas de contacto. Yo la llamo "contagio." Contagio de impresiones, de temores, de intuiciones aún sin nombre, aún fuera de lo lexicalizable. ${ }^{35}$

For me, there is no communication as such in art, nor in theater, in the strictest sense. There are other forms of contact instead. I call it "contagion." Contagion of impressions, fears, intuitions as yet unnamed, as yet beyond that which may be lexicalized.

Theater may experiment with other forms of contact and interaction because it is embedded in a embodied performance that necessarily takes place within the context of a gathering, or what Dubatti has theorized as "convivio teatral" (theatrical gathering). As Dubatti suggests, the situated and territorialized nature of "convivio teatral" acts to preserve the culture of orality and presence in a lettered society that is increasingly governed by virtual communications. ${ }^{36}$ In its emphasis on embodied performance, presence, event, and process rather than language and representation, Spregelburd's theater shares some features with "postdramatic" theater as analyzed by Hans-Thies Lehmann. The particular advantage of this framework, in comparison to other performance studies approaches, is that it articulates a link between postdramatic theater from the 1960 s to the present day and the historical avant-garde, which - most notably in the theater of Antonin Artaud-also challenged the dominance of the text by drawing attention to the materiality of performance. ${ }^{37}$

Heredia argues that the composition strategies of Daulte's $4 D$ Optico are closely related to the aesthetic practices of the neobaroque as a cultural dominant in our era, a moment marked by "el exceso, la inestabilidad, el cambio y lo polidimensional" (excess, instability, change, and the polydimensional). ${ }^{38}$ Spregelburd's work also invites characterization of this kind. Transmitting the wishes of the Intelligences to the humans waiting on earth below, the robot assistant in La paranoia continually repeats the word "pliegue" (fold); to the frustration of the Piriápolis team, she misses the all-important explanation of what is being discussed, and so the word is left hanging, opaquely. In the context of the play's multiple mirrorings, metacommentaries, and mises en abyme, however, one would be justified in reading it alongside Deleuze's work on the "fold" as "the criterion or operative concept of the Baroque." 39

Expanding on Deleuze's notion of the fold in relation to baroque fictions, both of seventeenth-century Spain and of twentieth-century Argen- 
tina, Carlos Gamerro finds the central feature of the baroque to lie in the quest to "intercambiar, plegar o mezclar" (exchange, fold, or mix together) different planes of reality-

ficción/verdad, cuadro/modelo, copia/original, reflejo/objeto, imaginación/percepción, imaginación/recuerdo, sueño/vigilia, locura/cordura, teatro/mundo, obra/autor, arte/vida, signo/referente

fiction/truth, painting/model, copy/original, reflection/object, imagination/perception, imagination/memory, dream/wakefulness, madness/sanity, theater/world, work/author, art/life, sign/referent

-in order to disrupt simple binaries and invert hierarchies, emphasizing "el compuesto calidoscópio, siempre cambiante, que surge de todas estas combinaciones y entrecruzamientos" (the kaleidoscopic, always shifting compound that arises from all these combinations and crossings-over). ${ }^{40}$ In Deleuze's reading of Leibniz's writings, these not only provide a key to understanding the baroque as a philosophy and set of aesthetic practices, but also prefigure contemporary scientific theories of matter, both organic and inorganic, pointing to a complex understanding of subjectivity in which the inside is always the outside folded in, and the human opens out to nonhuman forces that are then folded in to produce new modes of expression and experience. This dynamic is central to new materialist perspectives on posthuman subjectivity; it also links Spregelburd's dramaturgy with the novels of Marcelo Cohen, whose work-I will suggest—marks a similar move away from a linguistic paradigm to a materialist one and explores what this might mean for our understanding of the act of writing.

New Subjectivities and New Materialisms in Marcelo Cohen's Metafictions

Many of Marcelo Cohen's novels and short stories establish a dialogue with scientific theories of chaos and complexity in order to construct a vision of radical immanence, in which human and nonhuman realms are caught up in multiple exchanges and mutual transformations within a material universe. ${ }^{41}$ His work consistently decenters the human subject as a locus of agency, choosing instead to present agency as distributed across both organic and inorganic matter. The view of the material world that emerges from his 
fiction is very similar to that proposed by new materialists, for whom matter-in De Landa's words - is not "an inert receptacle for forms that come from the outside," but rather "an active matter endowed with its own tendencies and capacities, engaged in its own divergent, open-ended evolution, animated from within by immanent patterns of being and becoming." 42

In its exploration of the multiple, mutable subject, Variedades (1998) starts to dismantle what Jacques Rancière calls "the metaphysics of representation" ${ }^{13}$ and to imagine how we might understand the act of authorship in the absence of a coherent, centered self. In Donde yo no estaba (2006), Cohen extends these ideas to consider how we might conceive the exercise of writing within a thoroughly materialist conception of the universe. Braidotti places emphasis in her recent work on the importance of Deleuze's thought as a crucial precursor to new materialism, and my reading of Cohen's texts will also trace resonances with the Deleuzean concept of "becoming imperceptible" as a way of abandoning the metaphysics of representation and of locating the act of writing as immanent to the material world, rather than above it or imposing form upon it.

\section{Variedades: Abandoning the Metaphysics of}

Representation and the Hermeneutics of Suspicion

In Variedades we find ourselves in a hypermediatized society in which celebrity images are even bigger business than they are in our own world. The Baron de Marut and his wife Finita Vitasti are the media stars of the moment. The media company charged with managing their image approaches the narrator with an unusual proposition: to undertake, under contract, to appear as the baron at various media events, in order to increase his exposure, and thereby the company's revenue. The (nameless) narrator undergoes extensive plastic surgery and studies the gestures and vocal mannerisms of the real baron at length before his first public appearance. Everything proceeds according to plan for some time, and he becomes accustomed to his new life, even conveniently falling in love with his consort, Mansi (Finita's double). Unfortunately, the baron's unscripted strangling of his wife sets in motion a series of events that will see the narrator decommissioned from his role and his face altered once again: this time quite arbitrarily to form the likeness of Rembrandt's son, copied from a painting admired by the plastic surgeon.

Such precipitous changes in the narrator's appearance drive him into an existential crisis. He is unable to maintain the illusion of a coherent self that 
would remain consistent throughout his different roles and the various reconstructions of his face. He longs to be able to point to something and say, "Esto soy yo a pesar del tiempo" (That is me, despite the passage of time), ${ }^{44}$ but instead fears that he is merely "un tic tac de creación y borrado, sucesivas formas instantáneas bajo una luz estroboscópica" (a ticktock of creation and deletion, successive instantaneous forms beneath a strobe light). ${ }^{45}$ This revelation echoes Hume's empiricist vision, according to which the self is "nothing but a bundle or collection of different perceptions, which succeed each other with an inconceivable rapidity, and are in a perpetual flux and movement." ${ }^{36}$ The narrator of Variedades discovers, in a similar way, that he is simply the sum of the multiple roles and appearances he has adopted: there is no essence of the self that endures alongside, or in spite of, these. $\mathrm{He}$ realizes that "yo era un espacio de confluencia" (I was a space of confluence), and that it is only the illusory continuity of our perceptions that allows us to deduce the notion of "un elemento aglomerador" (an element that binds them together). ${ }^{47}$

This radically unstable understanding of the self is at the root of the narrator's difficulties in writing his story. The question of literary style presents him with the worst dilemma: he wonders "cómo conseguir un estilo, modesto pero duradero, cuando uno, yo, intuye que lo único de duradero que hay en uno es, intentaré formularlo, una sucesión de lo que va mostrando en su existir. Acciones. Momentos. O, en mi caso, caras" (how to acquire a style, modest but long-lasting, when one-I-intuits that the only long-lasting thing that exists in one is, I will try to express it, a succession of what one shows throughout one's life. Actions. Moments. Or, in my case, faces). ${ }^{48}$ While a strong sense of individual style eludes him, he recognizes that developing one would only give the illusion of a coherence that does not exist. He criticizes his own choice of style as one that is too suggestive of a permanence of self, commenting in parentheses:

Este estilo no me gusta. Aunque tal vez sea más ágil, el uso del presente histórico me acerca demasiado al personaje cuyas peripecias estoy redactando, como si ese personaje fuera casi yo; cuando en realidad ahora soy otro, y dentro de un rato podría ser otro más. Así que vuelvo al pretérito indefinido, recio escudo del redactor de historias. ${ }^{49}$

I don't like this style. Although it might be more agile, the use of the historical present brings me too close to the character whose adventures I am writing up, almost as if that character were me; when in re- 
ality I am now another, and in a little while I might be yet another. So I will return to the indefinite preterit, the storywriter's sturdy shield.

The narrator is often paralyzed in his literary endeavors by the recognition of what Rancière refers to as "the irreconcilable multiplicity of individuals contained within what we call an individual," 50 and struggles to find a style that might express something of that jumble of different moments and faces. He realizes that a belief in the coherence of our selves is only reinforced by language, "con su tendencia al estilo personal" (with its tendency toward personal style), which "distingue y petrifica" (differentiates and petrifies). Language promotes the illusion of selfhood, under-as Braidotti phrases it- "the fictional unity of a grammatical 'I."' 51

However, this tendency "puede paliarse, si uno se atreve, redactando sin estilo" (can be diminished, if one dares, writing without style), ${ }^{52}$ and this becomes the narrator's goal in Variedades. The narrator introduces shifts within his own use of language-lexicon, tense, narrative structure-throughout the novella, in an attempt to undermine the emergence of a single, coherent style and to reflect the shifting multiplicity of subjective experience. Literature is consistently represented in Variedades as a process of exchange and mutation rather than a coherent, finished text produced by a single author. In Cohen's imagined society, literature enjoys a moment of tangible revival, in which writers and readers stop by the communal boards in the main city square to post up their stories and write comments in the margins of others. The narrator posts draft chapters of his own story-the one we read-on the boards in the square, returning anxiously to discover his readers' critiques and suggestions for redrafting. Writing has become a thoroughly interactive exercise: he converses with his critics, thanking them for their comments and attempting to remedy the deficiencies of his style in the next installment of the narrative.

Most importantly, Cohen presents writing as a radical act of creating new relations and subjectivities rather than an exercise in mimesis. This leads him away from a understanding of literature as representation and toward one that has much in common with Deleuze's conceptualization of art's role in becoming other. Cohen counters the "hermeneutics of suspicion" 53 that has underpinned Marxist, Freudian, and deconstructive approaches through a rejection of a "depth model" of literature, in which words gesture to something else that might exist independently from them. The narrator knows that he must reject polarities such as "hondo/llano, fondo/aspecto" (deep/ flat, background/form), as these are artificial and unproductive opposi- 
tions ${ }^{54} \mathrm{He}$ also dismisses the metaphorical expression "quitarse la máscara" (to take off one's mask), with its meaning of showing one's true face or self, as "un disparate" (an absurdity), as there is nothing beneath the mask: the mask is all there is. ${ }^{55}$ For Deleuze, similarly, "It is not that we have a self that we then conceal or express through simulation or performance. ... The idea of an original or underlying self or essence is the effect of the produced masks and copies." 56

This proposition - that the image is all there is — does not lead in Deleuze to any kind of nihilism. While many theorists of the postmodern-Jameson and Baudrillard, among others-have lamented the occlusion of reality via an endlessly proliferating series of simulacra, Deleuze does not express any nostalgia for some previous moment in history in which we were more in contact with reality than we are now. As Claire Colebrook suggests, Deleuze "provides a positive definition of the image. Images are not pale replicas or second-rate versions of a real world. Images are fully real, from the images produced by a camera to the images produced by the eye that expects what lies beyond its immediate viewpoint." ${ }^{57}$ In Deleuze's empiricist philosophy, no world exists separately beyond our perceptions and images of it. This understanding challenges dominant conceptions of our postmodern era as one that has lost touch with reality, beset by the myriad images, copies, and simulations of television and advertising.

Cohen's empiricist approach tempers and complicates what might otherwise be a straightforward denunciation of the powerful distortions of the mass media in a future society not so different from our own. His interest is not primarily in showing how image-making or writing betrays a reality that lies beyond it, but in presenting both as creative processes that generate new forms of perception rather than revealing or representing hidden truths. Rancière, drawing on Deleuze's theorizations, ${ }^{58}$ observes,

For literature to assert its own power, it is not enough for it to abandon the norms and hierarchies of mimesis. It must abandon the metaphysics of representation and the "nature" on which it is founded: its modes of presentation of individuals and the connections between individuals; its modes of causality and inference; in short its entire system of signification.

The power of literature must then be sought in that zone before representative sequences, where other modes of presentation, individuation, and connection operate. ${ }^{59}$ 
Cohen's purpose, in Variedades and in a number of his other fictions, seems to be to stage an experiment in abandoning "the metaphysics of representation" in precisely this manner. He attempts to undo individuation by insisting on the multiple and provisional nature of the self as the locus of perceptions, and to present literature as emerging from this preindividuated, unstable zone of affects and relations.

The abandonment of the hermeneutics of suspicion would become even more marked in Donde yo no estaba, in which Cohen describes a "cultura de sospecha" (culture of suspicion) that had reigned for many decades in the past, in which the media were accused of inventing reality and "la gente culta era muy dada a la crítica ideológica, a la desconfianza defensiva" (educated people were very much given to ideological critique and a defensive mistrust). In this novel, too, he develops in greater depth an understanding of writing as an act that reveals_ and performs_-our embeddedness as human subjects within a material world of continual transformation and exchange.

\section{From Mimesis to Metabolism: Writing and}

Becoming-Imperceptible in Donde yo no estaba

Cohen's Donde yo no estaba, like many of his fictions, is replete with electronic and mechanical prostheses that extend the consciousness and capacities of his human subjects to the inanimate objects that surround them. The tax inspector has a prosthetic device referred to as an "agente recordatorio" (reminder agent) attached to his right arm and connected by fiber optic cables to his tendons, which helps him detect instances of tax evasion as well as controlling his cardiac rhythm and blood pressure, and alerting him to the presence of insane individuals who might be a threat to him. ${ }^{60}$ Other devices also act directly on the brain or senses of humans, including the "estimulador cutáneo" (cutaneous stimulator) by Aliano's bedside and various inventions designed to trigger memories of the past. A kind of virtual multisensory network, the Panconciencia, allows individuals to enter the conscious minds of other citizens, seeing and hearing what they experience. As he connects up, Aliano describes becoming aware of "el vocerío del multiverso interior" (the clamor coming from the interior multiverse) and reflects that "mi historia personal ya no era cosa solitaria" (my individual past was no longer a solitary thing). ${ }^{61}$

The use of prostheses always unleashes forces of dispersion in Cohen's 
characters. In Donde yo no estaba, for example, Yónder is implanted with a kind of compendium of public relations methods to assist him in his mission to the Baluga islands, but this is later hijacked by a writer who uses him as a spokesperson for his seditious pamphleteering. His conscious mind has become distributed across multiple presences. This impact of this kind of prosthesis is only a more hyperbolic instance of the kind of mutual interpenetrations that complicate notions of selfhood through Cohen's novel, however. The self-effacing and rather conventional Aliano, forced by circumstance to develop a relationship with this troubled, repulsive youth, begins to refer to "el Yónder-en-mî" (the Yónder-in-me) to describe those parts of his mind that have entered into some kind of encounter or fusion with Yónder, while other parts ("lo que en mí no es Yónder," what in me is not Yónder) remain at least comparatively separate. ${ }^{62}$

While managing multiple presences within their consciousness causes the characters some difficulty, the dissolution of the coherent self becomes Aliano's central creed. He aspires to an "adelgazamiento del ser" (slimming of the self) ${ }^{63}$ which recognizes that "el yo es una prenda sin contenido" ("I" is a garment with nothing inside) ${ }^{64}$ It is a desire expressed succinctly in the words of an apocryphal poet, transcribed by Aliano in his diary: "Dame, genio de la lámpara / la opción de disolver mi forma / en la injustificada sopa química / donde las formas se deshacen y vuelven a hacerse / por toda la eternidad" (Give me, genie of the lamp / the choice to dissolve my form / in that arbitrary chemical soup / where forms melt and remake themselves / for all eternity). ${ }^{65}$ Aliano's guru teaches that "un buen procedimiento de despersonalización es ingerir lo que de sus personas suelten otros, y en el mismo acto evacuar parte de uno" (a good method for depersonalization is to ingest what others let go from themselves, and in the same process evacuate part of oneself). ${ }^{66}$ This simultaneous emptying out and folding in of the world around posits the self merely as the locus of relations with its environment and introduces a radical philosophy of immanence.

The subject that emerges has a great deal in common with the "nomadic" and "posthuman" subjects theorized by Braidotti, who draws explicitly on a tradition of monist ontology and vitalist materialism. Within this perspective, "The subject is a transversal entity, fully immersed in and immanent to a network of nonhuman (animal, vegetable, viral) relations ... shot through with relational linkages of the contaminating/viral kind which inter-connect it to a variety of others, starting from the environmental or eco-others and including the technological apparatus. ${ }^{967}$ Braidotti's recourse to the vocabu- 
lary of viral contamination here echoes Aliano's realization in Donde yo no estaba that he and Yónder "nos parasitamos mútuamente" (are engaged in mutual parasitism). ${ }^{68}$ Her account of the human subject as embedded in relations with the natural and technological environment also accords with the complex relations between the human and the nonhuman in Cohen's many cyborg figures.

The primary framework for Cohen's immanent worlds may well be a Buddhist one: the principle of nondualism advanced by Aliano's gurus has much in common with the kind of teaching on "el obstáculo del yo" that Cohen summarizes in his introductory text on Buddhism. ${ }^{69}$ As Cohen himself recognizes, however, a rejection of the opposition between subject and object also has roots in Western thought, from Nietzsche to the poet Fernando Pessoa and the physicist Erwin Schrödinger. ${ }^{70}$ It also bears the legacy of Spinoza's monism. As Deleuze suggests in his work on Spinoza,

An animal, a thing is never separable from its relations with the world. The interior is only a selected exterior, and the exterior, a projected interior. The speed and slowness of metabolisms, perceptions, actions and reactions, link together to constitute a particular individual in the world. ${ }^{71}$

Deleuze's choice of the term "metabolism" becomes extremely significant in relation to Cohen's writing, as the kind of material exchanges his characters undergo with their environment are often described with reference to metabolic processes and the ingestion and evacuation of food and liquids. Aliano reads from the writings of his guru that

Somos lo que comemos. . . . no tenemos ningún carácter, moral, identidad ni nada en que reconocernos salvo los procesos químicos que se obran entre lo que nos metemos por la boca y los jugos gástricos. Líquido amniótico, leche de teta: con eso empieza todo. Después comemos carne o papas y la química más compleja, la del cerebro, produce una friolera de ilusiones, por ejemplo la del ser. ${ }^{72}$

We are what we eat. . . . we have no character, ethics, identity nor anything in which we may recognize ourselves except the chemical processes that take place between what we put in our mouths and our gastric juices. Amniotic liquid, breast milk: everything begins with 
that. After that we eat meat or potatoes and a more complex chemistry, that of the brain, produces a series of mere illusions, for example that of the self.

Within this materialist conception of subjectivity, the borders of the self dissolve, leaving no room for dualistic thought. This understanding reveals, first, the speciousness of any mind/body distinction. For Cohen, even the act of reading, so apparently cerebral and abstract, may reveal to us how thoroughly our consciousness is mired in chemistry: Aliano remarks on the fact that reading Lumel's poetry floods his body with endomorphins that lessen his headache. ${ }^{73}$ Second, it confuses any distinction between the self and the other. Aliano realizes that "soy la flor y el jardinero. De todo hay en mí un poco" (I am the flower and the gardener. There is a bit of everything in me). ${ }^{74}$ And third, it returns to the material world the agency erroneously ascribed only to humans. As the world, oneself, everyone else, and what people think are part of the same substance, Aliano affirms, "Lo que vemos ve. Lo que oímos oye" (What we see, sees, and what we hear, hears). ${ }^{75}$

In a number of his narratives, Cohen extends this materialist vision to explore the nature of writing in a posthuman, nondualistic universe. How might a perception of radical immanence affect our understanding of the role of the writer and the act of writing itself? Aliano refuses to be governed by the climaxes and dénouements of novel-writing and its search for "la máquina encubierta" (the hidden machine) that brings form and resolution to a story, ${ }^{76}$ choosing instead to compose a diary into which he consciously enfolds the banalities and excesses of everyday life in such a way that the diary seems coextensive with lived time. Even so, he is horrified that he continues to recognize himself in his writing, despite his resolution to dissolve any sense of the self. A metaphor here, a syntactical flourish there: all bear witness to his manipulation of life in writing. ${ }^{77}$ This horror does not stem from a desire for writing to represent the world without the distortion of a mediator. Instead, it expresses Aliano's desire to "deshincharse" (deflate oneself) in order to "hacer lugar a los otros" (make room for others). ${ }^{78}$

Cohen draws on the same metabolic processes that govern subjectivity in his texts to describe writing as a form of exchange and transformation: Aliano decides that "voy a escribir como se come" (I am going to write in the same way as one eats), going on to explain that the stomach returns to the earth almost exactly what the earth gives it, minus the few grams it needs to keep the body functioning. ${ }^{79}$ Writing becomes an exercise in losing one's 
self and ingesting the work of others. Lumel, a rather eccentric woman with whom Aliano starts a relationship, composes poems that consist of texts written by others, pieces of informative prose that set out, variously, local myths in relation to river eels, the details of a pathology investigation, or the traditional customs of the region's goatherds. Retyped in verse form, these acquire a simple elegance that does not detract from their earthiness and lack of literary pretension. Aliano admires her poetry greatly, considering it to be more durable as it draws on the work of others. He refers to "la valentía de ser mero marco de un hacer ajeno; aunque lo valiente sería no ser siquiera un marco, porque hay marcos muy llamativos" (the courage to be a mere frame for another's work; although real courage would be not to be a frame at all, because frames can be very striking)..$^{80}$

Cohen also experiments in Donde yo no estaba with syntactical choices that convey the importance of relations and becoming rather than substance or essence. Infinitives replace conjugated verbs in a way that emphasizes movement or processes of transformation over the subject as agent: Aliano pronounces, "Que la vida pase por los verbos. Ocasear. Aguar. Verdear. Trinar. Enlunecer. Acompañar. Espaciar. Durar. Estañar" (May life happen in verbs. To sunset. To water. To green. To chirp. To moonize. To accompany. To spread out. To last. To solder). ${ }^{81}$ Ideas and phrases often circulate independently of the subjects who utter them, and unprepared switching between third and first persons further undermines the concept of a bounded self, giving expression to the mental interferences and exchanges that mark relationships between the self and other in Cohen's fiction.

There are significant similarities between Cohen's understanding of writing as an exercise in losing one's self and Deleuze's conceptualization of art as a practice of "becoming imperceptible." Braidotti emphasizes the importance of this principle within materialist, posthuman thought. Becoming imperceptible "marks the point of evacuation or evanescence of the bounded selves and their merger into the milieu" 82 and opens up the human to other realms of agency: "By transposing us beyond the confines of bound identities, art becomes necessarily inhuman in the sense of nonhuman in that it connects to the animal, the vegetable, earthy and planetary forces that surround us." ${ }^{83}$ It is Aliano's relationship with the bionic animal Keto that reveals to him that "el lenguaje es inhumano" (language is inhuman), that is, not exclusive to humanity. ${ }^{84}$ For Cohen, the posthuman condition allows us to grasp the extent to which we are immersed in a material world of continual transformation. 


\section{Conclusion: The "Eternal Dance of Atoms"}

Braidotti observes that postanthropocentrism most frequently figures in science fiction and popular culture in the mode of "neo-gothic horror," articulating a deep-seated anxiety about the transformation of relations between the human and the technology. She labels this "narrow and negative" imaginary "techno-teratological." ${ }^{85}$ Like Haraway, she also sees in this moment of fluidity a vital opportunity to decenter (post)modernist thought on the body and to reposition the human in relation to the nonhuman. Spregelburd and Cohen take up this challenge, exploring modes of writing that emphasize the material relations that define human subjectivity and gesturing beyond anthropocentrism to an understanding of agency that embraces both human and nonhuman, organic and inorganic, forces. If Spregelburd explores extralinguistic realms of experience and order, Cohen pushes at the limits of language, allowing us to glimpse ways in which it might actually decenter the human and express something of our relationship with the material world.

For all its deconstructive zeal, postmodern and poststructuralist thought effectively leaves intact a dichotomy between language and reality and often entirely sidelines the real/material as entirely constituted by language. ${ }^{86}$ As John Smith and Chris Jenks argue, "Radical constructivisms rest on the over-estimation of human construction and authorship," having "the unintended effect of recentering the human subject as the locus of agency despite the intention to undermine such claims." ${ }^{87}$ New materialism questions the anthropocentric assumptions of the linguistic-constructivist paradigm and replaces it with one of radical immanence.

What Spregelburd and Cohen allow us to appreciate is the potential in literary texts or theatrical performance to gesture toward the material realm and to displace and decenter human subjectivity. Colebrook suggests that "literary language, by deforming the syntax and grammar that enables efficient, striving, and self-maintaining life, frees human thought from its own rhythms and propensities." 88 This process of deforming and defamiliarizing is clearly at work in the syntactical play of Cohen's fiction, but it is also visible in the folded hierarchies of Spregelburd's dramatic narratives. The power of literary or theatrical language in both cases does not rest in a capacity to transcend lived reality and take up a privileged position in order to deconstruct its dynamics, but in its ability to immerse us as readers or spectators within a complex, material universe, subject to continual transformation, in which human agency is only one force among many. This vision of multiple becomings within a creative universe resonates strongly with Deleuzean 
thought, but also has much in common with Rancière's understanding of the politics of aesthetics. For Rancière, "The unique power of literature finds its source in that zone of indeterminacy where former individuations are undone, where the eternal dance of atoms composes new figures and intensities every moment." ${ }^{89}$ The redistribution of subjectivity that takes place within artistic practices becomes central to their potential to challenge the dominant system of ordering the world. 


\section{6 / Modernity and Cinematic Time in Science Fiction Film}

The eight-year-old protagonist of Valentin (Alejandro Agresti, 2002) dreams of becoming an astronaut. Sadly, his ambition is unlikely to propel him much further than lumbering around his apartment in an oversized white overall, kitted out with a vacuum cleaner hose and a couple of old soda siphons. As his family explains, to have any chance of fulfilling such an aspiration he would need to have been born in Russia or North America, and certainly not Argentina. For related reasons, perhaps, incursions into the science fiction genre in Argentine cinema have been relatively rare. The high-budget special effects that are a hallmark of the genre in Hollywood or Europe present a challenge to most filmmakers, as, perhaps, does the broader difficulty of imagining Argentina, with its chronic underfunding of scientific research, at the spearhead of intergalactic missions. In the farcical Adiós querida luna (Fernando Spiner, 2004), when Argentina does embark on an improbable space odyssey to save the planet, the government callously kills off its own astronauts in an attempt to appease the world's disgruntled superpowers, which have imposed economic sanctions as punishment for such audacious unilateralism.

It is unsurprising, therefore, that most of Argentina's few science fiction films have drawn on the more metaphysical concerns-paradoxes of time and space — of the nation's very rich heritage in fantastic literature. Examples would include the highly acclaimed Invasion (Hugo Santiago, 1969), with a script written by Borges and Bioy Casares, and the more recent Moebius (Gustavo R. Mosquera, 1996), which also acknowledges an important debt 
by naming a subway station after Borges. In other films, the "credibility gap" that has rendered implausible Argentina's role in pioneering space-age technology has been bridged in two principal ways: through retrofuturism, and through a reflexive and parodic treatment of the codes of the science fiction genre itself. The two films that provide the focus for the first part of this chapter, Estrellas (Federico León and Marcos Martínez, 2007) and Cóndor Crux, la leyenda del futuro (Juan Pablo Buscarini and Swan Glecer, 2000), adopt a highly self-conscious approach, exploiting the ironies that arise when the science fiction genre is torn from its more usual domain in a hypermodernized First (or Second) World. Examples of the retrofuturistic variant include two films that will form the basis of discussion in the second part, La sonámbula (Fernando Spiner, 1998) and La antena (Esteban Sapir, 2007), both of which also reflect specifically on the role of cinema, and the cinematic apparatus, in the registering and reshaping of temporalities.

My discussion brings together and advances a number of themes that have acquired significance in previous chapters, including technics, time, prosthesis, modernity, and materialist readings of culture. As we will see, these films do not respond in a straightforward manner to a Marxist historical-materialist understanding of how cultural texts may either reproduce or critique the social and economic conditions of their production. Instead, they employ reflexive strategies, and particularly a focus on cinema as technics in Stiegler's sense, to launch a broader challenge to the temporality of both modernity and historicism. While often playful in their execution, these films present a more serious critique of modernity's construction of time as linear and irreversible, and of the discourses of progress that underpin capitalism. This particular construction of time has been the object of an urgent postcolonial critique of historicism that has recently been undertaken by Dipesh Chakrabarty and Bliss Cua Lim, among others. Far from lamenting cinema's role in the projection of the linear temporality of modernity, however, these films amply demonstrate the capacity of cinema to construct and interweave different temporalities, and thereby to produce alternative visions of the past and the future.

Polytemporality in Estrellas and Cóndor Crux: A Critique of the Homogeneous Time of Historicism and Modernity

The question of the historicity of science fiction divides two prominent theorists of the genre, Fredric Jameson and Carl Freedman. They agree on a 
basic definition of historicity, as a defamiliarizing, distancing quality that gives us a historical perspective on the immediacy of the present, allowing us to understand its place within a web of causes and effects. ${ }^{1}$ For Freedman, "Science fiction is of all genres the most devoted to historical concreteness"; he even suggests that "science fiction is, perhaps paradoxically, a version of historical fiction." ${ }^{2}$ This is because the defamiliarizing effects of science fiction produce exactly that distancing with regard to the present which is essential to a historical perspective; furthermore, science fiction inserts that present into a dialectical play between identity and difference, constructing society as mutable and determined by complex causes in a way similar to the historical novel as analyzed by Georg Lukács. ${ }^{3}$ As Freedman states, "The science-fictional world is not only one different in time and place to our own, but one whose chief interest is precisely the difference that such difference makes."

For Jameson, on the other hand, writing from a Marxist perspective, the historical novel arises in conjunction with "the emergence of historicity" in modern thought, while science fiction "corresponds to the waning or the blockage of that historicity" in the postmodern context. ${ }^{5}$ Jameson's assessment of the historicity of science fiction is not consistent across his work, however. In later analyses, he acknowledges that science fiction, unlike fantasy, does retain a sense of history, ${ }^{6}$ and that at least in the mid-twentieth century (and particularly in the work of Philip K. Dick), it "renders our present historical by turning it into the past of a fantasized future." recent science fiction fulfills, he claims, the important purpose of making us aware of our "mental and ideological imprisonment" in the present, ${ }^{8}$ by "dramatiz[ing] our incapacity to imagine the future" as radically different from our current moment. ${ }^{9}$ In other words, it succeeds precisely where it fails to convince us with its visions of a future that is qualitatively different from the present. For the most part, however, Jameson rehearses this argument in purely negative terms, reading science fiction as emblematic of the "crisis and paralysis" of historicity in postmodern culture. ${ }^{10}$ If, for Jameson, thinking historically (in a Marxist framework) means constructing linear relationships of causality that link the past to its sequel in the present, it is entirely logical that postmodernism's "omnipresent and indiscriminate appetite for dead styles and fashions"11 should represent for him a crisis in such historical thinking and point to our era's inability to engage critically with the present.

With greater insight, however, Walter Benjamin saw that "the concept of the historical progress of mankind cannot be sundered from the concept of its progression through a homogeneous, empty time. A critique of the con- 
cept of such a progression must be the basis of any criticism of the concept of progress itself." ${ }^{12}$ This is precisely the critique mounted by the Argentine films I present here. It is their disruption of linear and homogeneous notions of temporality that permits them to dismantle the logic of modernity, progress, and capitalism. As Scott McQuire reminds us, "Lamentations concerning the 'disappearance of history' so easily mask the mourning for the disappearance of a particular kind of history: the dream of continuous history which comforted the Western subject with an image of its own sovereignty." ${ }^{13}$ In place of the doctrine of the inevitability and the acceleration of the homogenizing forces of globalization, these films offer alternative visions: first, a more accurate understanding of modernity as a coproduction between the First World and its postcolonial other, and second, an appreciation of the multiple and heterogeneous temporalities that have shaped, and will continue to shape, our experience of modernity.

\section{Scrapyard Spaceships: Amateurism and Anachronism in Estrellas}

For Freedman, drawing on Darko Suvin's seminal work, the historicizing function of science fiction largely lies in the effect of "cognitive estrangement" it produces in relation to the present. ${ }^{14} \mathrm{He}$ cites H. G. Wells as a prime example of a science fiction author who demonstrates a sophisticated and critical historical understanding of his imperialist European present. In The War of the Worlds (I898), Freedman indicates, Wells creates "a genuinely anti-imperialist novel" that works "to estrange British colonialism by showing Britain itself in the (then but not later) almost unimaginable position of colonial victim." 15 The deliberately anachronistic and highly reflexive approach pursued in Federico León and Marcos Martínez’s film Estrellas performs a similar estrangement operation, producing another "almost unimaginable" vision: a science fiction film made in a shantytown. As it does so, it exposes the embeddedness of science fiction, futuristic visions, and alien encounters within certain (North American and European) narratives of technological modernity. In its portrayal of the encounter between advanced First World filmmaking and deprived shantytown communities, it challenges the linear notion of temporality that underpins accounts of a modernity rolled out from Europe to the colonies, and that allows cultural, social, or economic difference in the colonized other to be recast as historical anachronism.

Estrellas is a playful documentary about an entrepreneur (Julio Arrieta) 
who sets up a theater company in a Buenos Aires villa (shantytown) to provide work for its inhabitants as authentic-looking extras in films about poverty, corruption, or violence. The film passes caustic comment on the construction of authenticity in contemporary cinema: the measure of success enjoyed by the theater group is clearly linked to the fascination of contemporary spectators with the "real" and our propensity to look for it in the experience of lower social classes. As a cinephile says to one of the villero (shantytown-dweller) actors, with no hint of irony, "Está de moda la marginalidad" (Marginality is the fashion now). A crucial part of Julio's selfappointed role as mediator between the villeros and film directors involves minimizing the clash of two very different time regimes, as the former are thrust with little preparation into the rigorous time-compression of competitive capitalist production, in an industry in which each additional day's shooting can cost thousands of dollars. Julio hastens to reassure directors that he will be able to limit the costs of such a risky collaboration, promising to make sure that the actors are quiet when the cameras roll and don't slope off before the end of the day. Time, Barbara Adam observes, has proved "a most effective colonizing tool": as commodified time becomes the unquestioned mainspring of industry, "Any group or society that deviates from this 'norm' or endeavours to question its wisdom, value and desirability is considered backward, lazy, uncivilized." 16

While cheerfully continuing to market his actors for typical roles as thieves and drug dealers, Julio embarks on an enterprise of a rather different nature: to make a science fiction film in the villa. It is conceived as an attempt to displace hackneyed representations of the villa and to defy the conventions of the science fiction genre, wrenched from its customary coordinates in the highly modernized metropolises of the developed world. Julio asks: “¿Acaso los villeros no tenemos el derecho de tener marcianos?” (Don't we have the right to have Martians here in the shantytown?). The question, rhetorical and amusing, nevertheless emphasizes the stark anachronism of creating science fiction in a space often considered to be one of modernity's wastelands. As in the later District 9 (Neill Blomkamp, 2009) and Attack the Block (Joe Cornish, 20II), science fiction films set respectively in a Johannesburg shantytown and a deprived London tower block, the contrast serves to heighten themes of social exclusion and prejudice.

Scenes from the making of the science fiction film are incorporated in Estrellas, and the directors lose no opportunities for fun, highlighting the amateurish character of the project by including outtakes and unedited scenes without proper lighting or postproduction work. In filming breaks, 


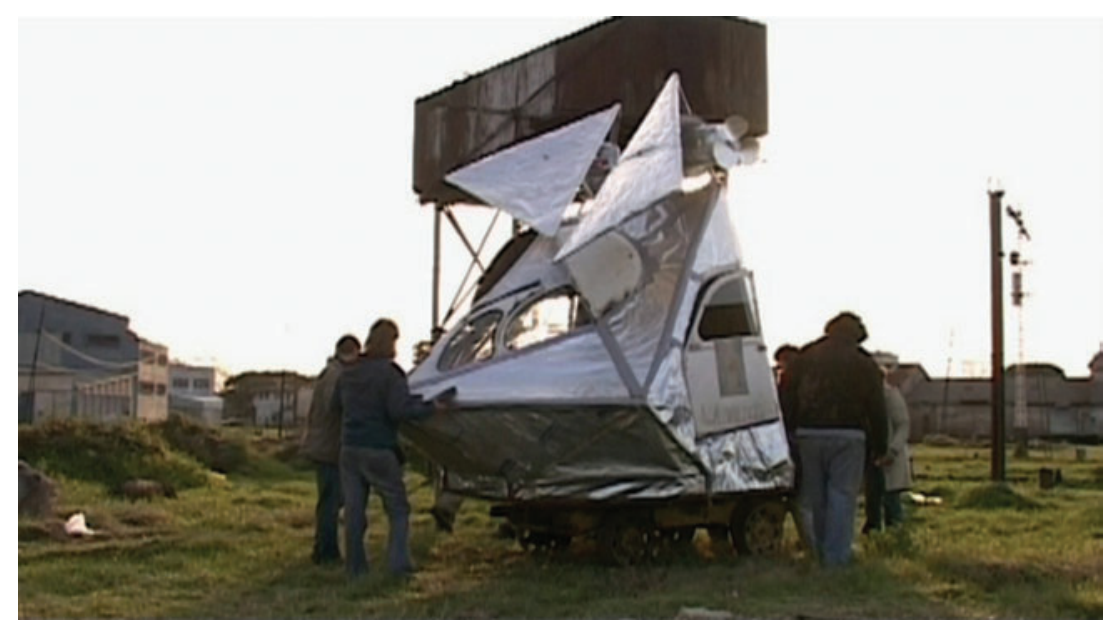

Fig. 15. Estrellas (Federico León and Marcos Martínez, 2007)

the bored "aliens" remove their headgear to indulge in a little name-calling and engage in desultory fisticuffs; shooting is interrupted by noisy kids and the incoherent singing of a local drunk. The spacecraft used in the film (see fig. 15 ) is assembled from a miscellany of unwanted junk: the body of an old Citroën, with bicycle handlebars and a floor-polisher attached to the side to simulate a fulminating weapon of attack. The construction is then mounted on an old train handcar pulled by the film crew along disused rail tracks. "Apenas se le ven las patitas" (You can hardly see their feet) boasts Julio, as the camera cuts to a flimsy tin-foil contraption that leaves rather too visible the legs of the crew as they run alongside it.

Although the film trailer we later see covers up these infelicities with a generous supply of dry ice and lighting effects, the behind-the-scenes shots included in Estrellas do nothing to render any more plausible an image of the villeros prevailing against the superior technology and organization of the alien invaders. Indeed, the film does not allow science fiction any credible footing in the villa. As Clara Kriger suggests, the homemade costumes and props "resultan impregnados por una estética kitch para el ojo del espectador" (become imbued with a kitsch aesthetic in the spectator's view), arousing fond memories of the comical Martian outfits and wobbly flying saucers of 1950 O B movies. ${ }^{17}$ The film's (mis)appropriations of the science fiction genre remain ironic and its plot resolutions unconvincing. The shantytowndwellers are raised too hastily from extreme marginalization to the front line 
of the nation's defense, and the aliens are not vanquished by sophisticated technology or a unified armed response, but by the dirty water and slime of the villa, which causes them to melt. There is a parodic echo here of The War of the Worlds, in which the all-powerful Martians who wreak devastation on our planet are finally killed by bacteria to which they had no immunity.

Science fiction often has recourse in this way to the deus ex machina, a plot device that brings about an artificial resolution. ${ }^{18}$ It is used with heavy irony in Estrellas, as there is no attempt to make the contrived solution seem any less implausible: the glorification of shantytown filth is fully intended to be ludicrous. Jameson argues that reflexivity may, in this manner, heighten the capacity of science fiction and utopian narratives "to confront us with our incapacity to imagine Utopia." 19 Reflexive texts, he suggests, often express the difficulties of their own production of utopian narratives in the deliberately "homemade qualities" and "amateurishness" of their constructions: "That very lack of ontological density for the reader, that very artifice and unbelievability which are surely disastrous in most realistic novels, is here an unexpected source of strength." ${ }^{20}$ Estrellas makes use of such strategies for an identical purpose: to confront us with our inability to believe that the shantytown could be the site of the overthrow of a technologically superior race, or indeed a symbol of national integration.

Our sense of the anachronistic reveals to us the extent to which we are conditioned to expect a very narrow range of themes and subjects (poverty, misery, violence) in a film located in a shantytown. The shantytown is most often portrayed in cinema and other media as a lawless, impoverished place trapped in underdevelopment, a yet-to-be-modernized enclave within an otherwise modernized city. This is certainly what Alan Parker was looking for when he came to the villa in search of a historical location for his film Evita (1996). However, as Julio relates, Parker left disappointed: there were just too many television aerials. Indeed, far from representing a premodern enclave, Julio's villa is a place that participates actively in multiple exchanges across its borders. The film's treatment of these exchanges uncovers something of the complex relationship between center and periphery that is often elided in historicist accounts of modernity. Julio is at pains to construct the relationship between the villeros and First World filmmakers as one of symbiosis. "Nos necesitamos mútuamente" (We have a mutual need for each other), he insists: if villeros lack technology and need work, filmmakers need authentic-looking extras and locations, as well as a good supply of cheap labor for production assistance. In effect, Julio's enterprise mimics the imperial distribution of labor, according to which Europe supplied technology 
and supervision, and the colonies supplied the workforce. The discourse of mutuality — and indeed, by the end of the film it would be difficult to say who is exploiting whom-draws our attention to Europe's continued reliance on the Third World, whether in the form of human labor or of "authentic" backdrops for period dramas and social-conscience films.

The consistent positioning of the villa in Estrellas as integral to modernizing processes rather than lagging behind them suggests a very different understanding of modernity than the linear one that underpins colonial and neocolonial discourses. It is one that resonates instead with Fernando Coronil's Occidentalist perspective. Coronil maintains that modernity does not first originate in Europe, then to be imposed upon the rest of the world; it is produced by the relationship between Europe and its colonies, in which the colonies provided much of the wealth and means of expansion that underpinned modernity. In this vein, Coronil criticizes Michael Taussig's The Devil and Commodity Fetishism in South America (1980) for constructing Colombian peasants and Bolivian miners as emblems of a precapitalist world, living in a place beyond the reach of commodity fetishism. Although Taussig's intention is to turn anthropology's gaze back toward Western culture and to defamiliarize capitalism, Coronil charges him with ignoring the fact that "these peasants are in fact coauthors of the history of Western capitalism and should be seen as part of the Western world. Just as their slave ancestors contributed to the making of the Occident, these peasants are engaged today in reproducing Western capitalism." ${ }^{11}$ Estrellas, by contrast, is most attentive to the complex dynamics of such cultural and economic exchanges. The villa is not presented as a self-contained, precapitalist society that might guide the film's viewers to an alternative way of life and thereby defamiliarize the workings of capitalism, but one that is linked in multiple ways to the city, nation, and world beyond its borders. It is an already mediatized place whose own ideas of identity and authenticity have been coauthored with discourses emanating from other centers. Rather than simply being positioned at the receiving end of Western modernization, the villa in Estrellas is shown to have an impact on forms of consumption in the West, fulfilling and creating further demand for manufactured "authenticity" and for (often formulaic) films about poverty and violence in the developing world.

In this way, the film disrupts a linear understanding of modernity as a phenomenon rolled out from the center to the periphery, sustained by the ever-increasing expansion of capitalism that radiates out from the West to further and further reaches of the world. It is this conception that Dipesh Chakrabarty finds embodied in historicism, as the assumed existence of a 
single, homogeneous time, into which all the world's events can be fitted. It was historicism, claims Chakrabarty, "that allowed Marx to say that the 'country that is more developed industrially only shows, to the less developed, the image of its own future." 22 The "less developed" world is thereby consigned to exist anachronistically as a relic of the past, already superseded by the modernized world: overlooked by it, an ugly by-product of it, or a passive receptor of its goods.

This is very much the vision that informs Jameson's historicist critique of postmodernity and capitalism. Postmodernity for Jameson is synonymous with the global triumph of capitalism, which has swept away all precapitalist "enclaves" and ensured "their utter assimilation into capitalism itself." ${ }^{33}$ As a result, "no society has ever been so standardized as this one, and ... the stream of human, social, and historical temporality has never flowed quite so homogeneously." ${ }^{24}$ To write, as Jameson does, of a "lag" in economies, and the presence of "archaic" elements as hangovers of a premodern past, ${ }^{25}$ is to inscribe world history within a single, unified trajectory. Postmodernity emerges as the future to which all economies are heading, as the postmodern is characterized "as a situation in which the survival, the residue, the holdover, the archaic, has finally been swept away without a trace." ${ }^{26}$ If, as Chakrabarty observes, "From Mandel to Jameson, nobody sees "late capitalism' as a system whose driving engine may be in the third world," ${ }^{27}$ Estrellas affords us a glimpse of the crucial role of the periphery in the construction of modernity, and complicates any division of the world's places into archaic or contemporary. The villa full of television aerials and its image-savvy inhabitants refuse to be positioned as archaic or uniformly undeveloped for the purposes of historical dramas or colorful social problem films. The "anachronism" of making a science fiction film in an Argentine shantytown confronts us with a discourse that continues to inscribe the histories of nations within the homogeneous time of colonialism and modernity.

\section{Cóndor Crux and the Polytemporality of Technology}

Darwin City, 2068. The world has been plunged into darkness and its citizens corralled into domed urban enclaves. The absolute power wielded by the Corporación Gloria Mundi has obliterated all hopes for a new future; that is, "hasta que un día, alguien decidió que era tiempo de reciclar" (until one day, someone decided that it was time for some recycling).

Recycling the past in Cóndor Crux, la leyenda provides a way to reimagine 


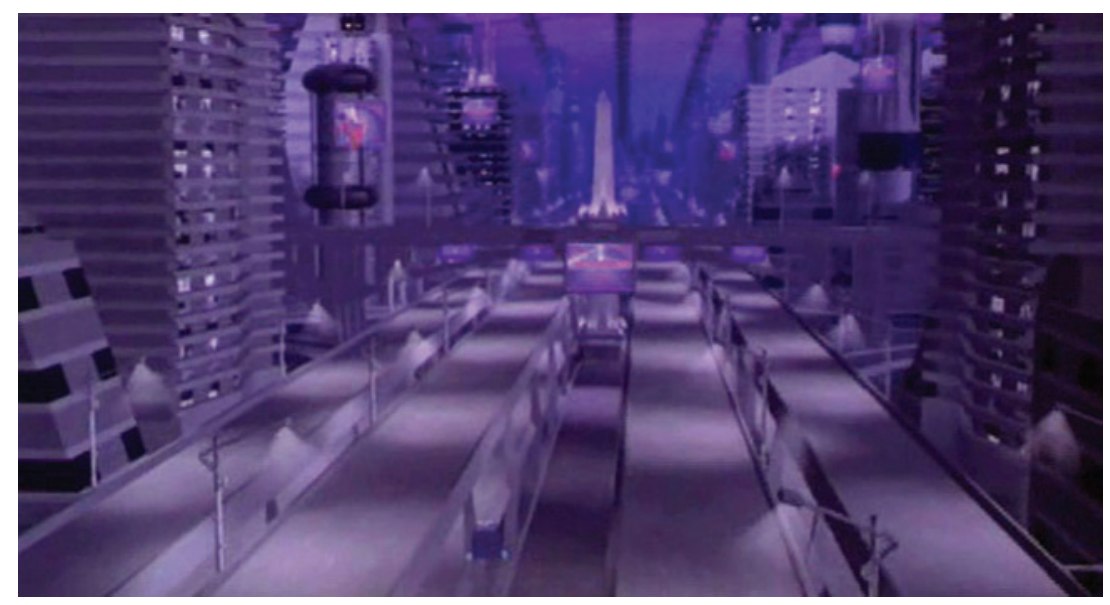

Fig. 16. Cóndor Crux, la leyenda (Juan Pablo Buscarini and Swan Glecer, 200o)

the future when utopian visions are unthinkable. Ciudad Darwin, the seat of the technocratic regime, is an artificial bubble isolated from the rest of Latin America and severed from the continent's indigenous roots. That the city is a futuristic vision of Buenos Aires is abundantly clear from its position on the map in the opening sequence of the film, and an early shot of the Obelisk from an airborne police patrol unit as it flies down the Avenida 9 de Julio (see fig. 16). Produced at the end of the neoliberal I990s, the film can be read as a warning of the dangers of the acceleration of Buenos Aires and Argentina away from the rest of the continent. The Corporationreminiscent of the powerful multinationals that gained monopolies over Argentine industries as a result of Menem's unchecked neoliberalism-has acquired control over all media and satellite transmission. The film's 3-D animation techniques emphasize the immersion of its citizens in a world of artificial light and advanced technology: they enhance the reflective qualities of different surfaces, including human skin and the spectacles or visors worn by the characters, lit by glows and flashes in a series of close, claustrophobic interactions with screens and other technological devices.

Cóndor Crux, the banished hero, must embrace the destiny written for him by the gods before returning to liberate his city from the evil grip of its dictator Phizar, and to reintegrate the ultramodernized Ciudad Darwin (Buenos Aires) with traditional, rural, and indigenous Latin America. If the city's inhabitants of have been subjected for decades to the lie that life anywhere else is impossible, the film attempts to show how much they need 
the more traditional skills and knowledge of indigenous cultures in order to break free from the triple grip of economic privatization, political repression, and navel-gazing psychoanalysis. The first time we see Crux, he is lying on a couch talking about his difficult relationship with his father to "Freud-Man," a virtual pocket psychoanalyst who travels everywhere with him. This "programa de estabilización de emociones" (emotion-stabilization program) is used widely in Darwin, we are told; "Freud-Man" often tries to check Crux's ambitions in the name of personal safety, resisting changes to the status quo and becoming more of a tool of political control than of psychological therapy. Cóndor Crux paints a picture of a Buenos Aires that is too narcissistic to think beyond the private sphere of emotions, and too obsessed with its Oedipal complexes to recognize its real fathers in the continent beyond the city's reaches, or to channel filial rebellion more creatively toward the goal of social revolution.

Crux's journey begins in a settlement in the Amazon jungle, which he later discovers to be none other than the mythical El Dorado. Traveling onward with Sonia (the guardian of El Dorado) and Junco (an indigenous boy from the village), Crux finds temporary relief from his pursuers in the sacred city of Machu Picchu, where he undergoes a kind of spiritual fusion with a pre-Hispanic heritage that binds him to his divine destiny. In this scene, Crux is raised from the ground to face his mythical self, painted in the form of a condor on the roof of the Incan temple. From above, we see him superimposed on a circular design etched into the temple floor that evokes one of the calendars widely used in Aztec, Mayan, and Incan civilizations. In the esoteric sequence that follows, pre-Hispanic motifs are briefly tattooed against a vibrant collage (see fig. 17). Past, present, and future merge as Incan statues acquire the highly reflective, shiny surfaces of digital modeling, ancient symbols are superimposed on the faces of the film's characters, and CGI animation mimics the shifting patterns of the kaleidoscope, a very early precursor in the generation of moving images.

The flamboyant virtuosity of this sequence takes us out of the temporal and spatial coordinates of the film's diegesis, and in fact far beyond any accurate understanding of history and geography. The animal forms that emerge from the kaleidoscope are drawn quite indiscriminately from Aztec, Mayan, and Incan symbology. The condor belongs to Andean mythology and was also an important Incan symbol, but the monkey shown is not an Incan one but the Mayan dancing monkey, while the concentric circles and parallel lines of the birds resemble Aztec renderings. This pre-Hispanic potpourri completely ignores historical context in its evocation of pure "pastness." We 


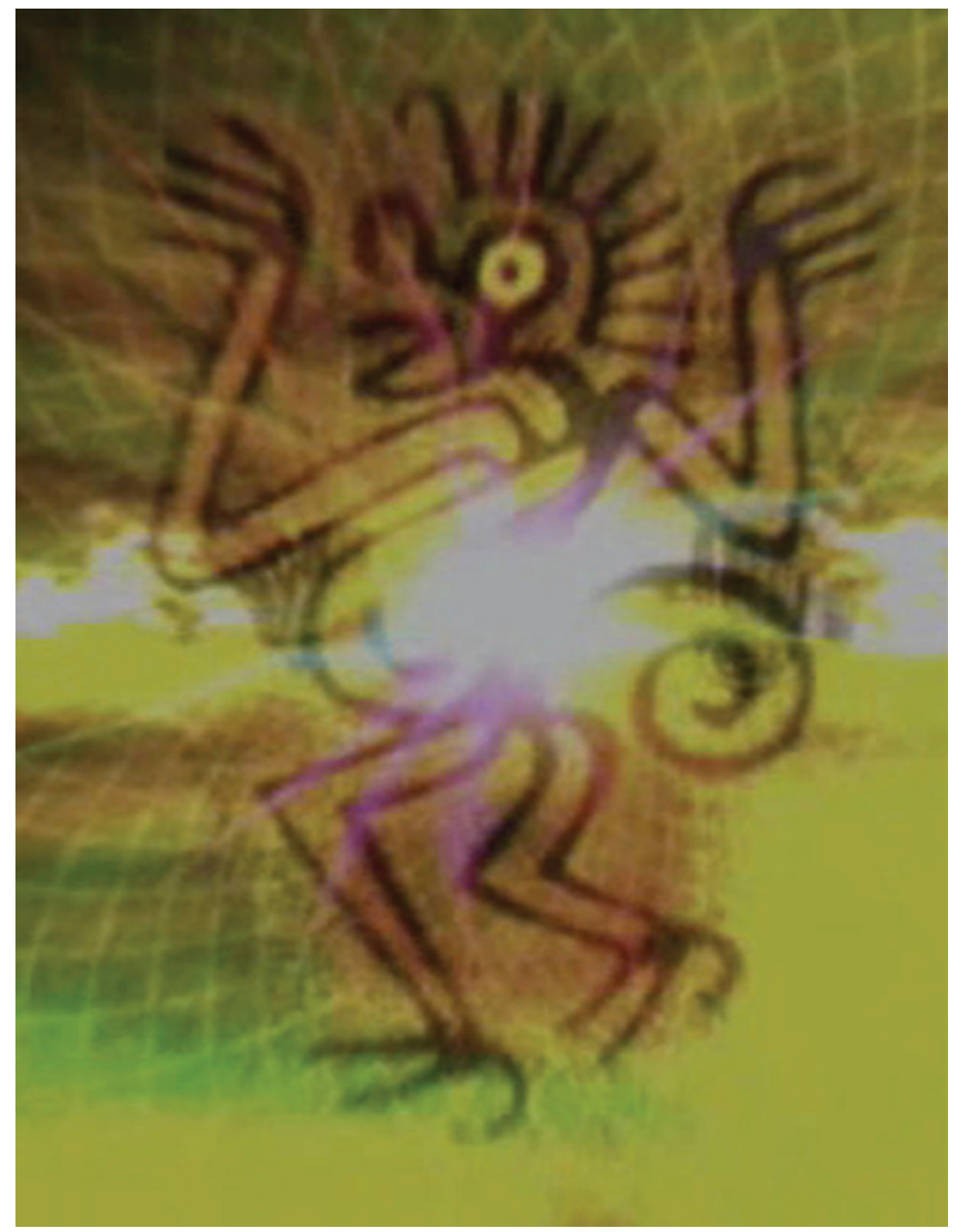

Fig. 17. Cóndor Crux, la leyenda (Juan Pablo Buscarini and Swan Glecer, 200o) 
would seem to be thoroughly immersed in the kind of postmodern intertextuality Jameson decries as "the operator of a new connotation of 'pastness' and pseudo historical depth, in which the history of aesthetic styles displaces 'real' history." 28

In an even greater insult to history, of course, the fusion sequence references a past that is patently not Crux's at all, whose white European features-like those of the majority of inhabitants of current-day Buenos Aires - contrast strongly with the much darker skin of his new indigenous companions, with whom he appears to share little racial heritage. The film's blatant ahistoricism is key, however, to its utopian projection of a future integration that overcomes the racial and cultural divisions of the past. The deliberately eclectic fusion sequence has the effect of creating a kind of panAmerican symbology in which all the forces of pre-Conquest America are concentrated to bring Buenos Aires back to an encounter with the past, and to the rest of the continent, from which it had severed all ties. The ritual Crux undergoes binds the human to the divine, the individual to the sweep of History, and the present to its mythical origins. It supplements and intersects the "machine time" or "clock time" of modernity that, as Adam reminds us, "is a time cut loose from the temporality of body, nature and the cosmos, from context-bound being and spiritual existence." ${ }^{29}$ Invoking the temporalities of nature and myth is one way in which the film disrupts the homogeneous, linear time of modernity. It combats a vision of Latin America as a collection of separate enclaves, isolated from each other by the different trajectories they have taken in relation to tradition and modernization. It also performs an encounter between two different temporalities, between historical time and mythical time, in such a way that they are shown to interpenetrate, and the latter is not dismissed as more archaic than the other.

Like many science fiction films, Cóndor Crux often stages the victory of the ancient or apparently obsolete over the highly advanced and modernized. The rebels' call to revolution is made with the aid of an old, disused satellite. When Crux and his father discover that the transmission of the vital code to unlock it has failed and all seems lost, the system is activated by the simple sequence played by the Indian boy on an ocarina. The eight moving discs on the control panel throb and gyrate to the melody played on the little eight-holed instrument, just as - metaphorically — the present and future of Ciudad Darwin now dance to the tune of the past, its redemption written in ancient prophecy. For his triumphant flight back to liberate Ciudad Darwin, Crux has no option but to borrow an eighty-year-old Antonov, a heavy-duty Soviet transport plane first flown in the 1980 os. $^{30}$ The plane serves him well 
until it runs out of fuel; he then descends gloriously into the dome, dodging Phizar's missiles, precariously perched on an old hang glider he finds in the plane. The decisive blow that kills the evil technocrat is struck with Sonia's rudimentary jungle spear.

But Cóndor Crux does not-in the Romantic vein of much science fiction-simply extol the ancient and the natural in place of the technologically advanced: it reminds us of the extent to which new technology draws on the old without superseding it, in a manner that complicates any linear model of development. The polytemporality of technology is brought to the fore in the many machines in the film that are shown to mimic the inventions of nature, such as the fabric of Crux's hang glider, stretched into the form of a condor's wings, or even the Antonov, code-named "Condor" by NATO. ${ }^{31}$ It is also strikingly demonstrated in a visual analogy that links Ciudad Darwin's most advanced aeronautical design with Incan engineering. As Crux's aircraft lands neatly on a stone terrace at Machu Picchu, the pattern of its gray fuselage panels exactly mimics the precision-cut stonework of the Incas, even to the point of replicating the darker hues around the edging that show the effects of environmental pollution over time (see fig. I8). We notice for the first time that the aircraft's landing struts look suspiciously like the legs and feet of an animal, rendered in stone. What had appeared futuristic in its design just a few frames ago now seems to be integral to the architecture of the past.

This scene does not enact a return to the past, but forges a surprising point of convergence between past and present. It is precisely in relation to the simultaneous presence of the archaic and the advanced in our use of technology that Bruno Latour encourages us to consider time as a spiral rather than a line. According to this model, "The past is not surpassed but revisited, repeated, surrounded, protected, recombined, reinterpreted and reshuffled," and elements that appear far from each other along the line traced by the spiral may turn out to be very close when the loops are compared. ${ }^{32}$ This understanding of temporality complicates the use of categories such as "archaic" or "advanced," as "every cohort of contemporary elements may bring together elements from all times." Michel Serres, arguing a similar point, uses the example of a car as "a disparate aggregate of scientific and technical solutions dating from different periods." 33

In Jameson's account of the homogenizing effects of postmodernity, he is careful to state that these are at present largely to be observed in the West. ${ }^{34}$ The remnants of traditional or alternative forms of society in other parts of the world are fast disappearing, however, and will soon—in his view—be 


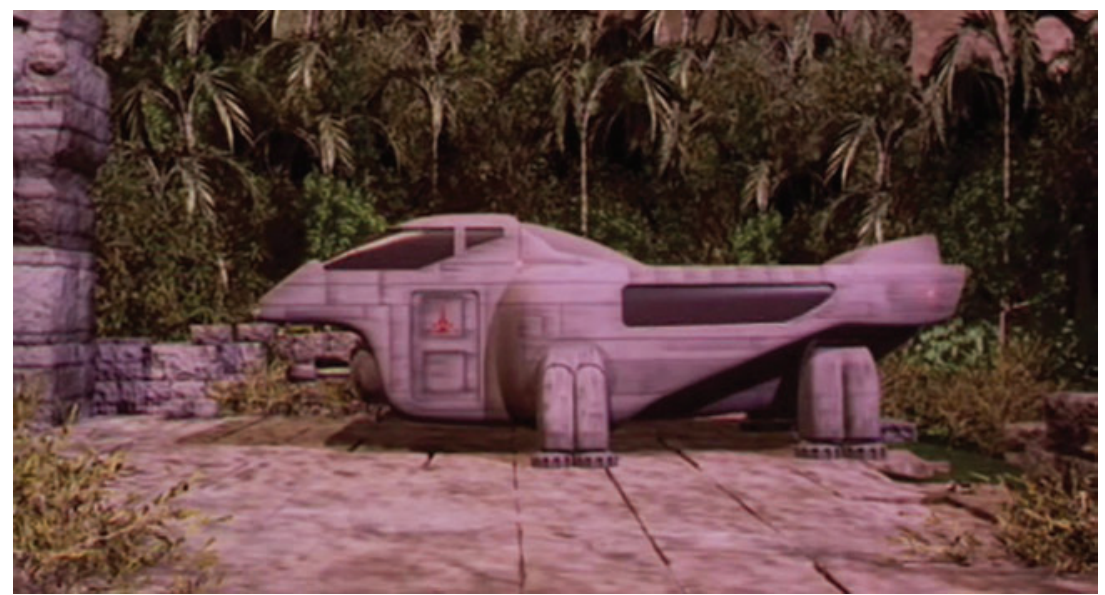

Fig. I8. Cóndor Crux, la leyenda (Juan Pablo Buscarini and Swan Glecer, 200o)

erased in the inexorable march of capitalism and modernization toward the very limits of expansion. Although Cóndor Crux repeats the colonial desire to find what the self lacks in other, more "primitive" cultures, it challenges the historicist underpinning of colonial (and here, Jamesonian) discourse by imagining an alternative in which the ethnographic other is not a relic of the past but fully coeval with the present. In line with Chakrabarty, Bliss Cua Lim describes the processes by which supernatural beliefs or other "premodern" cultural differences are "temporally managed" in discourses ranging from sixteenth-century colonial missionary accounts to ethnographic cinema, "by being positioned as already known and surmounted precursors, not something disturbing that persists alongside and within the modern but as relics of superseded chronological antecedents. ${ }^{35}$ By contrast, Sonia's spiritual beliefs in Cóndor Crux may be "traditional" in the sense that they predate modernity, but nowhere in the film are they positioned as outmoded. Pre-Hispanic gods are not relegated to the past but play a vital cultural and political role in the present.

It is entirely fitting that polytemporality should be one of the major themes of the first 3-D animated film to be made in Argentina, following hard on the heels of Pixar's Toy Story (1995), the world's first feature-length 3-D animation. In our day, 3-D animation is arguably the mode of film production that combines the most archaic forms of art and technology with the most advanced. The complex algorithms that underpin the computerized creation of 3-D effects typically follow earlier stages in which characters 
are sketched by hand or molded out of clay. Cóndor Crux made extensive use of traditional storyboards and then frame-by-frame line drawings using pencil and paper to produce a 2-D animation. 3-D effects were only added later, in order to give the appearance of live action rather than computergenerated imagery. Significantly, the filmmakers do this not simply by reconstructing the shading and shadows that make shapes and textures more realistic, but by evoking the older technology of analog filmmaking. Motion blur is introduced to mimic a camera panning at speed, backgrounds are blurred to imitate a camera's use of shallow focus, and when Crux's aircraft judders out of control, images are shaken rapidly on a vertical axis as if the camera cannot be held steady. As Lev Manovich observes, the quest for realism in 3-D computer animation involves not only the simulation of real objects and environments, but also "the simulation of the codes of traditional cinematography." 36 Many techniques used in Cóndor Crux are clear examples of "digital mimicry," the term Philip Rosen uses to refer to digital cinema's capacity to imitate "preexisting compositional forms of imagery," such as photography or analog film. ${ }^{37}$

What would it mean to call this film, or any film, "contemporary," if "superseded" technologies__analog filmmaking and line drawings_ are essential to the film's most advanced techniques? Firmly inscribed in the film's production process and its aesthetic design is the same polytemporality that is emphasized in its narrative, and that Serres and Latour understand to be characteristic of all human experience of technology. Indeed, for Manovich, the process of image construction in digital cinema no longer permits a distinction to be made between cinema and animation. ${ }^{38}$ The history of the moving image thus "makes a full circle". ${ }^{39}$ having previously adopted the guise of "a simple recording of an already existing reality," cinema now returns to its roots in the manual techniques of animation, deploying a range of special effects that had been pushed to the margins for the greater part of the twentieth century. ${ }^{40}$

In Cóndor Crux, the rebels' principal message, broadcast to every astounded citizen, is that, despite the lies they have been told, "fuera de Darwin .. . un maravilloso continente aún vive" (beyond Darwin, a marvelous continent lives on). At the end of the film, a new Ciudad Darwin is built that replaces the perpetual night, artificiality, and geometric architecture of the old city with sunlight, greenery, and voluptuous curves. The narrator whose voice we heard at the beginning of the film is revealed as the indigenous boy Junco, now a wizened elder, recounting the history of Darwin to a group of young children. In a final gesture of regional integration-and 
utter disrespect for the laws of natural habitats—an Andean condor flies majestically across the cityscape as it recedes from our view. Cóndor Crux's crimes against history (and geography) may be flagrant, but the film's primary intent is precisely to question any linear model of temporality that assumes that the past is superseded by the present and the future.

Latour attributes this linear time of supersession to an invention of modernity. As he states, "The moderns have a peculiar propensity for understanding time that passes as if it were really abolishing the past behind it," considering themselves divided from the Middle Ages by "epistemic ruptures so radical that nothing of that past survives in them." ${ }^{41}$ This produces a sense of time "as an irreversible arrow," which is also the time of capitalization and progress. ${ }^{42}$ Against this understanding of time, Estrellas and Cóndor Crux — in common with many Argentine science fiction films-encourage us to view technology and discourses as "polychronic," to use Serres's term, and every historical era as "likewise multitemporal, simultaneously drawing from the obsolete, the contemporary, and the futuristic." ${ }^{43}$

The reflexive and ludic exploration in Estrellas of the conventions of the science fiction genre challenges linear models of development by positioning the villa as a coauthor of Western modernity rather than simply a place overlooked by modernization, an ugly by-product of it, or a passive receptor of its goods. By performing a convergence between historical time and mythical time, Cóndor Crux demonstrates the extent to which the evolution of human culture and technology is more topological than chronological, looping back to incorporate the apparently antiquated and folding in on itself to bring past and future into sudden proximity. If this perspective appears ahistorical, then—as Serres suggests—our theory of history may be based on an "inadequate and naïve" understanding of time. ${ }^{44}$ Both Estrellas and Cóndor Crux dramatize a conflict or an exchange between different ways of organizing time, each of which is fully capable of producing meaning. They give the lie to the homogeneous, empty time of historicism that, as Chakrabarty observes, "is what made modernity or capitalism look not simply global but rather as something that became global over time, by originating in one place (Europe) and then spreading outside it." ${ }^{55}$ By defamiliarizing, deconstructing, and reconfiguring stories of capitalist development and technological advance, both films expose the illusion of inevitability in which such trajectories are shrouded. They respond to Benjamin's call for a critique of "homogeneous, empty time" as the crucial basis for a critique of the notion of progress, allowing us to imagine different ways in which the history of modernity and capitalism may be told, or alternative stories that may yet unfold. 


\section{Retrofuturism and Reflexivity: The Construction of} Cinematic Time in La antena and La sonámbula

In his discussion of utopia and science fiction in Archaeologies of the Future, Jameson observes the "seeming extinction" of the classical forms of utopian writing and "the emergence of newer, more reflexive forms." ${ }^{36}$ Rather than offering specific "blueprints" of future societies, imagining and defending the value of invented social institutions, these texts center on "the possibility of their own production, in the interrogation of the dilemmas involved in their own emergence as utopian texts." ${ }^{\prime 7}$ Most persuasively, Jameson argues that this reflexive turn allows us to glimpse the "deepest vocation" of utopian narratives: not to bring forth convincing and coherent new worlds, but to confront us precisely with their inability to do so. This failure should not be understood as the inadequacy of any individual's vision but, instead, "as the result of the systemic, cultural and ideological closure of which we are all in one way or another prisoners." ${ }^{48}$ Utopian narrative is at its most utopian, Jameson contends, when it demonstrates to us our imprisonment within the present (ideological) moment.

The two Argentine science fiction films discussed in this section pursue a highly reflexive approach to their construction of alternative worlds. At first sight, both films seem to set out the familiar science fiction scenario of the evil dictator who maintains power through advanced technologies of surveillance and psychological control. The hapless citizens of La antena (Esteban Sapir, 2007) are kept in thrall to their silent, monochrome existence by Señor TV's manipulation of television's hypnotic power, while in La sonámbula (Fernando Spiner, 1998), the state uses filmed recordings of individuals' dreams and memories to assign identities to the three hundred thousand of the city's inhabitants who are suffering from amnesia after a chemical explosion triggered by the government. However, as I will suggest, these films' primary interest is in the construction of visual technologies as the tools of utopian imagination rather than the servants of dystopian terror.

The experiments of both films with generic convention and their fabrication of extremely heterogeneous visual styles continually emphasize what Jameson refers to as "the constructed, invented, artificial nature of SF as a genre." ${ }^{49}$ The fairy-tale and comic-book aesthetics of La antena clearly draw attention to the artifice of its utopian narrative; in La sonámbula, as we will see, the insertion of sequences carrying a pseudodocumentary charge points to the impossibility of sustaining a vision of an ultramodernized, futuristic Buenos Aires. In this manner, the films could be argued consciously to reiterate the failure of the utopian imagination, the crucial political contribu- 
tion that Jameson ascribes to science fiction since the late twentieth century. Although they are thoroughly reflexive, however, neither La antena nor $L a$ sonámbula ultimately constructs a utopian vision that fails in the way that Jameson describes. Indeed, as I will show, they locate utopian potential precisely within the power of cinema itself as a visual technology, to liberate as much as to oppress, to reshape temporalities and bring about encounters between alternative temporalities, and to free us from the deception that our present moment can be located at a point within a homogeneous, linear course of historical inevitability. These films' reflexive exploration of the construction and manipulation of time in cinema brings some important nuances to Jameson's account of postmodern science fiction; it also allows us to probe some of the tensions that emerge more generally in his approach to postmodernism.

\section{Retrofuturism in La antena: Recycling as a Critique of Capitalist Consumption}

For Jameson, postmodernism's abandonment of a properly historical perspective-which would seek to understand causality and connections and recognize the events and processes that separate the present from the past-is everywhere evident in "the random cannibalization of all the styles of the past, the play of random stylistic allusion." ${ }^{50}$ It is this appropriation of past styles with disregard for their "content," or their placing within broader historical narratives, that in his view erodes postmodernism's potential for a serious political critique of the present. Somewhat unexpectedly, therefore, Jameson does reserve a creative and critical role for "collage" as a principle of organization in postmodern science fiction, defined as "the bringing into precarious coexistence of elements drawn from very different sources and contexts, elements which derive for the most part from older literary models and which amount to broken fragments of the outworn older genres or of the newer productions of the media (for example, comic strips)." ${ }^{11}$ In the best examples of this technique, Jameson suggests, such collage "operates a kind of foregrounding of the older generic models themselves, a kind of estrangement effect practiced on our own generic receptivity." ${ }^{2}$

In the highly retrofuturistic La antena, an aesthetic "cannibalization" certainly produces a flattening-out of historical relationships of the kind Jameson claims destroy all genuine sense of historicity in postmodern culture. However, the film's deliberate mixture of visual styles and genres-including comic-book styles_-produces exactly the estranging effect Jameson describes 
with respect to our response to genre and particularly, as we will see, to the history of the evolution of genre in cinema. In a way that Jameson does not appear to acknowledge as possible in his earlier discussions of postmodern culture, in which he decries our era's inability to imagine alternatives to the capitalist present, the collage techniques of La antena become crucial to the film's subversion of the linear, irreversible time of capitalist progress, and to its promotion of cinema as an effective tool for reshaping linear temporalities and critiquing such notions of progress.

Styles from the I930s and I940s predominate in La antena's costumes and its studio mock-ups of city streets, but the existence of forms of telekinetic energy unknown to our science thrusts us into the future, or (more likely) into an alternative past. In this heterotemporal world, old inventions, like the manual typewriter, become vital parts of new and unfamiliar machines, and a 1930 F Ford is fitted with a contemporary car alarm. Most strikingand entertaining - in the film is the evocation of older styles of filmmaking, principally silent cinema, expressionism, and film noir. Critics have identified a raft of allusions to early films, including to The Cabinet of Dr. Caligari (Robert Wiene, 1920), Metropolis (Fritz Lang, 1927), and Man with a Movie Camera (Dziga Vertov, 1929). ${ }^{53}$ More generally, the film makes ample use of formal devices commonly used in early films, such as irises and screen wipes. The fairy-tale mode of narration and the conspicuous artificiality of acting and effects-featuring obviously synthetic teardrops and snowflakesfurther dislodge any clear temporal framework for the film. There is no interest here in the particular historical processes that might have led to the construction of modernity in Buenos Aires or any other city.

The film would seem to epitomize the "waning of historicity" Jameson finds at the root of postmodernism's eclectic recycling of the icons and symbols of the past. However, historical artifacts and styles are by no means relegated here to the status of mere decoration or connotation: they do not simply float free from their referents but are consciously redeployed for a particular diegetic purpose. For example, the use of early-cinema-style intertitles is justified, as the evil Señor TV has robbed the citizens of their voices, leaving them mute; the undisguised use of scale models, two-dimensional sets, and black-and-white film stock depict a city stripped of its creativity and forced into a monochrome existence of perpetual winter. This aesthetic of refunctioning to which the film subscribes is, as we will see, central to its critique of capitalism.

Like Metropolis, La antena presents the viewer with a compelling visualization of the mechanics of capitalist labor and production, and the cycles 
of labor and consumption that yoke workers to the system. Food can only be bought in the form of identical, factory-produced biscuits that come in a large box stamped with "Alimentos TV" (TV Food). The purpose of television is to stimulate greater consumption of these biscuits through a kind of hypnosis. Toward the end, La antena suddenly reveals to us the cruel machinery that makes ordinary citizens unwitting accomplices in their own subjugation, as both the chief resource and the major consumers in a vast biotechnological energy cycle. In an arresting sequence, we see their words sucked into a vast satellite receiver and smashed by pistons before being dropped into a giant kneading machine, out of which comes the dough to bake the "Alimentos TV" biscuits, which proceed smoothly along conveyor belts to be packaged up for purchase. It is a chilling rendition of Marx's account of the labor-consumption cycle in capitalism, in which food is converted into energy for labor, which is then converted into money to buy more food. ${ }^{54}$

Although clearly indebted to Lang's depiction of a dehumanized modernity in Metropolis, Sapir's film updates that vision by referencing our twenty-first-century awareness of capitalism's fragility, and its reliance on finite resources. The voices stolen from the citizens have powered the system successfully, but now even more energy is needed. And in the end, the system, so apparently implacable, comes to a grinding halt at the transmission of an alternative voice, that of a little boy who owns one of the two voices left among the population and the only one that is not under the domination of Señor TV. La antena presents us with a utopian vision in which capitalism may seem to be ingrained in the bedrock of society, but its greedy exploitation of finite resources and its reliance on the blind complicity of those it exploits render it fragile, allowing for the possible advent of alternatives to the system.

Recycling and repair become the means by which La antena presents a form of resistance to the logic of capitalist consumption. The word "reparar" (to repair) acquires a special importance in the film. Ana's father works in a television repair workshop; when he discovers the existence of an old satellite transmitter, he is told that he needs to "repararlo" (repair it), and along the way, his marriage is also "reparado" (repaired), just as the torn family photograph is stuck back together with sticky tape. The characters continually make use of old inventions to fashion the new, or restore to full function and meaning what had been broken and abandoned. It is the rehabilitation of an old, abandoned satellite that destroys the regime's total power. To recycle, repair, and refunction is to break the cycle of production and consumption 
that depends on finite resources. "La imaginación ha salvado a los hombres" (imagination has been the savior of men) is the inscription on a framed drawing Ana's grandfather was given by his mother, and La antena remains confident that there is no risk that human inventiveness might ever run out.

My reading of La antena lends a much more positive meaning to the concept of recycling than Giuliana Bruno does in her influential analysis of Blade Runner (Ridley Scott, 1982), which draws extensively on Jameson in its discussion of the film's representation of time and space in postmodernity. Like La antena, Blade Runner dramatizes the increasing commodification of life under advanced capitalism. In Scott's Los Angeles, glittering urban temples, futuristic airmobiles, and latest-generation robots cohabit with urban devastation, pollution, and overcrowding, as an ever-present reminder of the cost of capitalist advance. For Bruno, the film's aesthetic of recycling and its resort to pastiche expose the logic that binds late capitalism and postindustrialism to the continual production of waste. ${ }^{55}$ Recycling in $L a$ antena, however, does not demonstrate this process of "wearing out, waste" 56 that Bruno finds to be central to Blade Runner's own retrofuturistic aesthetic: instead, it refers to a much more active process by which the obsolete or broken-down is repaired or refunctioned for a new and meaningful use. By extension, technology in La antena is not—as it is in Blade Runner-simply a dehumanizing force, continually threatening the boundaries between the human and the machinic through the production of simulacra. Instead, the use of technology is also quintessential to human creativity. Tools and machines may be used to alienate, exploit, and dehumanize for selfish gain, but they may also be used to redeem, restore, and rebuild relationships and communities. Blade Runner cannot imagine any real liberation from the capitalist dystopia it presents: Deckard's flight from the city with Rachael is likely to afford them only a momentary respite before they are hunted down. In La antena, human resourcefulness triumphs, making use of what has been discarded and superseded to overthrow the regime.

Nowhere is the film's positive vision of recycling and repair more evident than in its extensive citations of other films and styles, which cannot be understood as a mere substitute for real creativity. In La antena, the past is salvaged and put to new use in the composition of a distinctively original visual language. The film returns us to a specific moment in the history of cinema in the late I920s and 1930s, just prior to the advent of synchronized sound, which was a significant factor in the explosive growth of Hollywood into one of the world's most powerful cultural and commercial enterprises. Sapir acknowledges that both La antena and his earlier feature-length production, 
Picado fino (1996), were inspired by silent film; he pays homage in this way to the richness of cinematic language that was eroded, in his view, by the introduction of sound and the star system in film. From that point, cinema became a series of "historias literarias filmadas, en imágenes explicadas desde la palabra" (filmed literary texts, images defined with words). ${ }^{57}$ By contrast, La antena attempts to forge a more dynamic relationship between the visual and the verbal. Evoking the intertitles of silent film, words in La antena become fully part of the mise-en-scène and are animated with great playfulness, appearing and disappearing, or moving across the screen, in close interaction with the characters. Words may follow a character's movement, emerge from opening hands, or be partially erased by hand movements; in one shot, the smoke ring from Señor TV's cigar floats upward to form the missing letter $o$ in a word; in another, two fingers held up supply the $v$ of "voz" (voice). It is often as if the words are preceded by a gesture or an image that then gives rise to their possibility, reversing the usual relationship Sapir notes in classic realist cinema, in which images are subordinated to a preestablished narrative.

La antena thus returns to a moment before the sheer virtuosity of early film innovation was lost with the invention of synchronized sound, and its much greater commercial possibilities. The film's rich, hybrid, and playful aesthetic reveals the impoverishment behind the illusion of diversity and choice in our contemporary media society. As Sapir suggests,

Estamos inmersos en un mundo puramente visual pero irónicamente condenados a una sola forma de ver las cosas, la de los medios que nos despojan de la posibilidad de ingresar a nuestro propio mundo interior y creer en nuestra propia visión. ${ }^{58}$

We are immersed in a world that is purely visual, but ironically we are condemned to a single way of seeing things, that of the media, which robs us of the possibility of entering our own interior world and believing in our own vision.

This role of imposing a single, homogeneous vision is played in La antena by television, while the film itself deploys a whole panoply of imaginative and fantastical devices.

As James Cisneros observes, the choice of the silent-movie aesthetic in the film marks a particular contrast with television, given "the priority that televisual grammar gives to the voice." ${ }^{.9}$ For Cisneros, the major difference 
La antena establishes between its own cinematic aesthetic and that of television lies in its rejection of television's propensity for media convergence, the recycling or "remediating" of old images with the aid of new digital technologies. ${ }^{60}$ By contrast, in Cisneros's reading, La antena "points towards the divergence of distinct audiovisual practices." ${ }^{61}$ While the film undoubtedly drives a wedge between cinematic and televisual practices in many of the ways described by Cisneros, I would argue that it remains wholly committed to strategies of convergence and remediation, as theorized in the work of Richard Grusin and Henry Jenkins, among others. The acts of remediation performed in La antena constitute yet another practice of recycling the past in the film; they also draw attention to the fact that older media are not eclipsed by the introduction of new media, but merely shift in function and status, in the manner described by Jenkins. ${ }^{62}$

Although most critics have focused on the film's citations of early European cinema, it is perhaps the comic book to which the aesthetic of $L a$ antena owes most, and which it appropriates most clearly for the purposes of remediation. If the storyboard (essentially an extended comic of a film) is a device regularly used at the development stage of filmmaking, in the case of Sapir's film, it stretched to over three thousand hand-drawn images, and their construction unusually preceded the writing of the script. Many of the comic's particular modes of visuality spill over into the styles of the film itself (see fig. 19). High-contrast, black-and-white photography gives the film a cartoon look, with cutouts often replacing real actors. Dramatic use is made of the common black-and-white inversion of comic-book images, made to resemble a photographic negative; techniques of caricature and deformation are used in characterization; mise-en-scène takes priority over movement within a scene; characters and texts share the same screen as they do in a comic-book panel, with onomatopoeia used in typical comic style to plaster sound effects across the frames.

The scripting of comic-book characters into Hollywood movies (The Incredible Hulk, Men in Black, Spider-Man, Watchmen, X-Men, and V for Vendetta, to name just a few examples) has become a key instance of media convergence over the past two decades, and a familiar marketing strategy. Some of these productions have also attracted critical acclaim, however, for their innovative aesthetics: we might think of the unusual color-processing in the neonoir Sin City (Frank Miller and Roberto Rodríguez, 2005), for which the film attracted an award at Cannes, the inventive color filtration techniques of 300 (Zack Snyder, 2007), or the optical combination of matte paintings with live action in Dick Tracy (Warren Beatty, 1990). In La antena, as in these 


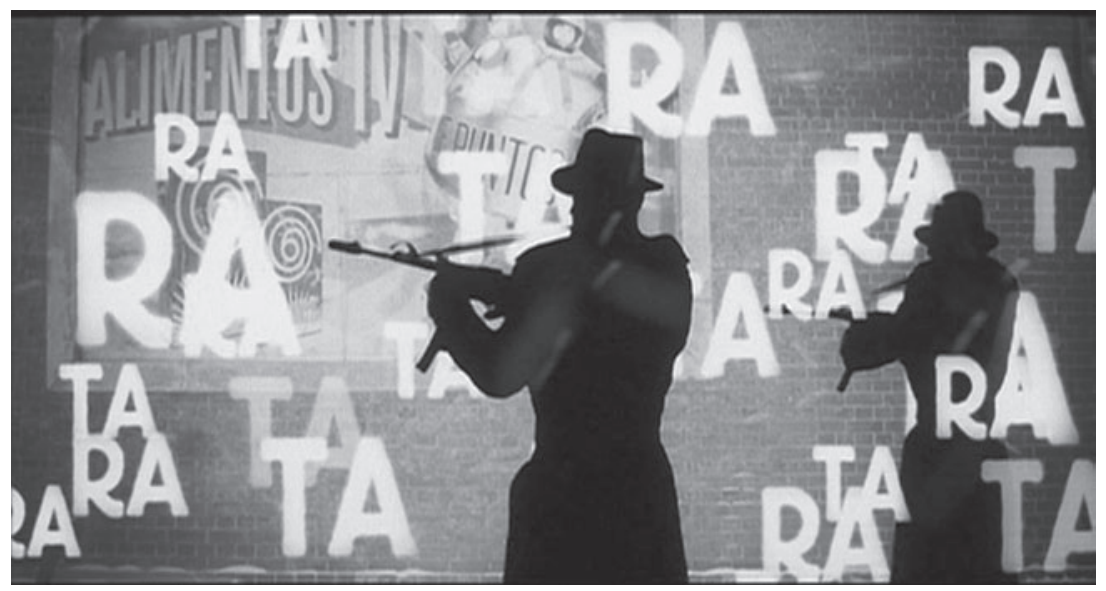

Fig. 19. La antena (Esteban Sapir, 2007)

other instances, the recycling of previous styles or those of another medium does not signal an exhaustion of aesthetics, but an opportunity to invigorate them. If media convergence in our day often seems to serve the interests of commercialism—read the book, see the film, buy the merchandise-Sapir reminds us that it can also contribute to the renovation of visual languages.

As Lisa Cartwright points out, of course, "Film has never been an autonomous medium or industry," and the relationships of the film industry with "television, consumer goods (through product tie-ins), the electrical and lighting industries, and even the make-up and fashion industries" have been well documented since the beginnings of cinema in the late nineteenth century. ${ }^{63}$ This being the case, to what extent is cinema able to critique a relationship between capitalism and the media in which it is itself fully imbricated? It can do so, La antena suggests, by countering the medias imposition of "una sola forma de ver las cosas" (a single way of seeing things), not simply by multiplying perspectives and styles - this may present only an illusion of real difference in a consumer society—but by challenging the linear concept of progress that underpins both capitalist discourses and historicist accounts of the development of cinema, which anchor styles and modes to particular sociohistorical moments and to technological resources available at any given time. In directing his postproduction team to use digital effects to mimic the use of optical devices in early cinema (mirrors, models, superimpositions), Sapir is neither paying nostalgic homage to the past nor simply constructing a blank pastiche of its styles; instead, he is introducing 
folds and cleavages into film history, unfixing filmmaking modes from their anchoring in a particular historical moment and rewriting the history of cinematic evolution according to an alternative temporality, "donde se pueda recrear un poco el cine mudo pero a través del cómic" (where silent cinema might be partly re-created through the comic medium) ${ }^{64}$

In remediation, as J. David Bolter and Richard A. Grusin suggest, we are dealing with "a genealogy of affiliations, not a linear history," as each medium continually redefines itself against others in a quest to corner cultural meaning. ${ }^{65}$ Sapir's humorous, irreverent intervention into the evolution of cinema produces a nonlinear counterhistory, replacing capitalism's self-inscription into a dynamic of supersession and obsolescence with one of recycling and repair. It is precisely its deliberate disregard for historicism that allows La antena to propose an alternative film history that is not dominated by Hollywood narrative cinema; it also permits Sapir to construct one of the few genuinely utopian visions in contemporary Argentine cinema, and one that challenges, not just the consequences, but the underlying logic of capitalism.

La sonámbula: Cinema as a Tool for Temporal Convergence

La sonámbula is set in the film's near future, in 2010 (twelve years after its release); like La antena, it presents us with a retrofuturistic vision constructed from densely layered references to classic science fiction films and a mélange of architectural styles. The fabricated skyline of Buenos Aires-again, as in La antena, an unrealistic mock-up given a grayscale, two-dimensional effect-clearly recalls the vertical cities of Metropolis and Blade Runner (see fig. 20). Spiner's science fiction, we realize, is less a vision of the future than a series of citations from an archive of past futuristic visions. Indeed, the predominance of art deco styles in many of the mocked-up external shots of Buenos Aires, ${ }^{66}$ as well as the use of certain motifs such as the mad scientist's laboratory, places the film's visual aesthetic within the "ray gun gothic" style often associated with retrofuturistic science fiction. ${ }^{67}$ This is not a future we would imagine today, but an "old future," one imagined in the past.

This vision is not applied with any historical consistency, however. Spiner readily acknowledges the influence of Brazil (Terry Gilliam, 1985) in La sonámbula's potpourri of objects and inventions from different times. ${ }^{68}$ Advanced forms of imaging are used to record and replay human dreams, while television sets, cars, and interior décor remain roughly contemporary 


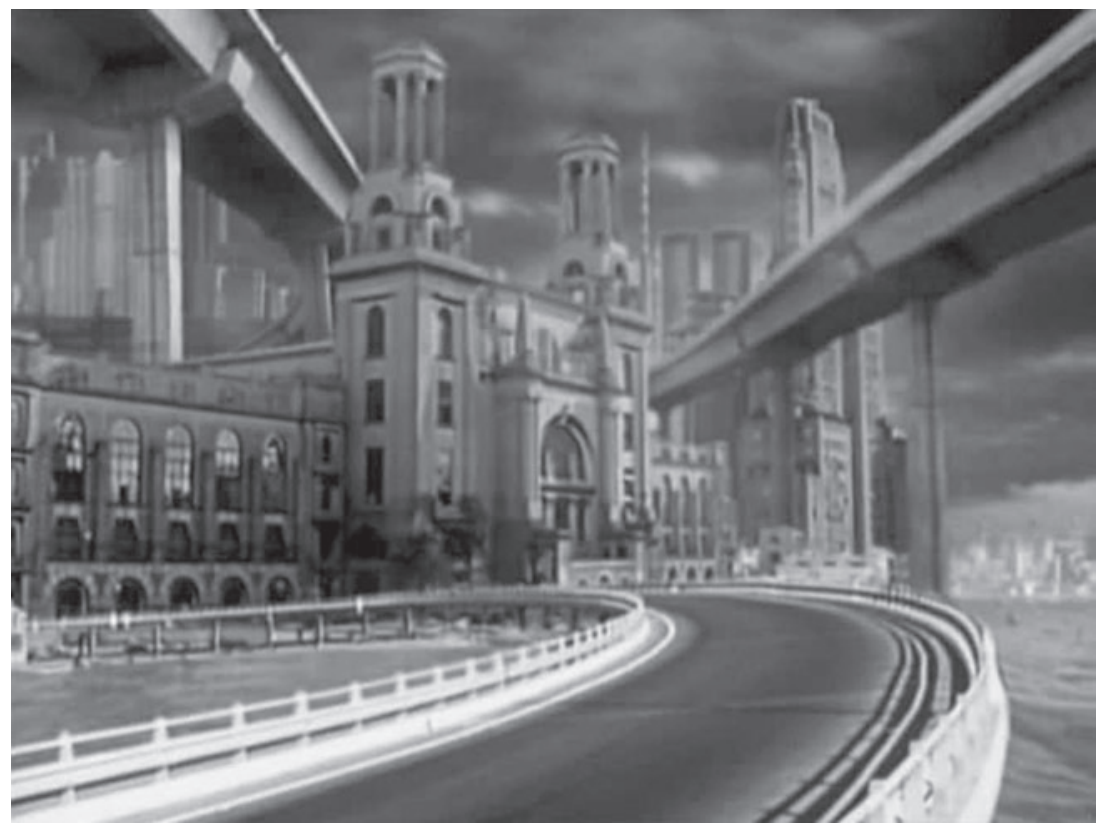

Fig. 20. La sonámbula (Fernando Spiner, 1998)

to the film's production. This dehistoricized, postmodern mash-up becomes something more than a question of style: it sets the scene for La sonámbula's reflexive exploration of the role of cinema in shaping temporality rather than simply recording the passing of time. Produced a century after cinema's invention, Spiner's film helps us to chart how conceptions of time have shifted since the late nineteenth and early twentieth centuries, moving from the modernist opposition of (objective) clock time and (subjective) psychological time to the more postmodern interest in multiple and incompatible temporalities. As I will argue, the film's deliberate failure to construct a coherent vision of the present or future is crucial to its representation of modernity as an incomplete and unsustainable fantasy, littered with the wreckage of the past. At the same time, the film draws attention to the many ways in which visual technology may both register and construct a range of temporal regimes, and encourages us to reflect on the role of cinema as a locus for the convergence of, and passage between, multiple temporalities.

Much about the film leads us to expect that its resolution will revolve around a modernist contrast between chronological (mechanized and standardized) time and the psychological time of Freudian analysis and Henri 
Bergson's durée. For Bergson, the human experience of lived time was entirely at odds with the mathematical notion of time as a series of discrete instants. Instead, what he referred to as "duration" expressed the "mutual penetration" of successive states of consciousness. ${ }^{69}$ As Elizabeth Grosz explains, within this much more dynamic conception, "The present is extended through memory into the past and through anticipation into the near future." ${ }^{70}$ Bergson's interest in a form of time that is not divisible into the identical segments of clock time forms part of a much wider exploration of private time and subjectivity in the early twentieth century, seen by many theorists as a reaction against the increasingly standardized time of labor and public life.

La sonámbula clearly references the idea of a private time existing in the interstices of chronological time, just as the film's narrative-which may have been dreamed by Eva-is framed by the tolling of church bells. Eva's vivid dream sequences, shot in rich color, are plainly marked out from the main black-and-white narrative into which they are inserted; we initially believe these sequences to represent flashbacks to a buried past, lost as a result of a chemical explosion that has afflicted three hundred thousand citizens with amnesia. Eva's dreams are recorded and analyzed by a specialist in an effort to reunite her with her past, and indeed La sonámbula insistently replays cinema's relationship with psychoanalysis, from the citations of surrealist and expressionist cinema (the unhinged Dr. Gazzar recalls the depiction of the asylum director in The Cabinet of Dr. Caligari) to the heavy use of visual apparatus — camera lenses, magnifying, recording, and playback devices—in the analysis of dreams and the recovery of the past.

However, the film ultimately resists a psychoanalytical reading in any classical sense. In the first place, it does so by interrupting the notions of psychological causality and the explanatory power of dreams and the past that underpin the conventional (Freudian) flashback. In the compulsory "rehabilitation" program run for victims of the chemical explosion, there is more than a suspicion that the state is arbitrarily inventing pasts for its amnesiac citizens, reprogramming them to accept a fabricated life-story as true. We cannot be sure if the dreams analyzed by the Centro de Investigaciones Psicobiológicos represent the surfacing of genuine remnants from the past. Moreover, although we initially assume that Eva's dreams take place in the past, we discover that most of them are predictive. The predictive dream is a device used in a number of science fiction films, among them Minority Report (Steven Spielberg, 2002) and Twelve Monkeys (Terry Gilliam, 1995); in contrast to Gilliam's film, however, in which the flash-forwards and flashbacks eventually cohere into a comprehensible narrative, no such homoge- 
neous time frame can be reconstructed for La sonámbula. At the end of the film, Kluge follows Eva into a parallel world in which she does not recognize him, and in which those characters who had borne the purple blotches of the chemical accident in the main narrative are now free of them, and vice versa. But this world is not a straightforward inversion of the other: although we appear to have returned to a pre-apocalypse world, Dr. Gazzar (now Eva's husband, and possibly also the dissident Gauna) is an impossibly younger version of himself, while the other characters appear to be the same age.

In this parallel universe, past and future have crumpled together: some things have regressed, others have advanced, while others have stood still. We cannot with any certainty decide which world, if either, has any claim to reality within the film's diegesis. Dr. Gazzar becomes convinced that if Eva wakes, it will mean the end of the world, as they depend upon her for their existence- "Si ella muere, nos morimos todos" (If she dies, we all die)—and it is certainly tempting to read the main narrative, retrospectively, as Eva's dream. What disturbs this reading is the presence of Kluge in the final scene, clearly caught up in the wrong universe, able to remember exactly the train of events that has led him here but unable to retrace his steps. There is no viewpoint in the film from which the world may be arranged coherently. The undecidability of the ending denies us the possibility of differentiating the private time of the dream from the public time of external reality. It would therefore be more accurate to identify the film's interest in temporality as primarily ontological rather than psychological: rather than pitting subjective, psychological time against objective, linear time, it presents us with the interpenetration of incompatible realities. Ursula Heise points to an analogous difference between the treatment of time in literary modernism (Woolf, Proust, Joyce) and postmodernism (Beckett, Calvino, Robbe-Grillet): if the modernist novel explores "how human perception and memory shape or distort time, and how individual temporalities are related to each other and to 'objective' time," the postmodernist novel is not interested in pursuing psychological realism in this manner. ${ }^{71}$ Instead, it enacts a "disintegration of narrator and character as recognizable and more or less stable entities, and their scattering or fragmentation across different temporal universes that can no longer be reconciled with each other, or justified by recurring to different psychological worlds." ${ }^{\prime 2}$ La sonámbula draws on a very strong tradition within Argentine literature of such experimentation with incompatible, dispersed, or overlapping temporalities, stretching from Borges and Cortázar to Piglia, cowriter of the script for La sonámbula.

The film's heterogeneous treatment of temporality is also evident in its 
use of technology. In most films, special effects are designed to blend with the content without drawing attention to themselves; in science fiction, however, Albert La Valley observes that they are ostentatiously paraded, to the extent that "the history of science fiction and fantasy movies is as much a statement about the development of movie technology as it is about the themes the movies ostensibly treat." 73 Such films become, in La Valley's analysis, "vehicles for declaring the institution's current state of the art," which is then superseded by more advanced techniques in subsequent films, demanding ever-increasing budgets to overcome the technical status quo. ${ }^{74}$ Science fiction films therefore inscribe themselves in a linear history of everadvancing technological progress. Like La antena, La sonámbula consciously breaks this logic. As a film about the future that combines up-to-date digital postproduction effects with conspicuously obsolete technology, such as the use of $\mathrm{I} 6 \mathrm{~mm}$ black-and-white film stock, it aims to produce-in the words of the film's director of photography_a "hibridización tecnológica" (technological hybridization). ${ }^{75}$

This strategy detracts significantly from realism in the film. Its vision of a futuristic Buenos Aires is deliberately unconvincing, its cityscapes clearly two-dimensional. ${ }^{76}$ The patent fragility of this vision-indeed, as the film reaches its climax characters often simply dematerialize-lends support to our suspicion that we should read the whole narrative as a (possible) dream. Beyond this, however, it also appears to pass comment on modernity's illusions of technological progress, as we see the city's streets strewn with the ruins of the past. It becomes evident that temporal disjuncture and mixture in the film are not solely the properties of interior, psychological time, but of historical time itself. As if the cinematic illusion of a hypermodern Buenos Aires were just too fanciful to sustain, it is punctured by the intrusion of profilmic evidence of neglect and decay, threatening the fabric of modernity at every turn. Many of the film's most phantasmagoric landscapes are shot in real locations in the city and province of Buenos Aires. As Kluge searches the dockyard for the ship he has seen in Eva's recorded dreams, he passes the corroding frames of boats that for years remained strewn along the old docks in La Boca in the real city of Buenos Aires, simply left to rust when the city's business moved to the new dockyards to the north. The devastated town Kluge and Eva pass through in their flight from the city-an oneiric vision of tree skeletons and ruined houses emerging from the floods - might evoke a postapocalyptic fantasy but was in fact shot on a real location in Epecuén, abandoned after flooding, and the sequence needed no postproduction work. ${ }^{77}$ One cannot think of a better illustration of Jameson's assertion, in 
the context of the "failure" of the utopian vision in science fiction, that "historical truth is always stranger and more unpredictable, more unimaginable, than any fiction," and that "this ultimate inability of the writer to create a genuinely alternate universe only returns us the more surely to this one."

On the other hand, the simultaneous evocation in La sonámbula of multiple, overlapping times conflicts strongly with the discourse of linear development that underpins Jameson's historicizing approach. His account of postmodernity is the story of capitalism's inexorable sweeping across the globe, erasing before it all past social orders to synchronize the world in the homogenized, standard time of modernity. ${ }^{79}$ While the global triumph of capitalism is of course a cause for lament in Jameson's work, he does not challenge the discourses of linear progress and inevitability that sustain its power. In La sonámbula's vision of Buenos Aires, the obsolete and abandoned are not superseded but form part of the landscape of the present; temporality is constructed not according to linear models of ever-advancing progress and cumulative technological development, but by ruptures, folds, bewildering acceleration, and wells of stagnation. We enter a kind of time that is less chronological and more topological, in which phenomena from distant historical moments find themselves in sudden proximity, and in which—as Serres puts it—- "Time doesn't flow; it percolates. This means precisely that it passes and doesn't pass." ${ }^{\circ 0}$

The technological mixture evident in the film's treatment of the modern cityscape, as well as its "hybridizing" use of old and new special effects, gives prominence to the techniques used in cinema to manipulate time. Montage, citation, and digital keying are among the principal ways in which the temporal fixing of images is altered in La sonámbula. Cinema's capacity to convey a virtuosic range of durations and speeds is evident from the opening sequence of the film, as the adagio clarinet melody, saturated colors, and slow camera movements evoking the tranquility of the country house suddenly give way to the frenetic rhythms and synthesized wails and shudderings of a video montage, accompanying an accelerating ride through a subway tunnel with bleached and distorted shots of different landscapes flashing before us. We fetch up, breathless, in front of a soundless, still image of Eva, draped in the most classical of fashions at the base of a huge statue. The use of contrasting speeds and the citation of wildly diverse aesthetic styles in music, graphics, sculpture, and film prepares us for La sonámbula's dense overlaying of different temporalities; it also demonstrates cinema's ability to create a single flow of time from multiple temporal objects, unfixing them from their origi- 
nal moment of inscription and meshing them together through montage, in an unceasing play of decontextualization and recontextualization.

For Bernard Stiegler, "This is the very principle of cinema: to connect disparate elements together into a single temporal flux." ${ }^{81}$ La sonámbula continually draws attention to this practice, as the disjointed fragments of Eva's predictive visions we see in the laboratory recordings are later woven, one by one, into the fabric of the main story. A similar effect is created by digital keying, which since the I990s has largely replaced the optical bluescreen techniques developed in the I930s to separate filmed elements from their background. When we first see the hotel, standing alone with its art deco arches in the featureless black-and-white plains that circle the city, it is a phantasmagoric, retrofuturistic image; when it is "replaced" alongside other buildings in the provincial town Eva reaches at the end of the film, filmed in naturalistic color, it becomes an entirely mundane and unremarkable building that blends perfectly with the faintly dilapidated environment of any current-day provincial town. Such techniques — of prolepsis and repetition, displacement and reemplacement-ensure that we do not experience the work of montage or mise-en-scène as seamless or natural, but glimpse the multiplicity of elements that a film draws together to form a single temporal object.

Viewing Eva's visions on a screen, Kluge is asked whether he is watching a film. He nods, admitting, "Algo asî" (Something like that). The "film" he watches is an externalization of Eva's visions, the technological means by which he can access the private consciousness of another, and which interpellates him into that vision, foretelling the conjoining of their experiences. When Kluge sees himself in Eva's visions, he understands that their destinies have unavoidably converged. These are not flashbacks that would suggest the irruption of the past into the present, but visions that become points of intersection between one world and another, one temporality and another. It is not simply that Eva's dreams predict what is to come, but that watching them on-screen affects the characters' perceptions and actions in such a way that they collaborate in making this future happen. Dr. Gazzar contracts Kluge to find Eva because it is "inevitable" that the job should be carried out by him, as it is he who features in Eva's dreams; watching recordings of Eva's visions gives Kluge the necessary clues to find her and to aid the intrusion of another (future or parallel) world into this one, an incursion that irrevocably alters its natural course.

The reflexive attention paid in La sonámbula to the act of viewing provides, I would suggest, a picture of the way in which cinema interpellates 
us into the experience of others, dissolving distinctions between private and public temporalities. If, as Heise suggests, "high modernism emphasizes the difference between private and public temporality," both have become "precarious categories" in postmodernism. ${ }^{82}$ La sonámbula identifies cinema as a key apparatus in creating a convergence between the two. Eva's cinematic visions, watched by Kluge and Gazzar on screens in darkened rooms, show them moments that will come to pass in their future. But in an important sense these visions have already become part of their experience, through cinema's ability to converge filmed time with the real time of spectatorship. As Stiegler suggests, "Cinema weaves itself into our time" by bringing its own temporal flux to coincide with the spectator's stream of consciousness. ${ }^{83}$ If the film—like Barthes's photograph-replays a recording made in the past, it constructs experience in the present: "The coincidence between the film's flow and that of the film spectator's consciousness, linked by phonographic flux, initiates the mechanics of a complete adoption of the film's time with that of the spectator's consciousness - which, since it is itself a flux, is captured and 'channeled' by the flow of images." ${ }^{84}$ It is "the fact that consciousness functions just like cinema, which has enabled cinema (and television) to take it over," Stiegler argues; ${ }^{85}$ in other words, both consciousness and cinema are temporal fluxes structured through montage, combining perceptions, recollections, and prosthetic memory in such a way that originary perception cannot be separated from the work of imagination or the mediation of technology. ${ }^{86}$

Helga Nowotny observes that, in modernity, "the private time of every man and woman has found its place, its time, in world time." With the rapid development of communication technologies, however, "This private time has become one which is always connectable, available, and public." ${ }^{87} \mathrm{La}$ sonámbula narrates this process, with all its ambivalence. It demonstrates the conversion of these technologies into one of the most sinister weapons in the state's armory of citizen control techniques, as it invades the private sphere of individual memory and identity. On the other hand, the externalization of memories and dreams by means of screen technologies in La sonámbula allows an encounter to take place with an alternative world. Alison Landsberg suggests that we read films on prosthetic memory "as an allegory for the power of the mass media to create experiences and to implant memories, the experience of which we have never lived." 88 This process of implantation or transmission erodes the boundaries of the subjective self in ways that connect us with other experiences, demonstrating the extent to which, as 
Stiegler suggests, "technics opens the possibilities of transmitting individual experience beyond the individual's life." ${ }^{9}$

\section{Conclusion: (Post)Modernity and Cinematic Time}

Although many theorists have rightly pointed to the rise of cinema in the early twentieth century as paradigmatic of modernity's relationship with time as mechanical, homogenized, and standardized, Lim reminds us that "the way in which cinema is a clock for seeing, an apparatus that links vision to rationalized time, is only one aspect of the cinema's relationship to temporality." ${ }^{\prime 00}$ Mary Ann Doane's study of early cinema makes a persuasive argument for the crucial role film played in the modern structuring of time, in bringing together two apparently opposed conceptions of temporality. As time becomes "increasingly reified, standardized, stabilized, and rationalized" in the late nineteenth and early twentieth centuries, ${ }^{91}$ we also witness the emergence of "epistemologies that valorize the contingent, the ephemeral, chance-that which is beyond or resistant to meaning." ${ }^{2}$ In tandem with Bergson, Doane notes that the mechanization and rationalization of time governs cinema's division of movement into static frames that are then combined to form the illusion of continuity. ${ }^{93}$ However, what was registered in film, and particularly the early actuality genre, was "life itself in all its multiplicity, diversity, and contingency." ${ }^{44}$

A century on from the early filmic experiments analyzed by Doane, our understanding of temporality is perhaps less consistently structured around modernist dichotomies between the rationalized and the contingent, and the public and the private. Rather than celebrating cinema's ability to capture the present moment, we are more likely now to appreciate that there is little about the "actuality" that was ever "actual" in the sense of being "of the moment," and that historical time, far from being the homogeneous, linear, standardized antithesis of subjective time, may be more accurately understood as polychronic, and is certainly modernity's own invention. Rather than pitting rational order and meaning against ephemerality and chance (the absence of meaning), the films I have discussed here perform moments of convergence between incompatible temporalities, including the chronological and the topological, the private and the public, or one parallel universe and another.

Recent work by Emily Keightley, Anna Reading, and others has helped 
to challenge our dominant conception of the time of modernity as one of speed/acceleration and simultaneity, as experiences imposed upon society by new media technologies. Such, for example, is the conception encouraged by Jameson, for whom postmodernity has paradoxically brought "an unparalleled rate of change on all the levels of social life and an unparalleled standardization of everything." ${ }^{95}$ This permits him to claim that we are witnessing "an effacement of the temporalities that seemed to govern an older period of modernity, of modernism and modernization alike." ${ }^{96}$ Keightley proposes instead that we should understand time as arising from "the nexus of interrelationships between media technologies, content and social practices of use." ${ }^{97}$ It is the social experience of time that has become sidelined in many accounts of modern temporality; far from being regimented by "clock time" or channeled into the simultaneity of media time, our experience of time, Keightley argues, is much more diverse, created by the intersection of multiple temporalities. As she claims, "Our temporal experience can swell to incorporate pasts, other presents and futures which we have not, or will not experience. The time of other people can interpenetrate our own, just as ours can interpenetrate theirs. Our experience of time is a social one." ${ }^{\prime 8}$ Reading similarly emphasizes that our experience of time arises from the "interferences, incitements and translations" between multiple temporalities, conceived as an assemblage. ${ }^{99}$

Significantly, neither La antena nor La sonámbula sustains a negative vision of video technologies as a method of social control. For all its concern with the dangerously mesmerizing power of television, La antena does not ultimately reprise the archetypal science fiction proscription of technology as a form of oppression and slavery, but also finds in it opportunities for the life-giving exercise of human imagination; in La sonámbula, video recordings of private memories and dreams may be appropriated for use by a repressive state, but they also mark the path to liberation. The use of (media) technology does not bind humans to an inexorable history of continual advancement, inscribing us within the linear time of modernity; it offers opportunities to challenge those discourses, to loop back to forgotten or unfinished moments in the past, to operate within different temporalities at the same time, or to acquire experiences beyond those of an individual life. As Keightley argues, "Mediated time is not simply a technical logic imposed on modern experience; this logic is creatively deployed and embedded in social life in a whole host of different ways. The timescapes of modernity emerge from the synthesis of these temporal elements." 100 Cinema, whose origins are so often claimed to be embedded in the rationalized, mechanized time of 
modernity, nevertheless responds to, and helps to construct, the experience of a temporality that is really an assemblage of many different temporalities.

"Movies about the future tend to be about the future of movies," Garrett Stewart observes, drawing attention to the reflexivity that is characteristic of so many science fiction films, their sets littered with video screens, scopic instruments, monitors and projectors of all kinds. ${ }^{101}$ Yet in the best films, Stewart maintains, this self-consciousness "may be an examined stance toward the external rather than a hunching inward," as they are primarily concerned, not with movies or art, but with "form itself, from telling to technology," revealing how scientific advances structure our lives. ${ }^{102}$ The reflexive interest in the technology of their own production that is strongly evident in La antena and La sonámbula becomes very much part of their extended meditation on temporality in the modern or contemporary world. Science fiction emerges as a privileged platform among film genres from which to mount a challenge to linear time. Lim suggests that "fantastic narratives strain against the logic of clock and calendar, unhinging the unicity of the present by insisting on the survival of the past or the jarring coexistence of other times." 103 Science fiction's commitment to a quasi realism in the construction of its worlds (unlike fantasy, which has no requirement for coherence and plausibility) means that it is able to subvert linearity, not simply by disrupting causality, introducing the irrational, or dissolving meaning, but crucially by opposing modern notions of time with other ways of understanding and experiencing temporality. If the science fiction film often stages a literal interpenetration of present and future, or of parallel universes, we may read this as an allegory for the work of cinema more generally, as a tool for the convergence of multiple temporalities.

The understanding of temporality that emerges in the accounts of Keightley, Reading, and others who insist on the diversity of our experiences of time in modernity is much richer, I would contend, than that which allows Jameson to lament the "waning" of historicity in postmodern science fiction, owing to its destruction of those linear notions of causality that he finds necessary in the construction of our present as a historical present. ${ }^{104}$ Jameson's ambivalence toward the critical potential of postmodern science fiction stems from his (Marxist) commitment to a concept of history as linear progression on the one hand, and on the other, his appreciation of the estranging effects of generic reflexivity in recent science fiction. Far from simply confronting us with the impossibility of utopian visions, however (the principal virtue that Jameson somewhat grudgingly concedes to the best postmodern science fiction), La antena and La sonámbula suggest to us 
the power of cinema both to register and to reshape the multiple, retrogressive, and crisscrossing temporalities that make up our present. Crucially, this makes possible a utopian thinking that does not posit the present as the inevitable consequence of past causes, and succeeds in deconstructing the linear notions of historical progress that have underpinned the discourses of modernity. In the case of La antena, it leads us to grasp the liberating fact that our present enthrallment to consumer capitalism is only one of many alternative paths that history might have taken, while La sonámbula turns the weapons of authoritarian control against the regime itself, finding in video technology's erasure of the distinctions between public and private temporalities a way of perceiving the existence of alternative worlds and orders beyond those of our own present experience. If neither film offers us a utopian vision of the future in the classic sense, both persuade us that cinema, and the cinematic apparatus, have a vital role to play in making such visions possible. If, for example (as Landsberg suggests), the images we see may affect us to such a degree that they become part of our own "personal archive of experience," they may provide "the grounds for political alliances" that transcend essentialist categories such as race, class and gender. ${ }^{105}$

David Harvey argues that Blade Runner does not have the power "to overturn established ways of seeing or transcend the conflictual conditions of the moment," as it is caught within contradictions proper to the cinematic form itself:

Cinema is, after all, the supreme maker and manipulator of images for commercial purposes, and the very act of using it well always entails reducing the complex stories of daily life to a sequence of images upon a depthless screen. ... Nevertheless, the malaise lies rather deeper than that. Postmodern art forms and cultural artefacts by their very nature must self-consciously embrace the problem of image creation, and necessarily turn inwards upon themselves as a result. It then becomes difficult to escape being what is being imaged within the art form itself. ${ }^{106}$

According to Harvey, then, it is the reflexivity of postmodern film that traps us within the dystopian visions it projects: an inward turn to explore imagemaking only implicates films within the same regimes of surveillance, manipulation, and repression that are so often the object of their critique. My discussion of Estrellas, Cóndor Crux, La antena, and La sonámbula has led to an opposing view. In these films, a reflexive approach to image creation and 
manipulation-particularly when coupled with a sense of cinema's role, as technics, in the shaping and convergence of temporalities—does not curb utopian visions but gives them new life.

Harvey, like many critics writing within a Marxist-materialist paradigm, is curiously reluctant to explore the materiality of the cinematic apparatus and the embodied nature of spectatorship, both of which suggest not (or not merely) the subjugation, via technology, of the individual within a capitalist system, but the potential, via technology, for new forms of liberation and collective experience. Reflexive strategies in all four films work to deconstruct the apparent linearity and universality of modernity, allowing a powerful critique to emerge of the historicist account of capitalist development. They also, however, interrogate the crucial role cinema continues to play in the construction of time: not just the time of mechanization, modernity, and history, or even that of chance, contingency, and the inner life, but also of social, multiple time, and time as an assemblage of heterogeneous temporalities, the starting point—for Benjamin—for a genuine critique of the discourse of progress. 


\section{Conclusion}

How can we theorize materiality without reducing it to discourse? This is the question addressed in Mark Hansen's Embodying Technesis: Technology beyond Writing (2000), in which he argues that the great majority of theorists of technology—among them, Heidegger, Freud, Lacan, Derrida, Foucault, and Deleuze and Guattari-have implemented a "reductive strategy that allows for a progressive assimilation of technology to thought." ${ }^{1}$ In other words, technology is invoked as a trope for, or an instance of, different forms of alterity, such as Heidegger's Being, Freud's unconscious, Derrida's différance, and Lacan's objet petit $a$, but it remains subordinate to an overriding theoretical project on subject constitution. ${ }^{2}$ Such theories, Hansen argues, remain faithful to "the logocentric foundation of philosophical humanismthe privilege of thought and/or the thinking agent" and thus fail to account for what he refers to as "the robust materiality of technology," which impacts our experience and influences our embodied lives in ways that cannot be captured in representation. ${ }^{3}$

At first sight, the strongly reflexive and metafictional approach of the texts discussed in this book, which often draw on science fiction tropes and technologies to reflect on the nature and status of the literary or cinematic text (or text-based performance practices), might seem to inscribe them within Hansen's "technesis," which involves "the translation of material technology in its concrete, worldly embodiment into a textualist analogue," and the use of technology simply to expand our understanding of the nature of textuality. ${ }^{4}$ However, I have argued that these texts cannot fully be co-opted to serve a poststructuralist or constructivist agenda, and do not attempt to reduce technology or materiality to that which may be represented in lan- 
guage or discourse. Instead, they stage the multiple exchanges that connect the text with the material world, embedding the text within an evolution of technology that is not subject to the evolution of culture but interacts with it in complex ways.

The theorists whose work I have found most illuminating in this study differ from those Hansen critiques, in their genuine efforts to posit a material realm of experience that exceeds human language, and indeed all human measures. Malabou's plasticity and Stiegler's understanding of the technological basis of temporal experience are both, as Ian James observes, "attempts to think a fundamental materiality of human life which is prior to or in excess of any economy of discourse, text, writing or of the symbolic." 5 The new materialist perspectives developed by De Landa and Braidotti locate the human within a matter with agentic capacities, which follows its own, inhuman, course of evolution. In Karen Barad's simple summary, "Matter is not a support, location, referent, or source of sustainability for discourse. Matter is not immutable or passive."

These newer forms of materialist thinking owe a considerable debt to Benjamin, the one theorist singled out by Hansen for his commitment to the irreducibility of embodied experience. ${ }^{7}$ Matter is often ascribed with agency in Benjamin's writing on modernity and the city: objects "have the ability to return the gaze," while "technology has subjected the human sensorium to a complex kind of training," imposing its own rhythms on the city-dweller. ${ }^{8}$ This dynamic is also intrinsic to the (re)materializing operations of graphic fiction, as we saw in chapter 2. Benjamin situates language within a broader realm of natural correspondences, positing a mimetic faculty that antedates the acquisition of language. ${ }^{9}$ As Hansen argues,

Benjamin historicizes the linguistic (textualist) model of the cosmos as specific to a particular (if particularly long and important) phase in human existence. Viewed in the broader context thus secured, language appears as one vehicle among others for our contact with the cosmos and one whose sway is by no means necessarily infinite. The structural open-endedness of his mimetic history leaves room for the introduction of a distinct postlinguistic form of mimesis that would restore a crucial dimension of sensuosity — a practical, embodied basis- to our contact with the material world. ${ }^{10}$

This interest in historicizing language and textuality as simply one form among many possible ways in which we come into contact with the sensory 
and material world is clearly shared by many of the writers explored in this book. It is particularly evident in Aira's El juego de los mundos, which takes as its central theme the shifts in human subjectivity and our relationship with the world that result from a change from a text-based culture to one organized around images and virtuality; in Spregelburd's dramas, which often explore mathematical paradigms as alternative, extralinguistic ways of understanding order in the world; in the continuity established between literature and other technological regimes of representation in La invención de Morel; and in Mairal's exploration of preliterate forms of cultural transmission in El año del desierto.

Technology in these texts does not sever our contact with the material world but brings it even more clearly into focus, a dynamic that is particularly evident in Oesterheld's (Marxist) understanding of the relationship between technology, nature, and human labor, or the various prosthetic devices of Cohen's fiction. It is for this reason, perhaps, that the cyborg or robot does not usually appear in these texts as a "menacing or threatening figure," as it so often does (as J. Andrew Brown observes) in U.S. science fiction films from the 1950s and 1960s; ${ }^{11}$ neither do forms of technological simulation or artificial life necessarily sound the death knell for humanity. Many of the more recent writers and directors discussed here-Blaustein, Cohen, Aira, Spregelburd, and Spiner-embrace a posthuman condition in which technology has become, and perhaps has always been, an integral part of the circuits that traverse the boundaries of the human body, offering vast opportunities for cultural expression and intersubjective experience at the same time that it facilitates political pacification and homogenization. As Roger Bartra notes, science fiction cyborgs provide a model for an increasingly well-supported theory of consciousness that links internal brain processes with external circuits located in the environment. ${ }^{12}$ These texts do not call for the overthrow of robots but for a greater understanding of the processes that bind humans to the material (technological or natural) world, on the basis of which—as Stiegler and Malabou contend—we may begin to transform those relationships.

I suggest that we may read the prevalence of (post-)Darwinian perspectives in Argentine science fiction within the context of a sustained critique of capitalism and liberal ideas of progress that dates back to the nineteenth century and persists, in shifting forms, to the present day. As Alex Levine and Adriana Novoa affirm, Darwin's theory of evolution met with some unease in Argentina. If official state discourses accorded with a Spencerian vision of the inevitability of progress wherever civilization was embraced, Darwinian 
natural selection offered in its place "an understanding of civilization as the product of a process of selection whose outcome was far from universally assured." ${ }^{13}$ Holmberg's Viaje maravilloso del Señor Nic-Nac depicts a Buenos Aires that is more interested in gold than the spiritual and intellectual riches of the enlightened Sophopolis, but more given to destructive in-fighting than to developing the country's natural resources. Writing a little later, around the time of the economic crisis of 1890 , Eduardo de Ezcurra presents in his En el siglo XXX (I89I) a vision of a future Buenos Aires in which technological advance has not been accompanied by social progress. The citizens of "la colosal ciudad de los pasmosos progresos y de las supinas banalidades" (the colossal city of astonishing progress and crass banalities) ${ }^{14}$ are almost entirely given over to mercantilism and enslaved to hyperconsumerism, and as a result, society is conspicuously lacking in social cohesion, intellectual culture, and moral values.

Ezcurra's understanding that evolution may run "backward" as well as "forward," toward degeneration and decadence as well as greater civilization, is thoroughly Darwinian. For Argentine intellectuals, Levine and Novoa observe, "Darwin introduced uncertainty in the direction of evolutionary change" and the fear that "not every change is a change for the better." ${ }^{15}$ Social readings of Darwin articulated a concern that scientific progress might not lead to a more rational society but to a more selfish one, in which the traditional values of virtue and integrity were cast off. Buenos Aires also careers precipitately "backward" toward barbarism in Plop, Cruz diablo, and El año del desierto in ways that are, as shown in chapter 3, thoroughly imbricated with a critique of the ecological consequences of advanced capitalism $(P l o p)$, its deepening of social and economic inequality (Cruz diablo), and the cutthroat cannibalism that lies thinly disguised beneath a veneer of civilization (El año del desierto). Other texts, such as Estrellas and Cóndor Crux, la leyenda, challenge the linearity that underpins the historicist understanding of modernity and capitalist development.

For Stiegler, Darwinist adaptation by natural selection is an insufficient model to understand human evolution, which has relied in greater part on our ability to transmit experience from one generation to the next, and to use technology to overcome maladaptation. Gerald Moore argues that "our failure to see this distinction has been exacerbated by the adaptationist ideology of contemporary capitalism, which suppresses adoption-the possibility of inventing an alternative future-and naturalizes adaptation as the defining characteristic of human society." 16 A number of the texts explored here emphasize instead the importance of adoption over adaptation, representing 
technics (recorded memories in La sonámbula; a singing prosthesis in Cruz diablo; the vividness of the cinema screen in Quiroga's stories; the worlds game in El juego de los mundos; the Panconciencia network and other forms of prostheses in Cohen's novels) as means of enhancing human knowledge and experience. This emphasis on adoption opens up a possible critique of the survival-of-the-fittest discourse that underpins capitalism and, importantly, provides a potential basis for utopian thought, allowing us to imagine alternatives.

In response to her own central question- "What should we do so that consciousness of the brain does not purely and simply coincide with the spirit of capitalism?"-Malabou urges us to grasp the nature of the brain as plastic: not flexible, simply aligning itself with the "flexible" working practices of contemporary capitalism and its demand for adaptation, but offering the resilience and resistance of plasticity, having "the resource of giving form, the power to create, to invent or even to erase an impression, the power to style." ${ }^{17}$ For Malabou, it is understanding the brain's capacity to give form as well as to receive it that will enable us to resist the logic of Darwinist selection that permeates and naturalizes a certain social order. ${ }^{18}$ Drawing on a heritage of materialist thought, the more recent texts studied here participate in what Hansen describes as "the affirmative task of exploring new technologically mediated, posthuman forms of human agency," or in other words, the task of grappling with the consequences of the displacement of the human in the face of "technology's inhuman evolution." 19

While an important strand in science fiction has pitted the technological against the human, the texts I have discussed are more likely to propose that, as Robert Sinnerbrink suggests in his discussion of Stiegler's technics, "fully-formed autonomous subjectivity does not just confront technology as a readymade set of instruments," but that technology itself has formed what we understand to be distinctively human, and made possible "our historical experience of time, memory, and consciousness." ${ }^{20}$ It is the reflexive focus of these texts that therefore promotes a materialist understanding of the relationship between text, culture, technology, and nature, and that allows us to glimpse ways in which "technicity opens up, rather than simply threatens, the adventure of human individuation and collective co-existence." ${ }^{21}$ 


\section{Notes}

\section{Introduction}

I. Gandolfo, El libro de los géneros, 37. All translations not otherwise attributed are my own.

2. Drucaroff, "Narraciones de la intemperie."

3. Capanna, Ciencia ficción, 279-80.

4. Ibid., 42.

5. Drucaroff, "Narraciones de la intemperie."

6. Gorriti, "Quien escucha su mal oye," 7I, 72.

7. Waugh, Metafiction, 2, 3.

8. Reati, Postales del porvenir, I6.

9. Ibid., I9.

Io. Broderick, Reading by Starlight, xiii.

II. Capanna, "Ciencia ficción criolla," 49.

I2. Lemmens, "'This System Does Not Produce Pleasure Anymore," 35.

13. Hayles, How We Became Posthuman, I25.

I4. McLuhan, The Medium Is the Massage, 26, 34-37.

I5. Dubatti, Filosofía del teatro I, 26.

I6. Broderick, Reading by Starlight, I5.

I7. Braidotti, Metamorphoses, I83.

I8. See Stephen Jay Gould's discussion of Engels's I876 essay "The Part Played by Labor in the Transition from Ape to Man." An Urchin in the Storm, III-I2.

19. Bellamy Foster, Marx's Ecology, 201.

20. Marx, Capital, r:493 n. 4.

2I. Marx, Early Writings, I27.

22. Bellamy Foster, Marx's Ecology, 158.

23. Marx, Grundrisse, 494.

24. Bellamy Foster, Marx's Ecology, I63. 
25. Boscagli, Stuff Theory, 5 .

26. Ibid., 40.

27. See Germain, "The Human Condition in the Age of Technology," I6I, for further discussion of this point.

28. Hansen, Embodying Technesis, 8, 4.

\section{Chapter 1}

I. Rodríguez Pérsico, Relatos de época, 333-34.

2. Holmberg, Viaje maravilloso, 76.

3. Ibid., 38 .

4. Of Flammarion's texts, three of those translated into Spanish were of particular influence on Holmberg: La pluralidad de los mundos habitados (Madrid: Gaspar y Roig, I873); Los mundos imaginarios y los mundos reales (Madrid: Gaspar y Roig, I873); Lumen (Madrid: Gaspar y Roig, 1874).

5. Gasparini, "La fantasía científica," I27.

6. Laera, "Introducción," 9.

7. Haywood Ferreira, The Emergence of Latin American Science Fiction, 38.

8. Pérez Rasetti, "La locura lúcida," 213.

9. Crash Solomonoff, "Eduardo Holmberg," I3.

IO. Holmberg, Viaje maravilloso, 133 .

II. Pagés Larraya, "Estudio preliminar," 93.

I2. Frederick, "A State of Conviction, a State of Feeling," 59.

13. Gasparini, Espectros de la ciencia, 22.

I4. Ibid., 22-23.

I5. Crash Solomonoff, "Eduardo Holmberg," 23.

16. Haywood Ferreira, The Emergence of Latin American Science Fiction, 36.

I7. Ibid., 42; the citation is from Viaje maravilloso, 179.

18. Holmberg, Viaje maravilloso, IIo.

I9. Ibid., I44.

20. Ibid., I47.

2I. Ibid.

22. Ibid., I53-54.

23. Alberdi, "Gobernar es poblar," I9.

24. Bruno, Pioneros culturales de la Argentina, I55.

25. Ibid.

26. Holmberg, "El Museo de Buenos Aires: Su pasado—su presente—su porvenir."

27. Cazaux, Historia de la divulgación cientifica en la Argentina, 83; see also Cortiñas, "Un recorrido por la historia del libro de divulgación científica"; Laera, "Novelas argentinas," 97.

28. Laera, "Novelas argentinas," I05.

29. This is a reference to the brief civil war in I874, which followed the contested result of a presidential election. 
30. Holmberg, Viaje maravilloso, 3I.

3I. Ibid., 32.

32. Ibid., 32, 177 .

33. Ibid., I79.

34. Ibid.

35. Ibid., I54.

36. Ibid., 40.

37. Viaje maravilloso and Dos partidos en lucha predate Wells's first novel by twenty years, but the most well known of Wells's narratives fall in the period between Holmberg's early fiction and his last novel, Olimpio Pitango de Monalia (I915).

38. Evans, "Nineteenth-Century SF," I7, 21.

39. Holmberg, Viaje maravilloso, 69.

40. Ibid., 38.

4I. Gasparini, Espectros de la ciencia, 47.

42. Cazaux, Historia de la divulgación cientifica en la Argentina, 95-96.

43. Ibid., 96.

44. Ibid., 94-95.

45. Holmberg, Dos partidos en lucha, 89.

46. Le Bon, Psicología de las masas, 57.

47. Holmberg, Olimpio Pitango de Monalia, I8I.

48. Ibid., I90; my emphasis.

49. Rodríguez Pérsico, “'Las reliquias del banquete' darwinista," 386.

50. Rodríguez, Civilizing Argentina, 5.

5I. Terán, Vida intelectual en el Buenos Aires de fin-de-siglo, 20.

52. Ibid.

53. This version, published in Gente, was illustrated by Alberto Brecchia in a markedly more avant-garde style. The journal called off the serialization, resulting in a rushed ending and considerable loss of narrative coherence.

54. For more information on the relationship between Oesterheld, Peronism, and Montonero discourse, see Von Sprecher, "Discurso montonero en las historietas de Héctor Germán Oesterheld."

55. De Santis, La historieta en la edad de la razón, 76-77.

56. Miguel Briante, for example, argues that the first part of El Eternauta cannot be read without the second part, "Y nada de eso puede ser leído desde otro lugar que no sea el de la profunda, abismal realidad contemporánea: las cuatro hijas de Oesterheld caídas en el terremoto minucioso de la represión militar, el mismo Oesterheld desaparecido en el otoño de I977" (And none of it can be read from any perspective other than that of the deep abyss of contemporary reality: Oesterheld's four daughters fallen in the methodical earthquake of military repression, Oesterheld himself disappeared in the autumn of 1977). "La galera del tiempo," 20. In the words of Víctor Bailo, one of the directors of H.G.O. (Argentina, 1988), a documentary on the writer's life, "A Oesterheld su lucidez como artista/intelectual le había permitido ver más allá de su época y [pudo] anticipar los efectos de una determinada estructura de poder" (Oesterheld's lucidity as an artist/intellectual had allowed him to see 
beyond his contemporary moment and anticipate the effects of a particular power structure). Silva, "H. G. O.”

57. Fraser and Méndez, "Espacio, tiempo, ciudad," 58; Rubione, "H. G. Oesterheld," 229-30.

58. Briante, "La galera del tiempo," 2 I.

59. Sarlo, Una modernidad periférica, 55-57.

6o. Oesterheld and Solano López, El Eternauta, 77.

6I. Gociol and Rosemberg, La historieta argentina, 515.

62. Oesterheld and Solano López, El Eternauta, 89.

63. Ibid., 97.

64. Ibid., 2.

65. See Sasturain, El domicilio de la aventura, I88; García, "El eternauta, la zona de exclusión y la democracia," 34 .

66. Terán, "Ideas e intelectuales en la Argentina," 65.

67. Sigal, Intelectuales y poder en la década del sesenta, I68. Sigal notes wryly that the "tramo final" (final phase) of the project "podía ser dibujado, al fin de cuentas, según la voluntad ideológica de cada uno" (could be sketched out differently, in the end, according to one's own particular ideological orientation), which perhaps explains both its appeal and its rapid disintegration.

68. Oesterheld and Solano López, El Eternauta, 93.

69. Terán, "Ideas e intelectuales en la Argentina," 67.

70. Foucault, "Truth and Power," 67.

7I. Deleuze and Foucault, "Intellectuals and Power," 206-7.

72. Terán, De utopias, catástrofes y esperanzas, 90-9I.

73. Ibid., 82 .

74. Terán, "Ideas e intelectuales en la Argentina," 80.

75. Gilman, Entre la pluma y el fusil, I63.

76. Conti, "Compartir las luchas del pueblo," 536-37. Originally published in Crisis I6 (August 1974).

77. Oesterheld and Solano López, El Eternauta II, 92.

78. Ibid., 35 .

79. Ibid., 208.

80. Von Sprecher, "Discurso montonero en las historietas de Héctor Germán Oesterheld," 6o-6r.

8I. Oesterheld and Solano López, El Eternauta II, 203.

82. Ibid., 99, 143.

83. This reading is also suggested by Martín García. However, García’s account of the futility of the struggle "con destino al holocausto final" (heading toward the final holocaust) is telling of the extent to which his analysis of the first series is still oriented toward the imaginary of dictatorship rather than civil war and influenced by a knowledge of the political context of the second series. See "El eternauta, la zona de exclusión y la democracia," 35-36.

84. Oesterheld and Solano López, El Eternauta, I9.

85. Oesterheld, "El pueblo echa al invasor inglés." Originally published in El descamisado II (3I July I973). 
86. Sarlo, Tiempo pasado, 90-91.

87. Bourdieu, "The Intellectual Field," I45.

88. Terán, "Ideas e intelectuales en la Argentina," 80.

89. Bourdieu, "The Uses of the People," I50-5I.

90. Ibid., I50.

9I. Sigal, Intelectuales y poder en la década del sesenta, 25I-52.

92. Foucault, "The Concern for Truth," 265.

93. See Fernández and Gago, "Al que le quepa la escafandra que se la ponga" for an extended discussion of the appropriations of the Eternauta image and the politics of "Nestornauta" in particular.

94. Kuntscher and Miret, El maravilloso viaje del señor Nic-Nac, 35.

95. Quereilhac, La imaginación cientifica, 207.

96. Holmberg, "Horacio Kalibang o los autómatas," 32.

97. Holmberg, Viaje maravilloso, I09.

98. Holmberg, "El ruiseñor y el artista," I27.

99. Marx, Capital, I:493 n. 4.

\section{Chapter 2}

I. Ministerio was serialized in Fierro: Historietas para sobrevivientes (Comics for Survivors), the nation's premier magazine of the transition period, and later published as a compilation in the Fierro "Historieta Argentina" collection (2009).

2. See Gociol and Rosemberg, La historieta argentina, 50.

3. Christiansen, "Comics and Film," II8.

4. Judith Gociol and Diego Rosemberg note that the first weekly publication dedicated entirely to comics in Argentina, El Tony, which appeared in 1928, largely featured Raúl Roux's adaptations of classic stories such as "Hansel and Gretel" and "Robinson Crusoe." La historieta argentina, 23. Much later, Fierro contributed to a well-established tradition by publishing an important series of adaptations of Argentine literary classics, La Argentina en pedazos (1984), with introductory texts by Ricardo Piglia.

5. Pfister, "How Postmodern Is Intertextuality?," 2I4-I5.

6. Bertens, The Idea of the Postmodern, II.

7. Ahrens and Meteling, "Introduction," 5.

8. Enns, "The City as Archive in Jason Lutes's Berlin," 45.

9. Ahrens and Meteling, "Introduction," 7.

Io. Ibid.

II. See McCloud, Understanding Comics; Groensteen, Système de la bande dessinée, published in English as The System of Comics.

I2. Suhr, "Seeing the City through a Frame," 24I.

13. Ahrens and Meteling, "Introduction," 5.

I4. Gilloch, Myth and Metropolis, I83.

I5. Benjamin, Selected Writings, vol. 3, I935-1938, II7.

I6. Benjamin, Walter Benjamin: Selected Writing, vol. 2, part 2, I93I-I934, 775.

17. See Benjamin, One-Way Street, 66. 
18. Gardner, "Archives, Collectors, and the New Media Work of Comics," 789.

19. Incomplete versions of Ciudad were published in Tiras de cuero (1983) and Hora Cero (1990), but the series was only published in its entirety in book form by Ediciones de la Urraca in 1992.

20. Cain was serialized in Fierro from 1988. The episodes were collated in book form and published by Ediciones de la Urraca in 1993, with a second edition released by Ediciones Norma in 2005 .

2I. Barreiro and Giménez, Ciudad, II, I4. The book-length compilation published by Ediciones de la Urraca does not have sequential page numbers. The numbers given here have been calculated starting from the opening page of the first episode.

22. Simmel, "The Metropolis and Mental Life," 324.

23. Barreiro and Giménez, Ciudad, I59.

24. Gilloch, Myth and Metropolis, 9.

25. Benjamin, The Arcades Project, $\mathrm{I} 3$.

26. Enns, "The City as Archive in Jason Lutes's Berlin," 49.

27. García Canclini, Imaginarios urbanos, Io9.

28. Barreiro and Giménez, Ciudad, I52.

29. Similar techniques were to be more radically employed in Chris Ware's graphic novel Building Stories (2012).

30. García Canclini, Imaginarios urbanos, 82.

3I. Wolfe, The Known and the Unknown, 87.

32. García Canclini, Imaginarios urbanos, 32.

33. Ibid., 87.

34. Barreiro and Risso, Cain, 55.

35. Benjamin, One-Way Street, 66.

36. Ibid.

37. Balzer, "Hully Gee, I'm a Hieroglyph," 3I-32.

38. Barreiro and Risso, Caín, II.

39. In fact, Cain turned out to be eerily prophetic of an even more cozy relationship between big business and the state. Carlos Menem, elected as president the year after the publication of Cain, ushered Argentina into full-blown neoliberalism during the I990s. His first two ministers of the economy were chief executives from Bunge and Born.

40. As an exception to this, an acknowledgment placed at the end of the script identifies the character Narigazo as a homage to Oesterheld's Bull Rocket.

4I. Gardner, "Archives, Collectors, and the New Media Work of Comics," 788, 799.

42. Ibid., 8oI.

43. Ibid., 803 .

44. Enns, "The City as Archive in Jason Lutes's Berlin," 47.

45. Slot-Barr was Barreiro's first solo work as a scriptwriter. Work with Solano López began in 1976 and was completed in exile in Spain. The series was published in three albums by Madrid's Ediciones B. O. in 1979, and eventually serialized in 
Argentina in 1987, in Skorpio, at that point running under the title Super Skorpio. Colihue published the compilation in 2009, but as an incomplete series: the printing plates for the final twelve chapters had been lost in a fire in the illustrator's study, in circumstances that remain unexplained. See Steimberg, "El discurso más allá de las palabras," 4 .

46. Gardner, "Archives, Collectors, and the New Media Work of Comics," 800.

47. Enns, "The City as Archive in Jason Lutes's Berlin," 57.

48. Nora, "Between Memory and History," I4.

49. Huyssen, Present Pasts, 23.

50. Barreiro and Solano López, Slot-Barr, io6.

5I. Ibid., I06. 94.

52. Ibid., I22.

53. Frahm, "Weird Signs," I79-80.

54. A newly launched version of the series has so far published around fifty titles since 2008.

55. Parque Chas was serialized in Fierro in 1987 and published in book form by Puro Comic in 2008.

56. Berone, La fundación del discurso sobre la historieta en Argentina, 32.

57. Gilloch, Myth and Metropolis, I82.

58. Best and Kellner, The Postmodern Turn, I32.

\section{Chapter 3}

I. Vanasco, "Post-Bombum," I42.

2. Fukuyama, The End of History and the Last Man, 87-88.

3. Ibid., 89.

4. Pinedo, Plop, 45.

5. My reading departs here from Zac Zimmer's more hopeful assertion that, through Plop's careful guarding of the book, "something of the past remains in the present, even the postapocalyptic present" and that, although the book is finally buried in the mud, prefiguring its owner's fate a few pages later, "Plop's truth hibernates." "Barbarism in the Muck of the Present," I40, I44.

6. Pinedo, Plop, I37.

7. Sterelny, The Evolved Apprentice, 23.

8. Ibid., 65 .

9. Ibid., 66.

Io. Ibid., 65 .

II. Stiegler, Technics and Time I, ix.

I2. Stiegler, Technics and Time 3, 206.

13. Stiegler, Technics and Time 2, I2.

I4. Pinedo, Plop, ıог.

15. Zimmer, "Barbarism in the Muck of the Present," I4I.

I6. Parrinder, "Introduction: Learning from Other Worlds," 6.

17. The precise nature of "la intemperie" is never described in the novel: we 
merely witness its devastating effects. My translation here aims to capture the connotations of being exposed and weather-beaten carried by the Spanish word. "Estar a la intemperie," for example, is to be at the mercy of the elements.

I8. Mairal, El año del desierto, I49.

19. María A. Semilla Durán, for example, identifies the novel's "escena matriz" (core event) as the "quiebra generalizada" (general collapse) provoked by the Crisis. "El Apocalipsis como deconstrucción del imaginario histórico," 328.

20. Juan de Garay was responsible for the city's second (and definitive) founding, in 1580 .

2I. Schmídel, Viaje al rio de la Plata, I534-I554, chapter 9.

22. Semilla Durán, "El Apocalipsis como deconstrucción del imaginario histórico," 340.

23. Zimmer, "A Year in Rewind, and Five Centuries of Continuity," 38r.

24. Mairal, El año del desierto, 256.

25. In a playful twist that reinforces this reversal of fortune, and the chasm between the nation's aspirations and its downfall, Mairal makes María the granddaughter of Eveline Hill, Joyce's fictional character, who in this rewritten version does eventually travel to Buenos Aires.

26. Semilla Durán, "El Apocalipsis como deconstrucción del imaginario histórico," 327.

27. Mairal, El año del desierto, IoI.

28. Friera, "'Me gustó trabajar con la paranoia de la clase media' [interview with Pedro Mairal]"; Arlt is not quite as precise in locating the shooting, but he does place the victim on Avenida Roque Sáenz Peña, otherwise known as Diagonal Norte, having recently passed Maipú.

29. Semilla Durán, "El Apocalipsis como deconstrucción del imaginario histórico," 330.

30. Stiegler, Technics and Time 3, 206.

3I. Ibid.

32. Mairal, El año del desierto, 260.

33. Bartra, Anthropology of the Brain, 95.

34. Mairal, El año del desierto, 263.

35. See Stiegler, Technics and Time 2, 7; Technics and Time I, 32.

36. Freedman, Critical Theory and Science Fiction, 50.

37. James, The New French Philosophy, 66.

38. Blaustein, Cruz diablo, 63.

39. Stiegler, Technics and Time 1,32 .

40. Stiegler, Technics and Time 2, 2.

4I. Blaustein, Cruz diablo, I38.

42. Ibid.

43. Foucault, The History of Sexuality, I:I40.

44. Stiegler, "Within the Limits of Capitalism, Economizing Means Taking Care."

45. See, for example, Stiegler, Acting Out, 53-55; Technics and Time 3, I2I. 
46. Stiegler's concept of individuation draws on Gilbert Simondon's L'individuation psychique et collective (1989), which posits the individual subject as an effect of the individuation process, rather than a cause, and understands individuation as a process that creates both an individual and a collective subject. See Technics and Time 3, 93-I03.

47. Blaustein, Cruz diablo, 234.

48. Stiegler, Technics and Time I, 85 .

49. Ibid., 3.

50. Stiegler, Technics and Time 3, 75.

5I. King, Science Fiction and Digital Technologies in Argentine and Brazilian Culture, 98, 106.

52. Dabove, Nightmares of the Lettered City, I79-80.

53. Sarmiento, Facundo, 87.

54. Blaustein, Cruz diablo, 28.

55. Ibid., I4.

56. Ibid., 53 .

57. See, for example, ibid., I4, 53.

58. Ibid., I4.

59. Ibid., I95.

6o. Ibid., 53 .

6I. Sarmiento, Facundo, 94.

62. Ibid.

63. Blaustein, Cruz diablo, 63.

64. Ibid., I9.

65. Ibid., I42.

66. Reati, Postales del porvenir, 80.

67. Porteño describes the inhabitants of Buenos Aires.

68. Blaustein, Cruz diablo, 2I.

69. Ibid., 22.

70. Ibid., 3I.

7I. Ibid., 247.

72. Ibid., 29I.

73. Ibid., 290, 291.

74. Van Camp, "From Biopower to Psychopower."

75. Fukuyama, The End of History and the Last Man, xi.

76. Drucaroff, "Narraciones de la intemperie." Clarin is one of the most widely circulated national newspapers in Argentina.

\section{Chapter 4}

I. Bukatman, Terminal Identity, 28.

2. Ibid., 29.

3. Ibid., 29-30.

4. Bradbury, Fahrenheit 45I, I07-8. 
5. For a comprehensive account of the first cinematographic exhibitions and the early years of Argentine cinema, see Caneto et al., Historia de los primeros años del cine en la Argentina, I895-I9I0.

6. See Borge, Avances de Hollywood, Io; Rivera, "Prólogo," 8; Goldstein, "Artistas e intelectuales argentinos ante "La quimera del . . cine,"” 39I.

7. Borge, Avances de Hollywood, IO-II.

8. Arlt, Notas sobre el cinematógrafo, 8I-82.

9. Ibid., 20.

Io. Ibid., I09-Io.

II. Ibid., III.

I2. Quiroga, Cine y literatura, 266.

I3. Ibid., 267.

I4. See, for example, ibid., I69, 196.

I5. Ibid., 263, 328.

16. Morin, The Cinema, or The Imaginary Man, I6.

17. Quiroga, Cine y literatura, 286.

I8. Ibid., I29.

I9. Quiroga, "El espectro," 484.

20. Quiroga, "El vampiro," 39-40.

2I. The hypothesized existence of $\mathrm{N}$ rays was a hotly debated issue in science in the early I900s, finally discredited and now seen as an extraordinary episode of mass delusion among scientists of the day. See Gratzer, The Undergrowth of Science, chapter I.

22. Gratzer, The Undergrowth of Science.

23. Ibid., 27.

24. Quiroga, "El espectro," 48I.

25. Sarlo, La imaginación técnica, 29.

26. Ibid., 23, 42.

27. Rocca, "Horacio Quiroga ante la pantalla," 29, 35.

28. Quiroga, "El vampiro," 3 I.

29. Ibid., 34 .

30. Quiroga, "El puritano,” 82.

31. Sarlo, La imaginación técnica, 23.

32. Quiroga, "El espectro," 482.

33. Morin, The Cinema, or The Imaginary Man, 204.

34. See, for example, De Toro, "Breves reflexiones sobre el concepto de lo fantástico de Bioy Casares en La invención de Morel y Plan de evasión," I50-5I; Kantaris, "Cyborgs, Cities, and Celluloid," 6I.

35. Baudrillard, "Simulacra and Simulations," I82.

36. Bioy Casares, La invención de Morel, 91.

37. Ibid., I07.

38. Nitsch, "La isla de las reproducciones," I57.

39. Bioy Casares, La invención de Morel, IоI.

40. Ibid., I07. 
4I. Nitsch, "La isla de las reproducciones," I57-58.

42. Ibid., 158-59.

43. Ibid., 156.

44. Bioy Casares, La invención de Morel, IO2.

45. Ibid., 28.

46. Ibid., 70.

47. Morin, The Cinema, or The Imaginary Man, 70.

48. Bioy Casares, La invención de Morel, 85 .

49. Ibid., 8I.

50. Morin, The Cinema, or The Imaginary Man, 86.

5I. Ibid., 85 .

52. Ibid., 210, 209.

53. Ibid., I69.

54. Aira, El juego de los mundos, 25.

55 . Ibid., 63.

56. Ibid., 3I.

57. Ibid., 26.

58. Ibid., 74 .

59. Ibid., 73 .

6o. Ibid., 78 .

6r. Ibid., 57 .

62. Ibid., 52.

63. Ibid., 53 .

64. Ibid., I6-17.

65. Ibid., 63.

66. Clark, Natural-Born Cyborgs, 5 .

67. Ibid., 32.

68. Sterelny, The Evolved Apprentice, 5 (my emphasis).

69. Malabou, What Should We Do with Our Brain?, 4I-42.

70. Ibid., 33 .

7I. Aira, El juego de los mundos, 6I.

72. Ibid., 6I-62.

73. Another novel, Las curas milagrosas del Doctor Aira (1998), points selfreferentially to the existence of a totalizing project, uniting an infinity of individual installments into "una Enciclopedia general y total." Las curas milagrosas del Doctor Aira, 39.

74. Malabou, What Should We Do with Our Brain?, 5, I7-29.

75. Ibid., 79.

76. Aira, El juego de los mundos, 7I.

77. Ibid., 25 .

78. García, Degeneraciones textuales, 50.

79. Ibid., 5I.

80. Adorno, The Culture Industry, 92, 95.

8I. See, for example, Baudrillard, Simulacra and Simulation, 43-48. 
82. De los Ríos, Espectros de luz, I7.

83. Malabou, Plasticity at the Dusk of Writing, 57.

84. Derrida, Of Grammatology, 9.

85. Malabou, Plasticity at the Dusk of Writing, 59.

86. Ibid., 79.

87. Ibid., 60.

88. James, The New French Philosophy, 99.

\section{Chapter 5}

I. Malabou, Plasticity at the Dusk of Writing, 57-58.

2. Ibid., 6I.

3. James, The New French Philosophy, ro9.

4. Dolphijn and Van der Tuin, New Materialism, 2I.

5. Ibid., 93.

6. Coole and Frost, "Introducing the New Materialisms," 27.

7. The play premiered in 2003 in Catalan, at the Teatro Lliure in Barcelona; the first performance in Spanish took place in 20II, at the Teatro Cervantes, Buenos Aires.

8. Daulte, "Juego y compromiso."

9. Daulte, “4D Óptico,” I34.

Io. Heredia, "El teatro de Javier Daulte o la pregunta por lo humano," 42.

II. Daulte, “4D Óptico,” I23.

I2. Automáticos was first performed in Catalan in 2005 at the Teatro Alegría in Terrassa, Catalunya; the première of the Spanish version took place in 2007, at the Teatro Timbre 4 in Buenos Aires.

I3. Abraham, "La difícil tarea de no representar"; in its construction of a potential link between two stories separated in time and space, Abraham finds the fictional procedure of La modestia to be similar to that of another story by Cortázar, "Todos los fuegos el fuego." Abraham, "Un teatro al acecho de la complejidad de lo real."

I4. Daulte, "Juego y compromiso."

I5. Spregelburd, La paranoia, 36.

I6. Ibid., Ioo.

I7. Ibid., IOI.

I8. Dubatti, "Hacia una relectura post-postmoderna del teatro argentino," I76.

I9. Ibid., I72.

20. Ibid., I77.

2I. Dubatti, "Nota epilogal," 267.

22. Dubatti, "Hacia una relectura post-postmoderna del teatro argentino," I78.

23. Spregelburd, La paranoia, I22.

24. Coole and Frost, "Introducing the New Materialisms," I3-I4.

25. Hernández, "Entrevista: Rafael Spregelburd," 46.

26. Abraham, "La difícil tarea de no representar."

27. Spregelburd, La paranoia, 23. 
28. Ibid., I37.

29. Ibid., 95.

30. Ibid., 85 .

31. Borkenztain Szeiman, "Hermeneptalogía de Hieronymus Bosch," 207.

32. Spregelburd, "Respuestas a las preguntas de Jorge Dubatti para la edición de La paranoia," I68.

33. Ibid., 167.

34. Spregelburd, La paranoia, II8.

35. Hernández, "Entrevista," 49.

36. Dubatti, Filosofía del teatro I, 64.

37. Jürs-Munby, "Introduction," 4.

38. Heredia, "El teatro de Javier Daulte o la pregunta por lo humano," 37.

39. Deleuze, The Fold, 38. The book was originally published in French as Le pli:

Leibniz et le baroque, in 1988, and in Spanish translation as La pliegue, in 1989.

40. Gamerro, Ficciones barrocas, I8-I9.

4I. For a broader discussion of Cohen's engagement with scientific theories of entropy, complexity, and emergence, see Page, Creativity and Science in Contemporary Argentine Literature, I52-58, I84-22I.

42. De Landa, "Emergence, Causality and Realism," 392.

43. Rancière, The Flesh of Words, 148.

44. Cohen, "Variedades," I3.

45. Ibid., 52.

46. Hume, A Treatise of Human Nature, book I, part IV, section 6: "Of Personal Identity."

47. Cohen, "Variedades," I33, 52.

48. Ibid., I2.

49. Ibid., 76.

50. Rancière, The Flesh of Words, I2I.

5I. Braidotti, Metamorphoses, 75.

52. Cohen, "Variedades," 52.

53. The phrase is associated with Paul Ricoeur's work on Nietzsche, Marx and Freud, whom he dubbed the "three masters" of "the school of suspicion." Freud and Philosophy, 32.

54. Cohen, "Variedades," I3.

55. Ibid., 4I.

56. Colebrook, Gilles Deleuze, Ioo.

57. Ibid., 91.

58. Rancière's essay is, in part, a reading of Deleuze's "Bartleby, or The Formula," which in turn is a reading of Herman Melville's "Bartleby, the Scrivener: A Story of Wall Street" (I853). See Deleuze, Essays Critical and Clinical, 68-90.

59. Rancière, The Flesh of Words, I48.

6o. Cohen, Donde yo no estaba, 99.

6r. Ibid., 382.

62. Ibid., 323. 
63. Ibid., 54 .

64. Ibid., 3I4.

65. Ibid., 249.

66. Ibid., I3.

67. Braidotti, The Posthuman, 193.

68. Cohen, Donde yo no estaba, 355 .

69. Cohen, Buda, 69.

70. Ibid., 70-73.

7I. Deleuze, Spinoza, I25.

72. Cohen, Donde yo no estaba, 35 .

73. Ibid., I82.

74. Ibid., 68.

75. Ibid., 150.

76. Ibid., 94, I82.

77. Ibid., 95 .

78. Ibid., 4I5.

79. Ibid., 95 .

8o. Ibid., I82.

8I. Ibid., 530.

82. Braidotti, The Posthuman, $\mathrm{I} 37$.

83. Ibid., I07.

84. Cohen, Donde yo no estaba, 682.

85. See Braidotti, The Posthuman, 64; Braidotti, Metamorphoses, I79.

86. Alaimo and Hekman, "Introduction," 2.

87. Coole and Frost, "Introducing the New Materialisms," 25-26; the first citation is from Smith and Jenks, "Complexity, Ecology and the Materiality of Information," I47.

88. Colebrook, "On Not Becoming Man," 56.

89. Rancière, The Flesh of Words, I49.

\section{Chapter 6}

I. Jameson, Postmodernism, 284.

2. Freedman, Critical Theory and Science Fiction, 43.

3. Ibid., 44, I73.

4. Ibid., 43.

5. Jameson, Postmodernism, 284.

6. Jameson, Archaeologies of the Future, 6I.

7. Ibid., 345 .

8. Ibid., xiii.

9. Ibid., 288-89.

Io. Jameson, Postmodernism, 284.

II. Ibid., 286.

I2. Benjamin, "Theses on the Philosophy of History," 252. 
13. McQuire, Visions of Modernity, I3O-3I.

I4. Freedman, Critical Theory and Science Fiction, I6-23.

I5. Ibid., 53 .

I6. Adam, Time, i36.

17. Kriger, "Estrellas," 48.

I8. The phrase, meaning "god from the machine," originates in Horace's Ars Poetica and refers to the frequent use in Greek tragedies of a mechanical crane to lower actors playing gods onto the stage.

19. Jameson, Archaeologies of the Future, 293.

2o. Ibid., 308 .

2I. Coronil, "Beyond Occidentalism," 69-70.

22. Chakrabarty, Provincializing Europe, 7; see Marx, "Preface to the First Edition," 9I.

23. Jameson, The Seeds of Time, 27.

24. Ibid., I7.

25. Jameson, Postmodernism, 307.

26. Ibid., 309-IO.

27. Chakrabarty, Provincializing Europe, 7.

28. Jameson, Postmodernism, 20.

29. Adam, Time, II5.

30. The historical detail is fully accurate in this case, even down to the plaque on the dashboard that gives the place of construction as Kiev.

3I. This detail is not explicitly mentioned in the film but the in-joke would probably have been picked up by those viewers versed in military history.

32. Latour, We Have Never Been Modern, 75.

33. Serres and Latour, Conversations on Science, Culture, and Time, 45.

34. Jameson, Postmodernism, 309.

35. Lim, Translating Time, I6.

36. Manovich, The Language of New Media, I9I-92.

37. Rosen, Change Mummified, 309.

38. Manovich, The Language of New Media, 295.

39. Ibid., 302.

40. Ibid., 298-99.

4I. Latour, We Have Never Been Modern, 68.

42. Ibid., 69.

43. Serres and Latour, Conversations on Science, Culture, and Time, 60.

44. Ibid., 59.

45. Chakrabarty, Provincializing Europe, 7.

46. Jameson, Archaeologies of the Future, 216.

47. Ibid., 216, 293.

48. Ibid., 289 .

49. Ibid., 308.

50. Jameson, Postmodernism, I8.

5I. Jameson, Archaeologies of the Future, 263. 
52. Ibid.

53. For a meticulous account of such references, see Blos-Jáni, "Is Silence Hereditary?"

54. Marx, Capital, I:717-18.

55. Bruno, "Ramble City," 63-64.

56. Ibid., 65 .

57. Acosta Larose and Aponte A. Gutter, "En el comienzo estaba el ojo."

58. Ibid.

59. Cisneros, "Urban Imaginaries in Esteban Sapir’s La Antena," 197.

6o. Ibid., 195 .

6r. Ibid., 196.

62. Jenkins, Convergence Culture, I4.

63. Cartwright, "Film and the Digital in Visual Studies," 8.

64. Acosta Larroca and Aponte A. Gutter, "En el comienzo estaba el ojo."

65. Bolter and Grusin, "Remediation," 345.

66. One of the first shots of the futuristic Buenos Aires includes a number of recognizable buildings in the collage: on the right, the art deco Kavanagh building (1934), the first skyscraper in Latin America; in the center, the Usina Puerto Nuevo (1929-32). In a later shot, the curved facade (also art deco) of the Mercado del Abasto (I93I-34) looms unmistakably in the background.

67. The first use of this term was made by William Gibson in his short story "The Gernsback Continuum" (from Burning Chrome, 1982), to describe a film with the working title The Airstream Futuropolis: The Tomorrow That Never Was.

68. Grana, "Olvídate de mí."

69. Bergson, Time and Free Will, IoI.

70. Grosz, The Nick of Time, I73.

7I. Heise, Chronoschisms, 53.

72. Ibid., 7 .

73. La Valley, "Traditions of Trickery," I44, I48.

74. Ibid., I48-49.

75. García, "La sonámbula," I8.

76. The black-and-white sequences of the main narrative thread were originally shot using I6 mm color film, transferred to black-and-white digital video, and then to $35 \mathrm{~mm}$, resulting in a loss of quality that contrasts sharply with the rich color of Eva's visions. See ibid.; Félix-Didier and Peña, "La sonámbula [interview with Fernando Spiner]."

77. García, "La sonámbula," I8.

78. Jameson, Archaeologies of the Future, 256.

79. See, for example, Jameson, The Seeds of Time, 27.

80. Serres and Latour, Conversations on Science, Culture, and Time, 58.

81. Stiegler, Technics and Time 3, I5.

82. Heise, Chronoschisms, 38.

83. Stiegler, Technics and Time 3, II, I2.

84. Ibid., I2. 
85. Ibid., 77 .

86. Stiegler's argument concerning the cinematographic nature of consciousness is too complex to summarize in full here, but I refer the reader to his Technics and Time 3; see also Ertuna-Howison, "Review of Bernard Stiegler, Technics and Time, 3"; Crogan, "Essential Viewing."

87. Nowotny, Time, 3I.

88. Landsberg, "Prosthetic Memory," 176.

89. Stiegler, Technics and Time 3, 206.

90. Lim, Translating Time, II.

91. Doane, The Emergence of Cinematic Time, 5.

92. Ibid., Io.

93. Ibid., 9 .

94. Ibid., 22.

95. Jameson, The Seeds of Time, I5.

96. Ibid., I9.

97. Keightley, "Introduction: Time, Media, Modernity," I4.

98. Keightley, "Conclusion," 2OI-2.

99. Reading, "Globital Time," I52.

Ioo. Keightley, "Introduction," I4.

IOI. Stewart, "The 'Videology' of Science Fiction," I59, I6I.

I02. Ibid., I6I-62.

I03. Lim, Translating Time, II.

I04. Jameson, Postmodernism, 284.

I05. Landsberg, "Prosthetic Memory," I79, I78.

I06. Harvey, The Condition of Postmodernity, 323.

\section{Conclusion}

I. Hansen, Embodying Technesis, 4.

2. Ibid., 5-6.

3. Ibid., 8, 4 .

4. Ibid., 87.

5. James, The New French Philosophy, I2.

6. Barad, "Posthumanist Performativity," 139.

7. Hansen, Embodying Technesis, $23 \mathrm{I}$.

8. Benjamin, The Writer of Modern Life, 205, I9I.

9. See Benjamin, "On the Mimetic Faculty."

Io. Hansen, Embodying Technesis, 232.

II. Garrett and VanWieren, "A Conversation with Andrew Brown," I52.

I2. Bartra, Anthropology of the Brain, 6.

I3. Levine and Novoa, ;Darwinistas!, 47-48.

I4. Ezcurra, En el siglo XXX, 39.

I5. Levine and Novoa, „Darwinistas!, 48.

I6. Moore, "Adapt and Smile or Die!," I8. 
17. Malabou, What Should We Do with Our Brain?, I2.

I8. Ibid., 65, 68.

19. Hansen, Embodying Technesis, 68.

2o. Sinnerbrink, "Culture Industry Redux."

2I. Ibid. 


\section{Bibliography}

Abraham, Luis Emilio. "La difícil tarea de no representar: Entrevista a Rafael Spregelburd." Archivo Virtual: Artes Escénicas, 2007. http://artesescenicas.uclm.es/ index.php?sec=texto\&id $=65$.

Abraham, Luis Emilio. "Un teatro al acecho de la complejidad de lo real: Rafael Spregelburd y su poética en proceso." Archivo virtual: Artes Escénicas, 2007. http://artesescenicas.uclm.es/index.php?sec=texto\&id=380.

Acosta Larroca, Pablo, and Nicolás Aponte A. Gutter. "En el comienzo estaba el ojo: Entrevista a Esteban Sapir." GrupoKane, November 2007. http://www.grupokane.com.ar/index.php?option=com_content\&view=article\&id=74\%3Aartentr evestebansapir\&catid $=36 \% 3$ Acatficcion\&Itemid $=29$.

Adam, Barbara. Time. Cambridge: Polity Press, 2004.

Adorno, Theodor W. The Culture Industry: Selected Essays on Mass Culture. New York: Routledge, 20oI.

Ahrens, Jörn, and Arno Meteling. "Introduction." In Comics and the City: Urban Space in Print, Picture, and Sequence, edited by Jörn Ahrens and Arno Meteling, I-I6. New York: Continuum, 20 oro.

Aira, César. El juego de los mundos (novela de ciencia ficción). La Plata, Buenos Aires: El Broche, 2006.

Aira, César. Las curas milagrosas del Doctor Aira. Buenos Aires: Simurg, 1998.

Alaimo, Stacy, and Susan Hekman. "Introduction: Emerging Models of Materiality in Feminist Theory." In Material Feminisms, edited by Stacy Alaimo and Susan Hekman, I-19. Bloomington: Indiana University Press, 2008.

Alberdi, Juan Bautista. "Gobernar es poblar." In Bases y puntos de partida para la organización política de la República de Argentina, I6-24. Barcelona: Red Ediciones, 2016.

Arlt, Roberto. Notas sobre el cinematógrafo. Buenos Aires: Simurg, 1997.

Balzer, Jens. "'Hully Gee, I'm a Hieroglyph': Mobilizing the Gaze and the Invention of Comics in New York City, I895." In Comics and the City: Urban Space in Print, 
Picture, and Sequence, edited by Jörn Ahrens and Arno Meteling, 19-3I. New York: Continuum, 2010.

Barad, Karen. "Posthumanist Performativity: Toward an Understanding of How Matter Comes to Matter." In Material Feminisms, edited by Stacy Alaimo and Susan Hekman, I2O-54. Bloomington: Indiana University Press, 2008.

Barreiro, Ricardo, and Juan Giménez. Ciudad. Buenos Aires: Ediciones de la Urraca, 1992.

Barreiro, Ricardo, and Eduardo Risso. Caín. Barcelona: Norma Editorial, 2005.

Barreiro, Ricardo, and Francisco Solano López. Slot-Barr. Buenos Aires: Colihue, 2009.

Bartra, Roger. Anthropology of the Brain: Consciousness, Culture, and Free Will. Cambridge: Cambridge University Press, 2014.

Baudrillard, Jean. Simulacra and Simulation. Translated by Sheila Faria Glaser. Ann Arbor: University of Michigan Press, I994.

Baudrillard, Jean. "Simulacra and Simulations." In Selected Writings, edited by Mark Poster, I66-84. Stanford: Stanford University Press, I988.

Bellamy Foster, John. Marx's Ecology: Materialism and Nature. New York: Monthly Review Press, 2000. http://digamo.free.fr/marxecolo.pdf.

Benjamin, Walter. The Arcades Project. Translated by Howard Eiland and Kevin McLaughlin. Cambridge, MA: Belknap Press of Harvard University Press, 2002.

Benjamin, Walter. "On the Mimetic Faculty." In Selected Writings, vol. 2, I927-I934, edited by Michael William Jennings, Howard Eiland, and Gary Smith, translated by Rodney Livingstone, 720-22. Cambridge: Belknap Press of Harvard University Press, I999.

Benjamin, Walter. One-Way Street and Other Writings. Translated by J. A. Underwood. New York: Penguin Classics, 2009.

Benjamin, Walter. Selected Writings, vol. 2, part 2, I93I-I934. Edited by Michael William Jennings, Howard Eiland, and Gary Smith. Cambridge, MA: Belknap Press of Harvard University Press, 2005.

Benjamin, Walter. Selected Writings, vol. 3, I935-1938. Edited by Edmund Jephcott, Howard Eiland, and Michael W. Jennings. Cambridge, MA: Belknap Press of Harvard University Press, 2002.

Benjamin, Walter. "Theses on the Philosophy of History." In Illuminations, edited by Hannah Arendt, translated by Harry Zorn, 245-55. London: Pimlico, 1999.

Benjamin, Walter. The Writer of Modern Life: Essays on Charles Baudelaire. Edited by Michael William Jennings. Cambridge, MA: Harvard University Press, 2006.

Bergson, Henri. Time and Free Will. Translated by F. L. Pogson. London: George Allen and Unwin, I9ro.

Berone, Lucas. La fundación del discurso sobre la historieta en Argentina: De la "Operación Masotta" a un campo en dispersión. Córdoba: Universidad Nacional de Córdoba, 20II.

Bertens, Hans. The Idea of the Postmodern: A History. New York: Routledge, 1995. http://public.eblib.com/EBLPublic/PublicView.do?ptiID=179225.

Best, Steven, and Douglas Kellner. The Postmodern Turn. New York: Guilford Press, 1997. 
Bioy Casares, Adolfo. La invención de Morel. Madrid: Alianza, 1972.

Blaustein, Eduardo. Cruz diablo. Buenos Aires: Emecé, 1997.

Blos-Jáni, Melinda. "Is Silence Hereditary? Written Words and Acoustic Events in a Contemporary Silent Film: Esteban Sapir's La Antena (2007).” In Words and Images on the Screen: Language, Literature, Moving Pictures, edited by Agnes Petho, 132-58. Newcastle upon Tyne: Cambridge Scholars Publishing, 2008.

Bolter, J. David, and Richard A. Grusin. "Remediation.” Configurations 4, no. 3 (1996): 3II-58.

Borge, Jason. Avances de Hollywood: Critica cinematográfica en Latinoamérica, I9I5I945. Rosario: Beatriz Viterbo, 2005.

Borkenztain Szeiman, Bernardo. "Hermeneptalogía de Hieronymus Bosch: Poética de la complejidad." In La paranoia, by Rafael Spregelburd, 193-216. Bueno: Atuel, 2008.

Boscagli, Maurizia. Stuff Theory: Everyday Objects, Radical Materialism. New York: Bloomsbury, 20I4.

Bourdieu, Pierre. "The Intellectual Field: A World Apart." In In Other Words: Essays towards a Reflexive Sociology, translated by Matthew Adamson, I40-49. Cambridge: Polity Press, I990.

Bourdieu, Pierre. "The Uses of the People." In In Other Words: Essays towards a Reflexive Sociology, translated by Matthew Adamson, I50-55. Cambridge: Polity Press, 1990.

Bradbury, Ray. Fahrenheit 45I. London: HarperCollins, 2008.

Braidotti, Rosi. Metamorphoses: Towards a Materialist Theory of Becoming. Cambridge: Polity Press, 2002.

Braidotti, Rosi. The Posthuman. Cambridge: Polity Press, 2013.

Briante, Miguel. "La galera del tiempo." Página/ı2, November 26, I989.

Broderick, Damien. Reading by Starlight: Postmodern Science Fiction. New York: Routledge, I995.

Bruno, Giuliana. "Ramble City: Postmodernism and 'Blade Runner." October 4I (July 1987): 6I-74. http://dx.doi.org/10.2307/778330.

Bruno, Paula. Pioneros culturales de la Argentina: Biografías de una época, I860-I9I0. Buenos Aires: Siglo XXI, 2011.

Bukatman, Scott. Terminal Identity: The Virtual Subject in Postmodern Science Fiction. Durham: Duke University Press, 1993.

Caneto, Guillermo, Marcela Cassinelli, González Bergerot Héctor, César Maranghello, Elda Navarro, Alejandra Portela, and Susana Strugo. Historia de los primeros años del cine en la Argentina, I895-1910. Buenos Aires: Editorial Fundación Cinemateca Argentina, 1996.

Capanna, Pablo. Ciencia ficción: Utopía y mercado. Buenos Aires: Cántaro, 2007.

Capanna, Pablo. "Ciencia ficción criolla." In Escalera al cielo: Utopia y ciencia ficción, edited by Daniel Link, 47-49. Buenos Aires: La Marca, I994.

Cartwright, Lisa. "Film and the Digital in Visual Studies: Film Studies in the Era of Convergence." Journal of Visual Culture I, no. I (April 2002): 7-23. http://dx.doi. org/10.1177/147041290200100102. 
Cazaux, Diana. Historia de la divulgación cientifica en la Argentina. Buenos Aires: Teseo, 2010.

Chakrabarty, Dipesh. Provincializing Europe: Postcolonial Thought and Historical Difference. Princeton: Princeton University Press, 2008.

Christiansen, Hans-Christian. "Comics and Film: A Narrative Perspective." In Comics and Culture: Analytical and Theoretical Approaches to Comics, edited by HansChristian Christiansen and Anne Magnussen, I07-2I. Copenhagen: Museum Tusculanum Press, University of Copenhagen, 2000.

Cisneros, James. "Urban Imaginaries in Esteban Sapir's La Antena." In Filme in Argentinien / Argentine Cinema, edited by Daniela Ingruber and Ursula Prutsch, I9I-205. Berlin: Lit Verlag, 2012.

Clark, Andy. Natural-Born Cyborgs: Minds, Technologies, and the Future of Human Intelligence. New York: Oxford University Press, 2003.

Cohen, Marcelo. Buda. Barcelona: Lumen, I990.

Cohen, Marcelo. Donde yo no estaba. Buenos Aires: Norma, 2006.

Cohen, Marcelo. "Variedades." In Hombres amables, 7-I42. Buenos Aires: Norma, 1998.

Colebrook, Claire. Gilles Deleuze. New York: Routledge, $200 \mathrm{I}$

Colebrook, Claire. "On Not Becoming Man: The Materialist Politics of Unactualized Potential." In Material Feminisms, edited by Stacy Alaimo and Susan Hekman, 52-84. Bloomington: Indiana University Press, 2008.

Conti, Haroldo. "Compartir las luchas del pueblo." In Revista Crisis, 1973-1976: Antología del intelectual comprometido al intelectual revolucionario, edited by María Sonderéguer, 534-39. Bernal: Universidad Nacional de Quilmes, 2008.

Coole, Diana, and Samantha Frost. "Introducing the New Materialisms." In New Materialisms: Ontology, Agency, and Politics, edited by Diana Coole and Samantha Frost, I-43. Durham: Duke University Press, 2010.

Coronil, Fernando. "Beyond Occidentalism: Toward Nonimperial Geohistorical Categories." Cultural Anthropology II, no. I (February I996): 5I-87.

Cortiñas, Sergi. "Un recorrido por la historia del libro de divulgación científica." Quark 37-38 (2006): 54-68.

Crash Solomonoff, Pablo. "Eduardo Holmberg: Eslabón perdido en Marte." In Viaje maravilloso del señor Nic-Nac al planeta Marte, by Eduardo Ladislao Holmberg, II-25. Buenos Aires: Biblioteca Nacional / Colihue, 2006.

Crogan, Patrick. "Essential Viewing [review of Bernard Stiegler, La Technique et Le Temps 3: Le Temps Du Cinéma et La Question Du Mal-Etre]." Film Philosophy го, no. 2 (September 2006): 39-54.

Dabove, Juan Pablo. Nightmares of the Lettered City: Banditry and Literature in Latin America, I816-1929. Pittsburgh: University of Pittsburgh Press, 2007.

Daulte, Javier. “4D Óptico.” In Teatro, 49-175. Buenos Aires: Corregidor, 2010.

Daulte, Javier. "Juego y compromiso: Una afirmación contra la riña entre lo lúdico y lo comprometido en el teatro.” Teatro XXI: Revista del GETEA 7, no. I3 (200I): I3-I8.

De Landa, Manuel. "Emergence, Causality and Realism.” In The Speculative Turn: 
Continental Materialism and Realism, edited by Levi Bryant, Nick Srnicek, and Graham Harman, 38I-92. Melbourne: re.press, 201 .

Deleuze, Gilles. Essays Critical and Clinical. Translated by Daniel W. Smith and Michael A. Greco. London: Verso, 1998.

Deleuze, Gilles. The Fold: Leibniz and the Baroque. Translated by Tom Conley. London: Continuum, 2006.

Deleuze, Gilles. Spinoza: Practical Philosophy. Translated by Robert Hurley. San Francisco: City Lights Books, 1988.

Deleuze, Gilles, and Michel Foucault. "Intellectuals and Power." In Michel Foucault, Language, Counter-memory, Practice: Selected Essays and Interviews, . edited by Donald F. Bouchard, translated by Donald F. Bouchard and Sherry Simon, 205-17. Oxford: Blackwell, 1977.

De los Ríos, Valeria. Espectros de luz: Tecnologías visuales en la literatura latinoamericana. Santiago: Cuarto Propio, 201 .

Derrida, Jacques. Of Grammatology. Translated by Gayatri Chakravorty Spivak. Baltimore: Johns Hopkins University Press, 1997.

De Santis, Pablo. La historieta en la edad de la razón. Buenos Aires: Paidós, 1998.

De Toro, Alfonso. "Breves reflexiones sobre el concepto de lo fantástico de Bioy Casares en La invención de Morel y Plan de evasión: Hacia la literatura medialvirtual." In Homenaje a Adolfo Bioy Casares: Una retrospectiva de su obra, edited by Alfonso De Toro and Susanna Regazzoni, 135-55. Madrid: Vervuert Verlag, 2002.

Doane, Mary Ann. The Emergence of Cinematic Time: Modernity, Contingency, the Archive. Cambridge, MA: Harvard University Press, 2002.

Dolphijn, Rick, and Iris Van der Tuin, eds. New Materialism: Interviews and Cartographies. Ann Arbor, MI: Open Humanities Press, 20I2. http://openhumanities press.org/new-materialism.html.

Drucaroff, Elsa. "Narraciones de la intemperie: Sobre El año del desierto de Pedro Mairal y otras obras argentinas recientes." El interpretador: Literatura, arte y pensamiento 27 (June 2006). http://www.elinterpretador.com.ar/27ElsaDrucaroffNarracionesDeLaIntemperie.html.

Dubatti, Jorge. Filosofia del teatro I: Convivio, experiencia, subjetividad. Buenos: Atuel, 2007.

Dubatti, Jorge. "Hacia una relectura post-postmoderna del teatro argentino: Notas sobre Rafael Spregelburd.” Nuestra América: Revista de Estudios sobre la Cultura Latinoamericana 2 (December 2006): I7I-8I.

Dubatti, Jorge. "Nota epilogal." In Rafael Spregelburd, La estupidez. El pánico. Heptalogía de Hieronymus Bosch, 65-67. Buenos Aires: Atuel, 2004.

Enns, Jörn. "The City as Archive in Jason Lutes's Berlin." In Comics and the City: Urban Space in Print, Picture, and Sequence, edited by Jörn Ahrens and Arno Meteling, 45-59. New York: Continuum, 2010.

Ertuna-Howison, Irmak. "Review of Bernard Stiegler, Technics and Time, 3: Cinematic Time and the Question of Malaise." Philosophy in Review 32, no. 2 (2012): I $42-44$. 
Evans, Arthur B. "Nineteenth-Century SF." In The Routledge Companion to Science Fiction, edited by Mark Bould, Andrew M. Butler, Adam Roberts, and Sherryl Vint, 13-22. New York: Routledge, 2009. http://search.ebscohost.com/login.asp $\mathrm{x}$ ? direct=true \&scope $=$ site $\& \mathrm{db}=$ nlebk\&db=nlabk\&AN=270716.

Ezcurra, Eduardo de. En el siglo XXX. Buenos Aires: Juan A. Alsina, I89I.

Félix-Didier, Paula, and Fernando Martín Peña. "La sonámbula [interview with Fernando Spiner].” Cineclub Núcleo, August II, I998, 2-3.

Fernández, Laura Cristina, and Sebastian Gago. "Al que le quepa la escafandra que se la ponga: La (re)construcción del relato político peronista a partir de $E l$ Eternauta." In Creencias bien fundadas: Historieta y politica en Argentina, de la transición democrática al kirchnerismo, edited by Lucas Berone and Federico Reggiani, 62-75. Córdoba: Universidad Nacional de Córdoba, 2012.

Flammarion, Camille. La pluralidad de los mundos habitados. Madrid: Gaspar y Roig, I873.

Flammarion, Camille. Los mundos imaginarios y los mundos reales. Madrid: Gaspar y Roig, I873.

Flammarion, Camille. Lumen. Madrid: Gaspar y Roig, I874.

Foucault, Michel. "The Concern for Truth." In Politics, Philosophy, Culture: Interviews and Other Writings, I977-I984, edited by Lawrence D. Kritzman, 255-67. New York: Routledge, 1988.

Foucault, Michel. The History of Sexuality. Translated by Robert Hurley. Vol. I. New York: Pantheon Books, I978.

Foucault, Michel. "Truth and Power." In The Foucault Reader, edited by Paul Rabinow, 5I-75. New York: Pantheon Books, 1984.

Frahm, Ole. "Weird Signs: Comics as Means of Parody." In Comics and Culture: Analytical and Theoretical Approaches to Comics, edited by Hans-Christian Christiansen and Anne Magnussen, I77-9I. Copenhagen: Museum Tusculanum Press, University of Copenhagen, 2000.

Fraser, Benjamín, and Claudia Méndez. "Espacio, tiempo, ciudad: La representación de Buenos Aires en El Eternauta (1957-1959) de Héctor Germán Oesterheld." Revista Iberoamericana 78, no. 238 (May 3I, 20I2): 57-72. http://dx.doi. org/10.5195/reviberoamer.2012.6887.

Frederick, Bonnie. "A State of Conviction, a State of Feeling: Scientific and Literary Discourses in the Works of Three Argentine Writers, I879-1908." Latin American Literary Review I9, no. 38 (December 199I): 48-6I.

Freedman, Carl Howard. Critical Theory and Science Fiction. Hanover, NH: Wesleyan University Press, 2000.

Friera, Silvina. “'Me gustó trabajar con la paranoia de la clase media' [interview with Pedro Mairal].” Página/I2, December I2, 2005, sec. Cultura y espectáculos. http:// www.pagina12.com.ar/diario/suplementos/espectaculos/4-1263-2005-12-12. html.

Fukuyama, Francis. The End of History and the Last Man. New York: Free Press, 1992. Gamerro, Carlos. Ficciones barrocas: Una lectura de Borges, Bioy Casares, Silvina Ocampo, Cortázar, Onetti y Felisberto Hernández. Buenos Aires: Eterna Cadencia, 2010. 
Gandolfo, Elvio E. El libro de los géneros: Ciencia ficción, policial, fantasía, terror. Buenos Aires: Grupo Editorial Norma, 2007.

García Canclini, Néstor. Imaginarios urbanos. Buenos Aires: Eudeba, 1997.

García, José Luis. “La sonámbula.” Revista $A D F$ 2, no. 2 (Summer 1999): I8.

García, Mariano. Degeneraciones textuales: Los géneros en la obra de César Aira. Rosario: Beatriz Viterbo Editora, 2006.

García, Martín. "El eternauta, la zona de exclusión y la democracia.” Fierro: Historietas para sobrevivientes I, no. 2 (October 1984): 33-36.

Gardner, Jared. "Archives, Collectors, and the New Media Work of Comics." Modern Fiction Studies 52, no. 4 (2006): 787-806.

Garrett, Victoria, and Rachel VanWieren. "A Conversation with Andrew Brown: Mashing Up Latin American Literature, Science, Technology, and the Posthuman." Mester 39, no. I (2010): 149-60.

Gasparini, Sandra. Espectros de la ciencia: Fantasias cientificas de la Argentina del siglo XIX. Buenos Aires: Santiago Arcos, 2012.

Gasparini, Sandra. "La fantasía científica: Un género moderno." In El brote de los géneros, edited by Alejandra Laera, II9-47. Historia crítica de la literatura argentina 3. Buenos Aires: Emecé, 2010.

Germain, Gilbert. "The Human Condition in the Age of Technology." In Globalization, Technology, and Philosophy, edited by David Edward Tabachnick and Toivo Koivukoski, 159-74. Albany: State University of New York Press, 2004. http:// search.ebscohost.com/login.aspx? direct $=$ true $\&$ scope $=$ site $\& \mathrm{db}=$ nlebk $\& \mathrm{db}=$ nlab $\mathrm{k} \& \mathrm{AN}=143140$.

Gilloch, Graeme. Myth and Metropolis: Walter Benjamin and the City. Cambridge: Polity Press, 1996.

Gilman, Claudia. Entre la pluma y el fusil: Debates y dilemas del escritor revolucionario en América Latina. Buenos Aires: Siglo XXI, 2003.

Gociol, Judith, and Diego Rosemberg. La historieta argentina. Buenos Aires: Ediciones de la Flor, 2000.

Goldstein, Miriam. "Artistas e intelectuales argentinos ante 'La quimera del . . . cine." In Intelectuales, escritores e industria cultural en la Argentina (I898-1933), edited by Eduardo Romano, 389-4I4. Buenos Aires: La Crujía, 2012.

Gorriti, Juana Manuela. “Quien escucha su mal oye.” In Cuentos fantásticos argentinos del siglo XIX, edited by Carlos Abraham, 65-74. Madrid: Biblioteca del Laberinto, 2013.

Gould, Stephen Jay. An Urchin in the Storm: Essays about Books and Ideas. London: Collins Harvill, 1988.

Grana, Dolores. "Olvídate de mí . . . : La sonámbula de Fernando Spiner." Página/I2: Radar, April I2, I998. http://www.pagina12.com.ar/1998/suple/radar/abril/9804-12/nota3_a.htm.

Gratzer, Walter. The Undergrowth of Science: Delusion, Self-Deception and Human Frailty. New York: Oxford University Press, 2000.

Groensteen, Thierry. Système de la bande dessinée. Paris: Presses Universitaires de France, 1999 . 
Groensteen, Thierry. The System of Comics. Jackson: University Press of Mississippi, 2007. http://site.ebrary.com/id/10436091.

Grosz, Elizabeth. The Nick of Time. Durham: Duke University Press, 2004.

Hansen, Mark. Embodying Technesis: Technology beyond Writing. Ann Arbor: University of Michigan Press, 2000.

Harvey, David. The Condition of Postmodernity. Oxford: Blackwell, I990.

Hayles, N. Katherine. How We Became Posthuman: Virtual Bodies in Cybernetics, Literature, and Informatics. Chicago: University of Chicago Press, I999.

Haywood Ferreira, Rachel. The Emergence of Latin American Science Fiction. Middletown, CT: Wesleyan University Press, $201 \mathrm{I}$.

Heise, Ursula K. Chronoschisms: Time, Narrative, and Postmodernism. Cambridge: Cambridge University Press, 1997.

Heredia, María Florencia. "El teatro de Javier Daulte o la pregunta por lo humano." In Javier Daulte, Teatro, I9-47. Buenos Aires: Corregidor, 2010.

Hernández, Marisa. "Entrevista: Rafael Spregelburd." Hispamérica 34, no. IO2 (December 2005): 4I-49.

Holmberg, Eduardo Ladislao. Dos partidos en lucha: Fantasía cientifica. Buenos Aires: Corregidor, 2005.

Holmberg, Eduardo Ladislao. "El Museo de Buenos Aires: Su pasado-su presente - su porvenir." El naturalista argentino I, no. 2 (February I878): 33-43.

Holmberg, Eduardo Ladislao. "El ruiseñor y el artista." In Penumbra: Antología crítica del cuento fantástico hispanoamericano del siglo XIX, edited by Lola López Martín, II3-29. Madrid: Ediciones Lengua de Trapo, 2006.

Holmberg, Eduardo Ladislao. "Horacio Kalibang o los autómatas." In Historias futuras: Antología de la ciencia ficción argentina, edited by Adriana Fernández and Edgardo Pígoli, 17-50. Buenos Aires, Argentina: Emecé Editores, 2000.

Holmberg, Eduardo Ladislao. Olimpio Pitango de Monalia. Edited by Gioconda Marún. Buenos Aires: Ediciones Solar, 1994.

Holmberg, Eduardo Ladislao. Viaje maravilloso del señor Nic-Nac al planeta Marte. Buenos Aires: Biblioteca Nacional / Colihue, 2006.

Hume, David. A Treatise of Human Nature. Project Gutenberg Ebook, 2003. http:// www.gutenberg.org/files/4705/4705-h/4705-h.htm.

Huyssen, Andreas. Present Pasts: Urban Palimpsests and the Politics of Memory. Stanford, CA: Stanford University Press, 2003.

James, Ian. The New French Philosophy. Cambridge: Polity Press, 2012.

Jameson, Fredric. Archaeologies of the Future: The Desire Called Utopia and Other Science Fictions. London: Verso, 2005.

Jameson, Fredric. Postmodernism; Or, the Cultural Logic of Late Capitalism. London: Verso, 1991.

Jameson, Fredric. The Seeds of Time. New York: Columbia University Press, 2004.

Jenkins, Henry. Convergence Culture: Where Old and New Media Collide. New York: New York University Press, 2006.

Jürs-Munby, Karen. "Introduction.” In Hans-Thies Lehmann, Postdramatic Theatre, I-I5. New York: Routledge, 2006.

Kantaris, Geoffrey. "Cyborgs, Cities, and Celluloid: Memory Machines in Two 
Latin American Cyborg Films." In Latin American Cyberculture and Cyberliterature, edited by Thea Pitman and Claire Taylor, 50-69. Liverpool: Liverpool University Press, 2007.

Keightley, Emily, ed. "Conclusion: Making Time-the Social Temporalities of Mediated Experience." In Time, Media and Modernity, 20I-23. New York: Palgrave Macmillan, 2012.

Keightley, Emily. "Introduction: Time, Media, Modernity." In Time, Media and Modernity, edited by Emily Keightley, I-22. New York: Palgrave Macmillan, 2012.

King, Edward. Science Fiction and Digital Technologies in Argentine and Brazilian Culture. New York: Palgrave Macmillan, 20I3.

Kriger, Clara. "Estrellas." In Miradas desinhibidas: El nuevo documental iberoamericano, 2000-2008, edited by Paulo Antonio Paranaguá, 44-49. Madrid: Sociedad Estatal de Conmemoraciones Estatales, 2009.

Kuntscher, Leonardo, and Santiago Miret. El maravilloso viaje del señor Nic-Nac. Vol. I. Buenos Aires: Anexia, 2012.

Laera, Alejandra. "Introducción." In El brote de los géneros, edited by Alejandra Laera, 7-I2. Buenos Aires: Emecé, 2010.

Laera, Alejandra. "Novelas argentinas (circulación, debates y escritores en el último cuarto del siglo XIX).” In El brote de los géneros, edited by Alejandra Laera, 95II8. Buenos Aires: Emecé, 2010.

Landsberg, Alison. "Prosthetic Memory: Total Recall and Blade Runner." Body and Society I, nos. 3-4 (I995): I75-89.

Latour, Bruno. We Have Never Been Modern. Cambridge, MA: Harvard University Press, 1993.

La Valley, Albert J. "Traditions of Trickery: The Role of Special Effects in the Science Fiction Film." In Shadows of the Magic Lamp: Fantasy and Science Fiction in Film, edited by George Edgar Slusser and Eric S. Rabkin, I4I-58. Carbondale: Southern Illinois University Press, 1985.

Le Bon, Gustave. Psicología de las masas. Translated by Alfredo Guera Miralles. 3rd ed. Madrid: Ediciones Morata, 1995.

Lemmens, Pieter. “'This System Does Not Produce Pleasure Anymore': An Interview with Bernard Stiegler." Krisis: Journal for Contemporary Philosophy I (2011): 33-4I.

Levine, Alex, and Adriana Novoa. ;Darwinistas! The Construction of Evolutionary Thought in Nineteenth-Century Argentina. Leiden: Brill, 2012.

Lim, Bliss Cua. Translating Time: Cinema, the Fantastic, and Temporal Critique. Durham: Duke University Press, 2009.

Mairal, Pedro. El año del desierto. Buenos Aires: Interzona, 2005.

Malabou, Catherine. Plasticity at the Dusk of Writing: Dialectic, Destruction, Deconstruction. Translated by Caroline Shread. New York: Columbia University Press, 2010.

Malabou, Catherine. What Should We Do with Our Brain? Translated by Sebastian Rand. New York: Fordham University Press, 2008.

Manovich, Lev. The Language of New Media. Cambridge, MA: MIT Press, 2007.

Marx, Karl. Capital: A Critique of Political Economy. Translated by Ben Fowkes. Vol. I. London: Penguin, 1990. 
Marx, Karl. Early Writings. Translated by T. B. Bottomore. London: C.A. Watts, 1963.

Marx, Karl. Grundrisse: Foundations of the Critique of Political Economy. Translated by Martin Nicolaus. London: Penguin Classics, 1993.

Marx, Karl. "Preface to the First Edition." In Capital, translated by Ben Fowkes, I:89-93. London: Penguin, 1990.

McCloud, Scott. Understanding Comics: The Invisible Art. New York: Harper Perennial, I994.

McLuhan, Marshall. The Medium Is the Massage. New York: Random House, 1967.

McQuire, Scott. Visions of Modernity: Representation, Memory, Time and Space in the Age of the Camera. London: Sage Publications, 1998.

Moore, Gerald. "Adapt and Smile or Die! Stiegler among the Darwinists." In Stiegler and Technics, edited by Christina Howells and Gerald Moore, I7-33. Edinburgh: Edinburgh University Press, 20I3.

Morin, Edgar. The Cinema; or The Imaginary Man. Translated by Lorraine Mortimer. Minneapolis: University of Minnesota Press, 2005.

Nora, Pierre. "Between Memory and History: Les Lieux de Mémoire." Representations 26 (Spring 1989): 7-24.

Nowotny, Helga. Time: The Modern and Postmodern Experience. Cambridge: Polity Press, 1996.

Oesterheld, Héctor G. "El pueblo echa al invasor inglés." In Latinoamérica y el imperialismo: 450 años de guerra, edited by Héctor G. Oesterheld and Leopoldo Durañona, n.p. Buenos Aires: Doeyo y Viniegra, 2004.

Oesterheld, Héctor G., and Francisco Solano López. El Eternauta: 1957-2007, 50 años. Buenos Aires: Doedytores, 2006.

Oesterheld, Héctor G., and Francisco Solano López. El Eternauta II. Buenos Aires: Doedytores, 2007.

Page, Joanna. Creativity and Science in Contemporary Argentine Literature. Calgary: University of Calgary Press, 20I4.

Pagés Larraya, Antonio. "Estudio preliminar." In Cuentos fantásticos, by Eduardo Ladislao Holmberg, 7-98. Buenos Aires: Hachette, 1957.

Parrinder, Patrick. "Introduction: Learning from Other Worlds." In Learning from Other Worlds: Estrangement, Cognition and the Politics of Science Fiction and Utopia, edited by Patrick Parrinder, I-I6. Liverpool: Liverpool University Press, 2000.

Pérez Rasetti, Carlos. "La locura lúcida: Ficción, ciencia y locura en las fantasías científicas de Holmberg." In Literatura argentina: Perspectivas de fin de siglo, edited by María Celia Vázquez and Sergio Pastormerlo, 207-26. Buenos Aires: Eudeba, 200I. http://www.samizdat.com.ar/samizdat20/S20-51\%20-\%20Edu ardo\%20Holmberg\%20-\%20La\%20locura\%20lucida.htm.

Pfister, Manfred. "How Postmodern Is Intertextuality?" In Intertextuality, edited by Heinrich F. Plett, 207-24. New York: W. de Gruyter, I991.

Pinedo, Rafael. Plop. Buenos Aires: Interzona, 2004.

Quereilhac, Soledad. La imaginación cientifica: Ciencias ocultas y literatura fantástica 
en el Buenos Aires de entresiglos (I875-1910). Buenos Aires: Universidad de Buenos Aires / CONICET / Instituto de Historia Argentina y Americana "Dr. Emilio Ravignani,” 20I5. http://www.ravignanidigital.com.ar/tms/series/tesis_ravig/ltr005-tesis-quereilhac-2010.pdf.

Quiroga, Horacio. Cine y literatura. Buenos Aires: Losada, 2007.

Quiroga, Horacio. "El espectro." In Cuentos completos, I:477-84. Montevideo: Ediciones de la Plaza, 1987.

Quiroga, Horacio. "El puritano.” In Más allá, 78-85. Buenos Aires: Losada, 1954. Quiroga, Horacio. "El vampiro.” In Más allá, I8-43. Buenos Aires: Losada, 1954.

Rancière, Jacques. The Flesh of Words: The Politics of Writing. Translated by Charlotte Mandell. Stanford: Stanford University Press, 2004.

Reading, Anna. "Globital Time: Time in the Digital Globalised Age." In Time, Media and Modernity, edited by Emily Keightley, I43-62. New York: Palgrave Macmillan, 2012.

Reati, Fernando O. Postales del porvenir: La literatura de anticipación en la Argentina neoliberal (1985-1999). Buenos Aires: Editorial Biblos, 2006.

Ricoeur, Paul. Freud and Philosophy: An Essay on Interpretation. Translated by Denis Savage. New Haven: Yale University Press, I970.

Rivera, Jorge B. "Prólogo.” In Roberto Arlt, Notas sobre el cinematógrafo, 7-15. Buenos Aires: Simurg, 1997.

Rocca, Pablo. "Horacio Quiroga ante la pantalla." Anales de Literatura Hispanoamericana 32 (2003): 27-36.

Rodríguez, Julia. Civilizing Argentina: Science, Medicine, and the Modern State. Chapel Hill: University of North Carolina Press, 2006.

Rodríguez Pérsico, Adriana. "'Las reliquias del banquete’ darwinista: E. Holmberg, escritor e cientifico." MLN II6, no. 2 (March 200I): 37I-9I.

Rodríguez Pérsico, Adriana. Relatos de época: Una cartografía de América Latina, I880-1920. Rosario: Beatriz Viterbo, 2008.

Rosen, Philip. Change Mummified: Cinema, Historicity, Theory. Minneapolis: University of Minnesota Press, $200 I$.

Rubione, Alfredo V. E. "H. G. Oesterheld: Géneros erráticos y avatares de la fícción.” In Jornadas Internacionales de Literatura Argentina / Comparatistica: Actas, 22934. Buenos Aires: Facultad de Filosofía y Letras, Universidad de Buenos Aires, I995.

Sarlo, Beatriz. La imaginación técnica: Sueños modernos de la cultura argentina. Buenos Aires: Nueva Visión, 1992.

Sarlo, Beatriz. Tiempo pasado: Cultura de la memoria y giro subjetivo. Una discusión. Buenos Aires: Siglo XXI, 2005.

Sarlo, Beatriz. Una modernidad periférica: Buenos Aires, I920 y 1930. Buenos Aires: Ediciones Nueva Visión, I988.

Sarmiento, Domingo F. Facundo: Civilización y barbarie. Madrid: Alianza, I988.

Sasturain, Juan. El domicilio de la aventura. Buenos Aires: Ediciones Colihue, 1995.

Schmídel, Ulrich. Viaje al río de la Plata, I534-I554. Translated by Samuel Alejandro Lafone Quevedo. Alicante: Biblioteca Virtual Miguel de Cervantes, 200I. http:// 
www.cervantesvirtual.com/obra-visor/viaje-al-rio-de-la-plata-1534-1554/ $\mathrm{html} /$.

Semilla Durán, María A. "El Apocalipsis como deconstrucción del imaginario histórico en El año del desierto de Pedro Mairal." In Los imaginarios apocalípticos en la literatura hispanoamericana contemporánea, edited by Geneviève Fabry, Ilse Logie, and Pablo Decock, 327-43. Berlin: Peter Lang, 2010.

Serres, Michel, and Bruno Latour. Conversations on Science, Culture, and Time. Translated by Roxanne Lapidus. Ann Arbor: University of Michigan Press, I995.

Sigal, Silvia. Intelectuales y poder en la década del sesenta. Buenos Aires: Puntosur, I99I.

Silva, Pablo. "H. G. O.: Entrevista a Víctor Bailo y Daniel Stefanello.” October 22, 200I. http://www.leedor.com/contenidos/cine/h-g-o.

Simmel, Georg. "The Metropolis and Mental Life." In On Individuality and Social Forms: Selected Writings, edited by Donald N. Levine, 324-39. Chicago: University of Chicago Press, I97I.

Sinnerbrink, Robert. "Culture Industry Redux: Stiegler and Derrida on Technics and Cultural Politics." Transformations i7 (2009). http://www.transformations journal.org/journal/issue_17/article_05.shtml.

Smith, John, and Chris Jenks. "Complexity, Ecology and the Materiality of Information." Theory, Culture and Society 22, no. 5 (October I, 2005): I4I-63. http:// dx.doi.org/10.1177/0263276405057048.

Spregelburd, Rafael. La paranoia. Bueno: Atuel, 2008.

Spregelburd, Rafael. "Respuestas a las preguntas de Jorge Dubatti para la edición de La paranoia." In La paranoia, I5I-77. Bueno: Atuel, 2008.

Steimberg, Alejo. "El discurso más allá de las palabras, o el análisis ideológico de historietas: Lecturas de El eternauta y Slot-Barr." Camouflage Comics: Dirty War Images, n.d. http://www.camouflagecomics.com/pdf/04_steimberg_es.pdf.

Sterelny, Kim. The Evolved Apprentice: How Evolution Made Humans Unique. Cambridge, MA: MIT Press, 2012.

Stewart, Garrett. "The 'Videology' of Science Fiction." In Shadows of the Magic Lamp: Fantasy and Science Fiction in Film, edited by George Edgar Slusser and Eric S Rabkin, I59-207. Carbondale: Southern Illinois University Press, I985.

Stiegler, Bernard. Acting Out. Translated by David Barison, Daniel Ross, and Patrick Crogan. Stanford: Stanford University Press, 2009.

Stiegler, Bernard. Technics and Time I: The Fault of Epimetheus. Translated by Richard Beardsworth and George Collins. Stanford: Stanford University Press, 1998.

Stiegler, Bernard. Technics and Time 2: Disorientation. Translated by Richard Barker. Stanford: Stanford University Press, 2009.

Stiegler, Bernard. Technics and Time 3: Cinematic Time and the Question of Malaise. Translated by Stephen Barker. Stanford: Stanford University Press, 2011.

Stiegler, Bernard. "Within the Limits of Capitalism, Economizing Means Taking Care.” Ars Industrialis, n.d. http://arsindustrialis.org/node/2922.

Suhr, André. "Seeing the City through a Frame: Marc-Antoine Mathieu's Acquefacques Comics." In Comics and the City: Urban Space in Print, Picture, and 
Sequence, edited by Jörn Ahrens and Arno Meteling, 23I-46. New York: Continuum, 2010.

Terán, Oscar. De utopias, catástrofes y esperanzas: Un camino intelectual. Buenos Aires: Siglo XXI, 2006.

Terán, Oscar. "Ideas e intelectuales en la Argentina." In Ideas en el siglo: Intelectuales y cultura en el siglo XX latinoamericano, edited by Oscar Terán, I3-95. Buenos Aires: Siglo XXI, 2004.

Terán, Oscar. Vida intelectual en el Buenos Aires de fin-de-siglo (I880-I9I0): Derivas de la cultura cientifica. Buenos Aires: Fondo de Cultura Económica, 2000.

Vanasco, Alberto. "Post-Bombum." In Memorias del futuro, I37-43. Buenos Aires: Torres Agüero Editor, 1986.

Van Camp, Nathan. "From Biopower to Psychopower: Bernard Stiegler's Pharmacology of Mnemotechnologies.” Ctheory, May 9, 20I2. http://www.ctheory.net/ articles.aspx?id=706.

Von Sprecher, Roberto. "Discurso montonero en las historietas de Héctor Germán Oesterheld." In Héctor Germán Oesterheld: De "El Eternauta" a Montoneros, edited by Roberto Von Sprecher and Federico Reggiani, 49-62. Córdoba: Universidad Nacional de Córdoba, 20 Io.

Waugh, Patricia. Metafiction: The Theory and Practice of Self-Conscious Fiction. New York: Methuen, I984.

Wolfe, Gary K. The Known and the Unknown: The Iconography of Science Fiction. Kent, OH: Kent State University Press, I979.

Zimmer, Zac. "A Year in Rewind, and Five Centuries of Continuity: El Año Del Desierto's Dialectical Image.” $M L N$ I28, no. 2 (2013): 373-83. http://dx.doi. org/10.1353/mln.2013.0019.

Zimmer, Zac. "Barbarism in the Muck of the Present: Dystopia and the Postapocalyptic from Pinedo to Sarmiento." Latin American Research Review 48, no. 2 (20I3): I3I-47. 



\section{Index}

Adam, Barbara, I58, I66

adaptation, 43, 97

versus adoption, 93, 95, 104, 195-96

Adiós querida luna, I54

Adorno, Theodor W., I08, I2I, I28

Agresti, Alejandro, I54

Ahrens, Jörn, 54-55

Aira, César, 6, I4, I3I

Las curas milagrosas del Doctor Aira, $207 \mathrm{n} 73$

El juego de los mundos, 9-IO, I08, II9-30, 194, 196

Alberdi, Juan Bautista, 22

"Aleph, El," 59

"Aliens, The," 73-74

año del desierto, El, 8-9, 82-84, 88-96, I04-5, 194-95

antena, La, 6, II, I3, I55, I7I-79, I83, I88-9I

apprentice learning. See Sterelny, Kim

archive: comic medium as, 8, 53, 68-7I, $76-78$

Arlt, Roberto, 35, 92-93, I09-IO, I29, $204 \mathrm{n} 28$

Artaud, Antonin, I4I

Asimov, Isaac, 7I-72

Automáticos, $\mathrm{I} 34$
Balzer, Jens, 53, 55, 64

Barad, Karen, 193

Barreiro, Ricardo, 7-8, 53-54, 80

Cain, 8, 56, 64-68, 202n2o

Ciudad, 8, 56-64, 66, 68, 74, 76ni3, 79, 202ni9

Ministerio, 8, 5I, 52f, 56, 62, 70-7I, 74, 76-77, 20InI

Parque Chas, 78

Slot-Barr, 8, 69, 7I-73, 77-79, $202 n 45$

Bartra, Roger, 95, 194

Baudrillard, Jean, I3, II5, I2I, I46

becoming imperceptible, I5I

becoming other, 145

Bellamy Foster, John, I2

Benjamin, Walter

on the archive, 69, 76, 79

critique of historicism, II, I56-57, I70, I9I

materialism, I3-I4, I93

on the modern city, $8,53-56,60$,

$$
64-65,80,92
$$

Bergson, Henri, I80-8I, I87

Bertens, Hans, 53

"biblioteca de Babel, La," 73

biopower, 98 
Bioy Casares, Adolfo, I, I28-3I, I54 "En memoria de Paulina," II5-I6 La invención de Morel, 6, 9, I07, II4-I9

Blade Runner, I75, I79, 190

Blaustein, Eduardo, 6, I4, 194

Cruz diablo, 8-9, 82-84, 96-105, 195-96

Bolter, J. David, I79

Borge, Jason, I09

Borges, Jorge Luis, 54, 59, 73, 78, I54$55, \mathrm{I} 82$

"El Aleph," 59

"La biblioteca de Babel," 73

"Fundación mítica de Buenos Aires," 90-9I

"El Golem," I34

"El inmortal," I22

"El jardín de senderos que se bifurcan," 73

"Las ruinas circulares," II5-I6, I39

"Tlön, Uqbar, Orbis Tertius," 4-5

Boscagli, Maurizia, I3

Bosch, Hieronymus, I4O

Bourdieu, Pierre, 45-46

Bradbury, Ray: Fahrenheit 45I, 2, I067, I2I-22

Braidotti, Rosi, II-I2, I4, I3I-32, I45, I48-49, I5I-52, I93

Broderick, Damien, 5, II-I2

Brown, J. Andrew, 194

Bruno, Giuliana, I75

Bruno, Paula, I7, 23

Bukatman, Scott, 106

Bunge, Carlos, I9

Buscarini, Juan Pablo. See Cóndor Crux, leyenda del futuro

Cabinet of Dr. Caligari, The, I73, I8I

Cain, 8, 56, 64-68, 202n2o

Cané, Miguel, 30

Capanna, Pablo, I-2, 6

capitalism, 9, II, I3, 82, 84, 89, IO5, I25,
I28, I57-58, I6I-62, I68, I70, I72-

75, I78-79, I84, I90-9I, I94-95

Cartwright, Lisa, I78

"Casa tomada," 90, 93

Cazaux, Diana, 23-24, 26-27

Chakrabarty, Dipesh, I55, I6I-62, I68, I70

chaos theory, IO, I34, I36-37, I39-40, I42

Christiansen, Hans-Christian, 5I

Cisneros, James, I76-77

city

in Benjamin's work, 8, 53-56, 60, 6465, 80, 92

representation of in comics and novels, 54-69, 80, 92

Ciudad, 8, 56-64, 66, 68, 74, 76ni3, 79, 202ni9

Clark, Andy, I24

Cohen, Marcelo, 6, II, I4, 49, I42-43, I52-53, I94, I96

Donde yo no estaba, 8, I32, I43, I47-5I

Variedades, 8, I32, I43-47

"cola de la serpiente, La," II

Colebrook, Claire, I46, I52

Cóndor Crux, leyenda del futuro, 6, II, I55, I62-70, I90-9I

Conti, Haroldo, 39-40

"Continuidad de los parques," 4

Coole, Diana, I32, I37

Coronil, Fernando, I6I

Cortázar, Julio, I29, I82

"Casa tomada," 90, 93

"Continuidad de los parques," 4

"La noche boca arriba," I34

"El otro cielo," 59

“Todos los fuegos el fuego," 208ni3

Crash Solomonoff, Pablo, I9-20

Crisis of 200I, 5, 83, 87-89, 91, IO5

cultural transmission, 8-9, 8I-88, 9396, 99-105, 107, 194

curas milagrosas del Doctor Aira, Las, 207n73 
Cruz diablo, 8-9, 82-84, 96-IO5, I9596

cyborgs, I24-25, I49, I94

Dabove, Juan Pablo, Ioo

Darwin, Charles

dissemination and reception of ideas in Argentina, 7, 16, 194-95

theory of evolution, 8-9, I2, I4, 27, $43,50,93,194-95$

See also Darwinism, social; Darwinist materialism; Post-Darwinism

Darwinism, social, I6, 82-83, 194

Darwinist materialism, 8, I2, 48

Daulte, Javier, 7, I32

4D Óptico, IO, I32-35, I4I

Automáticos, I34

de Ezcurra, Eduardo, I95

De Landa, Manuel, II, I43, 193

del Estal, Eduardo, I37

de los Ríos, Valeria, I29

Deleuze, Gilles, 37-38, I4I-43, I45-46, I49, I5I, I52-53, I92

Derrida, Jacques, 99, I29, I92

Dick, Philip K., 2, 156

dictatorship of $1976-83, \mathrm{I} 5,3 \mathrm{I}-32,42-$ 43, 5I, 53, 83, 9I, I32

Doane, Mary Ann, 187

Donde yo no estaba, 8, I32, I43, I47$5 \mathrm{I}$

Dos partidos en lucha, 26-27, I99n37

Drucaroff, Elsa, I-2, IO5

Dubatti, Jorge, I0, I36, I4I

Echeverría, Esteban, 90, 94

"embriones del violeta, Los," 4-5

"En memoria de Paulina," II5-I6

Enns, Jörn, 8, 53, 69

"espectro, El," IIO-I4

Estrellas, 6, II, I55, I57-62, I70, 190-9I, 195

Eternauta, El, 2, 7, 15-16, 3I-50

Evans, Arthur B., 25

"Eveline," 9I evolution. See Darwin; human evolution

Facundo, I00, 102

Fabrenheit 45I, 2, I06-7, I2I-22

Ferreira Haywood, Rachel, 20

Flammarion, Camille, I8, I98n4

Foucault, Michel, 37-38, 46-47, 98, 192

4D Óptico, Io, I32-35, I4I

Fractal, I37

fractal geometry, IO, I34, I37-38, I40

Fraser, Benjamin, 33

Frederick, Bonnie, 19-20

Freedman, Carl, 95, 155-57

Freud, Sigmund, I45, I64, I80-8I, I92, 209n53

Frondizi, Arturo, 36

Frost, Samantha, I32, I37

fuerzas extrañas, Las, 6, 93

Fukuyama, Francis, 8I-82, 88, IO4-5

"Fundación mítica de Buenos Aires," 90-9I

Gamerro, Carlos, I4I-42

Gandini, Carlos, I, 6

Gandolfo, Elvio E., I

García, José Mariano, I27

García, Martín, 200n83

García Canclini, Néstor, 56, 60-6I,

$$
\text { 63-64 }
$$

Gardner, Jared, 8, 53, 55, 68-69

Gasparini, Sandra, I7-I8, 20, 26

gene-culture coevolution, 9, I2, 50, 86, I24, I95-96

Generation of I880, I7-I8, 30

Gibson, William, I23, 212n67

Gilloch, Graeme, 55, 60, 80

Gilman, Claudia, 39

Giménez, Juan, 53

See also Ciudad

Glecer, Swan. See Cóndor Crux, leyenda del futuro

“Golem, El," I34 
Goligorsky, Eduardo: "La cola de la serpiente," II

Gorodischer, Angélica, I, 4-5 "Los embriones del violeta," 4-5

"Onomatopeya del ojo silencioso," 4

Gorriti, Juana Manuela: "Quien escucha su mal oye," 3

Groensteen, Thierry, 54

Grosz, Elizabeth, I8I

Grusin, Richard, I77, I79

guerra de los Antartes, La, 6

Gutiérrez, Eduardo, 99-I00

Hansen, Mark, I4, I92-93, 196

Haraway, Donna, II, I3I-32, I52

Harvey, David, I90-9I

Hayles, N. Katherine, 9-10

Heidegger, Martin, I92

Heise, Ursula, I82, I86

Heredia, María Florencia, I34, I4I

Hernández, Felisberto, I34

Hernández, Jose: Martín Fierro, I9, I02 historicism

Benjamin's critique of, II, I56-57, I70, I9I

as homogeneous, universal time of history, II, I05, I55-57, I60-62, I68, I70, I78-79, I90-9I, I95

historicity of science fiction, 82,95 , I55-57, I72-73

Holmberg, Eduardo Ladislao, 3, 7, 8, I5-3I, 48

Dos partidos en lucha, 26-27, I99n37

"Horacio Kalibang o los autómatas," 48-49

Olimpio Pitango de Monalia, 7, I6I7, 27-3I

"El ruiseñor y el artista," 49

Viaje maravilloso del señor Nic-Nac al planeta Marte, 6-7, I5-27, 2931, 47-49, I95, I99n37

"hombre artificial, El," 6

"Horacio Kalibang o los autómatas," 48-49
Horkheimer, Max, Io8

Hortensias, Las, $\mathrm{I} 34$

human evolution, 8-9, I2, 43, 48, 50, $82-88,93-96$, I04-5, I24-25, I94-95

Huyssen, Andreas, 70

idealism (philosophical), 4, 8, I2, 54, II5-I6, I34, I39

immigration, I5, I7-I8, 2I-22, 48, $9 \mathrm{I}$

imperialism, 3I-33, 42, 44, 89, I57, I60

indigenous culture, representation of, IO2-3, I63-67

“inmortal, El," I22

intellectual, role of in politics and relationship with masses, 7, I5-16, 3I-32, 35-4I, 43-48

intertextuality, 3, 5-6, 8, 52-53, 59-6I, 78, 89-93, 99-100, I27, 166

Invasión, 154

invención de Morel, La, 6, 9, IO7, II4-I9

Jameson, Fredric, I4

on postmodernity, I46, I56, I62, I66$68, \mathrm{I} 75, \mathrm{I} 84, \mathrm{I} 88$

on science fiction, I55-56, I60, I7I$73,183-84,189$

"jardín de senderos que se bifurcan, El," 73

Jauretche, Arturo, 45

James, Ian, 95, I30-3I, 193

Jenkins, Henry, I77

Joyce, James, 9I, I82, 204n25

juego de los mundos, El, 9-IO, IO8, II930, 194,196

Kardec, Allan, I8

Keightley, Emily, I87-89

King, Edward, 99-100

Kirchner, Néstor, 47

Kriger, Clara, 159

Kuntscher, Leonardo. See under Viaje maravilloso del señor Nic-Nac al planeta Marte 
Lacan, Jacques, 192

Laera, Alejandra, 24

Landsberg, Alison, I86, 190

Latinoamérica y el imperialismo: 450 años de guerra, 44

Latour, Bruno, I67, I69-70

La Valley, Albert, I83

Le Bon, Gustave, 28

León, Federico. See Estrellas

Léroi-Gourhan, André, 9, 86

Levine, Alex, I94-95

Lim, Bliss Cua, I55, I68

linguistic constructionism, 4-5, IO-I2, I4, 52-53, I32, I36, I4O, I42, I52, 193

linguistic turn. See linguistic constructionism

Lugones, Leopoldo, I, I29 Las fuerzas extrañas, 6, 93

"Yzur," 93

Lukács, Georg, 95, I56

Mairal, Pedro, I4

El año del desierto, 8-9, 82-84, 8896, 104-5, 194-95

Malabou, Catherine, IO, I4, I08, I25-3I, 193-94, 196

Manovich, Lev, I69

Martínez, Marcos. See Estrellas

Martínez Estrada, Ezequiel, 90

Martín Fierro, I9, IO2

Marx, Karl: relationship between human labor, nature, and technology, I2-I3, I6, 50, I94

Marxist criticism, I3-I4, I45-46, I55-56, I9I

Marxist historicism, I6I-62, I89

Marxist materialism 8, II-I2

masses

education of the, 7, I6-I7, 20, 29-30, 34-35. See also popular dissemination of science governance of the, $7,17,20-2 \mathrm{I}, 28$ 3I relationship with intellectuals. See intellectual

McCloud, Scott, 54

McLuhan, Marshall, Io

McQuire, Scott, I57

media convergence, I77-78

See also remediation

metabolism, I2-I3, I49-50

metafiction, 3-4, 8, I2, I4, 50, 54, I32$36,138,192$

See also reflexivity

Meteling, Arno, 54-55

Metropolis, I73-74, I79

militancy (left-wing) of I970s, I5, 3I-32, 37, 39-42, 44, 96

Ministerio, 8, 5I, 52f, 56, 62, 70-7I, 74, 76-77, 20InI

mnemotechnics, 98-99, I04

modernity

critique of in comics, 54-56, 60-66, 80

conceived as linear development, II, 83-84, I05, I55, I57, I6I-62, I66, I70, I84, I90-9I

modernizing project of the Generation of 1880 , I5-20, 23-3I

Moebius, I54

"mono que asesinó, El," 6, 93

montoneros, 3I-32, 40, 42, 44, 96,

I99n 54

Moore, Gerald, I95

Morin, Edgar, IIO, II4, II8-I9

Mosquera R., Gustavo, I54

national identity, I5, 2I-23, 48, 97

nationalism, 27, 30, 36, I02

neocolonialism, 6, 32, 44, 47, I6I

neoliberalism, 9, I4, 56, 64-66, 87, I25, I63, 202n39

Neuromancer, I23

Nietzsche, Friedrich, I49, 209n53

"noche boca arriba, La," I34

Nora, Pierre, 70 
Novoa, Adriana, 194-95

Nowotny, Helen, I86

Nitsch, Wolfram, II7

new materialism, IO-I4, 79, I3I-32, I36, I $42-43$

Oesterheld, H. G., 8, 53, 77, I94, I99n 54, 202n 40

El Eternauta, 2, 7, I5-I6, 3I-50

La guerra de los Antartes, 6

Latinoamérica y el imperialismo: 450 años de guerra, 44

Olimpio Pitango de Monalia, 7, I6-I7, 27-3I

"Onomatopeya del ojo silencioso," 4 “otro cielo, El,” 59

Pagés Larraya, Antonio, I9

paranoia, La, IO, I32, I34-42, I52-53

Parque Chas, 78

Parrinder, Patrick, 88

Pérez Rasetti, Carlos, i8

Perón, Juan Domingo, 36, 42-43

Peronism, 3I-32, 36, 38-39, 47, I99n54

Perramus, 59

pharmakon, technology as, 99, I04

Piglia, Ricardo, I82, 20In4

Pfister, Manuel, 52

Pinedo, Rafael, 6

Plop, 8, 82-88, 95, I04-5, I95, 203ns

plasticity, IO, I08, I2O, I24-3I, I93, I96

Plop, 8, 82-88, 95, I04-5, I95, 203ns

popular dissemination of science, 16 , 2O-2I, 23-27, 29-30, 35, 70

positivism, $16,28,49$

postanthropocentrism, I32, I36, I52

"Post-Bombum," 8I

postcolonialism, 6, II, I57

Post-Darwinism, 9, 50, 93-94, I94-95

posthumanism, 2, 5, I2, 49, I37, I42, I48, I50-51, I94, 196

postmodernism, 8 , II, 52-54, 73, 80, II4, I46, I52, I56, I66, I72-73, I80, I82, I86, I89-90

postmodernity, 63-64, I62, I67, I75, I84, I88 prosthesis, II, 66, 95, I47-48, IOO, IO34, I47-48, I86, I94, I96

literature as, 9-IO, IO7-8, I2O, I23-

24

psychopower, 98

“puritano, El," IIO-II, II3

Quereilhac, Soledad, 48

Quesada, Vicente, 30

"Quien escucha su mal oye," 3

Quiroga, Horacio, 9, 93, I07-I6, I283I, 196

"El espectro," IIo-I4

"El hombre artificial," 6

"El mono que asesinó,” 6, 93

"El puritano," IIO-II, II3

"El vampiro," IIO-I3

Rancière, Jacques, I43, I45-46, I53

Ramos Mejía, José María, 28

Reading, Anna, I87-89

Reati, Fernando, 5

reflexivity, 3-8, II-I2, 36-38, 40-4I, $46-48,51,53,66,69,73-76,80-$ 8I, I55, I57, I60, I70-72, I80, I85, I89-92

See also metafiction

remediation, 8, 52, I77, I79

See also media convergence

retrofuturism, I55, I72-73, I75, I79-80, I85

Risso, Eduardo, 53

See also Cain; Parque Chas

Rocca, Pablo, in2Rodríguez Pérsico, Adriana, I7, 29

Rosen, Philip, I69

"ruinas circulares, Las," II5-I6, I39

“ruiseñor y el artista, El," 49

Santiago, Hugo, I54

Sapir, Esteban. See La antena

Sarlo, Beatriz, 35, 44, III-I3

Sarmiento, Domingo Faustino, 16, 22, 90, 93, 100-102

Sartre, Jean-Paul, 7, 36

Sasturain, Juan, 32, 59 
science, popular dissemination of. See popular dissemination of science Scott, Ridley. See Blade Runner

Semilla Durán, María A., 89, 9I-93, 204nI9

Serres, Michel, I67, I69-70, I84

Sigal, Silvia, 36, 45, $200 n 67$

Simmel, Georg, 56

Simondon, Gilbert, 205n46

Sinnerbrink, Robert, 196

Slot-Barr, 8, 69, 7I-73, 77-79, 202n45

Solano López, Francisco, 53

See also El Eternauta; Ministerio;

Slot-Barr

sonámbula, La, 6, II, I3, I7I-72, I79-9I, 196, 212n76

Spiner, Fernando: Adiós querida luna, I 54

See also La sonámbula

Spinoza, Baruch, I49

spiritism, 8, I8, 48

Spregelburd, Rafael, 7, IO, I32, 194

Fractal, 137

La paranoia, IO, I32, I34-42, I52-53

Sterelny, Kim, 85-86, I24-25

Stewart, Garrett, I89

Stiegler, Bernard, I4, 97, 193-94, $205 \mathrm{n} 46$

on gene-culture coevolution, 9, 50,

I24, 195-96

on psychopower, 98

on technics, I2, 82-84, 86, 93-95, I04-5, IO8

on technology as pharmakon, 99, IO4

on time and technics in cinema, 155 , I85-87, 213n86

Suhr, André, 53-55

Suvin, Darko, I57

temporality

as shaped by technics, I4, IO4-5

in cinema, II, I55, I8O-90 linear temporality of modernity. See under modernity

polytemporality in the Latin American context, 56, 63-64, 96-97

polytemporality of technology, I67, I69-70

Terán, Oscar, 30, 36, 38-39, 45

technics, I2, 82-84, 86, 93-95, IO4-5, Io8

“Tlön, Uqbar, Orbis Tertius," 4-5

"Todos los fuegos el fuego," $208 \mathrm{nI} 3$

time, social experience of, I87-89

utopia, 7, I7, 27-28, 30, 50, I05, I60, I63, I7I-74, I79, I84, I89-9I, I96

Valentin, $\mathrm{I} 54$

"vampiro, El," IIO-I3

Vanasco, Alberto, 8I

Variedades, 8, I32, I43-47

Verne, Jules, I8, 23, 25, 29

Viaje maravilloso del señor Nic-Nac al planeta Marte

by Holmberg. See under Holmberg,

Eduardo Ladislao

by Kuntscher and Miret, 47-48

Virilio, Paul, I3

Von Sprecher, Roberto, 40-4I

Vonnegut, Kurt, 59

War of the Worlds, The, 2, 157, I60

Waugh, Patricia, 3

Wells, H. G., 25, I99n37

The War of the Worlds, 2, 157, I60

Wilde, Eduardo, I9

Williamson, Al, 73-74

Wolfe, Gary K., 63

"Yzur," 93

Zanotto, Juan, 53

Zimmer, Zac, 87, 89, 203ns 
